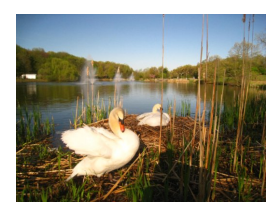

Western Michigan University Medieval Institute Publications/Arc Humanities Press

\title{
Shakespeare, Antony and Cleopatra, and the Nature of Fame
}

Robert A. Logan

University of Hartford, logan@hartford.edu

Follow this and additional works at: https://scholarworks.wmich.edu/mip_rmemc

Part of the Literature in English, British Isles Commons, and the Modern Literature Commons

\section{Recommended Citation}

Logan, Robert A., "Shakespeare, Antony and Cleopatra, and the Nature of Fame" (2018). Research in Medieval and Early Modern Culture. 4.

https://scholarworks.wmich.edu/mip_rmemc/4

This Monograph is brought to you for free and open access by the Medieval Institute Publications at ScholarWorks at WMU. It has been accepted for inclusion in Research in Medieval and Early Modern Culture by an authorized administrator of ScholarWorks at WMU. For more information, please contact wmuscholarworks@wmich.edu.

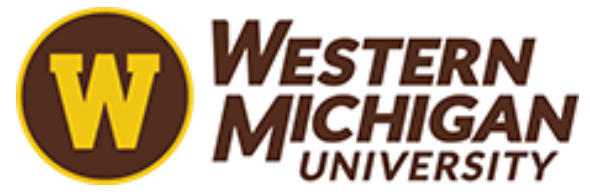




\section{Shakespeare, Antony and Cleopatra, and the Nature of Fame}

Robert A. Logan

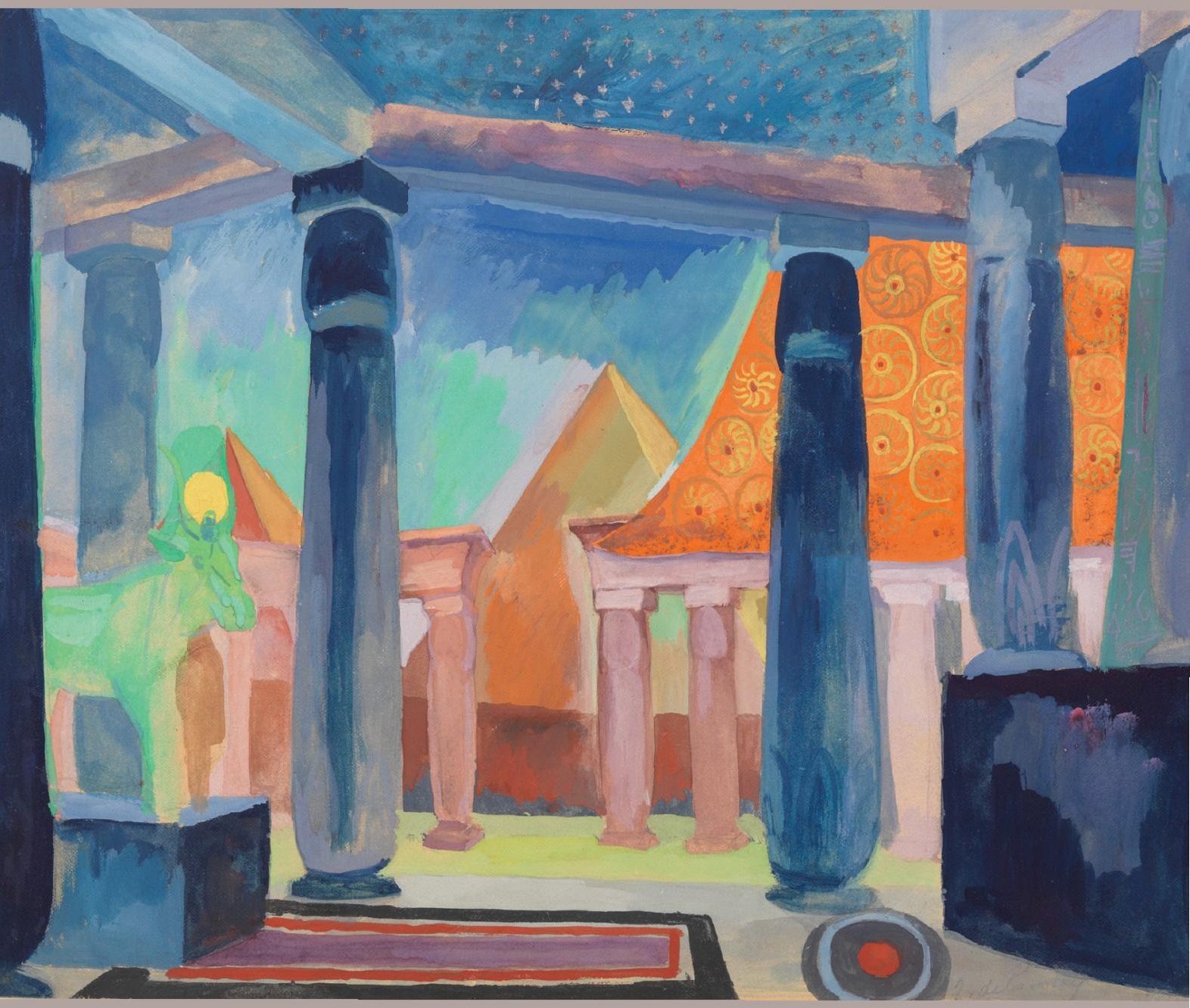


Shakespeare, Antony and Cleopatra, and the Nature of Fame 
RESEARCH IN MEDIEVAL AND EARLY MODERN CULTURE

Medieval Institute Publications is a program of The Medieval Institute, College of Arts and Sciences 


\title{
Shakespeare, Antony and Cleopatra, and the Nature of Fame
}

by

\author{
Robert A. Logan
}

Research in Medieval and Early Modern Culture

MEDIEVAL INSTITUTE PUBLICATIONS

Western Michigan University

Kalamazoo 
Copyright (C) 2017 by the Board of Trustees of Western Michigan University

Library of Congress Cataloging-in-Publication Data

Names: Logan, Robert A., 1935- author.

Title: Shakespeare, Antony and Cleopatra, and the nature of fame / Robert A. Logan.

Description: Kalamazoo : Medieval Institute Publications, [2018] | Series: Research in Medieval and Early Modern culture | Includes bibliographical references and index.

Identifiers: LCCN 2017046070 | ISBN 9781580443197 (hardback : alk. paper)

Subjects: LCSH: Shakespeare, William, 1564-1616. Antony and Cleopatra. | Shakespeare, William, 1564-1616--Characters. | Fame in literature.

Classification: LCC PR2802 .L64 2018 | DDC 822.3/3--dc23

LC record available at https://lccn.loc.gov/2017046070

ISBN: 9781580443197

eISBN: 9781580443203

All rights reserved. Without limiting the rights under copyright reserved above, no part of this book may be reproduced, stored in, or introduced into a retrieval system, or transmitted, in any form, or by any means (electronic, mechanical, photocopying, recording or otherwise) without the written permission of both the copyright owner and the author of the book.

Every effort has been made to obtain permission to use all copyrighted illustrations reproduced in this book. Nonetheless, whosoever believes to have rights to this material is advised to contact the publisher. 
To John J. Wright for his immeasurable "bounty" 



\section{Contents}

Acknowledgments $\quad$ ix

1 Introduction: Viewing Shakespeare's Kinetic 1

Characterizations

2 Antony and Cleopatra in Seventeenth-Century 17 Contexts

3 "Immortal Longings": Shakespeare's Perspective 31 on Fame

4 Standards of Measure in Antony and Cleopatra 53

5 "The Varying Shore": Changing Perceptions, 93 Sustaining Illustriousness

6 "A Pair So Famous": Achieving Permanent Renown 125

7 Shakespeare’s Imperishable Fame 155

$\begin{array}{ll}\text { Bibliography and Further Reading } & 181\end{array}$

$\begin{array}{ll}\text { Index } & 189\end{array}$ 



\section{Acknowledgments}

MPOSSIBLE AS IT IS to acknowledge the many influences of scholarly publications, conference sessions, and classroom experiences on my understanding of Antony and Cleopatra, three people who have contributed either directly or indirectly or both to the following book must be mentioned. To Sara Munson Deats, I owe a career-long debt of gratitude, but am specifically grateful to her for commenting on a draft version of the manuscript with such care, rigor, and astute suggestions. To Erika Gaffney, a senior editor who has guided me wisely in more than one publication, I am most grateful. Her candor, detailed suggestions, and high standards are exemplary and inspiring; as editors go, she stands out as an exceptionally superior role model. Finally, to my husband and champion, John Wright, I am thankful beyond my ability to express the depth of my gratitude. His unfailing desire to free up my time and give encouragement have displayed a magnanimity that even Antony could not match. I am truly honored to have had these three people in my life over the years but especially during the current project. 



\section{Chapter 1}

\section{Introduction: Viewing Shakespeare's Kinetic Characterizations}

SO MUCH HAS BEEN written about the life and works of William Shakespeare that a new monograph on Antony and Cleopatra, one of the playwright's most controversial works, might well begin with a discussion of how it marks an advance over both longstanding and recent criticism in subject matter, structure, and focus, including some explanation of why it approaches the play from diverse vantage points. I should note first that, in reviewing the scholarship on Antony and Cleopatra, I found that the flow of criticism has been relatively less since the turn of the twenty-first century than it was during the second half of the twentieth century. The most penetrating criticism began to emerge in the nineteenth century (e.g., Coleridge and, on Shakespeare more generally but applicable to this play, Keats) and reached its strongest and most fecund period in the twentieth century (e.g., Adelman, Barroll, Bevington, Bradley, Brower, Charnes, Charney, Danby, Knight, Macdonald, Mack, Markels, Neill, Spevack, Wilson). The Modern Language Association Bibliography lists 304 entries of articles, book chapters, and books written between 2000 and 2016. Of the five books listed, none bears on the subjects of the present study: Shakespeare's imaginative portrayals of internationally famous historical figures as they measure up to self-standards of conduct and understand their relation to imperishable fame. Nor has previous criticism applied in a concentrated manner these subjects to Shakespeare and to this play. My contention is that Antony and Cleopatra reflects the playwright's understanding of and fascination with the nature of fame more completely than any of his other works.

Marvin Rosenberg's The Masks of Anthony and Cleopatra, edited and completed posthumously by his wife in $2006,{ }^{1}$ does a scene-by-scene discussion of the play, focusing on performance, but by dividing the "viewers and readers" (10) of the play into yay sayers and nay sayers imposes unnecessary limitations on its observations. So far during this century, the only collection of essays on the play, edited by Sara Munson Deats and 
entitled Antony and Cleopatra: New Critical Essays, appeared in 2005. ${ }^{2}$ Deats finds the play to be Shakespeare's "most anamorphic drama" (1) and hopes that the "original essays written for this anthology ... will significantly expand the critical contexts within which [the play] can be read, viewed, and analyzed" (ix). Deats's introductory essay surveys criticism on the play and its performances on the stage and screen, while the essays in the collection range in approaches and in topics, covering new ground even when the subjects are familiar-e.g., sources, influences, the import of the conflict between Egypt and Rome, stagings of the play.

I have not discovered any articles that concern themselves with the combination of subjects, diversity of foci, and the methodological variations of the present study. Interestingly, since the turn of the century, the field of commentary on the play has not been overcrowded. The present study of the play's heightened emphasis on standards of measure and their connection to fame has never been the major focus of a book or any of the articles that I have come across, especially given the present mix of approaches. The importance of fame as a subject for scholarly study was thrust into the spotlight in October, 2011 when the Publications of the Modern Language Association (PMLA) devoted an entire issue to "Celebrity, Fame, Notoriety" (Vol. 126, No. 4). Without treating Antony and Cleopatra specifically, the issue gave imposing support to my efforts, already well underway, to address this overlooked topic, covering not only a wide range of articles on the celebrityhood of actual and fictional figures but also including a section on theories and methodologies. Most of what has been written about this topic has been in the form of a sociological study. The PMLA issue makes clear that there is a need for literary studies on the topic, making use of sociological findings of course; the issue further suggests that the subject invites close reading, an approach that has not been tried with literary texts. ${ }^{3}$ Apart from Julius Caesar, Antony and Cleopatra have a more longstanding and renowned fame than any of the other historical characters in Shakespeare's plays. Thus, to address Shakespeare's concern with the nature of fame, this play, rather than his other Roman works ${ }^{4}$ or his English histories, has from the outset seemed the perfect choice.

In an attempt to open up different avenues to Shakespeare's Antony and Cleopatra, my intention has always been to approach the play from several interpretive perspectives rather than from just one. Whereas the characterological, historical, cultural, and textually analytical perspectives employed here are familiar individually, as is the notion of a combination, 
I believe that this combination provides a distinctiveness that is without precedent. The overall movement of the book is from external groundwork concerns to a close reading of the play, mindful that such a reading needs always to be related to the main subjects-the constantly shifting complex of portrayals of standards of measure and their relation to the establishment of the imperishable fame of Shakespeare's protagonists, as distinguished from their mere celebrityhood. The study closes with an examination of the reasons for Shakespeare's fame, including a brief history of its progress, and the parallels between the attributes of fame in the play and the attributes of his fame.

More specifically, the external groundwork begins with my contribution to the centuries-old discussion of how to read dramatized figures; this characterological discussion attempts to offer a fresh perspective that pertains not only to characters in Antony and Cleopatra but also in Shakespeare's other plays and in those of his contemporaries. The second chapter seeks to place the play historically in seventeenth-century contexts, including the theater culture of which Shakespeare was a significant part. The chapter pays attention to contexts that the playwright both regarded and disregarded as he composed and (presumably) first staged the play. My prevailing sense is that not enough has been said about how non-topical the play is and, ultimately, why a more strictly conventional or early modern historical lens in examining the play yields so little. The following chapter discusses the notion of fame, its origins, Shakespeare's definition of it, and my understanding of the playwright's views on fame, specifically, but not exclusively, as they pertain to the renowned dramatis personae of Antony and Cleopatra. The ideas here can also be applied to Shakespeare's other Roman works, to his history plays, and to the plays of his contemporaries.

The next three chapters feature a close textual analysis of those sections of the play that best elucidate the concern with the interweaving of standards of measure and fame, as well as issues that they raise (e.g., Shakespeare's view of "honor"). What is different from the earliest versions of this approach is that here the close reading is embedded in the knowledge of the chapters that precede it. Consequently, the three chapters offer readings that I have not seen in print and, I hope, provide ways to read anew several key passages in the play. Extensive close analysis of the text has been missing from the most recent critical commentary on the play. One important feature of this method is that it enables readers not only to better scrutinize and understand the text, but to draw some 
conclusions about the imagination and artistic reasoning behind it without an undue emphasis on thematic considerations and without being burdened by restrictive perspectives of critical theory. To be sure, close reading is itself a theory but a theory rooted in the pragmatics of the text. If one asks why this method is especially important for this play, one answer lies in the well-commented-upon, staggering number of ambivalences and ambiguities in language, characterization, and events. ${ }^{5}$ Close analysis enables readers to confront the difficulties of the ambivalences and ambiguities and, by understanding them as a conscious dramaturgical technique, may suggest some ways of integrating them into an understanding of the play and intensifying a viewer or reader's engagement. Too little attention has been paid to ambiguity as a conscious artistic device used by Shakespeare and his fellow contemporary dramatists.

The final chapter focuses on the nature of Shakespeare's fame, how it came about, and what it has come to be in our own time with some indication of what its future will be. It closes with a discussion of the links between the playwright's dramatization of standards of measure and fame in Antony and Cleopatra and his own standards and fame. Although not its purpose, the conclusion gives one more indication of why we find Shakespeare's relevance today such an accurate truism.

Deliberately excluded from the book is a discussion of performances of the play. Chiefly among several others, Spevack in his variorum edition of the play (1990), Deats in the introduction and some of the essays in her edition of collected essays (2005), Bevington in the introduction to his edition of the play (2005), Rosenberg in his book (2006), and the constant reviews in journals such as the Shakespeare Quarterly indicate the increasing popularity of this topic among scholars and, of course, each new performance receives reviews of theater critics. As a result, commentary on performances hardly needs retracing here, especially since I am chiefly concerned with what the written text yields. Also excluded are subjects that I have covered in previous published works (e.g., on Shakespeare's sources and influences), although, where appropriate, I have referred to these writings in footnotes. The study of Antony and Cleopatra has been for me a challenging and exhilarating lifelong process, not a recent discovery. I am only too happy to offer what I believe are some new ways of understanding and enjoying the imaginative riches of this superlative text.

In the introduction to her collection of essays on Antony and Cleopatra, ${ }^{6}$ Sara Deats delineates the tendency of commentators as early as the seventeenth century and down through the ages to embrace with 
determined steadfastness a single categorical perspective on the play. Deats pinpoints the three most popular stances, declaring that scholars and critics have traditionally either exalted or condemned the lovers but that, more recently, there has emerged a less rigid, wiser tendency to reject these two choices and, instead, to concentrate on the web of ambivalence and ambiguity that encompasses the characters, action, and language of the drama. In effect, however, the practice of expressing an allegiance to a particular, restricted approach or focus still obtains and even predominates. Not surprisingly, this tendency has created intense controversy among those who have offered opposing interpretations of the play. ${ }^{7}$

Understandably, the advantage of a single-minded perspective is that we are able to categorize our all-too-numerous impressions of the text, complicated and made difficult by the many ambivalences and ambiguities. Of course, we naturally desire to give order to such impressions, because the process enables us to sort them out and acquire some sense of control over them. But the categorizing of our impressions also runs the risk of reductionism and, concomitantly, oversimplification, a result of the limits on our critical perspective; this risk can, in turn, cause the authenticity and effectiveness of the classification itself to be called into question. Because of the ambivalences and ambiguities of Antony and Cleopatra, the desire to sort through our impressions and to categorize them seems all the more reasonable, even necessary. Ideally, a more desirable route would be a flexible weaving together of several, diverse, shifting critical perspectives. But the complexities and difficulties of this route can be insurmountable. The following generalized discussion of Shakespeare's kinetic characterizations, seen from the mutual perspective of the playwright and his viewing and reading audiences, exemplifies the difficulties an attempt at such inclusiveness can entail. ${ }^{8}$ For obvious reasons, the discussion is not limited to Antony and Cleopatra.

As I have come to understand Shakespeare's characterizations, there are four types of figures to be found in his plays. They can be designated as: Realistic, Representational, Functional, Authorial, Metadramatic. ${ }^{9}$ To understand the two fundamental categories of response on which these types are predicated (yes, "categories"), it is helpful to use the playwright's own distinction in A Midsummer Night's Dream (5.1.5-6 and 19-20) ${ }^{10}$ between "apprehending" and "comprehending" states of mind-that is, between an involuntary, unself-conscious, non-rational, intuitive, emotional response ("apprehending") and a voluntary, self-conscious, rational, 
thinking response that arrives at judgments through logical, empirical, analytical reasoning ("comprehending"). Overriding both states of mind for theatergoers, of course, is some degree of awareness that we are at a theater watching actors portray characters that, as fictional creations, are subject to controls different from ours. For readers, there is, inevitably, a similar overriding sense-in this case, that we are experiencing the actions of fictional figures at a pace, which, unlike that of theatergoers, we are able to control. Readers can pause to reflect, disconnecting from an emotional engagement with characters and their actions. Even so, when, as spectators or readers, we "apprehend" characters, it is for their traits as realistically individualized personalities; we do so spontaneously, and, in its ideal, purest form, with an imaginative projection and complete involvement that leave no room for intellection. When, with similar single-mindedness, we "comprehend" characters, it is for their significance or function in the drama, and we do so voluntarily, using our rational faculties and reflective powers with a detached critical awareness. We are able to project ourselves into characters and, either simultaneously or in close succession, remain critically detached from them, but, of course, in such a case we can do neither fully. Furthermore, our strongest natural impulse in responding is to "apprehend" or identify ${ }^{11}$ with characters, to lose ourselves in them by looking at their world with their eyes; if, instead, we "comprehend" them, it is because the playwright has used some artistic means to suppress our intuitive impulse and produce in us a sense of self-conscious detachment.

These distinctions indicate that the four types of characters may be more accurately perceived as four patterns of psychological response:

(1) If we say that we have responded to characters as Realistic figures, we mean that to some degree we have projected imaginatively into them with immediacy and, in a spontaneous, intuitive acknowledgment of a psychological reality as we experience it outside the play, have "apprehended" them as plausibly individualized. This involuntary response depends upon our ability to link the psychological behavior of the characters with a familiar pattern of human psychological behavior; it occurs only when the characters' actions within a given situation conform to the specific conditions of their personalities and are in accordance with those of the situation. In Antony and Cleopatra, there are times when we readily identify with Antony in his anguish at feeling torn between two contradictory cultural schemes loosely characterized as Egyptian and Roman 
values. The first such occurrence takes place when a messenger comes to tell the triumvir of events in Rome:

Messenger: News, my good lord, from Rome

Antony: Grates me! The sum

Cleopatra: Nay, hear them Antony.

(1.1.18-20)

But Antony does not. He does listen to the next messenger, however, who tells him of his brother and his wife Fulvia's attacks on Caesar, Labienus's victories, and soon after to a fourth messenger ${ }^{12}$ who blurts out nervously that Fulvia has died (1.2.83-118). Stricken with guilt at what has taken place during his inattentive absence, Antony calls upon Enobarbus to prepare for their immediate departure from Egypt (1.2.128-90). But we know that this is not a permanent solution to the conflict within him. Another example: When Coriolanus accedes to his mother's plea to spare Rome (Coriolanus 5.3), we are able to be absorbed instantly, first, because, given our understanding of the potency of mother-son relationships outside the play, we recognize that he acts with psychological plausibility; secondly, he acts in accordance with the conditions of his personality as they have already been established within the play-especially, his close emotional ties to his mother. If in reply to his mother, Coriolanus had remained unmoved, we may well have been too puzzled by the sudden illogic of his behavior to respond to him with intuitive immediacy and, therefore, would have tried to understand his behavior through rational reflection, a state that requires some detachment.

(2) If we say that we have responded to characters as Representational figures, we mean that we have, with detachment, "comprehended" them, not as psychologically individualized figures but as representations made emblematic (a term indicating a moral position) or symbolic (a term indicating that no moral position has been established). Cordelia, set in opposition to Goneril and Regan, and Desdemona, set in opposition to Iago, are readily identifiable as moral emblems, just as in Richard II the Duke of York is a non-moralizing symbol of divided loyalties. In Antony and Cleopatra, the Soothsayer is symbolic of the irrevocable dictates of Fate; we do not know why he is in Rome with Antony (2.3.10-31), but the fact that he is suggests that Shakespeare wants us to focus on his presence as symbolic. The Soothsayer reveals the truths of ultimate reality without taking a moral position but then, enigmatically, encourages Antony to remove himself from the presence of Caesar (2.3.10-30) so 
that his "spirit" (2.3.18), away from Caesar, can thrive. The details of this scene follow closely the details in Plutarch's account. Given the demands of Antony's present political responsibilities, it is not clear where the triumvir would go or what he would do, especially since the Soothsayer laments that Antony ever set foot in Egypt: "Would I had never come from thence [Egypt], nor you thither" (2.3.10; my italics). The ambiguities surrounding the Soothsayer's presence and some of his revelations force us to concentrate on him as a symbolic representation of the mysterious workings of Fate rather than as either a realistic or morally emblematic character.

(3) If we say that we have responded to characters as Functional figures, we mean that we have "comprehended" them as devices of dramaturgy, rather than for their significance as realistically individualized or representational figures. Characters used primarily as dramatic devices may be either practical necessities or arbitrary presences. The numerous messengers in Antony and Cleopatra are examples of practical necessities. The boy in Much Ado About Nothing (2.3), who keeps Benedick in the orchard by never returning with the book that he was sent for, exemplifies a figure of another type of practical necessity. In general, those minor characters, often silent, whose presence contributes to the plot or mood, even if only as part of the visual effect, function as arbitrary presences. In Antony and Cleopatra, the eunuchs and other court figures at Alexandria, especially in Antony's and Cleopatra's first appearance (1.1.10), act as arbitrary presences, giving us a visual sense of the exotic luxuriousness of the Egyptian court. The use of functional characters who are major as well as minor becomes clear if we remember Octavius's praise of Antony (1.4.5672) and Enobarbus's of Cleopatra (2.2.189-250), or Shakespeare's use of Goneril and Regan to characterize the King's temperament, past and present, at the end of the first scene of King Lear (1.1.289-312).

Antony and Cleopatra's Octavia operates complexly as both a representational and a functional figure. As a representational figure, she is a puppet of Roman political manipulation, a submissive victim of divided loyalties who enables us to resent the nasty consequences of the workings of sociopolitical forces, inevitable and omnipotent though they are. Rather than an effective mediator, Octavia is an example of the "food" Enobarbus mentions in his grim reflection on the demise of Pompey: "world, thou hast a pair of chaps, no more; / And throw between them all the food thou has, / They'll grind the one the other" (3.5.11-13). About Octavia John Danby rightly asserts, "There is nothing in her as a 'charac- 
ter-study' to account for the effect her presence has. It is rather that she is transparent to the reality behind the play and one of its least mistakable mediators." ${ }^{13}$ In one of her functional roles, she helps to make the contention between Antony and Octavius seem a truly epic struggle; she tells her husband that "Wars 'twixt you twain would be / As if the world should cleave, and that slain men / Should solder up the rift" (3.4.30-32; my italics). In a second functional role, she presents a contrast with Cleopatra. Maecenas describes her "beauty, wisdom, modesty" (2.2.251) and, in pointed contrast to Cleopatra, Enobarbus claims that "Octavia is of a holy, cold, and still conversation" (2.6.120). Cleopatra herself later angrily tells Proculeius, "Know, sir, that I / Will not wait pinioned at your master's court, / Nor once be chastised with the sober eye / Of dull Octavia" (5.2.51-54). It is clear that Shakespeare wishes us to see that in temperament Cleopatra is everything that Octavia is not and that that is why Antony "will to his Egyptian dish again" (2.6.123). Yet, as much as the contrast inclines us to be awed by the personality of the Queen and even admire it, we do not judge Octavia harshly, partly because she is a helpless pawn within her political context and partly because we are only slightly invited to respond to her as a realistic figure-in Act 3, Scene 4 where she expresses anguish at the division between her husband and brother: "A more unhappy lady, / If this division chance, ne'er stood between, / Praying for both parts" (11. 12-14).

(4) If we say that we have responded to characters as Authorial (or Metadramatic) figures, we mean that we have "apprehended" them as the voice of Shakespeare, who, momentarily, is unwilling to suppress a personal notion or to refrain from indulging in a display of verbal ingenuity. What usually enables us to recognize an authorial figure is the sense that the content or style of the character's words has roots in something other than the immediate situation. Sometimes, the intrusiveness of disproportionate generalizing or an incongruously heightened style alerts us to the voice of the author. An example of the former occurs at the beginning of Act 5 of $A$ Midsummer Night's Dream just after Hippolyta muses on the strangeness of the lovers' tales. Her evident fascination touches off Theseus' well-known set speech on the transforming powers of the "imagination" (5.1.2-22). As the voice of hardheaded rationality, Theseus doubts the truth of the imagination, whether it be that of the lover, the lunatic, or the poet. Thus he opens on an ironic note that he sustains as he links the fantasies of the lovers with those of madmen (11.2-11). ${ }^{14}$ But when he moves on to describe the powers of the imagination in the poet, 
whom Shakespeare has irrelevantly included in the comparison, the tone becomes clearly less skeptical (11. 12-17); logically, Theseus cannot be praising these powers, but a note of admiration seems to creep into his voice nevertheless. Moreover, for all its extraneousness, this section on the poet is lengthier than those on the lunatic and the lover and, seen from the viewpoint of the "poet" of this play, noticeably self-reflective:

And as imagination bodies forth

The forms of things unknown, the poet's pen

Turns them to shapes, and gives to airy nothing

A local habitation and a name.

$(5.1 .14-17)$

Up to this point in the play, the "things unknown" have been the function and power of the imagination in love, including its abuses; to them Shakespeare has given both "a local habitation and a name." In the remainder of the play, he will go on to deal with "things unknown" by dramatizing the powers, functions, and abuses of the imagination in art, specifically drama. This intrusive section serves as an anticipatory signpost, ${ }^{15}$ and the entire speech as an authorial commentary, directing us to the play's symbolic meaning: the imagination as a way of knowing. In effect, this speech also explains why the play continues for another act after the plot has been concluded. Hippolyta's reply to Theseus (11. 23-27), the final word on the subject, affirms the playwright's special regard for the truth of the imagination, "howsoever, strange and admirable" (27) its products; she finds that Theseus' rational view is inadequate, and the implication is that we should too.

Examples of Shakespeare's often exuberant displays of verbal ingenuity strike us either when several characters speak with the same depersonalized cleverness (e.g., in Love's Labor's Lost and Richard II) or when a character speaks out of character, as Lady Capulet does in developing the metaphor of Paris as a book (Romeo and Juliet 1.3.81-94), and as Capulet does in extending an invitation to Paris:

This night I hold an old accustomed feast,

Whereto I have invited many a guest,

Such as I love; and you among the store,

One more, most welcome, makes my number more.

At my poor house look to behold this night

Earth-treading stars that make dark heaven light.

Such comfort as do lusty young men feel 


\begin{abstract}
When well-appareled April on the heel Of limping winter treads, even such delight Among fresh fennel buds shall you this night Inherit at my house. Hear all, all see, And like her most whose merit most shall be; Which, on more view of many, mine, being one, May stand in number, though in reck'ning none.

(Romeo and Juliet 1.2.20-33)
\end{abstract}

The intensely romantic, conceited style and the enthusiastic couplet rhythms of lines 24-30 make clear that, when it comes to games with words (to rework Samuel Johnson's well-known pronouncement), the pun is not Shakespeare's only "fatal Cleopatra."16

I have already noted that complete imaginative projection into characters makes it impossible to remain critically detached from them. The reverse may also be true. But neither projection nor detachment eliminates the possibility that characters may simultaneously elicit both kinds of response. This likelihood means that one is able to respond to characters in more than one way, but often not at the same time-as, for example, when our emotional involvement is so complete that it blocks our rational ability to reflect. Frequently, characters are not simply Realistic, Representational, Functional, or Authorial, but a combination of these types, as the above example of Octavia suggests. Further, the combination may change during the course of a play, making it virtually impossible for us to set the dials of our response; and with several interacting characters, the difficulties multiply. Antony and Cleopatra reaches the outer limits of this tendency in its multiplicity of characters, events, and scenes, coupled with a hectic pace that slows down only at the suicides of the two chief protagonists. One further complication is the instability of our response or focus, our constant flicking back and forth between emotional and thinking responses. Although, understandably, these are problems often overlooked by critics, they nevertheless help to explain the feelings of inadequacy that spectators and readers have experienced in trying to respond with completeness to Shakespeare's kinetic characterizations. ${ }^{17}$

In addition to regarding Shakespeare's characterizations in Antony and Cleopatra with these distinctions in mind, I have also tried to be aware of other of Shakespeare's dominant artistic tendencies. It is no surprise to anyone that the playwright tends to favor the inclusiveness of a psychological understanding over the narrowness of a simple moral interpretation of 
characters and that in both his dramas and poetry he sets the self-created dichotomy between psychological and moral perspectives in opposition throughout the gamut of his career. ${ }^{18}$ We shall see that Shakespeare complicates this conflict in composing Antony and Cleopatra, not only for his audience, but for the characters; we are frequently asked to look at the characters with wonder or awe rather than to inhabit them by slipping into their shoes, and we quickly learn that ambivalence and ambiguity frequently make their motives and actions difficult or impossible to fathom. Shakespeare also has a strong aesthetic interest in the diversity and changeability of conflicting public and private perspectives and an authorial curiosity in how we perceive that engrosses him as much as his attraction to what we perceive. As we shall see, his attention to these subjects holds an importance that strongly affects how he limns the characters and situations of Antony and Cleopatra and, therefore, how we respond to the characters' behavior; more particularly, these focal perspectives help to account for the unpredictability of Cleopatra's reactions and the discontinuities in Antony's.

Throughout this study, I have sought to remain mindful that Shakespeare was a fully engaged man of the theater, a context that does not allow us to concentrate disproportionately on thematic or ideological content but that necessitates a serious focus on practical considerations embedded in the theater culture of Shakespeare's day ${ }^{19}$ and on the linguistic and structural artistry of the play that he intended his audiences to notice. In effect, through the means of a powerful inventiveness in both language and genre, he teases us into thinking-perhaps even profoundly-about the differences between the artistic construct that the play is and the unstructured reality we experience daily, including our awareness of ourselves psychologically as theatergoers watching a performance of Antony and Cleopatra. In impressing upon us an understanding of the play as an innovative artistic achievement, Shakespeare inescapably becomes self-congratulatory. Because Antony and Cleopatra sustains such a pervasive emphasis on measuring up, it also may call upon us to compare the similarities and differences between our standards of measure and those of Antony, Cleopatra, and Octavius, historical icons intent on managing their images during their lives and for posterity. Comparisons of standards can only heighten our engagement with the play and our appreciation of it, as Shakespeare, on some level, may well have intended.

Anyone writing a monograph that focuses in detail on Shakespeare's Antony and Cleopatra may well have to begin the research component by 
overcoming a sense of intimidation at the overwhelming profusion of essays and books written about the play, many of them excellent. I cannot hope to have covered every article, book chapter, or book by scholars and critics that might bear on the present study, although I have certainly tried to read extensively and make use of those items that I know are regarded as seminal, especially those writings that have proved influential in providing incentives for later, significant developments in the history of the criticism on the play. Nor can I guarantee that I will not walk where others have already left strong footprints. But I have attempted to avoid some of the snares that critics have slipped into-in particular, the pitfall of those writers who have pressed too firmly an interpretive stance that is exclusive and reductive rather than inclusive and enlarging. This precaution explains why I have made an effort to examine some of the same textual evidence from more than one perspective.

In the six chapters that follow, I have endeavored to show how a consideration of measuring up and its connection with the enduring fame of the protagonists of the play can lead into a discussion of the mechanics of the formation of Shakespeare and his audiences' shared perspectives, beginning with the acknowledgment that they each have preconceptions about the main characters. Inevitably, the complex of issues raised in the play and the sophisticated artistic strategies employed throughout require close analyses of Act 1, a good bit of Act 4, and Act 5, with less extensive analyses of the personal, military, and political events of Acts 2-4. Inevitably, the differences in focus from chapter to chapter, as well as in some cases within chapters, indicate that my overall intention-to view the play from more than a single suggestive perspective while being moored to the permeating notion of measuring up to the standards that fame requires-bespeaks a willingness to entertain diversity. I like to imagine that such an attempt at multiplicity would have well pleased the Shakespeare of Antony and Cleopatra.

\section{NOTES}

${ }^{1}$ Marvin Rosenberg, ed. and completed by Mary Rosenberg, The Masks of Anthony and Cleopatra (Newark: University of Delaware Press, 2006).

2 Sara Munson Deats, "Antony and Cleopatra": New Critical Essays (New York: Routledge, 2005).

${ }^{3}$ The PMLA issue contains an article entitled "Celebrity Shylock" by Emily Hodgson Anderson (pp. 935-49), but it is historical in focus, discussing how 
Shylock, a fictional character, first acquired a celebrity status in the eighteenth century.

${ }^{4}$ Titus Andronicus, The Rape of Lucrece, Julius Caesar, Timon of Athens, Coriolanus, and Cymbeline.

${ }^{5}$ Listed throughout the book, but citing ambiguities has become a critical commonplace.

${ }^{6}$ Deats, New Critical Essays, pp. 1-93. See also Northrop Frye in Northrop Frye on Shakespeare, ed. Robert Sandler (Markham, ON: Fitzhenry \& Whiteside, 1986) who says, "The most elementary way of misreading this play is to turn it into either a moral or a romantic melodrama, against or for Cleopatra” (p. 124).

${ }^{7}$ L. T. Fitz, in her article "Egyptian Queens and Male Reviewers: Sexist Attitudes in Antony and Cleopatra Criticism," Shakespeare Quarterly 28 (1977): 297-316, asserts that "It is difficult to think of another Shakespearean play which has divided critics into such furiously warring camps" (p. 297). Although written some fifty years ago, most would agree that this situation still prevails.

${ }^{8}$ Janet Adelman in The Common Liar: An Essay on "Antony and Cleopatra" (New Haven, CT: Yale University Press, 1973) exemplifies the obfuscating uncertainties of the play (pp. 14-24) and the difficulties of coming to a judgment about characters and events (pp. 24-40): "The uncertainty of judgment characteristic of Antony and Cleopatra depends on our ignorance of the inner states of the characters and on their own insistent questioning; but it is also built into the dramatic structure of the play” (p. 30). In his book Shakespearean Tragedy: Genre, Tradition, and Change in "Antony and Cleopatra" (Cranbury, NJ: Associated University Presses, 1984), J. Leeds Barroll offers some important ideas about the variety of ways in which characters can be understood in Shakespeare's dramasin particular, in his second chapter entitled "The Human Figure on the Stage" (pp. 57-79). Although his focus differs from mine, it in no way contradicts it; moreover, we are both strongly in agreement that Shakespeare's characters should always be regarded as artistic constructs. Another book that treats the subject of characterization is Katharine Eisaman Maus' Inwardness and Theater in the English Renaissance (Chicago: University of Chicago Press, 1995). Maus sets out to "explore the afflictions and satisfactions that attend upon the difference between an unexpressed interior and a theatricalized exterior: the epistemological anxieties that gap generates, the social practices that are devised to manage it, and the sociopolitical purposes it serves" (p. 2).

${ }^{9}$ In a context very different from mine, Catherine Belsey, in her book The Subject of Tragedy (London; New York: Methuen, 1985), pp. 13-26, considers the distinction between what she calls "illusionism" and an "emblematic mode," which bear ties with my terms "realistic" and "representational." In discussing the two notions as they apply to spectators in a theater, she comments, "While emblematic staging displays the signified, makes meaning visible, illusionism reproduces the referent, replicates what is already visible, already known" (p. 24). Speaking from an historical perspective, she tells us that 
in the period between the precarious unity offered by the moralities and the stable, transcendent unity of the Restoration stage, from 1576 when Burbage built the Theatre to 1642 when the playhouses were closed, the stage brought into conjunction and indeed in collision the emblematic mode and an emergent illusionism. The effect was a form of drama capable at any moment of disrupting the unity of the spectator. (p. 26)

I arrived at my scheme through an examination of a viewer's or reader's common sense psychology, as Shakespeare might have understood it, and, as my discussion demonstrates, with a breakdown of types more extensive than Belsey's and predicated upon Shakespeare's recognition of the difference between "apprehension" and "comprehension."

${ }^{10}$ Except for references to Antony and Cleopatra, all references to Shakespeare's plays and poetry are from Stephen Orgel and A. R. Braunmuller, gen. ed. William Shakespeare: The Complete Works (New York: Penguin Putnam, 2002). All references to Antony and Cleopatra are from David Bevington, ed., Antony and Cleopatra (Cambridge: Cambridge University Press, 2005).

${ }^{11}$ Although commonly used in this sense, "identify" is unsatisfactorily vague. We may well identify a familiar psychological frame of mind of a character in a given situation, thereby deepening our emotional involvement with the character, including viewing the world of the play from the character's perspective. The degree of empathy we feel is not necessarily contingent upon the character's age, gender, profession, or social status but on his or her mental state and our sense, especially our felt sense, of kinship with it. Understandably, in watching a character on the stage or screen, our reactions are conditioned also by the individualized physical and behavioral characteristics of the person playing the role.

${ }^{12}$ See Bevington, Antony and Cleopatra, 1.2.108 note for an explanation of the confusion surrounding the number of messengers that appear in this scene.

${ }^{13}$ John F. Danby, "The Shakespearean Dialectic: An Aspect of Antony and Cleopatra," Scrutiny 16, no. 3 (1949): 196-213 at 206.

${ }^{14}$ I never may believe

These antique fables nor these fairy toys.

Lovers and madmen have such seething brains,

Such shaping fantasies, that apprehend

More than cool reason ever comprehends.

The lunatic, the lover, and the poet

Are of imagination all compact.

One sees more devils than vast hell can hold:

That is the madman. The lover, all as frantic,

Sees Helen's beauty in a brow of Egypt.

The poet's eye, in a fine frenzy rolling,

Doth glance from heaven to earth, from earth to heaven ...

(A Midsummer Night's Dream 5.1.2-13) 
${ }^{15}$ Because the plot is concluded by the end of Act 4, the speech also acts as a linchpin to connect us to Act 5.

${ }^{16}$ Vernon's ecstatic descriptions of Hal in 1 Henry $I V$ (4.1.97-110 and 5.2.51-68), although appropriately startling from a character from the enemy camp, are less an example of Shakespeare's unrestrained playfulness than an artistic need to elevate the Prince as we move toward the climax of the drama.

${ }^{17}$ Janet Adelman, The Common Liar, pp. 1-7, makes a worthwhile distinction between those plays of Shakespeare, primarily the comedies but also the histories, where the meaning of the play emanates from the design of the genre and those plays in which it emanates from the character of the protagonist, as the tragedies exemplify. Occasionally, the portrayal of characters in the comedies and histories impedes the design by asking to be responded to with psychic depth; Malvolio, Shylock, Falstaff, and Hal are her examples. She goes on to distinguish between our perceptual experiences, whether as theatergoers or readers (pp. 7-11), asserting that "The relationship of character to symbolic design shifts continually; the interplay may determine the meaning at any given moment" (p. 7). It is this point that gives additional support to the notion of kinetic characterizations and to the difficulties of response they present. In discussing Antony and Cleopatra, she declares, "both the presentation of character and the dramatic structure work to frustrate our reasonable desire for certainty. ... Although the play continually raises questions about motives, it simply does not give any clear answers to them" (p. 15).

${ }^{18}$ See Chapter 5 where this subject is treated more fully.

${ }^{19}$ To give an example: there is a difference in the degree of audience-actor intimacy between a late sixteenth-, early seventeenth-century theater and ours. Members of a Renaissance audience either stood or sat on three sides of a long rectangular stage that extended into a yard or pit during daylight hours; wealthy nobles could purchase seats on the stage itself. We are likely to sit in a darkened auditorium watching the action in front of us on a proscenium arch stage lighted and framed. Clearly, the Renaissance audience had a more active and closer rapport with the actors than we do. Such a rapport likely influenced the acting styles of the cast members. 


\section{Antony and Cleopatra in Seventeenth-Century Contexts}

$\mathrm{O}^{\mathrm{N}}$ N 20 MAY, 1608, "A booke Called Anthony. and Cleopatra" was entered in the Stationers' Register, but assuming, as scholarly consensus does, that this entry is also that of the 1623 Folio, the only authoritative text we have, the play seems not to have actually been published until 1623. If Samuel Daniel's 1607 second revision of his 1594 play Cleopatra was influenced by Shakespeare's play, then it means that Daniel must have seen Shakespeare's drama staged before the end of 1607 . By the same token, if Barnabe Barnes's The Devil's Charter, produced at court on 2 February, 1607, bears the influence of Shakespeare's play, then a probable date of composition of Antony and Cleopatra may have been $1606 .{ }^{1}$ These bits of information about the Stationers' Register and the suppositions that the plays of Daniel and Barnes reveal the influence of Antony and Cleopatra have led scholars, without any claims of certainty, to date the writing and first staging of Antony and Cleopatra between 1606-8.

The 1608 entry in the Stationers' Register may suggest that the play was well enough known to have had a commercially viable readership by that year. The entry may also suggest that it enjoyed such popularity on the stage that it made Edward Blount eager to publish the text. The "booke" was entered, along with Pericles, Prince of Tyre, but apparently unlike Antony and Cleopatra, Pericles was printed by another publisher in quarto form in 1609. Interestingly, Blount is the same man (along with Isaak Jaggard) to whom the play was licensed in 1623; but this time, he actually published it.

The first performances of the play are difficult to ascertain. ${ }^{2}$ One assumes from the 1608 entry in the Stationer's Register that the play was initially performed in 1606-7. The next suggestion of any performance of the play occurs in 1669 when Thomas Killigrew's company, the King's Men, were given performance rights to the play; but there is no indication of how the company may have staged the play or whether it did so. In that same year, the Lord Chamberlain's records tell us that the play was 
"formerly acted at the Blackfriars" but they do not indicate when or how many times. Without direct evidence, we can therefore only speculate about the initial and continuing popularity of the play.

Placing Antony and Cleopatra within the first eight years of the seventeenth century, in so far as we are able to, requires an understanding of at least three interwoven groupings of circumstances or contexts:

1. the sources of and influences on the play, including the dramas of Shakespeare's contemporary dramatists and the popular interest in historical Roman subjects;

2. the commercial, pragmatic, aesthetic, and moral demands of the theatre culture of the day;

3. the sociopolitical and religious climate of the day.

Of these three contexts, the content of Shakespeare's dramas seems least affected by the third. ${ }^{3}$ That is not to say that the dramatizations of power, powerlessness, and their consequences are not grounded in Shakespeare's understanding of past events and present happenings in his own milieu. But he so universalizes his understanding that actual, topical happenings are not easy to detect. If we look at Shakespeare's Roman writings-Titus Andronicus, The Rape of Lucrece, Julius Caesar, Antony and Cleopatra, Coriolanus, and Cymbeline - we find that his interest in characterization and the vagaries of human behavior takes precedence over such sociopolitical concerns as whether a republic is a healthier form of government than a monarchical dictatorship. Even though Antony and Cleopatra centers on that moment in history when Rome was transitioning from the end of a republican era to the beginning of an imperial one, Shakespeare, following Plutarch's and his own chief interest, cultivates his fondness for concentrating on the personal behaviors of his characters, thereby playing down the many complex political and military issues that actually enveloped them. For the playwright, history has to do primarily with figures in striking, particularized situations, not historical events or issues, even if they are implicated. To be sure, portraying the universalized conflicts and tensions between two differing political systems makes for good theatre, as Julius Caesar, Antony and Cleopatra, and Coriolanus all demonstrate. But Shakespeare seems little concerned that these plays assume a political stance. If he were, then one could infer from his position what he thought about Queen Elizabeth's reign or that of King James and the early seventeenth-century sociopolitical upheavals. 
The same lack of interest in assuming a sociopolitical ethical position or in proselytizing is evident in his attitude toward the religious turmoil of the early seventeenth century. He makes use of biblical allusions and metaphors anachronistically in Antony and Cleopatra without ever shaping them into a recognizable religious belief, let alone that of a specific denomination. But of course the pre-Christian setting makes neutrality an easy perspective to adopt. As they are dying, both Antony and Cleopatra fantasize about an afterlife of sorts:

Antony: I will o'ertake thee, Cleopatra, and Weep for my pardon....

$(4.14 .43-44)$

Eros!-I come, my queen.-Eros!-Stay for me.

Where souls do couch on flowers, we'll hand in hand,

And with our sprightly port make the ghosts gaze.

Dido and her Aeneas shall want troops,

And all the haunt be ours.

$(4.15 .50-54)$

Cleopatra:

Methinks I hear

Antony call. I see him rouse himself

To praise my noble act. I hear him mock

The luck of Caesar, which the gods give men

To excuse their after wrath. Husband I come!

Now to that name my courage prove my title!

(5.2.277-82)

If she [Iras] first meet the curlèd Antony,

He'll make demand of her, and spend that kiss

Which is my heaven to have.

(5.2.295-97)

Antony imagines himself and Cleopatra in a Virgilian Elysium, and Cleopatra envisions a post-death interaction with Antony in an undesignated locale. But these fantasies hardly constitute a religious belief. They seem, rather, to be the protagonists' spontaneous emotional attempts to help motivate themselves, thereby putting as positive a face on their suicides as possible.

Can we therefore conclude that by the time Shakespeare writes Antony and Cleopatra, his implicit, self-appointed rule of thumb appears to be a firm conviction that poetry and drama are to entertain without 
making or even wanting to make a distinct, moral imprint on audiences in the form of either a sociopolitical stance or a religious belief? Are there simply no such didactic arrows in his quiver? We can infer from the plays and the Sonnets that bonding, although always subject to the vicissitudes of fortune and flux, provides the basis for the apotheosis of human happiness in what might be designated as ultimate mortal reality. But Shakespeare affirms this commonplace position without slipping into a proselytizing mode. At a time when moralizing was so strong a prevailing fashion, Shakespeare's resistance to it, amounting to a stand against it, is truly remarkable. As we shall see, Antony and Cleopatra shows itself well aware of the personal and political defects attendant upon moralizing even as it makes aesthetic use of the moralistic mode for dramatic purposes. ${ }^{4}$

This argument is not meant to suggest that, apart from his engagement in the literary and theater cultures of his day, Shakespeare was oblivious to current events. But his plays seldom reveal that these events influenced him in a way that enables us to detect topical happenings or biases emerging from them. The limitations imposed by censorship restrictions apart, ${ }^{5}$ Shakespeare stands out among his contemporary fellow dramatists in his avoidance of dramatizations of social, political, and military upheavals that might reflect local occurrences and thus shift the main focus from people to issues - that is, from concrete sensory and emotional reactions to reasoned, theoretical ones. A clear example of this is the playwright's lack of interest in Cleopatra as a powerful political force in her own right, clearly the phenomenon that secured her entrance into the annals of history well before she encountered Antony. In the course of the play, we primarily find her in situations that reveal aspects of her private rather than her professional life as a ruling monarch. Although we see that she has a strong sense of what it means to appear regal, we are led to understand some of her force as a political figure by implication only. We never are privy to how she conducts business as the ruler of Egypt. Nor do we ever have many details about Antony's actions as a triumvir. In Shakespeare's plays as a whole, actions involving assertions of social, political, or military power are sketchily handled, generalized and universalized, or given enough of a human context so that we do not become embroiled in issues that would relate to the playwright's real-life context. ${ }^{6}$ The brief appearance of Glendower in 1 Henry IV 3.1 is a case in point. Although seriously involved in the rebellion against the King, we remember the Welshman more for his idiosyncratic personal characteristics, including his magical 
powers in calling musicians from afar to accompany his daughter's vocalizing, than for his significance as a political or military figure. John Keats famously described the psychology of Shakespeare's involvement with his characters when he discussed the playwright's "Negative Capability" and asserted, using Shakespeare's ability to create such opposites as Iago and Imogen, that the "Poet" has "no Identity." $\mathrm{He}$ indicates that Shakespeare is so thoroughly engaged when developing his characters' perspectives, that his imaginative projection is total. This tendency may suggest why Shakespeare is both unable and, ultimately, unwilling to place his focus elsewhere. His engagement with many of his characters is so complete that it occludes all but the perspectives of the characters within a particularized situation. ${ }^{9}$ Clearly, such concentration eliminates the possibility of incorporating reflections on issues. Moreover, his primary creative impulse is to think situationally, with concreteness, not abstractly. Therefore, for all we can discover from the plays, detached non-involvement and neutrality are his usual responses to topical sociopolitical issues. ${ }^{10}$

The sources and influences of Antony and Cleopatra have been extensively discussed, and there is little need to rehearse them here. ${ }^{11}$ They reveal a remarkable multiconsciousness in Shakespeare's powers of absorption. They also suggest that he was an avid reader. Not only has he been sensitive to a plenitude of poetic, dramatic, and historical accounts that we know about, but he was also probably aware of sources and influences of which we know almost nothing. An example of the latter is Fulke Greville's tragedy entitled Antony and Cleopatra, written in 1601, two years before the end of Queen Elizabeth's reign. Fearing that its focus on the demise of ambitious rulers might be taken as a reflection of the evils of the present monarch, Greville destroyed it by burning it. No evidence exists to ascertain whether Shakespeare knew of the play. Nevertheless, it stands as one more indication that the story of the famous couple was a widespread, popular commercial vehicle. As a subject of enduring interest, the dynamic of Love versus Duty was embedded in the culture; all versions of the story of Antony and Cleopatra take it into account. In 1965, Paul Jorgenson pointed out that, at the time that Shakespeare was writing Antony and Cleopatra, there was a strong tradition in both drama and poetry of the conflict between a soldier's duty and a distracting lover, and that, frequently, it was linked with the relationship between Mars and Venus. ${ }^{12}$ That Shakespeare was well acquainted with this tradition is no surprise. In Venus and Adonis, Venus brags at length that "he that overruled I overswayed" (1.109), proudly alluding to Mars as "my captive and 
my slave" (1. 101). ${ }^{13}$ Antony and Cleopatra makes reference to this tradition, beginning with the opening speech when Philo says of Antony,

Those his goodly eyes,

That o'er the files and musters of the war

Have glowed liked plated Mars, now bend, now turn

The office and devotion of their view

Upon a tawny front.

$(1.1 .2-6)$

Four scenes later, when the eunuch Mardian tells Cleopatra that he has "fierce affections, and think[s] / What Venus did with Mars" (1.5.1819), the Queen immediately thinks of her relationship with Antony. In Rome, Enobarbus, in a non-conciliatory mood, declares to Lepidus, "Let Antony look over Caesar's head / And speak as loud as Mars" (2.2.5-6). In a quite different frame of mind, Enobarbus tells Agrippa and Maecenas that Cleopatra "did lie / In her pavilion-cloth of gold, of tissue- / O'erpicturing that Venus where we see / The fancy outwork nature" (2.2.208-11). A final, and very significant instance is Cleopatra's estimate of Antony after she learns that he has married Octavia: "Though he be painted one way like a Gorgon, / The other way's a Mars” (2.5.118-19). What is noteworthy here is that in each of these examples, Shakespeare is using the analogy to elevate the protagonists, not to make a seriously critical, moral point that denigrates either one. In this way, he employs the moralizing tradition against itself.

George Peele's The Turkish Mahomet and Hiren the Fair Greek, a lost play referred to by Pistol in 2 Henry IV (2.4.167-68: "Have we not Hiren here?"), features the clash of desire and duty that we see in Antony and Cleopatra. The lost play Hester and Ahasuerus appears to contain the same Aeneas-like conundrum, Love versus Duty. ${ }^{14}$ These plays indicate that the basic conflict within Antony was not only tremendously popular as a source of entertainment but also, evidently, a guaranteed commercial success. Shakespeare's dramatization differs from other versions of the conflict, placing it in a psychological context to account for a character's behavior rather than presenting it as a moral issue adjudicated by a writer eager to assuage an audience through instruction. For Shakespeare, moral issues are primarily a dramaturgical means for providing non-didactic entertainment, thereby differing from the intent of other authors, past and present, whether dramatists, poets, or writers of prose. More often than not Shakespeare's psychological context makes 
clear why we cannot come to a judgment rather than establishing a causal relationship that explains why we can. Cleopatra's entertainment of Thidias (3.13) and Antony's abject humility before the servitors (4.2) are cases in point.

Much has been written about the popularity of Roman history and literature in the Renaissance and its influence on Shakespeare. The most recent study of the cultural presence of Rome in sixteenth-and seventeenth-century England, Warren Chernaik's The Myth of Rome in Shakespeare and His Contemporaries, emphasizes not only the widespread nature of the English interest but also underscores the diversity and ambivalence in the attitudes toward Rome. ${ }^{15}$ Chernaik tells us that "According to one recent list, forty-nine ... [plays with "Roman themes"] ... are extant, and the titles of forty-five additional 'Roman' plays survive" (p. 5). On the one hand, the personal and sociopolitical ideals of Roman conduct, almost exclusively applicable to the behavior of males, are exalted; but, on the other, the actual barbarism of Roman behavior is denigrated. Cleopatra herself is an active participant in both beliefs. She is wary of "a Roman thought" and all that it implies; she shrewdly sizes up Caesar for the ruthless politician he is, proudly traducing him during her suicide as an "ass / unpolicied" (5.2.301-2); and she roundly denounces the crudeness of the Roman populace and the lack of imagination in the Roman entertainers whom she senses are low-grade (5.2.206-20). But she also wants to commit suicide "after the high Roman fashion" (4.15.92), because it is "what's brave, what's noble" (4.15.91). Antony himself has been torn between an older order of idealized Roman values and the present emphasis on unfeeling opportunism and brutal ruthlessness, but in dying he opts for the former: "a Roman by a Roman / Valiantly vanquished” (4.15.59-60). Throughout this play (as well as in Shakespeare's other Roman works), Roman values are frequently scrutinized. Whereas Shakespeare portrays the success of the Romans, he is especially sensitive to the costs, whether they be the horrendous mutilations and murders in Titus Andronicus; the vile rape of Lucretia; the savagery of the mob murder of Cinna the poet and the proscription list drawn up ruthlessly by Antony, Lepidus, and Octavius in Julius Caesar; the consequences of Octavius's callousness-causing the deaths of most of the major historically significant figures in Antony and Cleopatra: Pompey, Lepidus, and the two protagonists; the fierce criticism of Roman values in Coriolanus; or the destructiveness of war in Cymbeline. Because the overall attitude toward Rome is ambivalent, even though it seems focused in Shakespeare's 
plays on the dark aspects, we find once again that the playwright's chief interest appears to be aesthetic. He seems more concerned with how he can make dramatic use of conflicting perspectives on Rome than with analytically exploring and ruminating on the complicated and often contradictory values associated with the empire or with coming to a judgment about what values he supports.

Theater historians have opened the door to an understanding of the commercial, pragmatic, aesthetic, and moral demands of the theater culture of the day. The problem is that whereas we are able to acknowledge unquestionably that the economics of the early modern theater are of prime consideration in our understanding of this context, we simply do not have the evidence necessary to flesh out our knowledge. S. P. Cerasano lists the difficulties theater historians have in researching early modern theater culture, but she also reminds us that "regardless of all the difficulties embedded in this research, and the very real limitations barring our access to historical data, attempting to understanding economic issues remains central to our discussion of theatrical culture." ${ }^{16}$ This statement brings to mind one of the favorite shibboleths of modern day economists, "No marts, no arts." Thus, no matter how much scholarship is directed toward playwrights and their plays, it is accurate to understand the prime importance of economics and to further understand that theater owners were almost exclusively concerned with profit, not aesthetics. Nor were they concerned with the celebrity status of playwrights or actors unless, by chance, it was a means of bringing more people into the theater.

A strong example of an informative essay that covers the period when Antony and Cleopatra seems to have been written and first performed is Tom Rutter's "Adult Playing Companies: 1603-1613." ${ }^{17}$ Rutter discusses the salutary changes in the patronage system during the reign of James I, the prosperous commercial fortunes of the theaters and actors in London during this period, "relationships between players and playhouse owners, plague, competition," 18 and the relative economic stability of the adult professional theater, especially those playing companies under royal patronage: the King's Men, the Queen's Men, Prince Henry's Men, and Lady Elizabeth's Men. The demand for new plays was escalating; as Rutter comments, "the success of all the adult companies depended on their being able to stage a large and evolving repertoire of plays which capitalized both on their own and on other companies' successes." ${ }^{19}$ From company to company and playhouse to playhouse, the repertories were both similar and yet also individualized and distinctive; moreover, presentations at 
court increased, and, as a result, masques became more popular. Theatrical presentations were fast becoming progressively innovative.

Antony and Cleopatra reflects Shakespeare's security as a playwright. He was attuned to what would make the play commercially successful, because he knew that his audiences were fond of historical subjects, Rome in particular, and that his protagonists were already famous. Moreover, he must have felt confident about such pragmatic matters as the availability of actors for the roles. The part written for the actor playing Cleopatra suggests that he had an exceptionally, even uniquely talented youth or possibly a somewhat older actor in mind to play the role. The role of the humorous Clown who brings Cleopatra the asps also could have been written with a specific actor in mind. In including him as a characterthe result of choice, not necessity-the playwright hearkens back to the kind of ignorant but well-intentioned unsophisticated, socially awkward figures in his early comedies-for example, Dogberry or Lancelot Gobbo's father. We do know that Will Kempe was an actor famous for clown parts in Shakespeare's plays and that Robert Armin succeeded him in 1599. Thus, it is possible that Shakespeare introduced the Clown in Antony and Cleopatra because he had a celebrated actor in mind to play the role, even if only briefly. Because he knew that audiences were accustomed to enjoying this type of role, it would make perfect sense to present a well-known actor in this cameo role at the climax of the play. Of course, he may not have used a celebrated actor for the part but simply had one of the actors already in the play double in the role. The appearance of the Clown may also reflect the entrepreneurial desire to cater to audiences that were socially diverse.

In general, the patronage system during the time of King James allowed for fewer restrictions on playhouses, theater owners, actors, and the plays than had been imposed under Elizabeth I and the London authorities. But, specifically with regard to Antony and Cleopatra, there is nothing in the play that would have required censoring. As Cerasano indicates, "two critical features differentiated it [the theater business] from other business settings: the lack of any professional regulation and a lack of any commercial protection." ${ }^{20}$ As a result theater owners endured risks, became resourceful, and focused single-mindedly on commercial concerns. As both a theater owner (investor) and a playwright, Shakespeare had a business acumen that to some extent guided him in the selection of subjects and characters for his plays. We can assume, therefore, that one strain of influence as he was writing Antony and Cleopatra was his sense of what would maximize the profit of performances of the play. 
His aesthetic sense was, of course, both inborn and learned-the latter, from the combination of schooling, reading on his own, his involvement in his own theater productions, and his knowledge of the productions of others. From our contemporary perspective, the aesthetic triumph of Antony and Cleopatra resides foremost in the language of the play. It stands out as unique in its imaginative freshness, range, variety, and metaphorical splendor. Apart from the heightened sensitivity of seventeenthcentury audiences to language usage, Shakespeare's linguistic inventiveness throughout the play probably was more enticing to the educated members of his audience than to the less schooled groundlings. Even so, the ubiquitous interest in the dramatized personal lives of two longstanding celebrities and the idealization of bonding and loyalty-portrayed, not only through the lives and deaths of Antony and Cleopatra and Pompey's devotion to his father, but also through the deaths of Enobarbus, Eros, Iris, and Charmian-very likely had widespread appeal.

In addition, the ways in which Antony, Cleopatra, Octavius, and Enobarbus cope with their awareness of their mortality-forging their current identities and lasting reputations, and the manner of the deaths of three of them-must have sparked interest in all audience members. Achieving immortality through the written word, a notion that Shakespeare dwells on in his Sonnets, takes the form of the historical record in the play and for the characters is the best defense against death that mortal beings can achieve. All four characters have a sense that they will be part of the historical record, a belief that enables them to defend themselves against what James Calderwood wittily terms the "biological embarrassment" ${ }^{21}$ of death-that is, Hamlet's solemn concern with transcending our "bestial oblivion" (4.4.40). Antony promotes the legend of his heroics during the course of the play but especially as he is dying:

\footnotetext{
The miserable change now at my end

Lament nor sorrow at, but please your thoughts

In feeding them with those my former fortunes, Wherein I lived the greatest prince o'th'world, The noblest; and do now not basely die, Not cowardly put off my helmet to My countryman-a Roman by a Roman Valiantly vanquished. Now my spirit is going; I can no more.
} $(4.15 .53-61)$ 
After Antony's demise, Cleopatra magniloquently carries forward and even strengthens the continuance of his glorified legendary heroics in speaking to Dolabella (5.2.75-99). In fact, her eulogy goes a long way toward permanently idealizing Antony's heroic image. In staging her own suicide, the Queen dies with regal splendor, adopting the myth of "the high Roman fashion" (4.15.92), while, at the same time, rejecting the impoverished aesthetics of the "saucy lictors," "scald rhymers, and "quick comedians" of Rome (5.2.213-15). She is especially pleased to exert creative control over her death and to exult in casting "great Caesar" as an "ass unpolicied" (5.2.301-2). Caesar is conscious of his enduring fame throughout the play, especially with regard to his power over his political foes and over Antony and Cleopatra in particular. Enobarbus, stricken with guilt at his betrayal of loyalty to Antony, asserts as he dies: "let the world rank me in register / A master-leaver and a fugitive" (4.9.21-22). In spite of his misery and ignominious death from a broken heart, he believes in "the living record of your memory" (Sonnet 55, 1.8), the myth of immortality that the historical record will provide. Thus, all four figures share in the denial of death by configuring their place in history and, all but Enobarbus, with varying degrees of creative energy and solace.

If Shakespeare's characters feel the need to overcome the awareness of death throughout their lives by subscribing to the notion of identifying and even shaping their place in recorded history-a form of measuring up to self-created and sociopolitical standards, then it is not surprising to find a parallel in the dramatist himself. In composing dramas, assisting in producing his plays, taking on the role of a player, and participating in the business of the theater as an investor, Shakespeare found creative endeavors that absorbed him on a daily basis, helping him avoid whatever emotional and intellectual struggles he may have had with the degenerative effects of passing time and the inevitability of death. Although he most probably had no idea that his plays would bring him eternal fame, if his Sonnets, Venus and Adonis, and The Rape of Lucrece are an accurate indication, he may well have had hopes that his poetry would place him in the ranks of the known writers of his day. Like Antony and Cleopatra, he undoubtedly understood the value of creative energy and involvement in constant activities in the denial of death, as well as the irony that the fire of one's creative energy would ultimately be "Consumed with that which it was nourished by" (Sonnet 73, 1. 12). Both in understanding intuitively the psychology of diurnal living with the consciousness of "sad mortality" (Sonnet 65, 1.2) and in the contemplation of achieving lasting fame, 
Shakespeare knew, as the four chief figures of Antony and Cleopatra knew, that the ultimate, most secure, symbolic defense against death lay in the written word, accompanied by whatever additional myth making oral tradition might provide. Since death is the annihilator of all differences, the written word best counters such leveling, for in individualizing through extraordinary particulars, it can record the deeds (good or bad) of all memorable persons, establishing and sustaining their fame, notorious or not. With incomparable talent, Shakespeare invests fully in this linguistic aesthetic not only to memorialize the young man of the Sonnets and the noteworthy characters of his plays but also, with perhaps considerably less self-consciousness and attention to self-promotion, to offset the leveling necessitated by his own death.

\section{NOTES}

${ }^{1}$ For a more detailed description of the supposed date of composition and two entries in the Stationers' Register, the second leading to the Folio text we have, see J. Leeds Barroll, “The Chronology of Shakespeare's Jacobean Plays and the Dating of Antony and Cleopatra," in Essays on Shakespeare, ed. Gordon Ross Smith (University Park: Pennsylvania State University Press, 1965), and Bevington, Antony and Cleopatra, pp. 1-2.

${ }^{2}$ See Martin Spevack, A New Variorum Edition of Shakespeare: "Antony and Cleopatra" (New York: Modern Language Association of America, 1990), pp. 758-60 for a discussion of the "first attempts" at performances.

${ }^{3}$ In Playing Companies and Commerce in Shakespeare's Time (Cambridge: Cambridge University Press, 2001), Roslyn L. Knutson treats the impact of Shakespeare's political environment on commercial strategies in the production of early modern plays, showing "that commerce among the playing companies was built on patterns of fraternity, the roots of which were feudal hierarchies such as kinship, service, and the guild. ... By a combination of sanctions and limitations, various political powers-e.g., lords, Privy Council, aldermen, lord mayor, Bishop of London-defined a space wherein the companies could do as they pleased commercially" (p. 10). See, in particular, her second chapter, "Players and company commerce," pp. 21-47. From such a historical, pragmatic perspective, one can assume that the contemporary political/religious environment must have engaged Shakespeare on a daily basis and perhaps may give us one reason why, as an escape, he eagerly fastened onto Roman subjects. Generally speaking, his real-life milieu does not allow us to detect specific political/religious effects on the content of the plays with certainty. In his book, The Year of Lear: Shakespeare in 1606 (New York: Simon \& Schuster, 2016), James Shapiro has a lengthy chapter on Antony and Cleopatra (pp. 224-47), but unlike his discussion of King 
Lear, the discussion of the Roman play does not make connections with the 1606 milieu. The obvious reason is that there is no evidence to make such connections apart from a Jacobean painting, a portrait seemingly of Lady Anne Clifford, that “portrays Cleopatra’s final, fatal act with great sympathy" (p. 245).

${ }^{4}$ There are abundant instances throughout Shakespeare's plays where moralizing is shown to have absolutely no effect. In Richard II, for example John of Gaunt's moralizing to his son and to Richard cause Bolingbroke to respond with skepticism and Richard with anger. Examples are equally prevalent in later plays. In the opening scene of King Lear, for instance, Kent's words of advice only enrage the king. In Antony and Cleopatra, Charmian's moralizing evokes Cleopatra's strong response: “Thou teachest like a fool" (1.3.10), and Lepidus's attempt to enlist Enobarbus in keeping Antony calm only meets with defiance (2.2.1-14). Moreover, Antony turns a deaf ear to those who advise that he fight by land, not by sea (3.7). See also some further discussion of this topic in Chapter 5.

${ }^{5}$ By the Master of the Revels. But as Andrew Gurr points out in The Shakespearean Stage: 1574-1642, 4th ed. (Cambridge: Cambridge University Press, 2009), “The examples of satire that drew the censor's attention are only the peaks of a mountain of contemporary allusions" (p. 33). Thus, one could not say that, in general, censorship was rigorously applied.

${ }^{6}$ The only example of this tendency in Antony and Cleopatra is the Queen's well known words to Iras, "I shall see / Some squeaking Cleopatra boy my greatness / I'th'posture of a whore" (5.2.218-20). These words evoke the immediate theatrical conditions of the audience sitting in the playhouse but nothing involving celebrated current events.

${ }^{7}$ John Keats: Selected Poems and Letters, ed. Douglas Bush (Boston: Riverside Press, 1959), p. 261. The phrase "Negative Capability" is used by Keats in a letter to George and Thomas Keats, dated December 1817 (pp. 260-61), in which he speaks about Shakespeare.

${ }^{8}$ John Keats: Selected Poems and Letters, p. 279. Keats said the "Poet" has "no Identity" and spoke about "poetical Character" (p. 279) in a letter to Richard Woodhouse, dated October 27, 1818.

${ }^{9}$ As Keats says, in defining it, "Negative Capability" is the quality that forms "a Man of Achievement especially in Literature \& which Shakespeare posessed $[$ sic $]$ so enormously"; it occurs when said "man is capable of being in uncertainties, Mysteries, doubts, without any irritable reaching after fact \& reason” (John Keats: Selected Poems and Letters, p. 261).

${ }^{10}$ The one clear exception to this generalization, as Hamlet 2.2 and 3.2 make clear, is the references to happenings in the theater culture of the day and to dramaturgical aesthetics. Scholars have attempted to draw parallels between events of various plays and current situations, but they tend to be largely speculative. In Timon of Athens, for example, the dramatization of reckless spending and poor money management has been linked to the spending habits of aristocrats in the early seventeenth century and to James I himself. 
${ }^{11}$ For the most comprehensive summary, see Spevack, $A$ New Variorum, pp. 384-611. My participation in the discussion appears in "Violence, Terrorism, and War in Marlowe's Tamburlaine Plays," in War and Words: Horrors and Hallelujahs, ed. Sara Munson Deats, Lagretta Tallent Lenker, and Merry G. Perry (Lanham, MD: Rowman and Littlefield, 2004), pp. 65-81; “'High Events as These': Sources, Influences and the Artistry of Antony and Cleopatra", in Deats, New Critical Essays, pp. 153-74; and Ch. 7: "Making the Haunt His: Dido, Queen of Carthage as a Precursor to Antony and Cleopatra," Shakespeare's Marlowe: The Influence of Christopher Marlowe on Shakespeare's Artistry (Aldershot: Ashgate, 2007), pp. 169-95.

${ }^{12}$ Paul Jorgenson, "Antony and the Protesting Soldiers: A Renaissance Tradition for the Structure of Antony and Cleopatra," in Essays on Shakespeare, ed. Gordon Ross Smith (University Park: Pennsylvania State University Press, 1965).

${ }^{13}$ The passage in Venus and Adonis is from lines 97-112.

${ }^{14}$ See the Lost Plays Database, http://www.lostplays.org/index.php.

${ }^{15}$ Warren Chernaik, The Myth of Rome in Shakespeare and His Contemporaries (Cambridge: Cambridge University Press, 2011). Roslyn L. Knutson, in her book The Repertory of Shakespeare's Company, 1594-1613 (Fayetteville: University of Arkansas Press, 1991) discusses reasons for the commercial success of the Elizabethan repertory system and notes that "Shakespeare supplied the kinds of plays that audiences liked, with stories that they liked, in dramatic formulas that they liked" (p. 168). "After his first few years with the company, Shakespeare continued to choose historical matter that appealed to playgoers. Julius Caesar, Antony and Cleopatra, Coriolanus, and Timon of Athens benefit from the popularity of Roman history plays generally, as reflected in such offerings in the repertory of the Admiral's men as the two-part Caesar and Pompey (1594-95), the Tragedy of Phocas (1595-96), and Jugurtha (1599-1600)" (p. 169).

${ }^{16}$ S. P. Cerasano, "Theater Entrepreneurs and Theatrical Economics" in The Oxford Handbook of Early Modern Theatre, ed. Richard Dutton (Oxford: Oxford University Press, 2009), p. 381.

${ }^{17}$ The essay is Chapter 4 of The Oxford Handbook of Early Modern Theatre, ed. Richard Dutton (Oxford: Oxford University Press, 2009), pp. 72-87.

${ }^{18}$ Rutter, "Adult Playing Companies," p. 87.

${ }^{19}$ Rutter, "Adult Playing Companies," p. 82.

${ }^{20}$ Cerasano, “Theater Entrepreneurs," p. 386.

${ }^{21}$ James Calderwood, Shakespeare and the Denial of Death (Boston: University of Massachusetts Press, 1987), p. 6. 
Chapter 3

\section{“Immortal Longings": Shakespeare's Perspective On Fame}

The purest treasure mortal times afford Is spotless reputation. That away

Men are but gilded loam or painted clay.

Richard II 1.1.177-79

Before Shakespeare composed his biographical dramatization of the last ten years of Antony and Cleopatra's lives, the story of the lovers had evolved into a well-established cultural fabrication, stimulating the imaginations of admirers and detractors alike for over sixteen centuries. At the time the dramatist created his version (ca. 1604-6), a moralistic denunciatory perspective toward the pair clearly predominated. ${ }^{1}$ As Shakespeare's play attests, negatively categorizing the behavior of Antony and Cleopatra had not resulted, as in many cases such categorizing can, in writing off and forgetting the persons who have been judged and labeled. The list of classical, medieval, and Renaissance authors whose depictions preceded Shakespeare's play bears ample testimony to the continuing widespread popularity, as well as the variety, of the fictionalized accounts of "such a mutual pair / And such a twain" (Anthony and Cleopatra 1.1.39-40). ${ }^{2}$

In deciding to follow Titus Andronicus and Julius Caesar with another Roman play about the personal and professional lives of famous political and military leaders and their conquests, Shakespeare knew that he could count on substantial public interest in the historical figures that make up the dramatis personae of Antony and Cleopatra. ${ }^{3}$ Neither Shakespeare nor his audience would have expected that the story could be told without portraying some additional degree of illusion; detailed biographical and historical accuracy were not the objectives. In addition, the playwright naturally assumed that he could rely on an audience's insatiable appetite for stories. Like Sir Philip Sidney, Shakespeare well understood 
the psychological power of a story or tale. In "An Apology For Poetry," while extolling the superior virtues of the "poet," Sidney declares, "with a tale forsooth he cometh unto you, with a tale which holdeth children from play, and old men from the chimney corner." ${ }^{\text {"T }}$ Thus, the playwright must have sensed that this universal psychological penchant, especially in an eager theater audience, would only be intensified if the figures being dramatized were known to be famous.

Joseph Roach points out that "celebrities succeed by the unresolved copresence of mutually exclusive attributes - strength and vulnerability, innocence and experience, singularity and typicality among them." Although this statement sometimes is and sometimes is not also true of figures of fame, his description of the "beguiling of charismatic attraction" ${ }^{6}$ helps to account for Shakespeare's sense of what makes Antony and Cleopatra compelling as dramatic figures. Moreover, the artistic device of dramatizing inconsistencies in the behavior of the famed couple gives audiences a seemingly realistic sense of intimacy with them.

Given Shakespeare's joint creative and entrepreneurial interests as a fully-involved man of the theater, it is likely that, in choosing to compose a drama about the renowned lovers, he was motivated by a complex combination of external circumstances and personal impulses: the public's and his own abiding interest in familiar historical persons, both English and Roman; his audience's and his own aesthetic fascination with high-profile Romans whose private and public value systems were considered potentially paradigmatic; a well-conditioned commercial desire to invest his imaginative powers in theatrical subjects that would yield a good profit; the availability of celebrated or potentially celebrated actors for the roles; the dramatic possibilities offered by his continuing fascination with different cognitive modes and varied perspectives in human behavior; and a heightened dramaturgical interest in what for him was, increasingly, an inevitable conflict between personal desires and sociopolitical demands.

Moreover, Shakespeare's absorption in Antony and Cleopatra's enduring fame quite likely bore ties with his lifelong interest in writing about various pragmatic and psychological means for overcoming the ravages of time. ${ }^{7}$ This concern motivated him to speak about two courses of action that could be adopted to extend a person's existence, one of which he considered crucial in establishing and sustaining someone's fame after death. As we learned in the previous chapter, the Sonnets tell us that Shakespeare considered poetry or, more generally, the written word to be the chief practical means of assuring permanence: "Not marble, nor 
the gilded monuments / Of Princes, shall outlive this powerful rhyme" (Sonnet 55, 11. 1-2). He understood that written accounts, whether in the early modern inclusive sense of "poetry" or some recorded form of history, could ensure the permanence of famed persons. The record of writings on Antony and Cleopatra before and after Shakespeare readily verifies the written word as humankind's most potent resource for guaranteeing imperishable fame. Intentionally or unintentionally, written works can also be responsible for assisting in immortalizing their authors. Furthermore, we know from the fact that Shakespeare's own lineage died out that immortalizing the subject through writings was a more secure means than the other chief practical means focused on in the Sonnets, extending one's existence and outstanding characteristics (ideally) through procreation.

Whether Shakespeare considered theatrical representations a form of permanence is unclear, especially since he did not see his plays through the press. One would gather that he did not. Psychologically speaking, however, he well understood that people are able to "drown consideration" (4.2.46), to block out temporarily their awareness and fears of advancing time, through actions that engage them fully. Applying this same principle to Shakespeare the writer, we can speculate that the act of composing, especially when riveting, was also an effective personal means of eluding the impression of mutability's destructiveness, whether felt or perceived. For all writers of fiction and to some degree for writers of nonfiction, there must be a sense of godlike empowerment since they are not only able to control the configurations of the characters, their actions, and the milieux of their worlds, including arrangements of the interconnections of all three, but also the pace at which time passes and events occur. In Antony and Cleopatra, the two lovers express their awareness of the debilitating physical and psychological effects of the passage of time, Antony more often than Cleopatra. ${ }^{8}$ To fend off the unhappiness that such thoughts bring, both protagonists involve themselves in activities and actions that fully absorb them-whether love, pleasure, politics, or combat. Their wholehearted exertion of creative energy temporarily shields them from their consciousness of mutability and, at the same time, enables participation in incidents that redound to their enduring fame. Even when Antony and Cleopatra are not measuring the effect of their activities and actions on their current reputation or enduring fame, their behavior perpetuates their legendary status; ${ }^{9}$ the audience views them with curiosity and engagement simply because they are known as famed historical persons and new details about their private lives are being suggested. Whether the 
details are true or fictional does not seem to matter to those eager to hear more about famous figures.

In Antony and Cleopatra, the appearance of transcending time is portrayed as the ingredient most essential for achieving fame. Both lovers are lauded with an apotheosis of praise for their apparent triumphs over mutability, usually the result of demonstrating a godlike skill in which they appear to make time stand still and show themselves (at least momentarily) unaffected by the slings and arrows of outrageous fortune and change: Enobarbus calls Cleopatra a woman of "infinite variety" (2.2.246) whom "age cannot wither," "nor custom stale" (2.2.245), and Cleopatra addresses Antony as "infinite virtue" (4.8.17) for his heroics in battle. ${ }^{10}$ Paralleled by the word "infinite," these two tributes exalt the remarkable ability of the pair to transcend the laws of nature and time quite instinctively through their actions. No other play by Shakespeare displays such a strong preoccupation with the sources of permanence in relation to lasting fame. But, then, none of the other plays portraying prominent historical figures contains a conflict of private and public interests that, because of a central focus on irrepressible love, has such widespread appeal. To be sure, as the playwright undoubtedly knew, this appeal had been securely linked to the familiar dichotomy between love and duty, which was at least as old as The Aeneid and, apparently, a perennial favorite among storytellers and historians in Shakespeare's day. ${ }^{11}$

From the perspective of Antony, the process of sustaining fame burdens him with pressures that are impossible to overcome and thoroughly destructive. Consequently, he makes decisions impulsively, solidifying his inexorable doom. Unlike Antony, Cleopatra shows herself wholly conscious of the pressures of widespread fame only toward the end of her life when she is contemplating suicide. Before Antony's suicide, she is secure in her royal image and, monofocused, seeks her beloved's approval and devotion. She displays little regard for how the world views her stature, although she is clearly aware of what the Romans think of her. In involving herself in the Battle of Actium, in dealing with Octavius' underlings, Proculeius and Dolabella, and Octavius himself, and in perpetuating the heroic ideal of Antony's fame, she enlarges her consciousness of fame. Consequently, she stages her death with a royal splendor that guarantees a widespread fame concomitant with Antony's, turning potentially deleterious pressures into a triumphant exit from the world.

In her article, "Edward Alleyn, the New Model Actor, and the Rise of the Celebrity in the $1590 \mathrm{~s},{ }^{12}$ S. P. Cerasano gives us another possible 
reason from the theater culture at the close of the sixteenth century why early modern audiences might have been willing to embrace with eagerness a play in which the protagonists were celebrated figures. Cerasano contends that, thanks to the economic stability of permanent playhouses during the 1590s, a fresh relationship between audiences and actors formed. Audiences grew familiar with players who stood out, enabling the creation of "the new model actor," an actor who, because he could be seen repeatedly by a newly created base of fans, could achieve widespread popularity: "the 1590s witnessed the rise of the celebrity player as an unprecedented phenomenon on the London stage." ${ }^{13}$ The first celebrity actor was Edward Alleyn who initially achieved acclaim in the role of Christopher Marlowe's Tamburlaine, an event that soon had repercussions in the management of repertory. According to Cerasano,

it is crucial to acknowledge the ways in which the Tamburlaine craze shaped Alleyn's artistic career, as well as the manner in which Alleyn's continued presence within the Lord Admiral's men molded the Rose repertory for almost a decade. Not least of all, we need to consider the importance of these factors in creating a theatrical culture in which the Rose playhouse, together with the Admiral's Men, became one of the first companies (if not the first company) to participate in the marketing of celebrity actors. ${ }^{14}$

Having worked at the Rose Theatre during Alleyn's heyday, Shakespeare witnessed and participated in the growth of the "fame culture"15 of actors as it developed. Consequently, his audiences, already conditioned to respond with interest to the celebrity status of the historical figures in his dramas, were now also excited by the celebrity status of the actors who played them and eager to see how these actors would portray such figures. The popularity of certain actors also very likely had an influence on Shakespeare in his choice of subject matter and in the way in which he construed it. ${ }^{16}$ Thus, the advent of celebrity actors could only have heightened both his and his audiences' consciousness of and interest in celebrated figures from history. ${ }^{17}$ We might therefore speculate that a wellloved, aging Richard Burbage and a talented, experienced, even reputed adolescent ${ }^{18}$ played Antony and Cleopatra and, because they were celebrities in their own right, drew to the theater people whose anticipation and pleasure were doubled to see how celebrated actors would play celebrated figures from history. What we do not know, of course, is the degree to which the fame of the characters imposed itself upon (i.e., "ghosted") the 
actors or the degree to which the celebrity status of the actors enabled them to impose mannerisms upon (i.e., "ghost") the figures they were playing.

In undertaking a dramatization of private and public elements in the lives of Antony and Cleopatra, Shakespeare had a host of sources to draw from, all of which-for good or for ill-helped to augment and extend their fame. ${ }^{19}$ I realize that making this assertion immediately raises some basic questions of definition about what the notion of "fame" entails. Specifically, what do we mean by fame as Shakespeare might have understood it, and how does it differ from the status of a person in the seventeenth as well as in the twenty-first century whom we would label a celebrity? Why are Antony and Cleopatra now frequently considered the products of fame rather than celebrities? Or can they also be responded to as both? David Giles has carefully explained that the idea of "fame has a long and distinguished history. The term 'kleos afthiton', translatable as 'imperishable fame', can be found in Homer ... Different types of fame have been identified throughout history: fame as immortality, spiritual fame (in the eyes of God), worldly fame (in the eyes of the public) and, more recently, the fame of the moment." ${ }^{20}$ Fame can be meritorious, notorious, or, as in the cases of Antony and Cleopatra, both. Shakespeare uses the noun "fame" in four distinct ways: to mean rumor or report (e.g., Anthony and Cleopatra 2.2.175: "So is the fame" and 3.13.122: "vulgar fame"); renown (e.g., Anthony and Cleopatra 3.1.15: "too high a fame"); reputation (e.g., 1 Henry VI 2.1.16: "he wrongs his fame"); and high praise (e.g., Anthony and Cleopatra 2.6.63-64: "Your fine Egyptian cookery shall have / The fame"). He also uses the word as a verb, meaning "to make famous" (e.g., Henry V 2.4.92: "from his most famed of famous ancestors"); or "to report, repute" (e.g., 3 Henry VI 4.7.26: "Your grace hath still been famed for virtuous"); or "to extol, to panegyrize" (e.g., Troilus \& Cressida 2.3.239-40: "Famed be thy tutor, and thy parts of nature/Thrice-famed beyond all erudition"). ${ }^{21}$ By and large, the playwright's associations with the word are positive; fame seldom appears to be linked in his mind with denigration. In essence, he embraces the several meanings of fame in a variety of applications for the many dramaturgical possibilities it offers. Such possibilities are augmented in Antony and Cleopatra because the renown of the two protagonists is not always based on commendable behavior. Our final attitude toward their fame is rooted in a context in which we are asked not to overlook either their human weaknesses or the impact of the political situation on their decision to take their own lives. Nevertheless, the play does 
leave us with a final positive attitude toward them in the engendering of their fame, reaching its culmination in the portrayals of their suicides, for, in spite of other negative considerations, we are awed by their fortitude and able to interpret their self-imposed deaths as testaments to the depth of their extraordinary bond.

According to the Oxford English Dictionary, the word "celebrity" was first used by Richard Hooker in Ecclesiastical Polity (VII. viii. paragraph 8) in 1600 to mean "the condition of being much extolled or talked about; famousness, notoriety"; the example given is Hooker's assertion, "The dignity and celebrity of mother cities should be respected." Thus, although the term was available for use by Shakespeare, who at thirty-six was only at the midpoint of his career, he showed no inclination to employ it. The word is more commonly used today and, unlike "fame," is almost never ubiquitous and transhistorical in its significance. ${ }^{22}$ As Giles sees it, "celebrities are well-known (through the media) for nothing in particular, whereas the truly famous are in some way deserving of individual recognition." ${ }^{23}$ If this statement seems to suggest that those people who have achieved fame are somehow restricted to the morally deserving, Giles is quick to counter that impression, declaring, "The historical evidence demonstrates quite clearly that fame has, to some extent, always been regarded as essentially amoral and frequently undeserved." ${ }^{24}$ To be sure, Jack the Ripper is famous but not for his wondrously moral feats. And, as we know, Antony and Cleopatra have been both denigrated and extolled, decried as immoral and exalted as demigods.

It is clear that the definitions of fame and celebrity have encompassed moral extremes. One's fame or celebrity status can be rooted in moral or immoral behavior, or in actions whose frame of reference is nonmoral, including actions that are perceived from a purely aesthetic perspective as entertainment. Persons whose achievements do not invoke a moral frame of reference can range from remarkable-a great singer, for example - to unremarkable-for example, wealthy persons of no particular distinction other than their wealth. Those in the latter group have been dubbed, not without mocking irony, "celebutants." In the twenty-first century, we often make the distinction between highbrow celebrities (e.g., Albert Einstein) and lowbrow celebrities (e.g., Paris Hilton), the former being more capable of achieving lasting fame than the latter. Highbrow celebrities such as scientists or composers can require a specialized understanding to appreciate the greatness of their endeavors, and they tend to fit into the affirmative moral category of persons worthy of fame. As we 
shall see, from the perspective of those who have some comprehension of Shakespeare's written texts, this view has become his fate in the twentyfirst century. To be sure, there are other celebrities who merit moral commendation for their achievements, if not their persons, and who are not highbrow; they require nothing more than common knowledge to be credited with renown —as, for example a great humanitarian (e.g., Mother Theresa) or a great athlete (e.g., Jackie Robinson). Sometimes we distinguish between the celebrities and their achievements, and sometimes we do not. But when lowbrow celebrities, such as actors or models who lack talent, mesmerize us, all our reflective powers seem to vanish; we suspend ethical judgments and escape into a cocoon of bemused fantasy.

In distinguishing the psychological differences between our moral and aesthetic responses to famed persons and celebrities, we see that ethical assessments require some degree of detachment and rationality, whereas, usually involuntary, aesthetic responses demand an engaged, strong sensory and emotional reaction. And, of course, the two responses can be intermingled. We react to notorious figures from an inescapably superior ethical position, with a moral disapproval that may or may not be mixed with an aesthetic appreciation. Overall, however, as spectators, we respond with gratification, for we see ourselves as unquestionably superior.

Because moral, immoral, and non-moral perspectives can be evoked in our response to both famed persons and celebrities, the question arises as to what is the crucial difference between the two designations? Giles gets to the heart of the matter when he asserts that fame should "be seen as a process rather than a state of being." 25 Therefore, unless celebrities become part of a process whereby their renown becomes imperishable, they cannot be considered people of fame. The process itself entails a continual recasting of the figures, a perpetual myth making once their acclaim has been generally accepted. The ironic truth is that all famous persons become fictionalized figures as the process develops and the myth making and legendizing grow. Cleopatra demonstrates this tendency after Antony's death when, in speaking with Dolabella, she suddenly bursts forth with reasons for her warrior hero's fame (5.2.70-100). She concludes her hyperbolic encomium with an assertion of Antony's greatness, an estimation that overturns the standard view of the superiority of the artistic imagination over nature: "Nature wants stuff / To vie strange forms with fancy; yet t'imagine / An Antony were Nature's piece 'gainst fancy, / Condemning shadows quite" (5.2.96-99).$^{26}$ Cleopatra's claims are extravagant but her 
language rises to the occasion of her myth making with a superlative tribute. Although Dolabella understands her description as a fantasy, he is clearly captivated by the Queen and genuinely moved by her attempt to compensate for her loss:

Cleopatra: His [Antony's] face was as the heav'ns, and therein stuck

A sun and moon, which kept their course and lighted

The little $\mathrm{O}$, the earth.

Dolabella:

Most sovereign creature-

Cleopatra: His legs bestrid the ocean; his reared arm

Crested the world; his voice was propertied

As all the tunèd spheres, and that to friends;

But when he meant to quail and shake the orb,

He was as rattling thunder. For his bounty,

There was no winter in't; an autumn 'twas

That grew the more by reaping. His delights

Were dolphin-like; they showed his back above

The element they lived in. In his livery

Walked crowns and crownets; realms and islands were

As plates dropped from his pocket.

$(5.2 .78-91)$

The Brobdingnagian sense of Antony as a giant comfortably in tune with nature's largest, most impressive components ("ocean," "world," "tunèd spheres," "orb," "thunder," "winter," "autumn," "realms," "islands"); the grandiloquent expansiveness of the cosmological imagery; the unexpected hyperbolic, ironic detail of kings and princes as "livery" - all characteristics evocative of extraordinary physical and mental prowess-patently raise Antony's fame within the play to the level of a legend, thereby enlarging the possibilities for responding to him and for idealizing him. Dolabella understands Cleopatra's description as a powerful expression of her grief: "Your loss is as yourself, great; and you bear it / As answering to the weight" (5.2.100-01). He is so awed by her person and so struck with sincere compassion at her grief, very likely deepened by his foreknowledge of her fate at the hands of Octavius (5.2.101-9), that he mirrors it with grief of his own ("I do feel / By the rebound of yours a grief that smites / My very heart at root" 5.2.102-4). ${ }^{27}$ The genuineness and honesty of his response set off the legendizing of Antony that the Queen so ebulliently promotes through her imaginative fantasy. At the same time, in understanding the description of Antony as an expression of the authenticity of her love and admiration for her "man of men" (1.5.75), Dolabella's 
response demonstrates Cleopatra's uncanny ability to enthrall her audience even when she is not striving to do so.

In characterizing the legend of Antony that Cleopatra is helping to develop, Linda Charnes comments, "a legend is a cultural product which depends upon the naturalizing or 'forgetting' of its own history as a manufactured thing." 28 Just so; the legends of Antony and Cleopatra are part of a process that continues into the twenty-first century, guaranteeing ad infinitum the imperishability of their afterlives as famed persons. Yet, simultaneously, given the twenty-first century's overwhelmingly pervasive predilection for designating celebrities and thanks to books, movies, television, the internet, and an increasing number of stage versions of the play, ${ }^{29}$ Antony and Cleopatra are also on occasion responded to as if they were celebrities. At times, the shallowness of our response to well-known screen idols such as Elizabeth Taylor and Richard Burton ${ }^{30}$ can induce us to react to the actual Antony and Cleopatra as if they were newly discovered icons. A somewhat lesser shallowness has allowed some people to credit Shakespeare and his works with fame. In both cases, the legendizing continues.

Interestingly, fame and celebrityhood are not restricted to people who have existed as actual, living human beings. ${ }^{31}$ They can also be inhabitants of an initially fictional world. Although Antony and Cleopatra were authentic historical figures, Shakespeare's Hamlet was not; and, yet, he, too, has achieved fame over the course of more than five centuries. As examples outside of Shakespeare, we recognize the notoriety of a Dr. Jekyll and Mr. Hyde and the Frankenstein monster; and at the opposite end of the spectrum a Sherlock Holmes. Again, we see that the determining criterion for fame is whether those being considered are part of a process or simply momentary shooting stars.

Inevitably, in talking about figures who have become famous or who are celebrities, we want to know just how they have achieved their elevated status and precisely what attracts us to them. Neither question affords a quick, let alone a clear answer; nor, in consequence, have all but a few scholars ventured to put their toes into such murky waters. Leo Braudy, whose work, The Frenzy of Renown: Fame \& Its History, is acknowledged by scholars as indispensable, follows the course of famous figures in sociopolitical history and literature from Alexander the Great, the first person to achieve fame, well into the twentieth century. ${ }^{32}$ Braudy is especially detailed in explaining how people in a variety of cultures have achieved fame. Whereas he tends to emphasize the ways in which famous 
figures consciously strive for fame and try to control its course, Linda Charnes focuses on fame as "the property of a cultural marketplace,"33 positing that "identity is socially constituted." ${ }^{34}$ Probably a combination of the two perspectives best characterizes the pathway that fame actually follows. But neither of these perspectives accounts for why we are drawn to famous figures or why we credit them with fame in the first place.

The second of these two queries is easier to answer than the first. Actual or fictional figures who in a specific area lay claim to extraordinary feats (good or bad), who hold what are commonly regarded as important positions, or who manage both simultaneously move into a spotlight that allows them to become celebrated, famously or infamously as the case may be. The feats may be mental, physical, or a combination of the two. Furthermore, Joseph Roach suggests that we may also be attracted by the "it" factor of the person: "There is a certain quality, easy to perceive but hard to define, possessed by abnormally interesting people. Call it 'it." 35 Both Antony and Cleopatra qualify as having "it." More often than not, Shakespeare takes his famed characters from history; thus, whether they have "it" or not, they are elevated to begin with by virtue of their social class and profession or occupation. The playwright has an idea of the audience's preconceived notions of the personages he portrays and uses that knowledge to create specific dramatic effects. In Antony and Cleopatra, for instance, at the outset, in the exchange between Antony's countrymen Philo and Demetrius, Shakespeare plays to his audience's latent pejorative view of the lovers only to spend the remainder of the play challenging and complicating the two Romans' simplistic moralizing, presumably also unsettling a similar stance in his audiences.

We are drawn to the famous, whether or not Shakespeare had a hand in contributing to their reputation, for one or more of several reasons, all involving relatively normal responses, neither neurotic nor pathological: a natural curiosity in discovering something about the private lives of public figures. Because renowned figures are writ large, they may provide the means to a greater understanding of our own selves. We may also wish to compare the actions and psychologies of the famous to ours, whether with regard to their reactions to events in their lives that parallel and support events in ours or to events that set an example of what we hope to achieve. If we desire specifically to alter our behavior, we may be looking for role models to present paradigms for improving our actions, our conditions, or our thoughts about ourselves. The role models can be 
admired for personal ethics, sociomoral values, or both. They may also be perceived as clear patterns to follow for someone interested in becoming famous.

Devotees may believe that scrutinizing famous figures makes them feel important or that they are responding to figures of consequence and, hence, spending their time meaningfully. Moreover, because famous fictional characters and famous actual people are strangers, they enable us to possess enough detachment so that, in theory at least, they can be more or less readily scrutinized. The act of studying them offers us a control that our everyday life rarely allows.

In some cases, the attraction to iconic figures may be a substitute for religious belief. If not, then perhaps the kind of attention shown the iconic figure at least derives from familiar religious practices-in our devotion to a figure that has become a symbol, in standing in awe or wonder before the supposed accomplishments of that figure, and in being able to exalt the figure and enjoy the release from anxiety that the intensity of our devotion brings. ${ }^{36}$ Worship of famed persons is analogous to the worship of religious entities: in our distance from the object of our reverence; in sometimes worshiping a representation of the figure (e.g., religious cross, visual depictions of the person [s], clothing of the celebrity); in desiring to be one with the worshipped object and yet never able to be. The desire to devote oneself to a symbolic representation emerges from a basic desire for the security of a safe, bonded connection and the subsequent need to be immersed in the means toward that connection. The parallel with the motivation of religious worship is unmistakable.

The most widespread and predominant motive impelling our involvement with those who have either justly acquired fame or those who have not but are regarded as celebrities has to be the entertainment provided by the experience. T. S. Eliot maintained that "human kind / Cannot bear very much reality," ${ }^{37}$ that an escape from the pressures and disappointments of everyday reality, Hamlet's "slings and arrows of outrageous fortune," is a psychological imperative. Is our addiction to famed persons and celebrities a result of this behavioral truth? Our fascination with such people provides an absorbing focus that can rescue us from a preoccupation with oppressive events in our life and with ourselves, especially when our reflections upon ourselves produce a continual lowering of our self-image. In our imaginative encounter with the celebrated person(s), we find ample opportunities to cheer ourselves with fantasies; in the process we elevate ourselves, often as an attempt to raise our self-esteem. Further, 
the endeavor may give us a comforting sense of comradeship with others whom we find are similarly inclined.

If the imaginative encounter with renowned persons is specifically that of authors writing creatively about those who have been celebrated, then their fantasizing may well have components that are prompted by the combined desires for both an aesthetic and a commercial success. Since such writers very likely understand that fame is a process and that they are part of it, they probably consciously want to put their mark on the process, thereby raising their own stature even if not always that of the people they are writing about. Concomitantly, they must also realize how marketable their portrayal of famed figures can be. Shakespeare stands out as a case in point. In writing about well-established famous figures from both English and Roman history, he continues the process of extending their fame, not overlooking defects in their characters, personalities, and actions, while at the same time providing a means of personal financial success and enhancing his reputation in his theatrical community. As a result, he not only plays a role in enabling the characters in his plays to achieve an imperishable fame, but also achieves for himself a reputation that has grown into an exalted fame he could not have imagined. However, in being celebrated while he was still living, the first stages of the process had undoubtedly begun.

Understandably, playwrights can experience intense elation when, seized with the heady notion of playing God, "their imagination bodies forth / The forms of things unknown ... Turns them to shapes, and gives to airy nothing / A local habitation and a name" (A Midsummer Night's Dream 5.1.14-18). Like other dramatists (not to mention storytellers in other genres), Shakespeare probably felt a godlike omnipotence as he peopled his plays, devised the action of the plots, and orchestrated the flow of time. Playing God can be utterly enticing; it achieves its most potent degree of absoluteness when the characters are acknowledged as longstanding celebrities. The audience already knows that the persons depicted are of elevated status and of true historical significance, so they come to the theater expecting the playwright to enhance or deflate them. As we have just seen, a side effect of the audience's preconceptions is that the playwright's subjects automatically garner some acclaim for its author even before the play begins because of his boldness in attempting to write something fresh and interesting about well-known persons. In the case of Antony and Cleopatra, Shakespeare meets the challenge he has imposed upon himself by focusing more on the personal bond of love between 
the two protagonists than on their political activities. Moreover, even though the setting is (loosely) historical, it does not impose limits on Shakespeare's imagination; nor would it have prevented him from sensing a self-importance in manipulating the speech and actions of those who had achieved fame or notoriety before he set pen to paper; and, of course, part of the feeling of importance would have stemmed from reconfiguring the milieu of the world the characters lived in.

In an intriguing, in-depth discussion of Shakespeare's sense of aesthetic autonomy, Stephen Greenblatt disavows the playwright's understanding of such a concept as we know it. ${ }^{38} \mathrm{He}$ suggests that Bottom's dream (A Midsummer Night's Dream 4.1.203-12), "This vision of the indescribable, the uninterpretable, the inconceivable ... is the moment in Shakespeare's theatrical works in which he comes closest to the idea of aesthetic autonomy." ${ }^{39}$ Bottom wants Peter Quince to write a ballad of the dream, to be sung before Duke Theseus. Its only function is pleasure. This passage, in conjunction with Puck's epilogue, indicates, "Shakespeare chose to imply that his art had no use-value whatever. It functioned only to give pleasure." ${ }^{40}$ But in The Tempest, Prospero's epilogue suggests the opposite: "where Puck had excused the play's limitations by comparing them to the bad dreams that members of the audience might have had, Prospero invokes the crimes that they might have comitted."41 Greenblatt accounts for "the distance between these two positions" "in Shakespeare's growing skepticism about the claim for autonomy ... or rather a developing sense that the cost of this claim was too high," ${ }^{2}$ concluding that "the shift we see from 'dream' to 'crime' is a measure of his deepening awareness of the nature of his craft and the risks it entailed." ${ }^{43}$ Not surprisingly, Greenblatt's argument reflects a subtlety and intelligence that are unassailable. However, I would add one other piece of evidence to suggest that Shakespeare's understanding of aesthetic autonomy is conceptually clearer than Greenblatt suggests. In a well-known passage from Hamlet, Shakespeare, through Polonius's petty fastidiousness, subverts the premise that the standard categorizations of genre by contemporary theorists of drama are rooted in a sound principle of classification. The playwright concludes his parody with an opposition between drama that is written according to classical or neoclassical rules ("the law of writ") and drama, like his own, composed with a freedom that is able to disregard such rules ("the liberty"): 
The best actors in the world, either for tragedy, comedy, history, pastoral, pastoral-comical, historical-pastoral; scene individable, or poem unlimited. Seneca cannot be too heavy, nor Plautus too light. For the law of writ and the liberty, these are the only men.

(Hamlet 2.2.339-44)

As Greenblatt points out, there is no such thing as absolute autonomy. Even so, this passage suggests Shakespeare's clear awareness of an independence that allows him to break the rules. Furthermore, it gives him a license to act with bold imagination in the language, structure, and characterization of Antony and Cleopatra, to enjoy extending the limits of aesthetic autonomy as far as he can.

During the course of his discussion of Shakespearean autonomy, Greenblatt cites lines from Antony and Cleopatra to support his speculation on the nature of the audiences for whom Shakespeare was writing. Specifically, he finds in Cleopatra's exchange with Iras (5.2.206-25) an identification between a segment of Shakespeare's audiences and "the shouting varletry" of Rome (5.2.55)..$^{44}$ The Queen envisions the degrading actions of "saucy lictors" and the inferior aesthetics of those who attempt to mock her, her fellow captives, and Antony:

\section{Saucy lictors}

Will catch at us like strumpets, and scald rhymers

Ballad us out o'tune. The quick comedians

Extemporally will stage us, and present

Our Alexandrian revels. Antony

Shall be brought drunken forth, and I shall see

Some squeaking Cleopatra boy my greatness

I'th'posture of a whore.

(5.2.213-20)

Greenblatt also contrasts Cleopatra's imagined public performance by the Romans to the earlier one in Alexandria, reported by Octavius, who, in his eagerness to censure it, fails to see that it contains in its full regal display a symbolic significance. I would add that Octavius fails to comprehend that this kind of ritualistic spectacle gives luster to the imperishable fame of Antony and Cleopatra; in having Octavius report it, Shakespeare intensifies the irony of the triumvir's shortsightedness, as well as the gloriousness of the occasion: 
I'th'market-place, on a tribunal silvered, Cleopatra and himself in chairs of gold Were publicly enthroned; at the feet sat Caesarion, whom they call my father's son, And all the unlawful issue that their lust Since then hath made between them. Unto her He gave the stablishment of Egypt, made her Of lower Syria, Cyprus, Lydia, Absolute queen. (3.6.3-11)

Dressed in "th'habiliments of the goddess Isis" (3.6.17), Cleopatra is fully conscious of the significance of her iconic presence, making, as Greenblatt says, "her most extravagant performance, her apotheosis." ${ }^{5}$ "The identification with divinity was part of what it meant to claim to be an 'absolute queen." ${ }^{46}$ The standard of measure Cleopatra suggests in her contemplation of inferior Roman mockery can be contrasted with this illustrious performance in Alexandria and other performances in which she has some control and a strong sense not only of her superiority as a role player but of the significance of her actions - in particular, her assertion of her dignity and majesty in her roles as ruler and exceptional human being. Her first meeting with Antony and the preparations and suicide that immediately follow her final exchange with Iras (5.2.206-25) can be understood as additional instances. In her self-awareness and self-regard, Cleopatra seeks semi-divine stature.

The public ceremony in Alexandria also makes indelible the depth of Antony's bond of love and his authenticity as a "mine of bounty" (4.6.33). In Act 1, Alexas brings a message to Cleopatra from Antony, saying that, in addition to the pearl he is sending her, he promises "To mend the petty present" and "piece / Her opulent throne with kingdoms" (1.5.47-48). His assertion may at first seem the extravagant sweet talk of a nostalgic absent lover. But in Alexandria, he turns his seeming hyperbole into a reality, making literal what at first appeared merely figurative. The ceremonious nature of the occasion not only lends it and its participants seeming omnipotence but enhances their personal fame as exemplars of human mutuality and their importance as historical political figures, both of which, as symbolic gestures, Octavius fails to perceive in his angry, trivializing reduction of their love to lust. Throughout the play, Octavius is so self-focused that he lacks the ability to understand the full range of Antony's personal and professional superiority and, more especially, the 
exceptional characteristics of Cleopatra. Both the triumvir and the Queen are figures destined to reside in the international pantheon of fame and, as such, the significance of their identities can be neither exclusively literal nor even narrowly representational. Partly because of their self-representation, independently and as bonded lovers, they cannot help but embody at times an idealized symbolic meaning in their private and public actions. These meanings take the form of remarkable displays, extraordinary exertions of personal, political, or military power. Moreover, the two protagonists' significance, individually and as a mutual pair, is always in flux and elastic, capable of becoming expansively and ideally representational but only every so often. Antony and Cleopatra's evolving relation to their sociopolitical milieu makes constant this ever-changing condition.

We have seen in this chapter that, in his uses of the word "fame" and in his depiction of famous historical figures, Shakespeare reveals an interest in fame that is less conceptual than pragmatic and less moral than situational (i.e., purely aesthetic). In his preoccupation with the standards involved in measuring up, so frequently on the tongues and in the thoughts of his characters, he reveals his understanding of the attributes of the process of becoming famous. It is to this preoccupation as it is dramatized in Antony and Cleopatra that we now must turn.

\section{NOTES}

${ }^{1}$ See Franklin M. Dickey, Not Wisely But Too Well: Shakespeare's Love Tragedies (San Marino: Huntington Library, 1957), pp. 144-76, for detailed descriptions of "classical and medieval authorities, Elizabethan moral philosophers, and the Senecan playwrights" (p. 175), including Shakespeare's contemporary playwrights, who denigrated Antony and Cleopatra. Dickey is an example of someone who so strongly endorses a moralistic reading of the play that he misses a good bit. But he does present solid evidence for concluding that the prevailing view toward the lovers was harshly condemnatory when Shakespeare wrote the play. For evidence from a major poet contemporary with Shakespeare, see the discussion of Edmund Spenser's views in Chapter 4.

${ }^{2}$ For a discussion of writers who help to fabricate the fame of Antony and Cleopatra, one that takes into account Horace, Chaucer, Plutarch (including North's 1579 translation), Spenser, and sixteenth-century dramatists, see Spevack, A New Variorum, pp. 384-611; Adelman (Chapter 2: "The Common Liar: Tradition As Source in Antony and Cleopatra"), pp. 53-101, and Bevington, Antony and Cleopatra, pp. 4-12. For a later brief summary of such writers, see Stacy Schiff, Cleopatra: A Life (New York: Little, Brown, 2010), pp. 297-301. I include 
Plutarch in the group of fabrications because he draws conclusions at times that are speculative rather than factual.

${ }^{3}$ Coriolanus either continues or supports the public interest in Roman subject matter. Scholarly consensus puts the composition of Coriolanus after that of Antony and Cleopatra, but there is no hard evidence to verify this guess.

${ }^{4}$ Sir Philip Sidney, "An Apology For Poetry" (1595) in The Golden Hind (rev. ed.), ed. Roy Lamson and Hallett Smith (New York: W. W. Norton, 1956), p. 285.

5 Joseph Roach, “The Doubting Thomas Effect," PMLA 126, no. 4 (2011): $1127-30$ at 1128 .

${ }^{6}$ Roach, "Doubting Thomas," p. 1128.

${ }^{7}$ For a discussion of the sixteenth century's growing sense of fame as a means of countering the finality of death, see Theodore Spencer's Death and Elizabethan Tragedy (New York: Pageant Books, 1960), pp. 43-46.

${ }^{8}$ Antony demonstrates his awareness in $1.1 .48-49 ; 1.3 .42-43 ; 3.11 .13-15$ and $60-61 ; 3.13 .17$ and $20-21 ; 4.2 .27-30 ; 4.8 .19-22 ; 4.12 .48$; and 4.14.1-14, 35-36, and 46-49 (the scene in which Antony commits suicide). Cleopatra shows her awareness in 1.5.28-30 and 75-77; 2.5.113-15 and 3.3.26-28 (the scene in which she's curious about Octavia's age); 3.13.189-91; 4.8.17 (where she pinpoints Antony's “infinite virtue”); 4.15.61-93 (where Antony dies and she first contemplates suicide); and 5.2.1-2 and 274-76 (the scene in which she commits suicide).

9 The same could be said of Octavius, Pompey, and Enobarbus, although the chief focus is clearly on the two protagonists.

${ }^{10}$ Antony's heroic nature has already received a highly praiseworthy, detailed description from Octavius in 1.4.57-72.

${ }^{11}$ Whether one looks to dramas such as Christopher Marlowe's Dido, Queen of Carthage, Daniel's Cleopatra, and even lost plays such as Peele's The Turkish Mahomet and Hiren the Fair Greek and Hester and Abasuerus and Greville's Antony and Cleopatra, or to poetry such as Spenser's The Faerie Queene, or to a prose romance such as Sidney's Arcadia, the evidence is abundant. We know as well that the conflict continues as a popular source for literature because of Dryden's All For Love. See my comments in Chapter 2 where I discuss this dichotomy in the contexts of various influences on Shakespeare.

${ }^{12}$ S. P. Cerasano, "Edward Alleyn, the New Model Actor, and the Rise of the Celebrity in the 1590s," Medieval and Renaissance Drama in England 18 (2006): 47-60.

${ }^{13}$ Cerasano, "New Model Actor," p. 47.

${ }_{14}$ Cerasano, "New Model Actor," p. 50. For additional commentary on Allyn's status as a celebrity-in particular, the uniqueness embodied in "the majesty of his style" (p. 55) and "the shape-changing variousness" (p. 55) of his roles-and the ways in which, given his fame, he transformed "the art of playing" (p. 55), see Lawrence Manley and Sally-Beth MacLean, Lord Strange's Men and 
Their Plays (New Haven, CT: Yale University Press, 2014), pp. 54-59. One can only imagine and wonder at the talent of the actor who first played Cleopatra.

${ }^{15}$ Cerasano, "New Model Actor," p. 56.

${ }^{16}$ Andrew Gurr in The Shakespearean Stage discusses two famous comic actors, Will Kempe and Robert Armin, and Shakespeare's having had Kempe in mind when he wrote the parts of Falstaff and Dogberry and Armin in mind for the roles of Feste and Lear's Fool (pp. 108-9). Gurr also discusses Edward Alleyn and Richard Burbage as "famous tragedians" (pp. 109-11).

17 The increasing awareness of celebrity appeal extended, of course, beyond dramatized myths about famous historical figures and actors. One could even include the emergence of a celebrity playwright in his various associations with the theater inadvertently begun in Robert Greene's well known, contemporary characterization of Shakespeare as "an upstart crow."

${ }^{18}$ In an article entitled, "How Old Were Shakespeare's Boy Actors?" (Shakespeare Survey 58 [2006]: 220-46), David Kathman concludes from the available evidence that "until the early 1660 s, female roles on the English stage (including the most demanding, complex parts) were played by adolescent boys, no younger than twelve and no older than twenty-one or twenty-two, with a median of around sixteen or seventeen" (p. 220).

${ }^{19}$ For an examination of such sources, see Robert A. Logan, “'High events as these': Sources, Influences, and the Artistry of Antony and Cleopatra" in Deats, New Critical Essays, pp. 153-74.

${ }^{20}$ David Giles, Illusions of Immortality: A Psychology of Fame and Celebrity (London: Macmillan, 2000), p. 3.

${ }^{21}$ The different definitions of fame are catalogued in Alexander Schmidt's Shakespeare's Lexicon, 3rd ed. revised and enlarged by Gregor Sarrazin (New York: Benjamin Blom, 1968).

${ }^{22}$ For a contemporary definition of "celebrity," see Chris Rojek, Celebrity (London: Reaktion Books, 2001), pp. 9-10.

${ }^{23}$ Giles, Illusions of Immortality, p. 4. For additional commentary on the origins and definitions of "fame" and "celebrity", and for suggestions about why the two concepts are (increasingly) unable to be separated, see, in the special issue of PMLA 126, no.4 (2011), with its focus on celebrity, fame, and notoriety, the essay by Joseph A. Boone and Nancy J. Vickers, "Introduction-Celebrity Rites," pp. 903-4. The writers declare that, "In the twenty-first century, the immortality of traditional fame has taken a back seat to the incandescence of celebrity" (p. 904).

${ }^{24}$ Giles, Illusions of Immortality, p. 4.

${ }^{25}$ Giles, Illusions of Immortality, p. 4.

${ }^{26}$ In a footnote, Stephen Greenblatt, Shakespeare's Freedom (Chicago: University of Chicago Press, 2010), pp. 136-38 n. 20, comments on this passage. Although his context differs from mine, he also believes that, in considering the Sidneyesque argument for the superiority of the imagination over nature, 
"Cleopatra turns the argument on its head" (p. 101). See also Ronald R. MacDonald, "Playing Till Doomsday: Interpreting Antony and Cleopatra," English Literary Renaissance 15 (1985): 93-95; like Greenblatt, MacDonald discusses Cleopatra's inversion of the standard dichotomy of imagination and nature; but he uses the passage primarily to suggest that, if Shakespeare could imagine "a nature possessed of imagination," then, instead of making theater historical, he could see "that history may be fairly called theatrical" (p. 95).

${ }^{27}$ Dolabella later returns to warn Cleopatra of Octavius Caesar's intentions, and it is clear that he has been captivated by her, perhaps even fallen in love with her-but without the Queen's intending to entice him: "Madam, as thereto sworn by your command, / Which my love makes religion to obey, / I tell you this" (5.2.198-99; my italics).

${ }^{28}$ Linda Charnes, Notorious Identity: Materializing the Subject in Shakespeare (Cambridge, MA: Harvard University Press, 1993), p. 2.

29 The most recent books are the already footnoted biography of Cleopatra by Stacy Schiff (Cleopatra: A Life) and a historical account of both Antony and Cleopatra: Adrian Goldsworthy, Antony and Cleopatra (New Haven, CT: Yale University Press, 2010). In 2010 alone, there were at least eight professional stage versions of the play: Irina Tsikurishvili and Ben Cunis at the Syntic Theater (Washington, DC); Kathryn Hunter and Darrell D'Silva at the Courtyard Theatre (Stratford-upon-Avon); Kelly Meg Brennan and Dan Walker at the Road Less Traveled Theater (Buffalo, NY); Jennifer Lines and Dan Wheeler at Bard on the Beach (Vancouver); Kim Cattrall and Jeffrey Kissoon at the Liverpool Playhouse; Susie Trayling and Owen Oakeshott at the National Theatre, London, and Kate Mulgrew and John Douglas Thompson at the Hartford Stage (Hartford, CT).

${ }^{30}$ Or Angelina Jolie and Mark Hildebrandt, rumored to be the next cinematic twosome to take on the roles of Cleopatra and Antony.

${ }^{31}$ See Anderson, "Celebrity Shylock." Her essay "proposes the celebrity of fictive bodies and seeks to understand how, and how far, certain fictional characters can stimulate an audience response analogous to that elicited by the flesh and blood" (p. 936). As the title of the article indicates, Shylock is her example and she pinpoints the eighteenth century as the period in which the fascination with celebrity culture took shape and intensified.

${ }^{32}$ Leo Braudy, The Frenzy of Renown: Fame \& Its History (Oxford: Oxford University Press, 1986).

${ }^{33}$ Charnes, Notorious Identity, p. 4.

${ }^{34}$ Charnes, Notorious Identity, p. 14.

35 Joseph Roach, It (Ann Arbor, MI: The University of Michigan Press, 2007), p. 1.

${ }^{36}$ In his book Celebrity, Chris Rojek has a chapter entitled "Celebrity and Religion" that, although it concentrates primarily on celebrities and not necessarily those who have achieved fame, contains some suggestive parallels between the worship of celebrities and religious worship, especially pp. 74-78 where he 
discusses "Elevation," "Magic," and "Immortality" as "Celebrity Ceremonies of Ascent."

37 T. S. Eliot, Four Quartets, "Burnt Norton," Part I.

${ }^{38}$ Greenblatt, Shakespeare's Freedom. The chapter in question is entitled "Shakespearean Autonomy" (pp. 95-123).

${ }^{39}$ Greenblatt, Shakespeare's Freedom, p. 119.

${ }^{40}$ Greenblatt, Shakespeare's Freedom, p. 121.

${ }^{41}$ Greenblatt, Shakespeare's Freedom, p. 122.

${ }^{42}$ Greenblatt, Shakespeare's Freedom, p. 122.

${ }^{43}$ Greenblatt, Shakespeare's Freedom, p. 123.

${ }^{44}$ Greenblatt, Shakespeare's Freedom, p. 100-101.

${ }^{45}$ Greenblatt, Shakespeare's Freedom, p. 101.

${ }^{46}$ Greenblatt, Shakespeare's Freedom, p. 101. 

Chapter 4

\section{Standards of Measure in Antony and Cleopatra}

Judge not, that ye be not judged. For with what judgment ye judge, Ye shall be judged; and with what Measure ye mete, it shall be measured To you again.

Matthew 7:1-2

Viewed from a perspective usually overlooked, we find that Antony and Cleopatra dramatizes the difficulty and yet the necessity of measuring up to self-styled standards. Ultimately, everyone's standards are self-styled, the mind's filtered product of genetic and cultural influences, as well as environmental conditions. The characters in the play encounter "difficulty" measuring up, because they are subject to a complex of challenges from within and from without, whether in their attempts to set fixed standards for themselves or for others. The challenges from within derive from psychological limitations. The challenges from without include seen and unforeseen, constantly changing restrictions that persist in complicating and impeding the characters' attempts to measure up. Hampered internally by his impulsiveness, confusion, and misperceptions and externally by the sociopolitical limitations imposed upon him, Antony struggles to measure up to his public roles as warrior leader and triumvir and to his private roles as lover and husband. Cleopatra's standards and goals, primarily personal, are all-too-narrowly focused. They shift considerably, however, as she realigns herself with Antony (3.6.1-39) and moves toward suicide, but her change in perspective is still conditioned by an intense single-mindedness. Throughout the play this trait proves as much a weakness as a strength. In addition, she is indirectly subject to the restrictive force of Roman politics. In anticipation of her first meeting with Antony, she apparently senses a need to measure up as an alluring figure 
of royalty, presumably to enlist him as a political ally, but soon after as a beguiling lover who needs continually to convince him to remain with her in Egypt. However, her incessant endeavors to assert some control over his whereabouts are unable to counter the political and military pressures from Rome. Thus, he yields to them - that is, until he deserts Octavia and breaks off relations, both personal and political, with his brother-in-law and fellow triumvir. If Cleopatra's focus almost always centers on securing her bond with Antony, his constantly alters as he tries to satisfy the insurmountable conflicting demands of both his professional and private lives.

Each lover also encounters "difficulty" measuring up because of crippling misperceptions. For example, Cleopatra's single-minded belief in the superiority of a bonded love providing intense personal pleasure and a euphoric sense of fulfillment becomes a major cause of her short sightedness ${ }^{1}$ and, momentarily, Antony's as well when, to legitimize his present life in Egypt, he parlays his genuine concern with his mortality into a strong, defensive pronouncement: since "Kingdoms are clay" (1.1.37), "The nobleness of life / Is to do thus" (1.1.37-38). This defiant statement might be more credible were Antony not a triumvir and commander of military forces. His impulsiveness and tendency to react rather than to act (especially with Cleopatra) frequently account for his misperceptions; they prevent him from facing his major dilemma, and, even though it cannot be resolved, attempting to find a satisfactory way of coming to terms with it. For instance, having impulsively just agreed to marry Octavia for the purpose of political stability and unity, Antony consults the Soothsayer who issues a dire warning: in spite of the marriage, the two triumvirs will always remain in contention; moreover, the luck is all on Caesar's side and his fortunes will invariably rise higher. Antony acknowledges the truth of the Soothsayer's observations but, instead of letting the truth spur him to action, utters an impulsive, confused response, briefly subverting his professional to his private desires: "I will to Egypt; / And though I make this marriage for my peace, / I'th'East my pleasure lies" (2.3.38-40). Inextricably linked to the lovers' defects in perspective is the conflict of cultures that they are forced to participate in: the explicit and implicit sociopolitical demands of Rome and the apparent credo in Egypt that accommodating the pleasures of one's personal life takes precedence over matters of state.

The "necessity" to measure up results from a combination of genetic forces, including the aging process, cultural influences, and conditions imposed by environments, over which the mysterious workings of fate 
hold sway. The play is overwhelmingly concerned with characters expressing an inherent need to measure up; they are engrossed in applying standards of measure to themselves and to others, usually to the discredit of the latter. This ingrained desire does not mean that the drama's personae gauge their success by how well they meet the standards of an external model or stereotype even if they are aware of others' judgments against them. As Julian Markels points out, "Again and again in the play, the characters worry about falling away from, not 'bias of nature,' some prior external category, but themselves, in all their internal definition." 2 Part of what complicates the "internal definition" for most of the five chief figures in the play is their awareness of the standards needed to measure up in order to live their lives successfully as iconic historical figures. None of the characters expresses this awareness more blatantly than Antony, Cleopatra, and Octavius, although, to a lesser extent, Enobarbus and Pompey can also be included. All five express a consciousness of their status as part of the permanent record of history, even if Pompey's awareness is largely implicit; he is usually more focused on how past history has shaped the present than on how the present will shape the future (e.g., 2.6.8-23). This group of characters stands in contrast to Octavia who has no aspirations for herself unless some small hope of becoming an effective mediator; as she says plaintively to Antony when discussing the hostility between him and her brother: "The Jove of power make me, most weak, most weak, / Your reconciler" (3.4.29-30). Because all five of the major figures are, to varying degrees, interested in managing their images, both during their lives and for future generations, their acts of measuring up involve a constant re-examination, if not a re-creation, of their self-worth and, hence, their identity.

Seen from the perspective of a reader or a viewer, the double awareness of characters who take responsibility for their worldwide self-image for posterity as well as during their existence, intensifies the drama's focus on measuring up. Mark Rose has identified what we might view as another element of intensification in noticing that the word "becomes" appears more often in Antony and Cleopatra "than in any play of Shakespeare's except The Winter's Tale, which is also concerned with process." ${ }^{3}$ In its various uses, the word reveals the protagonists' consciousness of measuring up to an image of themselves that is inevitably susceptible to change. Because the play follows Antony's reputation during the last ten years of his life and after, Antony suggests most clearly the ligature between measuring up in life and the conditions and process of achieving an 
imperishable fame. By the time she commits suicide, Cleopatra also learns to value the full range of imperishable fame, both for Antony and for herself.

From within the world of the play, viewed through the eyes of the characters, standards of measurement are employed variously in attempts to achieve momentary satisfaction, long-term fulfillment, a sense of power and superiority, idealized notions of behavior, or some combination thereof-whether as a heroic commander of warring forces, an omnipotent triumvir, a captivating tributary queen, a devoted lover, an effective mediator, or a dedicated attendant and friend. During the course of the drama, Antony, Cleopatra, Octavius, Enobarbus, and Pompey (again, implicitly, e.g., 2.7.69-76) employ their consciousness of standards to assert some control over their public, historical images and, hence, their reputations after death.

Viewed from a detached perspective outside of the play, we see that a drama in which already famous characters actively apply standards of measurement to themselves and to others contributes to our understanding of the process of sustaining an imperishable fame in two ways: First, the play depicts the mechanics of the process, presenting us with multiple instances of the standards being invoked, but, most especially, those standards able to produce "high events" (5.2.354), "past the size of dreaming" (5.2.96), worthy to "earn ... [a] ... chronicle" (3.13.179), "a nobleness in record" (4.14.99). Second, the drama adds to the continuum of Antony and Cleopatra's fame one more impressive depiction of their behavior as celebrated historical icons. Shakespeare individualizes the depiction in part through the protagonists' strong consciousness of their iconic status and their ability to nourish their acclaim not only while they live but after they die.

Moreover, Shakespeare invests his dramatization of measuring up and achieving enduring fame with complexity through the well-documented ambiguities of language, characterization, and action. ${ }^{4}$ As Ronald R. MacDonald puts it, Shakespeare's primary concern is "with meanings and the way interpretive energy plays over the infinitely ambiguous world, constructing it and reconstructing it in imagination." The play demands from an audience a flexibility of imagination that thrives on ambiguity and eschews a need to arrive at a knowledgeable conclusiveness. Later in the same article, MacDonald offers a related argument. Citing Cleopatra's imagined profile of Antony soon after he has left for Rome (in 1.5.18-50), he finds that it "points toward a standard in the imaginative faculty that 
transcends our normal sense of measure and fact." ${ }^{6}$ Indeed, Cleopatra's imagination overturns all conventional expectations and inscribes itself in both her words and actions. It is one of the characteristics that most awes us in our response to her and, ultimately, in our response to Shakespeare, her maker. Both of MacDonald's assertions lead to his main point: using Enobarbus as an example, he first argues that the soldier "does not yet know himself." $\mathrm{He}$ then explains the cause in more generalized terms, "the inner world of feeling, as well as the outer world of things, is always more complex than our formulations about it"; ${ }^{8}$ this is so, he contends, because "reality has more meanings than language can easily dispose of." This perception applied to the play as a whole helps to explain the difficulty encapsulating reality that the main characters encounter as they attempt to measure up and seek permanent fame. But it is a difficulty that makes the endeavor all the more praiseworthy. In addition, it helps to account for the seemingly endless fascination of viewers, readers, and scholars who, up to the present day, continue to find the overwhelming number of ambiguities in the play spellbinding.

Throughout Antony and Cleopatra, Shakespeare further complicates the staging of his characters' attempts to live by self-created standards by portraying the knotting up that takes place when their public and private lives intersect. As every audience member and reader of the play knows, Antony gives the fullest expression of one caught in the wrenching throes of conflicting public and private demands. Paradoxically, his being caught in this crossfire impedes his ability to perform actions that would bring him additional praise, but, at the same time, it extends his fame, because, since his tribulations are those of an eminent figure, they continue to fascinate readers and viewers and deepen their impressions of him. One of the most intense scenes in which Antony realizes his inability to measure up occurs after his flight from the sea battle at Actium (3.11) when the conflict between his public and private desires has evoked his deepest feelings of humiliation. To his attendants, he speaks of the effects but not the causes of his failure as a military commander: "Hark! The land bids me tread no more upon't; / It is ashamed to bear me. ... / I am so lated in the world that I / Have lost my way forever" (3.11.1-4). Examining the causes might have ultimately been more beneficial. Instead, he imagines that the land, naturally opposed to the sea, rejects him for fleeing while fighting at sea. In using the phrase "in the world," he implies that he measures his public image as a famous, universally regarded figure and role model. He sustains this standard of measure when he complains to 
Cleopatra, repeating his awareness that he is on the world's stage, "Now I must / To the young man send humble treaties, dodge / And palter in the shifts of lowness, who / With half the bulk o'th'world played as I pleased, / Making and marring fortunes" (60-64). Guilt-ridden, Antony feels that he deserves to be shunned for not remaining true to his nature: "Let that be left / Which leaves itself" (3.11.19-20). By the end of the scene, when he pardons Cleopatra, we are left to wonder exactly what he considers his true nature to be and if it can be as simply defined as he implies. His selfrecrimination here is magnified because of his statements of self-loathing: "I have fled myself, and have instructed cowards / To run and show their shoulders" (3.11.7-8) and in his confession to Cleopatra, "I have offended reputation, / A most unnoble swerving” (3.11.48-49). Evidently, he sees himself as an iconic role model who has disappointed those who look to him for exemplary guidance. In addition to measuring himself against a personal, ethical set of ideal Roman values, he puts his shame for his ignoble behavior into the universal, transhistorical context of mutability: "My very hairs do mutiny, for the white / Reprove the brown for rashness, and they them / For fear and doting" (3.11.13-15); he suggests in his moralizing fit of self-laceration that age should have taught him not to act impetuously out of "fear and doting." In its connotative effect, the metaphor of aging adds a grim psychological awareness that change is brutally unforgiving in allowing opportunities to rectify such errors; we have seen the dread of mutability weighing on Antony since the first scene of the play. Here, it compounds his misery. However he construes it, Antony's standard of measure is rooted in authoritative moral abstractions and is unswervingly public - undoubtedly the influence of his Roman upbringing and similar to the manner of speaking by the other Romans in the play. But, as Shakespeare is well aware, generalized moral abstractions can lose their footing in particularized, psychological situations. Thus, at the end of the scene, Antony's moralistic standards of measure crumble in the face of his overwhelming passion for the weeping Cleopatra: "Fall not a tear, I say; one of them rates / All that is won and lost. Give me a kiss. / Even this repays me" (3.11.68-70). This contradictory response, personal in nature, undermines the public standard of measure that Antony has spent a lifetime adhering to and through which he has achieved an extraordinary fame. It also casts skepticism on the worth of measuring up as a rational activity.

After whipping Thidias, Antony tells the emissary to return to Caesar with the following impassioned message: 
Look thou say

He makes me angry with him; for he seems Proud and disdainful, harping on what I am, Not what he knew I was. He makes me angry, And at this time most easy 'tis to do it, When my good stars that were my former guides Have empty left their orbs and shot their fires Into th'abysm of hell.

(3.13.144-51)

Antony's consciousness of his fame could not be clearer. He admits his fury, all too innocently mentioning his current vulnerability to anger. His rage is directed at what he probably accurately perceives as Caesar's pride and disdain in overtly mocking his fallen state. Then, with a touch of self-pity and desperation that lead him to shift the blame speciously but eloquently away from himself, he declares that ill fortune has determined that his present actions lack the stature of his past actions. Most striking here is that at this point he appears to have a confused, unrealistic notion of human response-namely, that his past heroic feats should and will compensate for his present slackening. That this response is excessively idealistic, the product of a fantasy, may seem clear when, during the course of the play, we compare it to the actual negative judgments of Philo (in 1.1), Octavius (in 1.4, and later, after 3.4), Enobarbus (in 3.10 and 3.13), and those other followers who leave the hero when his situation seems hopeless. For Antony, this seemingly naive, optimistic hope defines the essential meaning of fame: one's renown is not that "which alters when it alteration finds" (Sonnet 116, 1.3) but that which, ideally, sustains itself even when the "orbs" are empty. It is not until his death and after that we are jolted into the realization that he has, in fact, managed to make this apparently hyperbolic idealization an actuality.

If we shift our focus to the playwright himself, we discover a parallel: in attributing the suicides of Eros, Cleopatra, and Charmian and the deaths of Enobarbus and Iras to personal loyalty, Shakespeare shows that, like Antony, he is attempting to transform an ideal into a reality. $\mathrm{He}$ romanticizes sustained devotion as a standard of measure that is an essential ingredient of the fame of the two lovers: Cleopatra is unwavering in her faithfulness to Antony, and he is exceptional in his ability to inspire devotion not only in Cleopatra, Fulvia, and Octavia but also in his soldiers and servants. This characteristic accounts for a major ingredient in delineating fame as Shakespeare shapes it and whether seen as a positive 
or negative attribute in the relationship between the lovers, it has become a major element in their continuing fame. In Romeo and Juliet the playwright constructs the plot so that each lover dies as a testament of loyalty to the other. In Antony and Cleopatra, history provides a parallel, symmetrically enhanced by Shakespeare: Enobarbus, Eros, and Cleopatra (in large part) die for love of Antony; and Iras, Charmian, and Antony (in large part) die for love of Cleopatra.

Antony invokes this same idealistic perspective as he is dying; with his customary good cheer, confidence, and pride-astonishing given the situation-he instructs Cleopatra personally in the mechanics of promoting his lasting fame:

\author{
The miserable change now at my end \\ Lament nor sorrow at, but please your thoughts \\ In feeding them with those my former fortunes, \\ Wherein I lived the greatest prince o'th'world, \\ The noblest; and do now not basely die, \\ Not cowardly put off my helmet to \\ My countryman-a Roman by a Roman \\ Valiantly vanquished.
}

$(4.15 .53-60)$

The consoling directive to Cleopatra does not suggest explicitly that she trumpet the fame of his "former fortunes" to the world but, given her utter devotion to him and belief in his greatness, her remarkably fertile imagination and uninhibited theatrical personality, and her consciousness of her image as Queen of Egypt and an historical icon, it is inconceivable that she would keep her knowledge of "the greatest prince o'th'world" solely to herself. Antony's death enlarges and heightens her own sense of the imperishability of fame, and it continues to increase as she contemplates her suicide.

Until the end of the play, both for good and for ill, Cleopatra remains faithful to her personal desires, although she also has to deal with the consequences of Antony's struggles between the conflicting forces of his public and private worlds. Her sense of measuring up not only determines the roles she plays in her attempts to draw Antony to her and to keep him by her side, but she continues to measure up to the roles she adopts once Antony dies. Because we often witness her investment in displaying the dignity and aesthetics of royalty that accompany her imperial role as a queen, we understand that, for her, style in assuming roles is often an essential ingredient. ${ }^{10}$ In her most well-known role, orchestrating her 
own suicide, she stays true to her assertion of private over public demands but with an enhanced view of how her death will play out on the world's stage, ${ }^{11}$ a role that, as Shakespeare dramatizes it, guarantees perpetuity to her fame. The difference between her and Octavius's views of private demands is that Octavius always makes primary his accommodation to those sociopolitical needs that are self-promoting. For both Cleopatra and Octavius, egotism is a strong motivating impulse; it shows itself as an ineluctable desire to exert power and control and to be noted for each instance of success, whether in a private or public arena. Interestingly, in spite of her flaws, we admire Cleopatra in part because of her strong bonding instinct, whereas, because he lacks humanity, we tend to be repelled by Octavius. He may have a personal side, as his questionable treatment of his sister and his marriage to Livia suggest, but Shakespeare does not make clear whether the triumvir's feelings for his sister are the result of genuine love, the need for political "cement" (3.2.29) and show, or a confusion of the two; moreover, he never dramatizes the relationship between Octavius and Livia. Early in the play, Charmian indicates that Octavius is not married: "Find me to marry me with Octavius Caesar, and companion me with my mistress" (1.2.27-29); but, later (in 5.2.167), Cleopatra mentions his wife Livia, the first and only indication in the play that Octavius has wed. Instead of depicting Octavius as someone with a capacity for forming connections with other human beings, Shakespeare chooses to concentrate on his robotic behavior, making us unsympathetic to him, even if we are readily able to acknowledge that he possesses the formula for worldly success. ${ }^{12}$

Like Antony, Enobarbus becomes trapped in a conflict of personal and professional demands, a situation that intensifies the difficulties of measuring up. After deciding to affirm his public success as a warrior in service to the Roman Empire by joining Octavius Caesar's forces, he dies heartbroken and shamefully as someone who has betrayed a friend, thereby affirming the superiority of personal loyalty. The difference between Antony's and Enobarbus's dilemmas is that the latter's is wholly of his own making - namely, his unwise decision to desert Antony and fight for Octavius Caesar, but, as the colloquial saying tells us, he was caught between a rock and a hard place. In combination with Antony and Cleopatra's suicides, Shakespeare's dramatization of Enobarbus's conflict and his portrayal of the warrior's death from a broken heart suggest an authorial sympathy with personal bonding over sociopolitical needs, even though the play makes patently clear the absoluteness of the power of the latter. In general, Shakespeare's public-private dichotomy prevents us 
from whitewashing the fame of the play's historical figures and, in fact, impedes the impulse to blindly idealize anyone's fame.

To add to the complexity of the public-private conflict, in the final two acts of the drama, the spotlight shifts from an almost exclusive focus on the characters' mortal existence to one that encompasses their deaths and subsequent fictionalized immortality. In thus widening the lens, the play explores what it takes to become a legendary figure-or, to put it in more contemporary terms, a transhistorical celebrity. As I mentioned in the preceding chapter, Shakespeare well knew when he wrote the play that, however much he could count on his audiences regarding Antony and Cleopatra, not to mention the actors playing them, as celebrities (in the twenty-first century's sense), he was chiefly interested in them as historical figures who had retained their famed status for almost seventeen centuries. Thus, the play both reflects and refashions the couple's iconic status while, at the same time, dramatizing a striking perspective on the process of becoming permanently renowned. The continuing existence of Antony and Cleopatra as a scrutinized text and as a staged drama in the twenty-first century indicates that the play's concern with the imaginative construction of celebrities who sustain their popularity across centuries presents a timeless subject of significant interest. As such, the subject also piques a metadramatic curiosity about the transformation of Shakespeare himself into a transhistorical celebrity, the subject of Chapter 7.

The minor characters in the play are as concerned with standards of measure as are the main characters. The difference is that, usually, they do not apply the standards to themselves but only to the central characters, thereby acknowledging and promoting their fame. ${ }^{13}$ In watching the world leaders strive for satisfaction in their public and private roles, we cannot help but notice that invoking implicit and explicit standards of measure permeates their speeches, and we are alerted to the importance of their preoccupation by the underling Philo's focus in the opening lines of the play: "Nay but this dotage of our general's / O'erflows the measure" (1.1.1-2). Both Antony and Cleopatra constantly gauge their own actions as well as those of each other; and Enobarbus, Octavius, and Pompey actively participate in self-measurement in their desire to account for the success or failure of their actions. Sometimes, they do so with a patent awareness of their status as celebrated persons and sometimes they do not; but, ultimately, unlike Octavia, these five characters are conscious of their position in history, what Enobarbus matter-of-factly terms "a place i'th'story" (3.13.46). 
Shakespeare well understands that an engagement with standards of measurement is natural to the human condition-in fact, a behavioral imperative. Consequently, it is crucial to increasing an individual's knowledge of the private and sociopolitical behavior of people, including the knowledge of one's own conduct in both contexts. In effect, measuring up becomes a necessary activity for all people as they set about to locate, establish, develop, or affirm their identity, at times as a means of countering feelings of low self-esteem. In Antony and Cleopatra fixing one's identity is of major concern to the characters and, yet, always made virtually impossible because, to adopt Antony's metaphor, "even with a thought / The rack dislimns" (4.14.9-10). People and events in the world of the play, as well as what they signify, are constantly in flux, always evanescing, never able to "hold ... [their] visible shape" (4.14.14). Not incidentally, this condition also provides a wealth of possibilities for the dramatist.

Given the stature of the persons characterized and the importance of the historical setting, viewers and readers accept the inability of the characters to measure conduct and events by ordinary standards. Enobarbus tells us that Cleopatra "makes hungry / Where most she satisfies":

Age cannot wither her, nor custom stale Her infinite variety. Other women cloy The appetites they feed, but she makes hungry Where most she satisfies. For vilest things Become themselves in her, that the holy priests Bless her when she is riggish.

$(2.2 .245-50)$

Cleopatra claims that in Antony's “livery / Walked crowns and crownets":

His legs bestrid the ocean; his reared arm Crested the world; his voice was propertied As all the tunèd spheres, and that to friends; But when he meant to quail and shake the orb, He was as rattling thunder. For his bounty, There was no winter in' $t$; an autumn 'twas That grew the more by reaping. His delights Were dolphin-like; they showed his back above The element they lie in. In his livery Walked crowns and crownets; realms and islands were As plates dropped from his pocket.

$(5.2 .81-91)$ 
Although Enobarbus's praise of Cleopatra is replete with hyperbole, are we nevertheless able to conclude that paradox is the symbol of an audience's standard of measure for Cleopatra and hyperbole for Antony? The standards applied to Cleopatra and Antony here are suggestive rather than definitive; as such, they tease our imaginations without speaking to our rational understanding. The reality of measurement in the play requires "new heaven, new earth" (1.1.17), even if it is more in words than action. As audience members, we are asked to "ascend / The brightest heaven of invention" (Henry $V$, Prologue 1-2) as we let Shakespeare on our "imaginary forces work" (Henry $V$, Prologue 18).

In both Enobarbus's and Cleopatra's declarations, Shakespeare portrays what he has long believed to be the truth of the imagination-namely, that it is realistic to think that imagined fantasies, whether about achieving fame, can prove true. ${ }^{14}$ Forever active in human beings, the imagination creates realities that are sometimes brief and sometimes long lasting. As suggested above, the fantasies of the Antony in the play about the longevity of his former heroic reputation may at first seem naively optimistic and far-fetched. He tells Thidias to report back to Caesar: "Look thou say / He makes me angry with him; for he seems / Proud and disdainful, harping on what I am, / Not what he knew I was" (3.13.144-47) and, as he is dying, tells Cleopatra to "please" her "thoughts / In feeding them with those my former fortunes, / Wherein I lived the greatest prince o'th'world / The noblest" (4.15.54-57). Cleopatra sustains and enhances the legend of Antony's heroic superiority in speaking to Dolabella in the passage just cited. Outside the play, in the historical record, and up through the twenty-first century, the belief in and celebration of Antony's heroics also hold true. Within the play and outside, the imagination creates a reality that gives it credibility as a powerful natural force in human behavior. Myth making is as essential to life as it is to drama and therein lies the potent truth of the imagination.

There is a parallel to be drawn between the inability of the characters in the world of the play to measure Antony and Cleopatra by ordinary standards and our inability as a reading or viewing audience to measure by ordinary standards the aesthetic achievements of the playwright. If we try to determine how the play measures up to classical or Renaissance dramaturgical standards of decorum, we are prevented from doing so at every turn because we are unable to apply conventional standards of measure to the play's characterizations, language, structure, and genre. In doing so, 
Shakespeare achieves two related aims at once: he unsettles our attempts to maintain a stable perspective in responding to the play aesthetically, and he subverts our traditional notions of artistic standards of measure. What do we make of the ambivalences and ambiguities that engulf these largerthan-life figures? Why is there such disparity between the words used to delineate the superior achievements of the characters and their dramatized actions? How do we account for a sprawling structure that sometimes dawdles and sometimes moves lickety split? There are too many scenes and, yet, Shakespeare has included seemingly extraneous scenes that do not advance the plot-for example, those with Pompey at the beginning of Act 2 and Ventidius at the beginning of Act 3; is this tendency toward expansiveness meant to suggest the epic reaches of the play? Why do the seemingly extraneous scenes not help to clarify instances of ambivalence and ambiguity? Is the story of Antony and Cleopatra ultimately a tragedy? At the same time that the playwright dislodges us from conventional responses, he challenges us to invent new standards, continually exercising our imagination. The play immerses us in an artistic event that, even when we find ourselves ill equipped to measure it aesthetically, nevertheless provides exhilaration "past the size of dreaming" (5.2.96). Like the underlings in the play, we most often experience feelings of awe or wonder toward these celebrated figures-in our case, largely because of the striking, uniquely stylized language but also because of Shakespeare's dramatizations of unexpected situations and actions of famed persons, including those situations and actions of which we are told but do not see take place. We clearly view the flaws of Antony and Cleopatra and, yet, we assent finally to their greatness without fully understanding what Shakespeare has done to make us believe in it or how to measure his accomplishment in instilling it.

But, specifically, what standards does the play dramatize and of what does the process of meeting them consist? How does Shakespeare choose to deal with the inevitable impediments to the characters' achieving gratification in their various roles during their lives, and after, as legends? What final position does the play take toward the characters' struggles to measure up? What does Antony and Cleopatra reveal metadramatically about Shakespeare's own sense of measuring up and the creation and longevity of his fame? We can begin to answer these questions by examining the first act of the play. 
As I briefly touched on in the last chapter, the play opens with moralistic criticism familiar to its initial seventeenth-century audiences: Antony's immoderate behavior as a lover is widely condemned because of the degree to which he no longer measures up as either a Roman warrior leader or, to a less clear extent, a triumvir. Criticized with equal severity, Cleopatra is vilified as a whore, a woman who has willfully seduced Antony and led him away from his duties as a military commander and a major ruling figure of the Roman Empire. For an understanding of the prevalent early modern view of the lovers, we have only to recall Edmund Spenser's placement of both Antony and Cleopatra in Lucifera's dungeon at the House of Pride where with their fellow prisoners they are condemned for "mortgaging their lives to Covetise, / Through wastfull pride and wanton riotise" (The Faerie Queene I. 5.47.4-5). ${ }^{15}$ Among other well-known Romans in the dungeon is "fiers Antonius" (The Faerie Queene I. 5.49.9), whom Spenser later censures in "The Book of Justice" for allowing himself to be made weak by love. In "The Book of Justice," the poet laments that those heroes who could not be conquered by strong men were defeated and made weak by women:

\footnotetext{
And so did warlike Antony neglect

The worlds whole rule for Cleopatras sight.

Such wondrous power hath wemens faire aspect,

To captive men, and make them all the world reject.

(The Faerie Queene V. 8.2.6-9)
}

In characterizing the women in Lucifera's dungeon, Spenser tells us that "Amongst these mightie men were wemen mixt, / Proud wemen, vaine, forgetful of their yoke" (The Faerie Queene I. 5.50.1-2), including "High minded Cleopatra, that with stroke / Of aspes sting her selfe did stoutly kill" (The Faerie Queene I. 5.50.7-8). Thus, neither of the lovers is exempt from Spenser's stern censure. Spenser adheres with firm disapproval and misogynistic fervor to the prevailing patriarchal view of the standard roles of both men and women. Shakespeare's play not only subverts this view but also the moralizing mode that gives it expression.

Throughout the drama, although both Cleopatra and Charmian find the moralizing mode useful, its expressive manner is most often associated disparagingly with the Romans who are fond of reductionist moralisms. From the outset, however, Philo unwittingly complicates and even confuses this linkage. ${ }^{16}$ Clearly an Antoniophile but displaying built-in Roman biases, he bemoans his leader's involvement with Cleopatra. With 
unabashed ardor, he accuses Antony of "dotage," complaining heatedly that, in his lust, the triumvir "o'erflows the measure" (1.1.2; my italics) and "reneges all temper" (1.1.8). We are thereby alerted to the play's first instance of measuring up and, given the seriousness of the accusation, to its essential importance. Apparently, it is acceptable and even commendable that Antony makes use of the same energetic excess "in the scuffles of great fights" (1.1.7) in which" his captain's heart" "hath burst / The buckles on his breast" (1.1.7-8). As if this slippery double psychological standard were not enough to make us question Philo's judgment, his own manner of expression so o'erflows the measure that we are left to wonder whether the highly inflammatory language in which he couches his censoriousness reflects a sound assessment, for, if we respond to him as a realistic figure, he advocates a control over emotion that he himself cannot exert.

Another, contradictory element occurs as Philo characterizes Antony, for even as he tears his leader down, he builds him up-not only in the description of Antony's powers as a military commander and fighter (1.1.2-10) but also in characterizing him in the same breath as both "the triple pillar of the world" (1.1.12) and a "strumpet's fool" (1.1.13):

Nay, but this dotage of our general's

O'erflows the measure. Those his goodly eyes

That o'er the files and musters of the war

Have glowed like plated Mars, now bend, now turn

The office and devotion of their view

Upon a tawny front. His captains' heart,

Which in the scuffles of great fights hath burst

The buckles on his breast, reneges all temper

And is become the bellows and the fan

To cool a gipsy's lust....

Look where they come.

Take but good note, and you shall see in him

The triple pillar of the world transformed

Into a strumpet's fool. Behold and see.

$(1.1 .1-13)$

In line 12, "triple" seems to mean "third" ("one of three"). The phrase is set in a grandiose style of discourse, especially with the extraneous addition of "of the world," which adds an initial epic enlargement to Antony and the milieu. Immediately following the lofty phrasing of "The triple pillar of the world," Shakespeare further elevates the diction with "transformed." 
Philo could have said something less formal and less suggestive, as, for instance, "you will see that Antony has changed for the worse," etc. That he does not is one of many indications of Shakespeare's desire to contribute to the heroic renown and eminence of his protagonist through an epic-romantic high style. Philo's standard of measure, although applied largely to Antony's heroic military achievements, marks "the triple pillar of the world" as someone whose fame rests solely on the past performance of demigod-like feats in combat. Even before the notion is given frequent dramatic support in the rest of the play, we are able to conclude from Philo's words that, for those who wish to become famous, not only must extraordinary actions be their norm but also that what sustains their fame will be that the actions continue to be characterized—and in a specialized manner befitting their uniqueness.

Thus, the recounting of such actions requires a sophistication in the language that rises to the level of eloquent hyperbole; at the same time, the epic environment of the world in which the characters reside needs to be established through intensified and enhanced language. ${ }^{17}$ One notices in Philo's speech that, whether employed to elevate or debase Antony, the language and syntax contain refinements that seemingly identify the style as grandly over-articulated. As a result, the style itself forces the audience to respond with a detachment that enables them to become aware of the linguistic devices of contrivance: the controlled eloquence (1.1.2-6); the fervent expressive intensity (11. 1-2, 5-9, 11-13, and the emphatic absoluteness of the phrase "reneges all temper" [my italics]); the strongly emotional, connotative element in several of the words (e.g., "dotage"1.1.1, "office and devotion" 1.1.5, "gipsy's lust" 1.1.9, "triple pillar" 1.1.12, "strumpet's fool" 1.1.13); the suggestive ambiguity in word ("goodly" 1.1.2) and phrase ("His captain's heart ... hath burst / The buckles on his breast" 1.2.6-8); the lyrical lilt and parallelism in phrasing ("files and musters" 1.1.3, "now bend, now turn" 1.1.4, "office and devotion," 1.1.5, "bellows and a fan" 1.1.8, "Behold and see" 1.1.13); the striking variety in the choice of details and level of language (from "Mars" 1.1.4 to "scuffles" 1.1.7); the uncommon use of common details (1.1.6-9); and the overall imaginative freshness, all elements that characterize the language throughout the play. ${ }^{18}$ We have yet to hear language raised to the exalted heights of grandiloquence, but Shakespeare is holding this distinction in reserve for his protagonists.

The abstract, generalized diction in the speech and the impersonal description of Antony's eyes and heart couched in an ostensibly mannered 
style create a detachment that prevents us from feeling Philo's enmity toward the present conduct of the hero. Markels maintains that here, as well as throughout the play, "the style keeps subordinating the persons to their actions, which are then universalized by the abstractness of the diction." ${ }^{19} \mathrm{He}$ feels that in Philo's speech "The effect of the diction is to purify the conduct described of the sullied flesh that is its medium; the effect of the syntax is to remove and cleanse Antony from the moral taint of that conduct." ${ }^{20}$ Although Markels's first statement contains evident truth, I am not convinced of the moral focus, the ethical purifying and cleansing process described in the second pair of sentences. Instead, I believe that Shakespeare's focus seems to be more aesthetic than moral and that, whether the actions of the characters are admired or denigrated, the style deliberately creates a larger-than-life, epic magnification of these already renowned figures from history. Such a style would be inappropriate in dramatizing figures with lesser repute unless it were used to parody them. Shakespeare must have known that he had to do something that had not been done before in portraying historical figures so well known for centuries, apart from simply bringing them onto a stage. He relied on his most extraordinary talent - an inspired use of language. The immortalizing power of their fame required it.

Like other characters in the play who are presented as common men and women, Philo uses expressive refinements intended to sound incongruous and therefore all the more impressive coming from a person of his social status. ${ }^{21}$ Shakespeare draws attention by this means to the manner as well as to the substance of the speech; in this way, Philo foreshadows the higher placed underling Enobarbus in his well-known burst of eloquence describing Cleopatra to Agrippa and Maecenas (2.2.200-250). In setting a tone tantamount to the sophisticated discourse that produces it, Philo's vivid manner of speaking clearly invites as much admiration as wonder. Consequently, in discussing Shakespeare's newly minted play with language, one way of viewing the style and tone of Philo's words and those of the other subordinate commentators is to understand Shakespeare's incorporation of elevated language as a necessary ingredient in promoting the fame of the characters, their worldwide milieu, and the historic events that envelope them. The use by so many minor characters of this exalted style suggests a harmonious unanimity in sustaining Antony and Cleopatra's fame through style alone, apart from content. Whatever else Philo's speech accomplishes through its content, including leveling harsh criticism on Antony and Cleopatra's conduct, its style only enhances the 
fame of the two characters it discusses. In opening the play with a speech of this caliber from an ordinary person, a none-too-reliable choral figure never to be seen again, Shakespeare immediately sets a stylistic norm that cannot help but uphold an elevated level for the rest of the drama as it portrays the acclaim of its famous historical figures and their epic world.

As this first scene continues, Antony and Cleopatra enter with a "Flourish," a trumpet fanfare used to signify the approach of one or more persons of distinction. The couple is followed by a lavish and exotic parade of courtiers, including eunuchs fanning Cleopatra. ${ }^{22}$ Immediately, the luxurious spectacle initiates a series of incidents intended to undercut Philo's characterization of the protagonists' romance as low-grade and debilitating. The narrowness of Philo's perspective becomes more luminous by the moment. In addition to orchestrating the spectacle of their entrance, Antony and Cleopatra are conscious of themselves as celebrated figures speaking publicly in sophisticated banter. They talk about measuring up as lovers but, clearly, not simply as sexual lovers. They center their focus on the nature of an exceptional love and by implication on them as lovers capable of rising to the heights of such a love-again, a concern with measuring up. Cleopatra begins the brief, witty exchange by challenging Antony to declare how deeply he loves her: "If it be love indeed, tell me how much" (1.1.14). Antony parries, adroitly asserting in an authoritative, generalized, familiar maxim that, if love can be measured, it lacks depth: "There's beggary in the love that can be reckoned" (1.1.15). Sensing, as she later expresses to Charmian (1.3.6-12), that to captivate Antony requires crossing him rather than acquiescing to him, Cleopatra then imperiously announces that she will set limits to his love: "I'll set a bourn how far to be beloved" (1.1.16). Antony is clearly delighted by the cleverness of her mock stentorian concern with control, restrictions, and by the comic exaggeration that turns her remark into nonsense, for he responds joyfully but seriously with a hyperbolic declaration of his own, evidently affirming a godlike norm of measurement in the world of these two lovers: "Then must thou needs find out new heaven, new earth" (1.1.17). In capping the exchange, Antony's exalted, biblically allusive language pays Cleopatra an exceptional compliment. It also reinforces the strain of cosmological imagery associated with the lovers, begun, as we have just seen, in Philo's speech with the extraneous, expansive phrase "of the world" (1.1.12); some version of this phrase is used again and again throughout the play for the purpose of creating an epic milieu of exalted importance. ${ }^{23}$ Expressed with stylized wit and grandeur, the exchange focuses on measuring up to a 
love deeper than a sexual union and, as a result, indicates in both content and style why the lovers might well be celebrated for their union. In making their statements so emphatically and with such absoluteness, Antony and Cleopatra effectively use the Roman moralizing mode heard in Philo's speech against itself. Shakespeare thereby implies through style as well as content the inadequacy of Philo's assessment of the liaison and the limitations of the general Roman tendency to reduce love to lust. Moreover, whether we consider Philo a realistic, representational, or functional figure (or some combination thereof), the contradiction between what he was saying and the way in which he was saying it now further underlines the confusion and narrowness of attempting to apply a too simple standard of measurement to the lovers. ${ }^{24}$

The scene moves abruptly forward with Cleopatra's grating, mockRoman belittlement of Antony for not measuring up to the standards set by his wife, Fulvia, and his fellow triumvir, Octavius Caesar (1.1.21-34). Her disparaging remarks unleash Antony's intensely emotional declaration that his and Cleopatra's love takes precedence over his Roman responsibilities, and, for the moment, it does:

Let Rome in Tiber melt and the wide arch Of the ranged empire fall! Here is my space. Kingdoms are clay; our dungy earth alike Feeds beast as man. The nobleness of life Is to do thus, when such a mutual pair And such a twain can do' $t$ - in which I bind, On pain of punishment, the world to weet We stand up peerless.

$(1.1 .35-42)$

Here, Antony measures the potency of their love using three distinct standards: First, by rejecting the narrow, Roman, moralistic standard of measurement, he places their bond in the elevated context of their mortality-a less provincial, more universal, and even more seriously philosophical perspective than the Romans ever articulate. Second, Antony declares emphatically that his and Cleopatra's capacity for love is unique, "peerless" (1.1.42), the sublime result of "such a mutual pair" (1.1.39), two larger-than-life, celebrated figures; at the same time, he dignifies their liaison by designating the forging of their union as "the nobleness of life" (1.1.38), a sentiment that, in its form as a moral generalization and in its absoluteness, bestows stature authoritatively on the relationship even as 
it establishes a distinct standard of measure. Third, speaking as a military commander accustomed to issuing instructions to his troops, he makes his proclamation public and commands "the world" (1.1.41) to know that the two lovers stand up "peerless"; by making public his declaration and by reminding his audience that the two participants are unique, Antony enshrines their love-an Egyptian value cleverly couched in a Roman locution. Those who would regard the speech as mere bluster, the vexed consequence of Antony's frustration at the contention between his desires and his guilt, still have to account for the grandiose imperative manner of expression, the wisdom of Antony's philosophical understanding of the context of mortality, his recognition that he and Cleopatra are "peerless" in their union, and his sense that "the world" is interested in them as two paragons deeply in love. In this speech, however we understand its psychology, we see that Antony has a clear awareness of his and Cleopatra's iconic preeminence.

In response, Cleopatra sustains her cauterizing stance, hoping, somewhat foolishly we soon learn, to keep Antony on the defensive so that he will continue to concentrate his attention on her and not on his Roman responsibilities. Her effectiveness takes a form we might not have predicted. Antony unexpectedly turns his response into a glowing, hyperbolic tribute to her energy and emotional intensity, two of the same standards of measurement he instinctively sets for himself in his love for her:

Fie, wrangling queen,

Whom everything becomes, to chide, to laugh

To weep, whose every passion fully strives

To make itself, in thee, fair and admired!

$(1.1 .50-53)$

The key words here are "everything," "every," and "fully strives," words conveying in their exaggerated absoluteness a standard of perfection that, although intensely biased, is not modified elsewhere in the play. The passage reveals Antony's loving admiration of the genuineness of Cleopatra's extraordinary élan vital and his wonder at the attractiveness of its display. But it also alerts us to his own brand of élan vital, already characterized by Philo (1.1.6-8). Such full-fledged, forceful energy is a prerequisite to measuring up in this play, whether as lover or heroic warrior, because the person who "fully strives" can completely plumb the rich density and excitement of his or her actions. And, of course, people then as now commonly 
believed that this ability and the feats that result can constitute a major part of what makes a person of fame famous or a celebrity a celebrity.

At the conclusion of the scene, Demetrius seems crestfallen to see that Antony has so little regard for Caesar and his Roman obligations, the illustrious military hero and triumvir having fallen prey uncontrollably to his passions. He differs in his focus from Philo because he thinks of Antony more as a triumvir than as a military figure, but his negative evaluation is the same. Philo, a bit embarrassed, tries to mollify his fellow Roman's reaction: "Sir, sometimes when he is not Antony / He comes too short of that great property / Which still should go with Antony" (1.1.59-61). The Antony he speaks of is the celebrated heroic figure that the world acknowledges Antony has become. Philo assumes that there is an essential aspect of Antony that has made him great and enabled him to become a hero. But, from his limited perspective, he sees this essence as operating in only one context. We are about to learn, however, that Antony is a man divided, unhappily in conflict with his public Roman and personal Egyptian ties and that, try as he might, his essence cannot satisfy the demands of both contexts simultaneously, although, paradoxically, it can operate magnificently in each. As we have just seen, the application of the Roman standard of measurement by Philo and Demetrius is shortsighted. Shakespeare has already invoked a more complex psychological perception, one that makes Roman moralizing seem merely theoretical, an abstract concept, and too simple-in concrete human terms, psychologically inaccurate and therefore not applicable. Thus, in dramatizing this situation, Shakespeare makes us aware of the virtues of a psychological over a moral perspective when scrutinizing people-as we shall see, a notion the play continually supports.

In addition, we are led to the truism that what people see depends upon the perspective they adopt. ${ }^{25}$ The Romans view their value system differently from the Egyptians, and the same competing perspectives are true of the Egyptian value system. For example, the Romans already believe they know what makes Antony extraordinary and, as far as it pertains to his heroic feats, they are accurate. But their view does not encompass enough, for it does not take into account his magnanimity, his "bounty" (4.6.22, 4.6.33, and 5.2.85), ${ }^{26}$ and his ability to inspire as a lover as well as a military leader. Ironically, in making Antony a chief subject of discussion, the Romans are also responsible, in part, for intensifying Cleopatra's fame as a celebrated royal figure. The Egyptians accurately portray the limitations of the Romans but do not acknowledge the 
absolute necessity for sociopolitical considerations. As previously mentioned, we almost never see Cleopatra in her political role as Queen of Egypt, tending to her administrative duties as ruler. ${ }^{27}$ The two systems at first seem readily distinguishable: whereas the Egyptians usually assert the pleasures of one's private life over the sociopolitical needs of the state, the Romans show concern largely for public interests, including power and authority. Unsettling this neat dichotomy, however, are those representatives on each side who alter their views: the Egyptian Cleopatra ends up dying, believing that it is "after the high Roman fashion" (4.15.92); the Roman Enobarbus dies affirming personal loyalty over sociopolitical opportunities for success; and the Egyptian Charmian imitates her mistress in committing suicide "after the high Roman fashion." Antony swings back and forth, first adopting one value system and then the other, until his death when he tries to combine both. Thinking Cleopatra has taken her life, Antony's anger toward her immediately dissipates, and he exclaims:

I will o'ertake thee, Cleopatra, and

Weep for my pardon. So it must be, for now

All length is torture; since the torch is out,

Lie down and stray no farther. Now all labour

Mars what it does; yea, very force entangles

Itself with strength. Seal then, and all is done.

Eros!-I come, my queen.-Eros!-Stay for me.

Where souls do couch on flowers, we'll hand in hand,

And with our sprightly port make the ghosts gaze.

Dido and her Aeneas shall want troops,

And all the haunt be ours.

(4.14.44-54)

After he falls on his sword and is conveyed to Cleopatra's monument, he tells her:

The miserable change now at my end

Lament nor sorrow at, but please your thoughts

In feeding them with those my former fortunes,

Wherein I lived the greatest prince o'th'world,

The noblest; and do now not basely die,

Not cowardly put off my helmet to

My countryman-a Roman by a Roman

Valiantly vanquished.

(4.15.53-60) 
Antony's admission that "very force entangles / Itself with strength" (4.14.48-49) realistically encapsulates the entanglement that results from his trying to exist in a world of irresolvable, contrasting perspectives. Thus, the dichotomy ultimately becomes for an audience as difficult to assess and fix as Antony's dissolving clouds (4.14.1-22), and, as the standards of measure shift, they become more individual and deeply psychological than abstractly conceptual and general in their application.

In his discussion of the first scene of the play, John Danby contends that we are unable to come to a judgment about the Egyptian and Roman stances because of the deliquescence that is at the heart of the play. ${ }^{28}$ There is truth in his argument. We are unable to fix our impressions of Philo, whose contradictoriness puzzles us, and Demetrius, whose word "liar" in the phrase "the common liar" jolts us with the suddenness of its unexplained, denigrative realism and contradictoriness. ${ }^{29}$ Upon their entrance, Cleopatra and especially Antony appear to qualify Philo's accusations, but Demetrius does not think so. Because the lovers first appear in public before the entire court, we may wonder to what extent they are aware of performing before their court audience and how such awareness might color their remarks. As for the audience of the play, what ultimately adds to their consternation and ambiguity is the speed with which events take place, not only in this scene but throughout the play. Shakespeare makes sure that we are unable to get our bearings and maintain them for any length of time. Deliquescence keeps forcing them to dissipate. But, at the same time, the elusiveness fuels our interest.

In the first part of the second scene of the play, the idea of measuring up is treated with humor. Charmian has comic illusions of grandeur: "Let me be married to three kings in a forenoon and widow them all. Let me have a child at fifty, to whom Herod of Jewry may do homage. Find me to marry me with Octavius Caesar, and companion me with my mistress" (1.2.25-29). A bit later the comic standard of measure turns bawdy:

Iras: Am I not an inch of fortune better than she [i.e., Charmian]?

Charmian: Well, if you were but an inch of fortune better than I, where would you choose it?"

Iras: Not in my husband's nose. $(1.2 .53-56)$

In the first passage, Charmian's spirited fantasies show her desiring to imitate Cleopatra in her fame and to become her "companion" rather than her attendant. It is not until her death, however, that Charmian actually 
measures up as a companion when in a fervent show of bonded loyalty, she imitates Cleopatra's "noble act" (5.2.279) of suicide. In the second scene, Shakespeare comically portrays the significant difference between the aspirations and goals of the two women, but obviously to the Queen's credit as a regal, royal figure with loftier, more complicated behavior and more concentrated aims; moreover, in contrast to Charmian's sexual fantasies, the playwright keeps before us the notion that Cleopatra's allure is nothing short of astonishing. Iras's bawdiness in line 56 stands in opposition to the deep love that Antony and Cleopatra have just spoken about, their non-physical standard of measure, and to the urbane, clever way in which they speak about it. Again, this scene manages to pay tribute to the lovers even if only indirectly; even so, a chief source of its continuity with the preceding scene is to be found in its focus on measuring up.

In the next segment of the scene, Cleopatra enters and abruptly exits, deciding not to confront Antony, because earlier "A Roman thought hath struck him" (1.2.78), a frame of mind that, presumably, she assumes still has full possession of him; her suspicion is confirmed when she glimpses the triumvir's solemn conversation with a messenger, who tells Antony of the military threats of Labienus and of the death of Antony's wife Fulvia; by the end of the scene we realize that Antony also comprehends the impending danger of Pompey to the Roman Empire. Enobarbus enters in a jovial mood, but Antony is so ridden with guilt from not tending to his military and political responsibilities that Enobarbus's "light answers" (1.2.169) do not amuse him. Enobarbus's ribald irony and sarcasm apart, the discussion centers enough on Cleopatra's role-playing abilities to suggest once again that she is exceptional (1.2.136-50). Enobarbus's remarks are one more instance of the paradox of undermining Cleopatra while, even in mocking her, he enhances her acclaim. Stricken with increasingly intense guilt at not measuring up to his Roman responsibilities, Antony can only murmur, "She is cunning past man's thought" (1.2.141) and "Would I had never seen her!" (1.2.147). Shakespeare draws the scene to a close with Antony's order to Enobarbus to prepare for their departure. I am not sure what we are to make of the final phrase of Antony's command to Enobarbus: I shall break / The cause of our expedience to the queen / And get her leave to part" (1.2.170-72; my italics). If we consider that Cleopatra is a tributary queen and Antony the triumivir in charge of Egypt, then the phrase is surprising and puzzling. Is asking for permission a part of standard protocol or does it show how much control Cleopatra has over Antony, confirming that he is in fact lost "in dotage" (1.2.13)? 
Or is there a textual corruption? ${ }^{30}$ Again, however we interpret this statement, it is clear that Shakespeare wants to keep the focus on Cleopatra, suggesting that, for good or for ill, she is a figure beyond any commonplace standard of measure. And, of course, in Antony's exclusive reliance on a Roman standard of measure, the scene foregrounds the conflicts and complexities of measuring up.

The third scene reveals two key aspects of Cleopatra's fame as a mesmerizing, amorous queen. Together, they indicate how she participates in the process of measuring up. First, she indicates the genuineness and depth of her devotion to Antony as she "fully strives" to strengthen the bond between them-especially, when she admits with blunt honesty and pointed irony, "'Tis sweating labour / To bear such idleness so near the heart / As Cleopatra this" (1.3.94-96). ${ }^{31}$ In making this statement, she emphatically refutes Antony's attribution of "idleness" - that is, the foolishness she presumably employs as she toys with him. The metaphor of the labor pains of childbirth jars us with its sudden, realistic frame of reference, explosive candor, and heartfelt accuracy, and, in its truer, contradictory reading of "idleness," reveals what lies behind her antics as well as the genuine effort they involve. As the play demonstrates, she and Antony embrace such intense striving as a necessary means to achieve the highest level of satisfaction in love. For Cleopatra, achieving that level translates into role-playing, spurred by her imagination but triggered always by her profound emotional investment.

The second aspect emerges during the exchange with Charmian at the beginning of the scene. Charmian moralizes, in itself not a mode to which her mistress readily responds, even though she makes clever use of it herself; Charmian instructs Cleopatra that the way to create a loving response in Antony is to "cross him in nothing" (1.3.9). Cleopatra's response is blunt and firm: "Thou teachest like a fool: the way to lose him" (1.3.10). She has determined that the best way to keep Antony enthralled is to be defiant and unpredictable. Enobarbus later confirms the wisdom of her stratagem when he praises her "infinite variety" (2.2.246), and Antony again corroborates it when he leaves the all-too-obliging Octavia to return to Cleopatra. Throughout the present scene, the Queen gives a brilliant performance in which she uses Antony's Roman sense of moral standards against him-e.g., she accuses him of hypocrisy when she tells him that it was "Riotous madness, / To be entangled with those mouthmade vows, / Which break themselves in swearing!" (1.3.29-31). Even so, Cleopatra is unable to loosen the ties of guilt that overwhelm the triumvir 
and, thus, the two clashing value systems end in the lovers' separation. But not before Shakespeare has offered his version of those vital characteristics that make the Queen's feats as a lover exceptional and that immediately add to her reputation and fame.

Cleopatra is wholly self-serving in this scene but her behavior is certainly understandable as a plausible human reaction from a woman seriously in love. What is perhaps less understandable is the unrealistic narrowness of her focus. The unattractiveness of her single-mindedness is countered by her remarkably imaginative, energetic efforts as she "fully strives" to keep Antony in Egypt. Cleopatra has decided on her course of action with Antony and pursues it with such formidable passion, imagination, and intelligence that we cannot help being awed by her manner. Antony measures up to what he sees as his Roman responsibilities, forgetting in the flood of guilt that he cannot do so without incurring permanent unhappiness at having to leave Cleopatra. The Soothsayer later makes predictions that bring the triumvir's true feelings to the surface (2.3.10-40). The present, leave-taking scene, unmitigated in its display of passions, could have been composed as domestic dramedy and been seen as an adumbration of Who's Afraid of Virginia Woolf. But some key phrases and Antony's eloquence show Shakespeare investing it with a stature that makes us know that these are not Edward Albee's Martha and George but distinctly larger-than-life figures: "the greatest soldier of the world" (1.3.38);32 Cleopatra's references to herself as "Egypt" (1.3.41, 78); "this Herculean Roman" (1.3.84); the eloquence of Antony in outlining for Cleopatra what draws him to Rome (1.3.42-56); and his ultimately misguided attempt to be honest and yet compliment her ("But that your royalty / Holds idleness your subject, I should take you / For idleness itself" 1.2.92-94). Thus, while the subject of measuring up promotes the central conflict of the play between public and private claims and enables us to understand the protagonists' failings, the manner of portraying it redounds to the fame of Antony and Cleopatra. The fact of the matter is that the language measures up even when the characters do not.

Beginning the grand shifts between the play's two principal locales, the fourth scene abruptly takes us from Egypt to Rome and to a discussion between Antony's two fellow triumvirs. The focus on measuring up and on background information that explains how Antony's fame as a hero arose out of godlike feats immediately links this scene with the preceding ones. Always alert to events that can have a bearing on the Roman Empire, Octavius has just read a letter detailing Antony's activities in Egypt; he 
reacts with a moralizing intensity that reminds us of Philo's, especially in the final two overstated lines of the following passage ("all ... / all ..."). Lepidus has just cautioned Octavius-in effect, telling him that he is overreacting; a ruffled Octavius retorts with finger-wagging moralisms:

You may see, Lepidus, and henceforth know,
It is not Caesar's natural vice to hate
Our great competitor. From Alexandria
This is the news: he fishes, drinks, and wastes
The lamps of night in revel; is not more manlike
Than Cleopatra, nor the queen of Ptolemy
More womanly than he; hardly gave audience, or
Vouchsafed to think he had partners. You shall find there
A man who is the abstract of all faults
That all men follow.

$(1.4 .1-10)$

Octavius begins his sermonizing with what we quickly come to understand is his customary self-focus, in this case an egotistical defense of what he asserts is a rational reaction. But in his initial instruction to Lepidus, we also sense an overbearing and patronizing attitude. Clearly devoid of any knowledge of the value and nature of pleasure, he criticizes Antony for wasting his time in trivial pursuits among the lowly, then continues with criticism based on prescribed gender roles before he concludes with a thrust at Antony for dismissing his "partners." By the end of the play, we realize that part of the greatness of Antony and Cleopatra is that, by instinct as well as by the power of their positions, they are above the petty restrictions of prefabricated gender roles, still more a perfunctory adherence to them. We also get an indication from Octavius's criticism and from the protagonists' deep-seated tendency to transcend (patriarchal) dictates just how their greatness enables them to disregard behavioral prescriptions for measuring up and, specifically, allows them to create their own standards of measure. Whereas we admire the lovers for their boldness, we find ourselves disconsolate at their inability to integrate their behavior into the sociopolitical world. However, from the perspective of the play as a whole, acting without reference to set rules helps to define Antony and Cleopatra's independence and greatness, inescapable attributes of their fame and, as it turns out, the playwright's.

As the scene progresses, we see once again that, paradoxically, the language enhances even as it denigrates. We hear Caesar's elevating phrase, 
"Our great competitor," Lepidus' eloquent defense, replete with a cosmological metaphor (1.4.10-15), and an outpouring of varied language and metaphors, jostling us through their freshly imaginative phrasing, as in Octavius's excessively exacting, sarcastic response to Lepidus's attempt to mollify Caesar's censoring of Antony:

Let's grant it is not

Amiss to tumble on the bed of Ptolemy

To give a kingdom for a mirth, to sit

And keep the turn of tippling with a slave,

To reel the streets at noon, and stand the buffet

With knaves that smells of sweat.

$(1.4 .16-21)$

With bitter irony, Caesar criticizes Antony for failing to measure up as a public figure. The passage mixes emotionally connotative and intellectually suggestive language. The frame of reference in the language changes abruptly - for example, from "to tumble on the bed" to the mention of the ruling house of Ptolemy, shifting us forcefully from the self-indulgent triviality of Antony and Cleopatra's presumed sexual proclivities to an allusion to the Queen's significant stature as a royal historical figure. The unexpected juxtapositions of details attempt to awe us.

After condemning Antony for neglecting his duties as a triumvir (1.4.21-25), Octavius becomes almost lyrical, opening the next passage with heavily stressed, alliterative " $v$ " sounds; the following lines sustain the emphatic intensity in continuously making use of strong verbs and emotionally connotative language before turning authoritative in a final, climactic generalizing moralism:

\section{If he filled}

His vacancy with his voluptuousness,

Full surfeits and the dryness of his bones

Call on him for't. But to confound such time

That drums him from his sport and speaks as loud

As his own state and ours, 'tis to be chid

As we rate boys who, being mature in knowledge,

Pawn their experience to their present pleasure

And so rebel to judgement.

$(1.4 .25-33)$

The words so captivate us that we become more caught up by the manner of the speech than what it tells us about the speaker. The two messengers 
that appear next shift the focus from Antony to Pompey and the danger he presents. This state of affairs prompts a wailing plea from Octavius followed by a recollection of Antony in former times of greatness. The triumvir's momentary nostalgia gives us our first detailed, concrete understanding of what makes Antony so eminent and why, from Caesar's perspective, he no longer measures up:

Antony,
Leave thy lascivious wassails. When thou once
Was beaten from Modena, where thou slew'st
Hirtius and Pansa, consuls, at thy heel
Did famine follow, whom thou fought'st against
Though daintily brought up, with patience more
Than savages could suffer. Thou didst drink
The stale of horses and the gilded puddle
Which beasts would cough at. Thy palate then did deign
The roughest berry on the rudest hedge.
Yea, like the stag when snow the pasture sheets,
The barks of trees thou browsed. On the Alps
It is reported thou didst eat strange flesh,
Which some did die to look on. And all this-
It wounds thine honour that I speak it now-
Was borne so like a soldier that thy cheek
So much as lanked not.

Shakespeare found the mythic details of this description in Plutarch whose account reveals that, by the second century when he was writing The Lives of the Noble Grecians and Romans, Compared, Antony's exploits had already become legendary. Octavius invokes "honour" as the generalized standard of measure that Antony no longer satisfies. Specifically, he admires Antony's ability to cope with deprivation (1.4.57-72) - in contrast to those, like Cleopatra and Enobarbus, who admire Antony's "bounty"; the two views only amplify Antony's heroic capabilities. In the mouth of someone else, Octavius's description would qualify as hero worship. For the moment, we lose a realistic sense of the speaker and focus on the description of Antony. Significantly, Octavius describes Antony's heroism as a warrior leader but not as a triumvir. Apparently, for Octavius at this moment, Antony's greatness is limited to deeds performed during his past military service. If Antony were presently performing such heroic feats, one wonders whether Octavius would be so in awe of him. But 
perhaps the question is irrelevant since this is clearly an example of what I described in the first chapter as Octavius operating as a "functional" figure rather than as a "realistic character." He could also be considered a representational figure, emblematic of the Roman perspective. In not being portrayed with consistent psychological realism, Octavius serves the function of delineating some particulars of Antony's strongest claim to fame as a hero.

Octavius's mention of "honour" as the highest standard of measure raises the question of honor as a value in achieving everlasting fame. In his book, The aspiring mind of the Elizabethan younger generation, Anthony Esler documents the origins and nature of honor as Shakespeare would have known them from his real-life context. ${ }^{33}$ According to Esler, Robert Devereux, the Earl of Essex was an excellent example of a person who embodied the notion of honor. "The two most important sources of the forms of Elizabethan aspiration for honor were the new Italian courtesy tradition, and the old chivalric tradition of the High Middle Ages" ( $p$. 105). War and court society were the two places where honor could be sought, and justice and courage were the two virtues of honor most idealized and touted. But, as Esler makes clear, "From the vantage point of several centuries, perhaps the most striking characteristics of the Elizabethan cult of honor are its apparent artificiality and its completely unrealistic attitude" (p. 113). He goes on to show that Shakespeare was well aware of "these foibles of his generation" (p. 113). Other characteristics that Shakespeare also was aware of were idealism and egotism, exemplified in Hotspur, and the drive for the approbation of others, Antony's concern: "The shift in emphasis from public reputation to personal integrity took place largely during the seventeenth century" (p. 120). As we shall see, Antony and Cleopatra also reflects this shift.

Presumably, in mentioning "honour," Octavius is thinking in traditional Roman terms, that honor is ultimately sociopolitical, requiring some service to the wellbeing of the state to achieve validity. ${ }^{34} \mathrm{He}$ seems to be saying that Antony's Spartan endurance as a soldier qualified him for a kind of honor that he is no longer able or willing to achieve. But the kind of honor he points to is more a matter of personal glory than service to the state, the very kind of honor Caesar himself is incapable of. As so often happens in this play, we are made to consider concepts pertaining to behavior in both their private and public contexts. In doing so, we discover that there is more than one kind of honor. We have already witnessed in the first and third scenes of the play the intensity with which Antony and 
Cleopatra work at sustaining their liaison. Antony asks Cleopatra to "give true evidence to his love which stands / An honorable trial" (1.3.74-75). He has been and continues to be willing to subdue himself to "an honorable trial" to prove his love for Cleopatra. The standard is clear. The word "honorable" suggests the respect he has for their love and tells us that their affair is anything but cheap and tawdry. It also shows Antony applying a Roman public value to an Egyptian personal situation, something he does again as he prepares for his suicide: "Since Cleopatra died / I have lived in such dishonour that the gods / Detest my baseness" (4.14.55-57). Here, he condemns himself for lacking "the courage of a woman" (4.14.60) in outliving Cleopatra and for having a "less noble mind / Than she which by her death our Caesar tells / 'I am conqueror of myself'” (4.14.60-62). Even in dying, Antony is dominated by the urge to measure up and to be viewed as measuring up. In this instance, he evokes a high personal standard of honor, one that can be judged only by the gods, thereby making it worthy of enduring fame. ${ }^{35}$

In complaining to Octavia of her brother's attempts to disparage him, Antony has earlier introduced the subject of "honour" (3.4). But there he is referring to his reputation or image as a triumvir and military figure: "If I lose mine honour, / I lose myself; better I were not yours / Than yours so branchless" (3.4.22-24). Antony speaks of Caesar's highhandedness and enmity with an awareness of his own stature as a public figure and the permanent damage that Caesar could inflict on his historical image. In keeping with the play's strong interest in standards of measure, it is most telling that Antony complains that Octavius "most narrow measure lent me" (3.4.8; my italics). Octavius has used the ingrained notion of measuring up cynically, for purely political purposes, as Antony is well aware. In his denunciation of Caesar and his acquiescence to Octavia's desire to be a peacemaker, Antony may also be motivated by his eagerness to find a reason to return to Cleopatra. Whatever the complex of motivations, his concern with being perceived as honorable permanently seems genuine, emanating from a conventional, sociopolitical Roman ideal of honor that can extend into the afterlife.

Even so, the play is adept at characterizing the confused and illusory notions of honor as a public standard of measure-just as it is in portraying Antony's sense of alienation in both Egypt and Rome. When Antony returns from Egypt to meet with his fellow triumvirs and Octavius accuses him of breaking the terms of his oath to him, Lepidus, fearful of the intensity of the confrontation, urges Caesar to soften his attack (2.2.87-90). 
But Antony coolly reprimands Lepidus: "let him speak. / The honour is sacred which he talks on now, / Supposing that I lacked it" (2.2.91-93). If Antony is posturing here in speaking of his sense of honor, he is cannily employing a manipulative device that Caesar is not able to overcome. Throughout this meeting, Antony deflects Octavius's accusations by invoking pardonable human situations (i.e., an unruly wife, a hangover) beyond the latter's ability to chastise without seeming petty. He thereby appears to sidestep Octavius' attempt to impugn his honor, whatever definition we give it.

The question this exchange raises is just how clever and politically manipulative Antony is being. After all, he is the one who has introduced honor as a standard of the measure of greatness. Is he building himself up in order to remind Octavius of his (Antony's) longstanding superior stature? Or does he actually consider honor "sacred?" Is professional honor a political tool or a genuine belief, an illusion or reality? Or is it a confused mixture of either dichotomy or both? The same question about illusion and reality might be asked when Pompey rejects Menas's plan to kill the triumvirs and become "lord of the whole world" (2.7.58). He tells Menas:

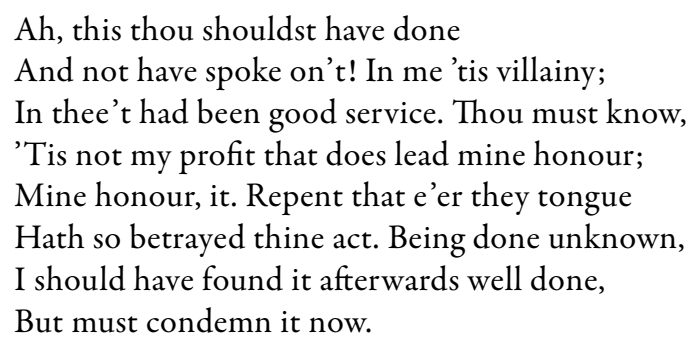

$(2.7 .69-76)$

Pompey's response, couched in terms of Menas's failure to measure up, only deepens our skepticism about honor as a credible public professional value. In the next scene, Ventidius, essentially a choral character, clarifies the contrast between the image and the reality of an honorable reputation when he declares that "Caesar and Antony have ever won / More in their officer than person" (3.1.16-17). The notion of honor is again undermined in an exchange with Thidias, Octavius' deceptive messenger, when he says to the Queen, "The scars upon your honour therefore he [Octavius] / Does pity" (3.13.59-60), and Cleopatra responds with equal hypocrisy, "Mine honour was not yielded, / But conquered merely" (3.13.62-63). 
Like Thidias, Cleopatra is capable of using the concept cynically as a wily move in the game of power politics.

As Antony is dying, Cleopatra vows, "Your wife Octavia, with her modest eyes / And still conclusion, shall acquire no honour / Demuring upon me" (4.15.28-30). Like Antony, Cleopatra is at this moment thinking of her future image as a person of renown; specifically, she imagines how degrading and humiliating it would be for a celebrated royal figure to be paraded through Rome in captivity. The "honour" she speaks of is a sociopolitical notion of honor that she imagines, if she were to be humiliated as a prisoner, would be bestowed on her chief Roman female rival. Responding to her own fabricated scenario, Cleopatra firmly rejects such an occurrence. In so doing, she acquires some personal honor for herself.

Linda Charnes concludes from Cleopatra's comment and the scene more fully that "For both Antony and Cleopatra, love-even at this most critical of moments-cannot transcend the particular textual material it operates in." ${ }^{36}$ Another way of interpreting the scene, however, is that Antony and Cleopatra's bond of love underlies their sorrow and at this point need not be spoken of. But, given the play's sustained portrayal of the nature of imperishable fame and the process whereby it is achieved, the fictionalization of Antony's future reputation does need to be set in motion, especially because of his recent military defeats at the hands of Octavius. In a passage already quoted in another context, Antony himself acts as the model for the fictionalizing process that fame requires:

The miserable change now at my end

Lament nor sorrow at, but please your thoughts

In feeding them with those my former fortunes

Wherein I lived the greatest prince o'th'world,

The noblest; and do now not basely die,

Not cowardly put off my helmet to

My countryman-a Roman by a Roman

Valiant vanquished.

$(4.15 .53-60)$

Sensing the imminence of her own demise, Cleopatra follows Antony's lead in actively demonstrating her concern with her future reputation as well as with enhancing his. The couple's focus would be more surprising if, throughout the play, they were not so self-conscious as renowned figures and if Shakespeare, having made clear their individual weaknesses, were not so zealous in his determination to offset those weaknesses by bes- 
towing on them the grandeur and eminence that he felt their legendary fame required. In 1 Henry IV, Hotspur's idealism about public honor (1.3.201-8) is undercut by his emphasis on honor as an opportunity for personal glory and by Falstaff's contradictory pragmatism (5.1.127-140); ultimately, though, it is made credible through Hal's honorable actions in battle (5.4). But in Antony and Cleopatra, no such credible public standard exists. "Good valor" (4.7.16) is a measure of good soldiering, but such soldiering requires faithfulness and a "workman" (4.4.18). Those who shift allegiances and revolt, as Enobarbus comments, have "no honourable trust" (4.6.18). Antony's "bounty overplus" (4.6.22) in sending Enobarbus's treasure after him and Enobarbus's self-recrimination and death suggest that honor, those few times that it has validity, is embedded in the personal integrity of actions, not words, and that it is more apt to occur in a private situation than publicly in a sociopolitical or military one. For all the talk of honor as a virtue in public life, the play more often allows honor to become a true standard of measure in private contexts. ${ }^{37}$

Cleopatra demonstrates this tendency at the climax of the play, for she views her suicide as "my noble act" (5.2.279), the ultimate test of her love for Antony pressed upon her by the invasive political power of Octavius. Although the suicide itself is Roman in concept, Cleopatra's orchestration of it is pure Egyptian. She finds a way to blend the standards of measure of both worlds and yet be true to her deepest self, both as a lover and a queen. Perhaps from Shakespeare's perspective, this is the strongest reason for her perpetual fame and why he gives her the final act of the play. His decision to conclude the play with Cleopatra's death has a clear effect. In undermining the traditional idealized regard for honor as an exclusively public standard, Shakespeare actually reconfigures honor as an independent, personal basis for fame. This shift reflects Esler's assertion that the change is a seventeenth-century phenomenon.

We have seen in our examination of the first act of the play that Shakespeare's sustained focus on standards of measurement and, ultimately, the relation of these standards to the couple's imperishable fame give us a strong sense of just how thoroughly the need to establish standards permeates the playwright's thinking and imagination. The opening exclamatory words of the play ("Nay, but this dotage of our general's / O'erflows the measure") also declare that measuring up will be a major subject in the drama. The number of metaphors of measurement in the play is a further 
indication of how secure a hold the notion has on Shakespeare. The following list covers only explicit references to measurement; it does not take into account such episodes as when Cleopatra evaluates her competition by asking the Messenger about Octavia's physical features (3.3):

1. Octavius uses a metaphor of scales to criticize Antony: "yet must Antony / No way excuse his foils when we do bear / So great weight in his lightness" (1.4.23-25).

2. Using an image of a carpenter's square and rule, tools of measurement, Antony admits to Octavia: "I have not kept my square, but that to come / Shall all be done by th'rule" (2.3.6-7).

3. Antony explains to Octavius that measuring the height of the Nile reveals whether famine or abundance will ensue (2.7.16-22).

4. Antony comforts Cleopatra tenderly, "Fall not a tear, I say; one of them rates / All that is won and lost" (3.11.68-69); "rates" indicates that the form of measurement here is emotional, not physical.

5. Fearful of Antony's death, Cleopatra laments to Charmian, "Our size of sorrow / Proportioned to our cause, must be as great / As that which makes it" (4.15.4-6).

6. To Dolabella, Cleopatra asserts that Antony is "past the size of dreaming" (5.2.96), that no dream could match the image she has of him. Cleopatra's illusion contrasts with Enobarbus's earlier characterization of Antony's delusion in thinking that Octavius would fight him in single combat: "That he [Antony] should dream, / Knowing all measures, the full Caesar will / Answer his emptiness" (3.13.34-36).

Given the naturalness of measuring as an element basic to the human condition, it is no surprise that the play supports the romanticized view that setting standards and meeting them is essential to a life lived to the lees, a goal both Antony and Cleopatra cherish and aspire to, despite the many impediments. Of course, this is not the first time Shakespeare has concerned himself with standards of measure-as his play Measure For Measure patently suggests. There, amid the profusion and confusion of psychological and moral perspectives, the play focuses on the difficulty of establishing a proper balance between mercy and justice; how does one ascertain the measure of each to be meted out in order to achieve such a balance? For all its ambiguity, Antony and Cleopatra marks an advance in dealing with the conflict that Shakespeare conceives between 
psychological and moral perspectives; it is the first time that the psychological perspective has been so forcefully elevated and the moral perspective so devalued. To see how this emphasis adds to the delineation of measuring up and the permanence of fame, not to mention the uniqueness of the play, we move next to an examination of some key scenes in the remainder of the play and finally to the double climax.

\section{NOTES}

${ }^{1}$ In this trait, Cleopatra of course bears ties with Virgil's and Marlowe's portraits of Dido.

${ }^{2}$ Julian Markels, The Pillar of the World: "Antony and Cleopatra" in Shakespeare's Development (Columbus: Ohio State University Press, 1968), p. 163. Markels follows up this statement with quotations from the play that substantiate his observation; see pp. 164-67.

${ }^{3}$ Mark Rose, ed. and intro., Twentieth Century Interpretations of "Antony and Cleopatra": A Collection of Critical Essays (Englewood Cliffs, NJ: Prentice-Hall, 1977), p. 9. Pages 8-9 contain the full discussion.

${ }^{4}$ See MacDonald, "Playing Till Doomsday." On p. 80, footnote 3, MacDonald lists the following well-known studies of ambiguity: Norman Rabkin's Shakespeare and the Problem of Meaning (Chicago: University of Chicago Press, 1981) and his earlier anticipatory theory of "complementarity" in Shakespeare and the Common Understanding (New York: Free Press, 1967); Adelman, The Common Liar; and Maynard Mack's Introduction to the Penguin Antony and Cleopatra (Baltimore, 1960).

${ }^{5}$ MacDonald, "Playing Till Doomsday," p. 80.

${ }^{6}$ MacDonald, "Playing Till Doomsday," p. 89.

${ }^{7}$ MacDonald, "Playing Till Doomsday," p. 84.

${ }^{8}$ MacDonald, "Playing Till Doomsday," p. 84.

${ }^{9}$ MacDonald, "Playing Till Doomsday," p. 84.

${ }^{10}$ See 3.6.12-19 where Octavius reports that Antony extends Cleopatra's ruling powers and for the ceremony she is dressed "In th'habiliments of the goddess Isis" (3.6.17).

${ }^{11}$ Mocking "The luck of Caesar" (5.2.280), the "ass / Unpolicied!" (5.2.301-2).

${ }^{12}$ Not everyone sees Octavius in so dim a light, especially given the historical figure's success as Caesar Augustus after the deaths of Antony and Cleopatra. H. Neville Davies in "Jacobean Antony and Cleopatra," Shakespeare Studies 17 (1985): 123-58, maintains that "no matter how James might have reacted [to Antony and Cleopatra], it is inconceivable that a dramatist late in 1606, the time when Shakespeare is usually supposed to have been writing or planning his play, could have failed to associate Caesar Augustus and the ruler whose propaganda was making 
just that connection" (pp. 124-25). If we abide by what the text presents, Davies's observation seems weakly speculative. For a discussion of those critics who find something to admire in Octavius and those who do not, see Deats, New Critical Essays, pp. 32-34.

${ }^{13}$ I say "usually" because at the end of the play, in imitation of her mistress, Charmian applies the standard of measure Cleopatra has just invoked in committing suicide to kill herself.

${ }^{14}$ See the discussion of imagination in A Midsummer Night's Dream in Chapter 1.

15 All quotations from Edmund Spenser are from The Complete Poetical Works of Spenser, ed. R. E. Neil Dodge (Boston: Houghton Mifflin Company, Riverside Press, 1908).

${ }^{16}$ For additional commentary on this scene, see my article, "The Sexual Attitudes of Marlowe and Shakespeare," University of Hartford Studies in Literature 19, no. 2/3 (1987): $1-23$ at 13-15.

${ }^{17}$ Maurice Charney discusses the sixteenth-century definition of hyperbole and its importance to Antony and Cleopatra in Shakespeare's Roman Plays: The Function of Imagery in the Drama, pp. 20-29 and 79-81. Janet Adelman in The Common Liar makes an important distinction between the hyperbole used by Philo in the opening speech of the play and that used immediately after by Antony and Cleopatra (1.1.14-17), claiming that they "appeal to two very different modes of belief" (p. 105): whereas we understand that Philo is using metaphor, Antony and Cleopatra are speaking of literal actions (see pp. 105-6). Adelman discusses paradox and hyperbole as "figures that inform the shape and the substance of the play" (p. 111) on pp. 110-21.

${ }^{18}$ For a brief discussion of the style of Philo's opening speech which comes to conclusions different from (but not opposed to) mine, see Markels, Pillar of the World, pp. 154-56. See also Markels, p. 17 for a discussion of how the speech positions the opposition between public and private values.

${ }^{19}$ Markels, Pillar of the World, p. 156.

${ }^{20}$ Markels, Pillar of the World, p. 155.

${ }^{21}$ Perhaps the most obvious and boldest example of this incongruity occurs at the beginning of 2.7.1-15, the party scene on Pompey's galley, when the two servants discuss Lepidus and the other triumvirs with remarkable analogies, culminating in the first servant's surprisingly dense metaphor: "To be called into a huge sphere, and not to be seen to move in't, are the holes where eyes should be, which pitifully disaster the cheeks" (2.7.13-15).

${ }^{22}$ This is already the second reference to Cleopatra's being fanned, the first occurring in Philo's criticism of Antony for being "the bellows and the fan / To cool a gypsy's lust" 1.1.9-10). The third instance takes place in Enobarbus's description of Antony's first meeting with Cleopatra who has at her side boys "With divers-coloured fans, whose wind did seem / To glow the delicate cheeks which they did cool” (2.2.213-14). In both the first and third instances, 
Cleopatra is associated with a paradoxical action, Shakespeare's way of indicating that she is to be considered superior to ordinary mortals and to invite wonder.

${ }^{23}$ In "The imagery of Antony and Cleopatra," Kwartalnik Neofilologiczny 8 (1961): 247-64 at 251-55, Kenneth Muir lists several passages in which "world" and its variations are used. See also Charney, Roman Plays, pp. 80-93. Charney finds forty-five examples of Shakespeare's use of "the world theme"; as a result, he declares:

I shall be particularly concerned with the structural use of the world theme, the way its meanings follow the course of the dramatic action. There are at least three distinct movements in this imagery. Before Actium the world is the material domain of the Roman Empire, in which Antony is a 'triple pillar'; after his defeat there is only the memory of the world lost; and his death marks a devaluation of the world, as if his departure removed its source of value.

(pp. 80-81)

${ }^{24}$ Linda Charnes feels that love "can and must be regarded as inextricable from sociopolitical purpose. ... In 1.1.14-18, we hear what amounts to a theory about love" (Notorious Identity, p. 140); Antony and Cleopatra as they enjoy themselves as lovers "are always simultaneously advancing their own political campaign” (p. 141). However one might agree with her statements conceptually, I am not convinced that her reflections constitute the felt experience of an audience. Given Philo's lead-in to the lovers' four-line exchange, would an audience not be inclined to view the sparring match primarily as an initial characterization of the bond between Antony and Cleopatra, not simply in its abstract, generalized language a "theory about love?" In 1 Henry IV 2.3.34-115 and 3.1.225-60, the scenes of bantering between Hotspur and Kate signify the solidity of their relationship as a committed, loving couple. Arguably, the same is true of the brief exchange between Antony and Cleopatra. For two additional views of love in the play, see David Schalkwyk, "Is Love an Emotion? Shakespeare's Twelfth Night and Antony and Cleopatra," symploke 18, no. 1/2 (2010): 99-130; and David Hillman, "If it be love indeed': Transference, Love, and Anthony and Cleopatra." Shakespeare Quarterly 64, no. 3 (2013): 301-33.

${ }^{25} \mathrm{Or}$, as James Hirsh wittily puts it, "how one views a point of view depends on one's point of view" in "Rome and Egypt in Antony and Cleopatra and in Criticism of the Play" in Deats, New Critical Essays, p. 189. Hirsh's chapter presents a discussion of the values that have come to be associated with the two locales and some that have been left aside; in addition, it explains that, although the values of both Egypt and Rome are imperfect, Shakespeare has invited us to be drawn to the less imperfect set of values of Egypt.

${ }^{26}$ As we shall see in Chapter 6, Shakespeare uses this celebrated signature trait of Antony with pointed irony when Proculeius says, "Cleopatra, / Do not abuse my master's bounty by / Th'undoing of yourself” (5.2.41-43). 
${ }^{27}$ According to her latest biographer, Stacy Schiff, Cleopatra

not only dispensed justice, commanded the army and navy, regulated the economy, negotiated with foreign powers, and presided over the temples, but determined the prices of raw materials and supervised the sowing schedules, the distribution of seed, the condition of Egypt's canals, the food supply. She was magistrate, high priest, queen, and goddess. She was also-on a day-to-day basis and far more frequently-chief executive officer. She headed both the secular and the religious bureaucracies. She was Egypt's merchant in chief. The crush of state business consumed most of her day.

(Schiff, Cleopatra, p. 90)

How much of this Shakespeare was aware of is questionable. Even so, he chooses not to focus on her professional activities but almost exclusively on her personal life-that is, her bond with Antony.

${ }^{28}$ Danby, Shakespearean Dialectic, pp. 199-202, but especially p. 201.

${ }^{29}$ See Markels, Pillar of the World, who notices that "that single word 'liar' takes back all that the rest concedes, and, paradoxically, we are invited to believe both that Antony is in his dotage and that anybody who says so is a liar" (p. 156).

${ }^{30}$ The Folio version is "And get her loue to part." The meaning would then be that Antony would rely on Cleopatra's love for him in consenting to a separation. John Dover Wilson in his Cambridge Shakespeare edition of the play: The Works of Shakespeare: "Antony and Cleopatra" (Cambridge: Cambridge University Press, 1950 ), p. 150 n. 180 suggests that in all probability Shakespeare's manuscript read "leue," meaning "leave,"and was misread by the compositor as "loue." Scholars and editors have accepted this emendation, arguing that "get" more properly fits with "leave" than with "love." See also Marvin Spevack, A New Variorum, pp. 35-36 n. 279 , where he lists the responses to the emendation, beginning in the eighteenth century.

31 Canidius uses a metaphor of labor in childbirth to comment on the amount of news that is born each minute: "With news the time's in labour, and throw forth / Each minute some" (3.7.81-82). But it is witty rather than dramatically intense.

32 Once again we notice how the superfluous phrase "of the world" is used to enhance Antony's fame, even if the context of the statement is one in which Cleopatra is chastising him.

33 See in particular Chapter 4 "The bubble reputation," pp. 87-124 in Anthony Esler's The Aspiring Mind of the Elizabethan Younger Generation (Durham, UK: Duke University Press, 1966).

${ }^{34}$ This is also the sense in which Scarus uses honor, when, in commenting on Antony's flight from the Battle of Actium, he says bitterly, "I never saw an action of such shame. / Experience, manhood, honour, ne'er before / Did violate so itself” (3.10.21-23). Later, Antony tells Enobarbus, “Tomorrow, soldier, / By sea 
and land I'll fight. Or I will live / Or bathe my dying honour in the blood / Shall make it live again" (4.2.5-8). In a footnote to this passage in his edition of the play, David Bevington comments, "The idea of thus invigorating a diseased body gets caught up with the notion of earning eternal fame by heroic deeds of blood" (p. 207). Here, Antony speaks with bravado but out of desperation; like Hotspur, he here uses honor to mean an opportunity for personal glory.

${ }^{35}$ Antony would probably agree with Mowbray's assertion to Richard II, the epigraph for Chapter 3:

The purest treasure mortal times afford

Is spotless reputation. That away,

Men are but gilded loam or painted clay.

(Richard II 1.1.177-79)

${ }^{36}$ Charnes, Notorious Identity, p. 142.

${ }^{37}$ Antony seems to mean just this when he says to Cleopatra: "Of Caesar seek your honour, with your safety" (4.15.48). 


\section{Chapter 5}

\section{"The Varying Shore": Changing Perspectives, Sustaining Illustriousness}

That which is now a horse, even with a thought The rack dislimns and makes it indistinct As water is in water.

Antony and Cleopatra 4.14.9-11

As a chief means of attaining heightened dramatic effectiveness in Antony and Cleopatra, Shakespeare continually depicts unexpected shifts and variations in perspectives among both the major and minor figures. Their diverse points of view are especially noticeable in considerations of standards of measure and frequently grow out of an allegiance to one of the two predominant cultural locations of the play, either Rome or Egypt. ${ }^{1}$ For both reading and viewing audiences, the variations in perspective are complicated by the shifting categories of response detailed in Chapter 1's discussion of Shakespeare's kinetic characterizations. The dramaturgical device of constantly mutating viewpoints would seem perfectly standard were it not for the kinetic characterizations, Shakespeare's longstanding preoccupation with perspective, ${ }^{2}$ and the difficulty that, when considered realistically, the motives for the changes in the characters' cognitive stances are often left obscure. Two of the most obvious examples of the latter are Cleopatra's flight during the naval battle at Actium, and Antony's decision to challenge Octavius, having acknowledged the truth of the Soothsayer's warnings that he cannot win against the younger triumvir (2.3.10-38); both examples tease our imaginations and invite us to speculate on psychological motivations.

It is no surprise that the play's five main figures give ample voice to frequent changes in perspective. The shifts in Cleopatra's mood, as perceived by Antony, can be baffling (e.g., "How, my love" [1.1.26] and "How now, lady" [1.3.39]), and his accusations of Cleopatra's betrayals 
surprisingly naive (e.g., 3.13.107-71 and 4.12.18-49); moreover, as he complains to Octavia, the shift in attitude indicated by Caesar's hostile actions perplexes him and makes him angry (3.4.1-10). The changes in Antony's views, whether the result of unthinking, impulsive behavior, are well noted by Octavius (e.g., in 1.4), Cleopatra (e.g., "Though he be painted one way like a Gorgon / The other way's a Mars" [2.5.118-19]), ${ }^{3}$ and Enobarbus, who in speaking to Cleopatra of Antony's flight from the sea battle at Actium, asks:

What though you fled

From that great face of war, whose several ranges

Frighted each other? Why should he follow?

The itch of his affection should not then

Have nicked his captainship, at such a point,

When half to half the world opposed, he being

The merèd question.

$(3.13 .4-10)$

Enobarbus, like Octavius before him, in using the phrase "the itch of his affection," may be succumbing to the common Roman notion of Antony's "affection" as merely sexual. ${ }^{4}$ The phrase entertains in the wittiness of its disdain. But because of the uncertainty of the referent of "itch," including the unlikely assumption that Antony's motive could be reduced to a sexual impulse, the metaphor only clouds our understanding of his psychology. Taken as a whole, the sheer number of invisibly motivated, shifting stances throughout the play can seem even more puzzling and overwhelming to a theater audience subject to a rapid dramatization of events than to the characters in the world of the play, especially during the middle portion where multiple events take place swiftly and at times are portrayed elliptically.

Changes in outlook occur most markedly as Antony, Cleopatra, Enobarbus, and Charmian are dying. But, with the exception of Octavius, whose truest, most unvarying perspective consists of an ego unstoppably in quest of power and fame, ${ }^{5}$ many unforeseen perspectives present themselves throughout the play. Examples are too familiar and abundant to enumerate in detail. But to suggest their range and diversity, we need only recall such surprising occurrences as: Pompey's response to Menas's proposal, indicating Pompey's consciousness of measuring up to his selfconceived public image (2.7); Ventidius's realistic characterization of his "lower place," another clear indication of how one's image is measured and 
perceived, both publicly and privately (3.1); Eros's stunning decision, the ultimate sacrifice, to kill himself instead of Antony, an act that verifies the genuineness of his wholehearted loyalty and devotion to his master and, in its exaltation of a deep bond, speaks to measuring up to the norm of hyperbole in the play and to Antony's worth as a leader (4.14); the schoolmaster emissary who is utterly inept at negotiating with Caesar, an example of one who does not measure up and who knows it (3.12); and, given Antony's declaration to Cleopatra of Proculeius's trustworthiness, the unexpected stances of both Proculeius and Dolabella (5.1 and 5.2), which offer a contrast in perspectives-Proculeius's imposed by sociopolitical influence and Dolabella's motivated privately by genuine compassion, but both views indicating a concern with measuring up.

In the opening scene of the play, Shakespeare reveals another aspect of his artistic interest in dramatizing alterations in cognitive modes, this time focusing on creating a difference between a perspective within the world of the play and that of the audience viewing it. When Antony and Cleopatra make their first appearance, Philo and Demetrius seem to see and hear less than reading and viewing audiences do. As we saw in the last chapter, in the simplicity of their Roman biases and their culturally ingrained standards of measure, they arrive at moralistic conclusions no different from those Shakespeare's earliest audiences would likely have believed. Focused solely on the wellbeing of Antony's professional duties and former reputation, Philo and Demetrius's vantage point prevents them from imagining, let alone seeing, a subtext in which bonded love, not simply lust, is of prime importance and in which the relationship of the two lovers is complicated by irreconcilable differences in the value systems of Rome and Egypt; of course, they are not able to conceive of Egypt's possessing a value system. By the end of the scene, the two Romans apparently have acquired no new understanding based on what they have actually just seen and heard. But, presumably, the audience has understood that the banter between the protagonists pertains to more than a relationship of lust. In effect, the two Romans have responded with shallow, preformed criteria, what Cleopatra might characterize as the inferior result of Roman brain washing. Their reductive response appears to be the consequence of an unthinking, deductive form of cognition rather than a more thoughtful and pragmatic inductive mode. As such, their response would seem to tell us something about Shakespeare's personal preference for one perspective over the other and maybe it does. But since both Antony and Cleopatra err when they respond inductively, often because they respond 
precipitously and irrationally, we know that there can be pitfalls-for example, Antony's knee-jerk reaction to Thidias (3.13) and Cleopatra's explosive, displaced anger at the messenger who tells her of Antony's marriage (2.5).

As anyone familiar with the history of the lovers well knows, other drawbacks complicate the characters' inductive perceptual mode. We see again and again how emotion can replace reflection and can lead to selfdeception. Antony's rashness and self-absorbed efforts at glorifying his heroic image can lead him to misjudge the political or military reality of his present context, as he does, for example, in his mistaken condemnations of Cleopatra (3.13.107-71 and 4.12.18-49), his disregard of the Soothsayer's pronouncements (2.3.10-30), and his challenge of single combat to Octavius (3.7.30 and 3.13.20-38). Cleopatra falls victim to the same psychological failing, because she almost always disregards the sociopolitical forces engulfing Antony in order to further her own desires, thereby misconceiving the inexorable destructive power of world politics and the need to engage with it. As a consequence of being deceived by their own misperceptions, both lovers become caught in descending spirals. Even so, it becomes increasingly apparent that the play revels in those moments when they more than measure up, transcending their downward trajectory and achieving feats that indicate why they qualify as prime examples of the immortalizing power of fame. Ironically and paradoxically, however, these feats are more often related than portrayed, especially Antony's. Philo (1.2.2-4 and 6-8), Caesar (1.4.57-72), and Cleopatra (4.15.65-75 and 5.2.86), for example, suggest the hero's extraordinary feats and Maecenas, Agrippa, and Enobarbus (2.2.195-250) give voice to the rarity of Cleopatra's powers, and, later, Charmian (5.2.320-21), and even Caesar (11. 329-31 and 340-42) make clear the monumentality of the Queen's suicide.

Shakespeare frequently enables us to detect his understanding of the cognitive ingredients that shape the characters' perspectives: reason, emotion, imagination, intuition, and the insight that results from intuition. In A Midsummer Night's Dream, Theseus gives us two generalized, categorical perspectives, "comprehending" and "apprehending" (5.1.2-27). Shakespeare retains these same two categories in Antony and Cleopatra but complicates them through the multiple situations that he portrays. Both of these perceptual modes can create outlooks that are either illuminating or blinding, depending upon the situation and the context. Cleopatra, through a heavy reliance on emotion, imagination, and intuition, and 
Caesar, who invokes reason abetted by detachment, come closest to establishing stable outlooks, but the closer they come, the clearer the limitations of their opposed perspectives become. Cleopatra is too focused on her individual desires and needs and Octavius is too focused on acquiring power in the guise of society's needs and desires, prohibiting him from achieving the expression of humanity embedded in mutual bonding, a principle that Shakespeare's writings as poet and dramatist tirelessly extol. Not surprisingly, given his profession as a writer, in his depiction of cognitive modes the playwright considers the imagination as a way of knowing. As such, it can enhance with subtlety one's perspective, as it does Cleopatra's, especially after the death of Antony. But the imagination can also be a source of self-deception; Pompey all too confidently demonstrates this when he surmises that the effect of the relationship between the lovers will keep Antony in Egypt and away from Rome (2.1.1-16). No one perspective is thoroughly reliable, much less stable; we understand this fundamental truth from the characters' several failed attempts to advance their struggle for selfhood by measuring up to their self-styled notions of it. The readers and spectators who experience the play also share a parallel difficulty. They struggle to measure up as readers and spectators because of the multiple ambiguities in characterization, language, and plot incidents. Given this condition, we not only understand the sources of the reading or viewing audience's problems in responding to the text but also the reasons for the critical controversy surrounding the play. However, at the same time, we have an implicit but clear aesthetic explanation for the play's insistent dramatization of the uncertainties encompassing shifting perspectives; whether in the audience's search for motivating causes or the reasons for abrupt shifts or elusiveness, the difficulties baffle and captivate us, promoting an engagement that mixes reflection with emotion.

Thus, it would seem that when it comes to forming a workable perspective on the play's morass of perspectives, audiences have difficulty in part because they are overwhelmed by the confusions inherent in the clashing of viewpoints. What, for example, are we to make of the overriding paradox that the perspective we are drawn to emotionally, glorifying the lovers individually and as a bonded union, is less successful than the one that inevitably is successful, Octavius's triumph? For all their defects, we side with the lovers and their bond against the ruthless but victorious machinations of Octavius. A related complication that compounds the difficulty, as Janet Adelman puts it, is that "The stage action necessarily presents us with one version of the facts, the poetry with another. We can 
neither believe nor wholly disbelieve in the claims made by the poetry." ${ }^{6}$ Yet, contradictorily, by the end of the play many viewers and readers have become so enamored of the verbal displays of Shakespeare's imagination operating at its magnificent best that, like Antony and Cleopatra, they manage to settle on a perspective of uncritical acceptance and find a way to believe "in the claims made by the poetry." That is, they stand in awe of the two protagonists, admiring them for what they have achieved and disregarding what they have not, ending perhaps in a misperception, but a felicitous one.

This apparent paradox requires some additional explanation, for it is most in evidence at the conclusion of the drama. However, before reflecting further on the sources of readers and viewers' final responses to the drama, let alone those of critics and directors, we need to understand more fully Shakespeare's perspective on perspective. The following passages are representative examples of the playwright's preoccupation with the complexity of perspectives, portrayed in the acts and words of his characters and serving ultimately and inescapably as fodder for the content of the play.

First, when Antony dares Octavius to a one-on-one combat (3.13.2528), we understand that the challenge comes from a past Roman code of ideal heroic behavior that Antony still subscribes to-unrealistically, as it turns out. Given Octavius Caesar's hard-bitten temperament and present successful course of action as a dominant ruling force in the Roman Empire, we can easily infer that he would be scornful of such a code. As it is, he rejects Antony's challenge to personal combat with a snide reference to the hero's age, saying, "Let the old ruffian know / I have many other ways to die, meantime / Laugh at his challenge" (4.1.4-6). Octavius's perspective here is the opposite of his attitude toward Antony's Roman valor earlier in the play when, in recalling the aftermath of the warrior leader's slaying of the consuls Hirtius and Pansa (1.4.57-72), he extolled Antony's unique heroic actions, even though those actions belonged to a code of professional behavior radically different from his own. ${ }^{7}$ The earlier speech of praise may well be an example of what I have described as Shakespeare's employment of Octavius as a functional rather than a realistic figure. Because of the difficulties of staging Antony's past achievements, Shakespeare needs someone to praise enthusiastically Antony's heroic deeds and who more striking than the man who is usually his severest critic? Even so, the contrast in perspectives between Antony and Caesar and between the latter in Act 1 and in Act 4 suggest Shakespeare's 
aesthetic interest in dramatizing opposed and confused viewpoints without feeling any obligation to resolve them.

Second, in assessing Antony's challenge to Octavius, Enobarbus believes that Antony has made "his will / Lord of his reason" (3.13.3-4) and, in an aside, reveals from a pragmatic, rational, Roman perspective his incredulity that his leader "should dream, / Knowing all measures, ${ }^{8}$ the full Caesar will / Answer his emptiness" (3.13.34-36). Enobarbus has just remarked in the same aside, "I see men's judgements are / A parcel of their fortunes, and things outward / Do draw the inward quality after them / To suffer all alike" (3.13.31-34). The observation is a commonplace, but it serves to point emphatically to the inextricable relationship between one's fortunes and one's "judgements"; it also sounds the solemn note that external forces, over which one has no control, are omnipresent and omnipotent, often to the detriment of the formation of one's attitudes. Noticeably generalized, Enobarbus's sententious reflection carries with it Shakespeare's sense of how little effort it takes to change one's perspective, and, more especially, the ease with which one's perspective can become distorted.

Third, not all the dramatizations of conflicting perspectives in the play have such public consequences as Antony's challenge to Octavius, but Shakespeare nevertheless manages to make even the most extreme personal changes in perspective universal. In reacting to the news of Fulvia's death, Antony says to himself,

There's a great spirit gone! Thus did I desire it.

What our contempts doth often hurl from us,

We wish it ours again. The present pleasure,

By revolution lowering, does become

The opposite of itself. She's good being gone;

The hand could pluck her back that shoved her on.

(1.2.119-24)

This passage speaks to contradictory changes in private perspectives and, concomitantly, to reversals in values. It also characterizes the inevitability of change itself. Later in the same scene, Antony tells Enobarbus that

Our slippery people,

Whose love is never linked to the deserver Till his deserts are past, begin to throw Pompey the great and all his dignities Upon his son ...

$(1.2 .178-82)$ 
In the following scene Antony explains to Cleopatra,

Equality of two domestic powers

Breed scrupulous faction; the hated, grown to strength,

Are newly grown to love ... $(1.3 .47-49)$

And quietness, grown sick of rest, would purge By any desperate change.

$(1.3 .53-54)$

Caesar echoes this statement when he declares to Lepidus:

It hath been taught us from the primal state

That he which is was wished until he were:

And the ebbed man, ne'er loved till ne'er worth love,

Comes deared by being lacked. This common body,

Like to a vagabond flag upon the stream,

Goes to and back, lackeying the varying tide

To rot itself with motion.

$(1.4 .41-47)$

Antony's speeches to Enobarbus and Cleopatra and Caesar's to Lepidus all delineate sociopolitical changes in perspective, especially the fickleness of the common people, and, inevitably, the widespread consequences of such changes. In dramatizing Antony's awareness of both private and public perspectives, Shakespeare enhances the characterization with a deep sensitivity and intelligence that, understandably, belong with the protagonist's heroic nature. Moreover, the suddenness with which Antony moves from one perspective to another creates audience interest in the wrenching struggle he continually undergoes.

All of the above passages have in common the inevitability of flux. Like events, perspectives continually dissipate only to form new perspectives. In conjunction with the rapid turn of events throughout the play, Shakespeare impresses upon us the unavoidable conditions resulting from the law and process of incessant change. Time in one place melts ambiguously into time in another: as "indistinct / As water is in water" (4.14.9-10). While Antony is partying on Pompey's galley, Ventidius has succeeded in vanquishing the Parthians, and while Octavia is in Rome to mediate between her husband and her brother, Antony is in Alexandria 
bestowing additional power on Cleopatra. Such elliptical portrayals of movements of time in different places prevent an audience from fixing a perspective on either the events or the characters. The effectiveness of this device lies in giving us a felt experience of the difficulties the characters endure in their attempts to locate and cling to a perspective, especially one that successfully enables them to measure up. Thus, when characters are able to firmly maintain an admirable perspective for any length of time, aided by the magniloquence of Shakespeare's language, we are more willing to admire them than not. As we shall see, this situation occurs most emphatically when Enobarbus, Antony, and Cleopatra are in the throes of death and flux is no longer a consideration.

We have already noticed that Shakespeare evinces a predilection for dramatizing the interplay between non-judgmental, purely psychological points of view and strongly judgmental moral perspectives. ${ }^{9}$ This tendency occurs both early and late and in his poetry as well as in his plays. ${ }^{10}$ In Antony and Cleopatra, he skillfully fashions situations and characterizations to create two related perceptual contrasts: (1) the clashes of moralizing and amoral perspectives among the characters and (2) in a frame of reference both within and outside the play, the more enveloping but overlapping opposition between moral and psychological understandings of human behavior, with which, as a dramatist creating characters, Shakespeare himself appears seriously concerned; this artistic preoccupation alerts his audiences not only to its importance as a modus operandi in portraying characters, but also to its manifestation as a significant issue emerging from within the play. The playwright makes the first conflict a fundamental cause of political and military disruption in the world of the play and crucial to our comprehension of the processes of establishing standards in measuring up and achieving permanent renown. He reveals through the second conflict a principle and context that are essential to his own artistic sensibility and practice, and that, inadvertently, also help to account for his own imperishable fame.

The conflict between Roman moralizing and Egyptian amorality results in systems of value that are complicated, confused, contradictory, and even unstable-hardly "systems" at all. Confirming the values it stands for, the play appears to favor one predominant strain of the amoral perspective, what might be called the aesthetic perspective, even if not in a specifically artistic context. I am using "aesthetic" to mean both involuntary and voluntary sensory perceptions and the emotions that attend such perceptions, arrived at intuitively rather than through rational means. 
For all his political hypocrisy, Octavius Caesar is nevertheless the prime exponent of the moralizing perspective and Cleopatra the most ostensible example of the aesthetic amoral perspective. One might argue against making a distinction between moral and aesthetic viewpoints, asserting that an aesthetic eye is able to incorporate a moral perspective when the former contains within it an implicit or explicit evaluation such as Cleopatra's initial attraction to and consequent love for Antony, and that a moral outlook can make good use of an aesthetic perspective as long as the latter does not disrupt the focus. With regard to the above-mentioned second dichotomy concerning the opposition between moral and psychological understandings of human behavior, a similar objection against separating a moral from a psychological perspective could be made, positing that the latter can encompass the former. In theory, then, each of the two dichotomies can be perceived as falsifications. But Shakespeare poses the two conflicts in Antony and Cleopatra, and ultimately for himself as dramatist, so that neither one can be collapsed into a single configuration. The play continually depicts the limitations of the moralizing perspective, beginning with its narrowness and continuing with its hypocritical use in political situations. The more encompassing aesthetic perspective, though tenable when the fullest degree of personal pleasure is desired, especially in amatory activities taking place in Egypt, carries little weight in a sociopolitical context where, of necessity, a pseudo or actual moralizing perspective prevails and where ultimate control lies.

I have spoken almost exclusively of Roman moral values associated with Octavius's perspective. But it has become evident by now that Antony endorses Roman values of a different, much older order. Even if there were no Cleopatra, Octavius's observation about his and Antony's relationship would still hold true: "for't cannot be / We shall remain in friendship, our conditions / So differing in their acts" (2.2.119-21). Antony's values are clearly more idealized, heroic, and humane; they partake of emotional and physical release just as Octavius's partake of canniness, restraint, and austerity. The warrior leader's human values are opposed to the ruthless, self-aggrandizing principles that Octavius lives by and that are eminently successful-an irony that Shakespeare makes indelible. The contrast between an older and a newer order of values has been present in Shakespeare's dramas at least since As You Like It where Orlando praises Adam for belonging to an older, better order:

O good old man, how well in thee appears

The constant service of the antique world, 


\begin{abstract}
When service sweat for duty, not for meed! Thou art not for the fashion of these times, Where none will sweat but for promotion, And having that, do choke their service up Even with the having; it is not so with thee.

$(2.3 .56-62)$
\end{abstract}

In Othello, Iago makes clear his preference for the newer order of values (1.1.41-64), declaring in a cynical assertion of self-interest over loyalty in matters of service that he will not wear his heart upon his "sleeve / For daws to peck at" (1.1.63-64). In King Lear, the contrasts between Kent and Oswald and between Gloucester and Cornwall in their attitudes toward serving Lear make the same point. Clearly, Goneril, Regan, Oswald, Edmund, and Cornwall stand for the new order just as Cordelia, Kent, Gloucester, Edgar, and Albany stand against it.

Moreover, Shakespeare's portrayal of the moralizing and aesthetic perspectives as conflicting is by no means restricted to Antony and Cleopatra. In 1 Henry $I V$, for example, Falstaff could be said to represent the aesthetic perspective, whereas the reformed Hal stands for the moral perspective. Here, the playwright avoids the more conventional dichotomy between moral and immoral perspectives to set before us a conflict of values created by the opposition between moral and amoral perceptions, the latter being specifically characterized as aesthetic ("playing holidays" 1.2.197). Hal has to set aside his aesthetic perspective in order to embrace a moral one. Falstaff never does. As in Antony and Cleopatra, the two perspectives are made mutually exclusive.

The second contrast, between moral and psychological understandings of human behavior, emerges within Antony and Cleopatra as one in which the characters possess some instinctive but little rational awareness of their perceptual modes in understanding human behavior; however, the contrast has firm roots in Shakespeare's artistic consciousness. Through the playwright's employment of kinetic characterizations and given the fluctuations in the way the viewing and reading audiences perceive the dialogue that results, Shakespeare frequently brings before us the differences between moral and psychological approaches to facilitate understanding and assess human behavior. As we have already seen, Octavius almost always adopts a moralizing stance when he speaks (e.g., in 1.4). The psychological viewpoint is less reductive and biased, and more tolerant. Although infrequently represented by the characters in the play, it nevertheless surfaces at times, and not only through Cleopatra's insights- 
e.g., "Thou teachest like a fool: the way to lose him" (1.3.10), "Some innocents scape not the thunderbolt" (2.5.78), and "wishers were ever fools" (4.15.38) - but through Enobarbus's. A clear example occurs when Antony seems to be taking leave of his servitors (4.2). Surprised and puzzled, Cleopatra asks Enobarbus, "What means this?" (4.2.14). He answers with sharp psychological insight, "'Tis one of those odd tricks which sorrow shoots / Out of the mind" (4.2.15-16).

Still another telling instance involves the Battle of Actium. But this example illustrates a conclusion that Shakespeare invites his audiences, not his characters, to draw. Before the battle, Canidius, Enobarbus, and an anonymous soldier all argue against an engagement at sea, encouraging Antony to conduct a less risky fight on land (3.7.19-69); they assert their moral position forcefully, and Shakespeare emphasizes it in the dialogue immediately following the exit of Antony, Cleopatra, and Enobarbus:

Soldier: By Hercules, I think I am i'th'right.

Canidius: Soldier, thou art; but his whole action grows

Not in the power on't. So our leader's led,

And we are women's men.

$(3.7 .67-70)$

The soldier's oath ("By Hercules") is a reminder of Antony's supposed ancestor, making the emperor's decision to fight by sea seem all the more wrongheaded for not acting from his obvious strength. The moralizers are ultimately right; Antony does lose the battle, but not for the reasons they have suggested. The couple was in fact winning the battle before Cleopatra suddenly darted away. They lost the battle because, upon impulse, Antony followed Cleopatra for inexplicable psychological reasons, not because of the superficial moral suppositions of Canidius, Enobarbus, and the soldier. Thus, Shakespeare undermines the moralizing mode, including the soundness and finality of purely moral judgments, by viewing the episode from a psychological perspective replete with ambiguity. Fate seldom allows moral pronouncements to become authoritative, for it controls the passage of time and change. Ultimate reality lies in change and the good and bad fortunes it carries with it.

Because the playwright knows that the juxtaposition of contrasting moral and psychological perspectives can be a valuable means of evoking audience engagement, he readily embraces it. Nevertheless, in his own mind, the conflict admits of resolution, for, in depicting human behavior and in spite of opposing cultural mores, he firmly upholds an inclusive 
psychological perspective over a limited moral one, although the two perspectives can be entwined in complicated, inseparable ways-as Antony repeatedly demonstrates. In a viewer's or reader's response, psychological understanding not only allows for greater complexity and increased consciousness; it also provides a powerful source of engagement because of its unquestioned transhistorical legitimacy as our most fundamental and readily accessible entry into the relationship between cause and effect in human behavior. In addition, it provides opportunities for truthful ambiguities about the behavior of Antony and Cleopatra that have kept readers and spectators fascinated for centuries and, as a consequence, has enabled the fame of the protagonists to continue to burn brightly. At times, Shakespeare asks us to respond to Antony and Cleopatra through a non-evaluative psychological lens, but, simultaneously, audiences are always aware that the Romans view them exclusively through a harshly critical, moralistic one. Hence, the conflict. This conflict may or may not reflect Shakespeare's personal stance against an overwhelming moralizing tendency in his culture; but, essentially, the playwright leaves this dilemma for his audience to resolve rather than his characters, who, even if they sense such differences in perception, lack an audience's conceptual understanding of the dichotomy and their ability to evaluate it. Moreover, Shakespeare effectively evokes frustration and distress in his audiences because of the uncomfortably real perception that the shortsighted $\mathrm{moral} / \mathrm{moralizing}$ perspective is so pervasive. Thus, by setting in opposition a moral and a psychological understanding of human behavior, the playwright manages to favor his psychologizing tendency but not without also providing tension for the audience, essential provender for any powerful drama.

In discrediting the effectiveness of the moralistic perspective, Shakespeare may have been influenced by Christopher Marlowe. Marlowe's plays and poetry not only resist didacticism, but they show moralizing to be ineffectual-maybe in part due to the influence of Ovid. These tendencies lead to the likelihood that Marlowe's chief interest is in entertainment, not in conveying a message or in promoting ethics either as subject matter or as a satisfactory mode of discourse. ${ }^{11}$ Shakespeare's similar interest is not as undiluted as Marlowe's, for we do emerge from his works with some sense of values, especially in bonding human relationships. But, as we have already seen exemplified in Antony and Cleopatra, he nevertheless seldom tires of dramatizing situations in which moral advice proves to be worthless. ${ }^{12}$ 
In favoring psychological understanding throughout Antony and Cleopatra, Shakespeare manages to subvert the judgmental perspective of his primary source, Plutarch, ${ }^{13}$ and the many other classical, medieval, and Renaissance writers who also looked upon the tale of the two lovers as an opportunity for moralizing and making primarily negative judgments. ${ }^{14}$ Shakespeare's preference for psychological over moral portrayals might well be a warning to those modern critics who try reductively to put Antony and Cleopatra into moral categories rather than accepting the lovers non-judgmentally and, at times, ambiguously as psychological studies. Because they are figures captivating in their human weaknesses and wondered at for their godlike characteristics, Shakespeare in effect calls upon us to be flexible in our perspectives, including our willingness to keep shifting our attitudes, so that he can furnish us with unrestricted sources of emotional pleasure and intellectual stimulation.

In Antony and Cleopatra, the conflict between the moral and aesthetic perspectives is neither clear-cut nor simple. By examining how this conflict engulfs the chief figures of the play, we can see how Shakespeare takes dramatic advantage of the opposition. In her relations with others, Cleopatra's shifts of mood in her behavioral roles are frequently impelled by a wholly instinctive impetus, lacking ethical bias. But such spontaneous acts do not mean that she has not made aesthetic judgments previously. Clearly, her exaltation of Antony and the foregrounding of their relationship are governed by an aesthetic, non-moral judgment. Her all-absorbing love for Antony remains the chief motive in her energydriven actions and reactions for most of the play. Her questioning of the messenger about Octavia (3.3) is a case in point; her assessment of her rival demonstrates, not without the comic irony that results from her willingness to be self-deluded, a thoroughly instinctive behavior and an absence of the moral principle and rational detachment that, presumably, attend ethical judgments. At the end of her life, however, as Cleopatra is preparing for her suicide, she utters comments that suggest that she is strongly motivated by a serious, thoroughly praiseworthy, "noble" moral purpose, one that principled Romans of Antony's persuasion could not help but admire: speaking of Caesar, she says, "He words me, girls, he words me, that I should not / Be noble to myself" (5.2.190-91); in commenting on either the country bumpkin or the basket with the asps (the text is not clear), she exclaims, "What poor an instrument / May do a noble deed" 
(5.2.235-36); and in fortifying herself for the act of suicide, she creates in customary fashion a brief dramatic scenario to cheer herself on: "Methinks I hear / Antony call. I see him rouse himself / To praise my noble act" (5.2.277-79). By the conclusion of the play, she has enlarged her vision to include both perspectives and then proceeds to satisfy the moral and aesthetic demands she herself has set. This newly integrated perspective results in her most dignified act of measuring up and raises her stock as a famed historical figure who is extraordinary and thoroughly worthy of admiration. It also allows us to characterize her overall scheme of values as very pragmatic, expedient, and generously pliant. At the outset of the play, her assertion of the superiority of one's private life seems to present a limpid contrast to Octavius Caesar's insistence on the superiority of the political state. But we quickly come to understand that his moral position and moralizing actually constitute a hypocritical glossing over, for he is rigidly focused on power and the enduring fame that power enables, standards of measure that are self-interested even if they are made to seem or, by chance, actually are altruistic. In both characters, the initially clear and simple conflict between aesthetic and moral perspectives evanesces as we become familiar with the differences and complexities of two distinct temperaments, Cleopatra's more so than Octavius Caesar's.

Antony manifests the severity of the conflict of moral and aesthetic perspectives as well as the resulting unsettling of any clear system of values. The play would have us believe that his past record of heroic deeds, presumably executed in part in service to the state but primarily as superhuman feats of personal glory, led him to a clearly established system of values. But once he arrives in Egypt, he experiences a conflicting perspective and set of values that initiate a pattern of wavering in his allegiance to both Cleopatra and to Caesar. Further complicating this situation are those immoderate natural tendencies in Antony that equip him for participation in both sets of values. Such hyperbolic proclivities as his energy, persistence, magnanimity, and ability to inspire love and devotion, as well as his adherence to an older, idealized scheme of Roman values, etch a figure distinctive enough to achieve enduring fame.

Antony's vacillation convinces us that conflicts of perspectives and value systems are responsible for political disarray in the world as well as for an inevitable destructiveness in personal relationships. The dual conflicts also make standards of measure difficult to establish, let alone sustain. As the discussion of honor in the last chapter exemplifies, the Roman values Antony espouses are subject to skepticism, no matter how rational 
and necessary they are made to seem. In part, doubt is created because Antony's values seem to belong to an old-fashioned past and, inescapably, clash sharply with those of the present realpolitik. In addition, as a result of Octavius's ruthless exploitation of supposedly traditional Roman values, we frequently view the youngest triumvir's values as either paperthin or hollow, simply a political veneer of hypocrisy covering what we have identified as an unquenchable egotism and a relentless drive for power through self-aggrandizing actions. In spite of Antony's outburst at the beginning of the play ("Let Rome in Tiber melt"), he is no more secure in espousing the values associated with his love for Cleopatra than he is in attempting to adhere to old-style Roman values. At his death, Antony tries to combine the two systems of Roman and Egyptian values by conflating the high-minded Roman way in which he dies, through suicide, and his past heroic achievements with a major Egyptian reason for suicide, his love for Cleopatra. But we are nevertheless left with a nagging question: Does his previous shifting behavior undermine his success at uniting differing value systems, making the combination seem all too artificial? The elevated grandeur of the language as he is contemplating his death and as he is dying would suggest not. But does the language accurately reflect the situational reality behind Antony's words?

At the end of the play, Octavius commends Antony and Cleopatra but with enough vagueness so that we are not sure from his perspective wherein their greatness lies; he proclaims, "No grave upon the earth shall clip in it / A pair so famous" (5.2.353-54). But "famous" for what? The words in these lines and the elevated tone they produce convey a tribute to Antony and Cleopatra. But the tribute seems more Shakespeare's than Caesar's, because, in desiring to end the play with a final exaltation of the lovers, the dramatist uses language that recalls the style of earlier magniloquent passages: "upon the earth" is extraneous as far as the meaning is concerned but in its emphasis and enveloping grandeur ("earth") it helps to exalt Antony and Cleopatra in much the same way the repeated phrase "of the world" and the cosmological imagery have elevated them earlier; ${ }^{15}$ "clip" is the same word of epic diction Shakespeare last used in 4.8.8, another singularly momentous occasion; and the word "pair" reminds us of Antony's phrase "such a mutual pair" (1.1.40) in which the triumvir elatedly proclaimed the extraordinary bond of two exceptional people. Octavius's reference to Antony and Cleopatra as a "pair" and his intention to place them side-by-side together in a grave may suggest that he is cannily limiting his tribute to the bond of love between them. ${ }^{16}$ All we can be 
sure of, however, is that he is acknowledging their fame. ${ }^{17} \mathrm{He}$ is, of course, at the same time proclaiming his own:

High events as these

Strike those that make them; and their story is

No less in pity than his glory which

Brought them to be lamented.

$(5.2 .354-57)$

As Shakespeare's audience, our reaction to the lovers differs from Octavius's evasiveness in establishing for posterity "the world's report" (2.3.5) of their fame. Given the broad scope of our perspective, we willingly accept Antony's fame as an epic hero and the mix of his and Cleopatra's fame as political discontents and exceptional, devoted lovers, "such a mutual pair / And such a twain" (1.1.39-40).

Throughout the play, we have been invited to consider the lovers aesthetically, psychologically, and morally, with approval as well as disapproval, and to absorb the complexities, limitations, ambivalences, and ambiguities of their characters as they struggle to fix standards of measure and set in place a workable system of values. Our inability to circumscribe our overwhelmingly numerous reactions to Antony and Cleopatra, including those that are ambivalent, suggests that for Shakespeare himself the chief system of values lies in having the audience find an aesthetic pleasure in perceiving the changes in the lovers, rather than coming to a final, moral determination about their behavior. Whether we approve or disapprove of their behavior based on rational grounds, he is striving specifically to evoke in us awe or wonder, a basic ingredient in perpetuating fame. Consequently, reflective audiences may well emerge with a greater awareness of the operation of their own cognitive faculties and the advantages and limitations of psychological understanding, perhaps valuing less what their cognitive faculties are able to conclude than the mechanics of the process.

One of the most obvious ways in which Shakespeare sustains a focus on how his characters perceive and on the personal and cultural complications, large and small, that ensue from differing perspectives is through his dramatization of numerous attitudes in the play toward food and drink. ${ }^{18}$ The importance of the subject is suggested by its use in depicting Antony and Cleopatra's first encounter. Enobarbus describes the lovers' meeting as 
beginning with an invitation to "supper" (2.2.230), extended by Antony. But Cleopatra counters with an offer of her own, entreating that "It should be better he became her guest" (2.2.231), and, with her usual imaginative flair and, presumably, in accordance with the Egyptian custom of luxuriousness, transforms the "supper" into a "feast" (2.2.234). In trumping Antony's invitation, Cleopatra reveals some of her most salient traits: her desire to assert her control in her dealings with other people (presumably exercising a certain degree of political power as well as personal charm in this instance), her pride in displaying a regal splendor through pleasurable magnificence, and her method of enticing Antony and holding his interest by crossing him. In his narrative, Enobarbus humorously claims that "Our courteous Antony / Whom ne'er the word of 'No' woman heard speak, / Being barbered ten times o'er" (2.2.232-34) goes to the feast "and for his ordinary pays his heart / For what his eyes ate only" (2.7.235-36). Given Antony's generous nature, it is no surprise that he would recognize and appreciate Cleopatra's generosity and be particularly receptive to her for manifesting it. Even though he is married, Antony is nevertheless as eager to be amenable to Cleopatra's charms as she is to display them. In Egypt, pleasure, not moral fastidiousness, reigns, as the playwright's use of a festive meal suggests. That Shakespeare does not make a moral issue of the situation indicates that his chief interest lies in characterizing a perception of a culture in which, ideally, personal relationships are of fundamental importance and their conjunction with pleasure essential. Cleopatra's conversion of Antony's supper into a feast epitomizes not only the positive desire to form a social bond so basic to Egyptian culture, but, given Antony's position as ruler, it also offers an inescapable political advantage to the Queen as well as to her eminent guest. Thus, to see the extravagance of feasting as self-indulgent and frivolous, as both Pompey and Octavius undoubtedly would, ${ }^{19}$ would exemplify a narrow moralistic perspective that misses the broader psychological, political, and cultural implications of the event.

Octavius consistently views the intake of food and drink as a measure of professionalism. He therefore criticizes Antony's heroic diminishment in part as a consequence of drinking too much (1.4.4) and consorting with unsavory companions ("tippling with a slave" 1.4.119). From Octavius's point of view, a luxurious indulgence in food and drink is despicable, whereas a spare diet can be a sign of control and even lead to heroic behavior. ${ }^{20} \mathrm{He}$ commends Antony's forced dietary restraint after the battle at Modena (1.4.56-72), and on board Pompey's galley expresses 
his disapproval of drinking (2.7.91-96 and 107-19); to his mind, drinking promotes a loss of control and one's reasoning abilities, as well as a distortion of reality: "It's monstrous labour when I wash my brain / And it grow fouler" (2.7.92-93). When Antony tells Octavius, "Be a child o'th'time" (2.7.93), Octavius answers defiantly that he would rather "Possess it" (2.7.94) - that is, exert control over the operations of time, which too much drink prevents. ${ }^{21}$ Immediately after, assuming a perspective that could not be more opposite, Enobarbus suggests they "celebrate" (2.7.98) drinking with a song and a dance. For him and for Antony, fresh from their sojourn in Egypt, drinking is a natural form of pleasure and, as such, should be consecrated. It signifies the means to uninhibited joy-at least, temporarily - for it is even able to "drown consideration" (4.2.46).

Whereas Caesar is consistent in his attitude toward food and drink, Antony reveals time and again that he holds no consistent perspective. Although the warrior leader is able to exclaim joyfully to Pompey that the party on board the latter's galley "ripens" (2.7.90) toward an "Alexandrian feast" (2.7.89), his mention of food later is from quite a different perspective. Early in the play, Cleopatra lavished praise on herself, claiming that for Julius Caesar she was "a morsel for a monarch" and that she bewitched "great Pompey" (1.5.32). Antony echoes the mention of the same two monarchs and even uses the word "morsel" when in a harshly judgmental, Roman mood, he angrily lashes out at Cleopatra, saying, "I found you as a morsel cold upon / Dead Caesar's trencher; nay you were a fragment of Cneius Pompey's" (3.13.119-21). ${ }^{22}$ But his perspective differs so drastically from Cleopatra's and from his state of mind on the galley that we recognize that metaphors of food and drink have an effect of being employed to suggest that how people perceive and why they perceive as they do are ultimately more important than what they perceive. If this observation seems commonplace, it nevertheless deserves mention because it clarifies just how forcefully it was pressing on Shakespeare's consciousness as he composed the play.

At his first appearance, Pompey suggests a connection between food and Antony's abandonment of honor that is less pragmatic than Octavius' notion but equally deleterious:

Let witchcraft joined with beauty, lust with both,

Tie up the libertine in a field of feasts,

Keep his brain fuming. Epicurean cooks,

Sharpen with cloyless sauce his appetite, 
That sleep and feeding may prorogue his honour Even till a Lethe'd dullness-

$(2.1 .22-27)$

Pompey hopes that Antony will be depleted of energy and sink into oblivion from not being able to resist the excess of an "Alexandrian feast" (2.7.89), including becoming drunk from wine ("fuming" [2.1.24]). Unlike Octavius, Pompey does not deny the pleasures of drinking and eating, thereby presenting a viewpoint that only partially overlaps with Octavius's. As we have just seen, Cleopatra associates food and drink with pleasure, enticement, and joy. In addition, she is prone to using food and drink to signify psychological states: whether it is to "drink mandragora" (1.5.3) to eliminate tedium, "feed" herself "with most delicious poison" (1.5.27-28) to counter her loneliness and emotional lows during Antony's absence, or to characterize her "salad days" (1.5.76) when she was inexperienced in the meaning and ways of love. Undoubtedly, the most hyperbolic association of "Egyptian cookery" (2.6.62) with joyful revelry and intense moments of pleasure emerges from Enobarbus' description of the breakfast for twelve people at which "eight wild boars" were "roasted whole" (2.2.191). Even if the cooks had no advance notice of the number of people who would show up and were playing it safe, the excessiveness of eight wild boars strikes audiences with awe as it indicates more generally the Egyptian modus vivendi set by Cleopatra for her court. Antony seeks to recapture this same desire to reach the heights of pleasurable enjoyment when, after the Battle of Actium, he invites "his noble captains" (3.13.193) to a feast, declaring with customary extravagance and gusto, "I'll force / The wine peep through their scars" (3.13.194-95). Thus, in Egypt, food and drink act as a standard of measure to indicate the most lavish high style of pleasure possible. The naturalness of eating and drinking give a sanction to pleasure that is not countered by what Caesar and Pompey would undoubtedly criticize as overindulgence. Whereas measuring pleasure through eating and drinking can be exercised privately as a felicitous standard, it is not similarly workable in a Roman sociopolitical context.

The mentions of food and drink throughout the play are too numerous to discuss in full. But one final example makes clear that the many different instances mark a mixed profusion of perspectives, a chief reason for the extensive ambiguity in the words and actions of the characters and in the two major cultures being depicted. Octavius tells Maecenas to "feast the army; we have store to do't, / And they have earned the waste" 
(4.1.16-17). The order would have seemed generous, not just politically astute, had Octavius not used the word "waste"; "waste" suggests that his practicality is hardhearted and that he is mean-spirited, annoyed that he has to give so much for so little and so without a meaning that he respects. In the next scene, Antony issues an order for dinner, saying, "Let's tonight / Be bounteous at our meal” (4.2.10-11). As we have seen, Antony's words characterize a magnanimous gesture, a manifestation of the trait for which he receives the highest praise throughout the play-his bountiful nature. The contrasting perspectives of the two triumvirs prove once again that they cannot easily stall together in the same world. The personal conflict between Antony and Octavius grows out of their differences in temperament and attitude and the values such differences create; moreover, it explains why a universal standard of measurement can never exist. The differing perspectives on food and drink expressed by Cleopatra and Octavius also suggest more broadly a serious, unresolvable cultural conflict. From our vantage point as an audience viewing this clash of perspectives, we are led to believe that there can be no resolution either among people or nations. But because the opposition of perspectives has such a strong hold on us, creating effects of awe and wonder, it does not detract from the renown of the figures involved. Ironically, in creating tension with such engrossing forcefulness, the conflict actually advances it.

From one perspective, the play could be considered very dark in its outlook: ${ }^{23}$ chances for human mutuality disintegrate; everyone but Octavius, whose lack of humane traits we are invited not to admire, is less well off at the end of the play than at the beginning; Antony, Cleopatra, Enobarbus, Pompey, Lepidus, Iras, and Charmian die; sociopolitical wellbeing turns out to be based on egotism and power plays; cultural differences seem impossible to reconcile; and, as the eerie departure of Antony's supposed ancestor and guardian Hercules (4.3) and the presence of the Soothsayer make clear, mysterious forces of fate are at work to change things for the worse. The Soothsayer tells Charmian, "You have seen and proved a fairer former fortune / Than that which is to approach" (1.2.32-33); he reveals to Antony that his "daemon" (2.3.19) or spirit can only be "Noble, courageous, high unmatchable" (2.3.20) when he is not near Caesar, whereas Caesar's spirit, which cannot attain such heights under any circumstances, invariably overpowers and frightens Antony's spirit, just as Caesar's "natural luck" (2.3.26) always allows him to beat his fellow triumvir "gainst the 
odds" (2.3.27). Thus, enough cheerless ingredients seem to be present to enable us to classify the drama a tragedy.

Given this set of circumstances, I return to a subject already touched upon in another context to question once again why audiences and readers nevertheless feel exuberance in experiencing the play. What prompted Coleridge to say with such enthusiastic admiration, "But of all perhaps of Shakespeare's plays the most wonderful is the Antony and Cleopatra?" ${ }^{24}$ As I have indicated, the answer often lies in our amazement and delight at the freshness of the powerfully imaginative language in the play, what Coleridge called "feliciter audax," Shakespeare's "happy valiancy of style." ${ }^{25}$ We are somehow able to separate our reaction to the style from that to the characters and events; consequently, even in the face of the several perils dramatized in the world of the play, we thrill to the stylistic achievements of its creator, much as we do in experiencing the tragedy King Lear. Is Shakespeare implying that our reactions can accommodate this double awareness without making it into a conflict or even wanting to? In addition, we may find ourselves taking joy in the actualized reality of the playwright's feat, because we know this reality to be truer than that of the milieu, fictionalized events, and characters of the play. We do not have to connect any dots to become "wonder-wounded hearers" (Hamlet 4.1.247) of the excellences of Shakespeare's language and syntax. But in experiencing the play, we nevertheless try to, for we are constantly working to interpret and draw conclusions about the actions and behaviors of the characters, often made difficult or impossible because of the innumerable uncertainties and ambiguities. Our pleasure also derives from those scenes in which idealizations are reported (e.g., Caesar's description of Antony's heroics [1.4.57-72] and Enobarbus's description of Cleopatra's superhuman abilities [2.2.238-50]) or seem attainable-at least, for a moment: for example, the scene in which Cleopatra tries to arm Antony before battle, and he shows himself jubilant before his troops (4.4); Antony's return from his unexpected victory (4.8); and, arguably, Cleopatra's death scene (5.2). Still another reason why we are awed and pleased to be so grows out of our fascination with the personal details of the portrayals of Antony and Cleopatra as famed historical persons, portrayals that pique our curiosity and expand our interest in their renown. Ultimately, the play is as authentically cheerful as it can realistically afford to be.

Throughout Antony and Cleopatra, the achievement of pleasure, especially through love, requires measuring up to standards that from 
the Roman perspective inevitably subvert the standards underpinning the sociopolitical concentration on power. It is not clear whether the Romans realize that the danger is not as much in the pleasurable activities themselves as in the mental states that foster them. For Caesar and presumably his entourage, the chief standard of measurement ultimately becomes the acquisition of control and validation of authority through primarily rational, analytical means. But for those who abide by the Egyptian standard, the measure lies in the intensity of a potent sensory and deeply emotional experience. Antony and Cleopatra's flexibility in their gender roles-specifically, their lack of concern for inhabiting prescribed gender behaviors-exemplifies the Egyptian standard operating at its unrestrictive best. The lovers manifest the joyfulness of their love with insouciant abandon, much to the chagrin of Octavius who complains that Antony "is not more manlike / Than Cleopatra, nor the queen of Ptolemy / More womanly than he" (1.4.5-7). Cleopatra later recalls the perfectly natural ease with which she put her "tires and Mantles" (2.5.22) on Antony while she "wore his sword Philippan" (2.5.23). The freedom of play here, much like the lavish spectacles ${ }^{26}$ and the excesses of food and drink, signal some of the most satisfying moments of their relationship.

Act 4, Scene 8 is an ecstatic high point in portraying the joy of Antony and Cleopatra's union, because it is the only time in the play when Antony's feats as a military hero and the mutual pair's intense feelings of love are in perfect euphoric harmony-even if they are able to find such fulfillment only briefly. Antony returns victorious from a battle that neither he nor Cleopatra thought he would win. The triumphant leader enters Alexandria, jubilant at his success in forcing Octavius to retreat: "We have beat him to his camp. Run one before, / And let the queen know of our gests" (4.8.1-2). The reference to Cleopatra by her imperial title and the Latinate word "gests" suggest the heightened tone of the scene, especially in contrast to the informal phrasing of "beat him." Antony continues with his address to his men, making clear that the grand manner of his expression appropriately dignifies the present momentous occasion:

Tomorrow,

Before the sun shall see's, we'll spill the blood That has today escaped. I thank you all, For doughty-handed are you, and have fought Not as you served the cause, but as't had been Each man's like mine; you have shown all Hectors. Enter the city, clip your wives, your friends, 
Tell them your feats, whilst they with joyful tears Wash the congealment from your wounds and kiss The honoured gashes whole.

$(4.8 .2-11)$

Antony's sentiments are extravagant but then so also is his euphoria. Before exhorting his soldiers to return to their wives and friends to revel in the glory of their victory, he promises more victory for the next day, expresses his gratitude to his men, and lavishly praises their performance as if they were all epic heroes ("all Hectors"). Antony's positive metaphorical instructions blend the signs of loving human bonding ("joyful tears" that wash the wound and kisses on the gashes) with battle injuries ("wounds" and "gashes"); clearly, his exuberance for the union of meaningful attachments overrides the gravitas of his sentiment. Moreover, he forcefully dignifies the acts of solace that he advocates: through the addition of "honoured," the formality of the Latinate placement of the adjective "whole" after the noun "gashes," and with the heavy rhythmic emphasis on the final, open-voweled word, "whole."

At this point Cleopatra enters and Antony turns to Scarus, continuing in his ecstatic speech with an imperative:

Give me thy hand;

To this great fairy I'll commend thy acts,

Make her thanks bless thee. [To Cleopatra] O thou day o'th'world,

Chain mine armed neck; leap thou, attire and all,

Through proof of harness to my heart, and there

Ride on the pants triumphing!

$(4.8 .11-16)$

Both the content and the metaphorical density of Antony's words suggest the intensity of his emotional state. In addressing Cleopatra, he glorifies her with a cosmological metaphor that signifies her splendor and stresses her importance to him personally. He then announces what he assumes everyone already knows, that she is a famous, illuminative historical figure, a dazzling presence on the world's stage: "O thou day o'th'world." ${ }^{27}$ The conceit that follows in lines 14-16 describes in vigorous physical terms the full extent to which Cleopatra rules his heart, his most passionate asseveration in the play of the effect of her love on his entire being. Because the metaphor derives from the accoutrements of battle (armor, horse), it underscores the joy Antony feels in the union of 
love and war, the two comfort zones in which he has excelled with heroic dimensions.

The lovers then embrace and, in a grand style commensurate with Antony's, Cleopatra responds, "Lord of lords, / O infinite virtue, com'st thou smiling from / The world's great snare uncaught?" (4.8.16-18). The phrase "The world's great snare" gives us an insight into how Cleopatra considers the world apart from hers; in viewing him as the hunted one, she seems not to understand how much Antony's success as the hunter matters to him. She is simply relieved that he has returned to her "uncaught"; she has yet to acknowledge that there is no escape from the "snare." Throughout the passage, the combination of romantically idealized, aureate diction, heightened, expansive imagery ("this great fairy" [4.8.12] "O thou day o'th'world" [4.8.13]), and epic language (Latinate diction, epithets, imperatives, references to Hector and Phoebus) provide through exalted stylistic grandeur a standard of measure that raises the occasion to unparalleled majestic heights. Antony then tells Cleopatra that they have "beat them to their beds" (4.8.19); the colloquial—even idiomatic—phrase sets off the aureate diction in the scene and makes Antony's jubilation infectious. $\mathrm{He}$ continues, exclaiming elatedly that he has turned time back on itself, and given his awareness throughout the play of passing time, we realize that this victory is the ne plus ultra of joy for him:

What, girl, though grey

Do something mingle with our younger brown, yet ha'we

A brain that nourishes our nerves and can Get goal for goal of youth.

(4.8.19-22)

As this passage demonstrates once again, in combination with Cleopatra's glorification of Antony in addressing him as "infinite virtue" (4.8.17), the final test of both lovers' peerlessness and the ultimate standard of measure in the play, qualifying Antony and Cleopatra as genuinely legendary figures, is their ability to make themselves seem momentarily outside of time and its debilitating effects, godlike figures not subject to the vicissitudes of flux and ill fortune. They have moments in which they embody the qualities described in Hamlet's idealization of Horatio:

A man that Fortune's buffets and rewards Hast ta'en with equal thanks; and blessed are those Whose blood and judgment are so well commeddled 
That they are not a pipe for Fortune's finger

To sound what stop she please.

(Hamlet 3.2.66-70)

In Act 1, Scene 2 and Act 2, Scene 3 of Antony and Cleopatra, we saw that the Soothsayer represents an instrument of the mysterious power of Fate ("Fortune's finger"), an omnipotent power that would seem to control the success or failure of any standard of measure. Fate poses the conflict between Antony's professional and personal lives and the opposition is deepened by the clash in temperament between him and Octavius. The warrior leader seems more overtly aware of the crippling effects of passing time and fortune than does Cleopatra. However, Cleopatra shows just such an awareness when she says that she is "with Phoebus' amorous pinches black / And wrinkled deep in time" (1.5.29-30), reflects on her past (1.2.68-78), and when she mentions her birthday (3.13.189-90). Moreover, at the death of her "man of men" (1.5.75) and with the contemplation of her own suicide, her awareness understandably increases. Given each lover's consciousness of the debilitating effects of time, the two protagonists' highest degree of personal satisfaction and selfhood occurs when they appear to transcend the fixed limitations of time and fortune. The paradoxes that attach to Cleopatra and her behavior and the fact that Antony "continues still a Jove" (4.6.30) even after Hercules, his supposed ancestor and guardian spirit, leaves him (4.3.20-22), dramatize the lovers' moments of godlike superiority as they assume an undaunted indifference to the restlessness and harshness of "Fortune's finger."

Antony turns next to Cleopatra and in contradistinction to the earlier hand-kissing scene with Thidias (3.13), says:

\section{Behold this man [Scarus]}

Commend unto his lips thy favouring hand.-

Kiss it, my warrior.

[Scarus kisses Cleopatra's hand]

As if a god in hate of mankind had

He hath fought today

Destroyed in such a shape.

Cleopatra:

I'll give thee, friend,

An armour all of gold; it was a king's.

Antony: He has deserved it, were it carbuncled

Like holy Phoebus' car.

(4.8.22-29) 
With the standard biblical/epic imperative "Behold" that helped to establish the lofty tone of the opening scene of the play (1.1.13), Antony asks Cleopatra in her imperial role as the ruler of Egypt to honor Scarus by allowing him to kiss her hand. He tells her that Scarus fought as if he were a god, again elevating the victorious battle and its participants by associating the conduct of a soldier with the immortal figure of a god and, by implication, suggesting Antony's extraordinary ability to inspire his men. Matching Antony's hyperbole, Cleopatra promises to honor the soldier with a king's armor of gold. Antony supports her extravagant gift with an additional handsome compliment that again reminds us of his belief that his present activities partake of the milieu of the gods. From Antony's perspective, the world of the gods may ultimately be separate but, at times, exceptional mortal beings can equal it. Thus, this ability, he believes, is a major reason why a human demigod like himself deserves fame.

Antony takes Cleopatra's hand, and they begin a celebratory procession ("jolly march" 4.8.30) through Alexandria. Scene 8 builds to a strong auditory climax stylistically: through the many imperatives; the alternation of sonorous, drawn-out, open vowel sounds and harsh, energetic consonant sounds (plosives); the heavy, emphatic rhythms; the varied syntax; the generalized sentiments; the vivid merging of concrete and abstract language; and the startling juxtaposition of commonplace and striking, unusual details. The scene concludes with a hyperbolic orchestration so powerful that, Antony predicts, it will re-echo from heaven:

\author{
Trumpeters, \\ With brazen din blast you the city's ear; \\ Make mingle with our rattling taborins, \\ That heaven and earth may strike their sounds \\ together, \\ Applauding our approach.
}

$(4.8 .35-39)$

Considering the way this scene comes to a glorious auditory climax, carrying Christopher Marlowe's "high astounding terms" 28 to a level that even he could not imagine, one might well ask if there is anywhere in literature a depiction of more joyous intensity than this scene presents.

As critics have acknowledged and Act 4, Scene 8 demonstrates, Shakespeare imparts a preference for private moments of bonded joy. But once we look at two of the frames of reference he employs to measure the Egyptian and Roman values-mortality and immortality-we understand 
that it is anything but a blind bias. The context of mortality stresses continuance; hence, Cleopatra's desire to size up Octavia as competition rather than simply rejecting Antony. Paradoxically, the fact of change undermines continuance even as it leaves it as the only option. Viewed within the context of immortality, the protagonists, by the greatness of their individualized actions appear to transcend time and are therefore worthy of being immortalized. Cleopatra invokes this context when she describes Antony to Dolabella (5.2.70-99), thereby advancing the legend that immortalizes her lover. From his first appearance in the play, Antony shows his awareness that "Kingdoms are clay" (1.1.37), a fact that Octavius and his Roman compatriots do not factor into their standard of measure and which ultimately makes them seem shallow and small-minded. The irony, of course, is that Antony does not act on his superior wisdom, just as he does not react to the Soothsayer's warnings about the success of Caesar. Cleopatra gains this wisdom as Antony dies and, in committing suicide, acts on it.

Every respondent of the play knows that Shakespeare portrays both Egyptian and Roman values as imperfect. But, always depending upon the perspective one uses to measure success, we sense that Shakespeare finds Egyptian values more meaningfully human and less imperfect. The problem with Egyptian values, however, is that they cannot exist alongside Roman values and the Romans invariably hold the power. Put another way, private lives cannot escape also being a part of the sociopolitical fabric of the state and being subject to its dictates. As we have just seen, Antony and Cleopatra at times outface their mortality through apparent triumphs over the debilitating effects of passing time. She is "infinite variety" (2.2.246) and he is "infinite virtue" (4.8.17). As a result, they become objects of wonder and constant discussion and gain a legendary celebrity status that assures them a permanent place not only in the annals of history but in the popular imagination. The naturalness and consistency with which they are discussed by those within the world of the play sets an example for those outside that world to talk about them and thereby extend their historical renown. As we have already observed, Antony and Cleopatra are not the only ones in the play who evince an awareness of their place in history; Enobarbus's dying words show a similar awareness, one tinged with considerable anguish:

\section{O Antony,}

Nobler than my revolt is infamous

Forgive me in thine own particular, 
But let the world rank me in register

A master-leaver and a fugitive.

$(4.9 .18-22)$

Octavius has a strong awareness of his place in history throughout the play, as he reveals in his desire to keep Antony and Cleopatra alive long enough to parade them before the Roman populace as his captives. Thus, at the end of the play, as throughout, he is characteristically narcissistic about his historical legacy (5.2.354-57). With his usual political canniness and in contradistinction to his earlier pronouncements about the "pair," he nevertheless does promote the legendary status of Antony and Cleopatra-but, at best, as lovers, not as heroic or political figures or as foes. In extending the continuance of their fame, the play gives us another reason for not seeing the outcome of the play as wholly tragic. Given the sociopolitical situation, the lovers have not only reached the highest point in their lives together, but in their deaths persist in triumphing over time, their ultimate symbolic victory. We need now to turn our attention to the portrayals of their deaths and the relation of their suicides to their enduring fame, considered both from a perspective within the world of the play and from Shakespeare's godlike perspective outside that world.

\section{NOTES}

${ }^{1}$ The following is an example of how the two differing cultural perspectives can seem to lead to implications beyond the play. In "Roman World, Egyptian Earth: Cognitive Difference and Empire in Shakespeare's Antony and Cleopatra," Comparative Drama 43, no. 1 (2009): 1-17, Mary Thomas Crane views the cognitive differences between Egyptian and Roman perspectives as an indication of changing attitudes in sixteenth- and seventeenth-century England toward scientific views of the world: "The point that I want to emphasize here is not that Egyptians seem stereotypically 'warm-blooded' and self-indulgent, while Romans are cold, austere, and self-controlled, but that Egyptians in the play reflect an earlier view that environment shapes subjects while the Romans look forward to a Cartesian mind-body split in which self-contained individuals are separate from and gain mastery of their environment" (p. 7). "In Egypt, characters feel themselves to be part of the processes of nature, upon which they depend and which they can't control. Romans, on the other hand, view the world as changed only as a result of human agency" (p. 9). "The play does not attempt to judge which worldview is scientifically correct. It simply marks the passing of one into the other, and registers the perceptual experience of each" (p. 15). Whether one agrees with Crane's conclusions, her statement that the play "registers the perceptual experience of 
each" culture certainly holds true. However we understand "the perceptual experience of each," the perspectives of both cultures will inescapably bear on the characters' standards of measure-those fixed on for themselves as well as those applied to others. For a comprehensive discussion of the different perspectives that critics have toward Rome and Egypt, see Deats, New Critical Essays, pp. 3-6.

${ }^{2}$ See the next note.

${ }^{3}$ In a note to these lines in his edition of Antony and Cleopatra (p. 147), Bevington demonstrates that Shakespeare's fascination with the deceptive nature of perspective is at least ten years old and extends well beyond this play:

Antony is like the type of picture known as a perspective, constructed so as to create an optical illusion whereby dissimilar images are to be perceived from different points of view, as in H5 [Henry V] 5.2.2867: 'you see them perspectively: the cities turned into a maid'; also $R 2$ [Richard II] 2.2.18 ff., and TN [Twelfth Night] 5.1.201.

${ }^{4}$ In contradistinction to his earlier, well-known praise of Cleopatra's exceptional qualities (2.2.200-250), including her "infinite variety," Enobarbus here reacts with psychological realism. In the earlier passage, he was serving a functional role, acting as a spokesperson for the reasons why Cleopatra measures up as a person of fame.

${ }^{5}$ However, although Octavius never lets anything deter him from his quest for power and fame, he does lack some consistency in his reactions to Antony, in part because of the shifts in the kind of character he is - realistic, representational, and functional. Moreover, one has difficulty authenticating the genuineness of his loving feelings toward his sister.

${ }^{6}$ Adelman, The Common Liar, p. 103. Adelman is not the only critic to speak about the disparity between what the words say and what the characters do. Twenty-two years later, in 1995, another critic, gave the subject full treatment: Katharine Eisaman Maus in Inwardness and Theatre in the English Renaissance.

${ }^{7}$ As we have already witnessed, Philo shares this same inconsistency. One could argue that Pompey does as well because, in spite of his initial plan to attack Rome, he expresses his appreciation of a past when the values of the republic were in sway and just revenge was acceptable, seen most clearly in the scene in which he and the three triumvirs negotiate (2.6.1-46).

${ }^{8}$ The phrase "Knowing all measures" could be considered a left-handed compliment, for it suggests the breadth of Antony's life experiences; he has been familiar with "all" measures of fortune, ranging from a "full" measure to "emptiness."

${ }^{9}$ For a discussion of how Shakespeare's interest in modes of perception in Antony and Cleopatra may have been influenced by his familiarity with Christopher Marlowe's Dido, Queen of Carthage, see Robert A. Logan, Shakespeare's Marlowe: The Influence of Christopher Marlowe on Shakespeare's Artistry (Aldershot: Ashgate, 2007), Chapter 7: "Dido, Queen of Carthage as a Precursor to Antony and Cleopatra," especially, pp. 179-84. 
${ }^{10}$ In the Sonnets, for example, we see the contrast when the moral focus dissipates in the face of one that is psychological. For example, in Sonnet 29 ("When, in disgrace with fortune and men's eyes"), the moralistic self-lacerations of the speaker, which lead only to frustration, give way after the first eight lines to a simple, happy psychological resolution. Two other sonnets that play with this duality but in different ways are 129 ("Th' expense of spirit in a waste of shame") and 151 ("Love is too young to know what conscience is").

${ }^{11}$ Two recent critical items that bear on this subject are Tom Rutter, The Cambridge Introduction to Christopher Marlowe (Cambridge: Cambridge University Press, 2012) and Robert A. Logan, "Edward II," in Christopher Marlowe at 450, ed. Sara Munson Deats and Robert A. Logan (Burlington: Ashgate, 2015).

${ }^{12}$ A partial list of incidents would include Gaunt's advice to his son Bolingbroke and to Richard; Duke Theseus's and Egeus's to Hermia; the Friar's to Romeo and the Nurse's to Juliet; Shylock's to Jessica and Lancelot Gobbo; Duke Frederick's to Celia; Brutus's to the conspirators and to Cassius; Laertes's and Polonius's to Ophelia; the advice of Antony's underlings to fight by land rather than by sea; Camillo's and members of the court such as Paulina and Antigonus to Leontes and Polixenes to Florizel. See also the brief discussion in Chapter 2.

${ }^{13}$ For a sense of Plutarch's widespread popularity and influence, see Martha Hale Shackford's Plutarch in Renaissance England with Special Reference to Shakespeare (Wellesley: Wellesley College, 1929), especially pp. 24-40.

${ }^{14}$ See Bevington, Antony and Cleopatra, pp. 5-6, who, in discussing the positive appraisals of Octavius Caesar in history and literature down through the ages, lists a number of writers who dispraised Antony and, secondarily, Cleopatra.

${ }^{15}$ Already discussed in the preceding chapter.

${ }^{16}$ In her discussion of Octavius' behavior in this final scene of the play, Linda Charnes, Notorious Identity, pp. 144-46, suggests that he controls the legendizing of Antony and Cleopatra, restricting their fame in posterity to their roles as "epic lovers" (p. 145) and eliminating their role as political rebels in order to serve his own ends.

${ }^{17}$ See Bevington, Antony and Cleopatra, who in a footnote discusses the difficulties of interpretation created by the uncertain referent of "their" in line 355 of the passage that follows (p. 269). The difficulties do not detract from Octavius's palpable self-interest.

${ }^{18}$ Several critics have written on food and drink in Antony and Cleopatra. To mention only a few: J. Leeds Barroll, "Antony and Pleasure," Journal of English and Germanic Philology 57 (1958): 708-20; Kenneth Muir, "The imagery of Antony and Cleopatra"; Maurice Charney, Roman Plays, pp. 102-7; Peter A. Parolin, "Cloyless Sauce': The Pleasurable Politics of Food in Antony and Cleopatra" in Deats, New Critical Essays, pp. 213-29; Warren Chernaik, The Myth of Rome, pp. 153-54; and Robert Lipscomb, "Caesar's Same-Sex-Food-Sex Dilemma," Early English Studies 2 (2009): 1-13. 
${ }^{19}$ See Pompey's remarks in 2.1.11-27 and Caesar's in 1.4.56-72.

${ }^{20}$ Cleopatra has a less idealized view of food and beverages when she angrily and defiantly tells Proculeius that, in order to commit suicide, she will neither eat nor drink (5.2.48-50).

${ }^{21}$ I mention this interpretation because, as Bevington points out in a footnote, "Possess it, I'll make answer" (2.7.94) could be interpreted as "Drink it off, I'll drink in return." Given Caesar's demeanor and remarks in this scene, I think the joviality of this alternate interpretation less likely.

${ }^{22}$ Related to this particular instance is Enobarbus's remark that Antony “will to his Egyptian dish again” (2.6.123), casting still one additional perspective on Cleopatra as tempting food.

${ }^{23}$ See Barroll, Shakespearean Tragedy, who finds the play a tragedy but different from the tragedy conceived of in the worlds of Hamlet, Othello, and King Lear. Barroll locates the tragedy in Shakespeare's "showing why and how the perceptions of his figures were misperceptions" (p. 279) —in effect, in the misperceptions of themselves and others, Antony and Cleopatra both suffer a "psychic calamity" (p. 288).

${ }^{24}$ Samuel Taylor Coleridge, Coleridge's Writings on Shakespeare, ed. Terence Hawkes (New York: G. P. Putnam's Sons, 1959), p. 246.

${ }^{25}$ Coleridge, Writings on Shakespeare, p. 245.

${ }^{26}$ For example, the lovers' initial entrance (1.1), Cleopatra's first meeting with Antony on the Cydnus (2.2.200-236), Antony piecing "out / Her opulent throne with kingdoms" (1.5.47-48) in Alexandria (3.6.1-20 and 67-77), and Cleopatra's death (5.2.274-308).

${ }^{27}$ Here we have still another use of the expansive phrase "o'th'world" to enhance a protagonist with a sense of epic grandeur. Five lines later, Cleopatra's use of "world" in "the world's great snare" makes clear that she and Antony are on the same wave length in regarding their milieu as epic.

${ }^{28}$ Tamburlaine, Part 1, Prologue, line 5. All quotations from Marlowe's plays are from Christopher Marlowe: The Complete Plays, ed. Mark Thornton Burnett (London: J. M. Dent, 1999). 
Chapter 6

\title{
"A Pair So Famous": Achieving Permanent Renown
}

\author{
Famed be thy tutor, and thy parts of nature \\ Thrice-famed beyond all erudition.
}

Troilus and Cressida 2.3.239-40

In Chapter 4, I alluded to a widening of Antony and Cleopatra's perspectives as they approach their deaths. Both move from an awareness of their fluctuating personal status to a focused, final assertion of their ultimate place in history. Before contemplating suicide, Cleopatra is chiefly concerned with her position as Antony's paramour and, only secondarily, although intertwined, with Rome's derogatory characterization of her; and, once Antony meets Cleopatra, he becomes caught in the crossfire between his position as Roman triumvir and military commander and his love for the Queen. Upon his return to Rome, he appears to make his professional ties as a world leader his primary interest for a time, but his bond with Cleopatra ultimately triumphs as his primary raison d'être. It is now time to treat in detail the changes in the lovers' perspectives at the ends of their lives and how they redound to their fame. We will do well to begin by examining the events immediately before Antony's decision to commit suicide.

In an impulsive moment during the continuing battles with Octavius, Antony misinterprets Cleopatra's collaboration (4.12). More specifically, he believes that she has betrayed him during a second, postActium naval defeat and, although the play does not explain what actually happens during the sea fight, it makes clear that Cleopatra is not responsible for an act of disloyalty: in consternation, she asks Antony, "Why is my lord enraged against his love" (4.12.31) and, later, Diomedes assures him that his suspicions that "she had disposed with Caesar" (4.14.128) "never shall be found" (4.14.127). Whether Antony's rage is in part dis- 
placed, motivated either by anger toward himself or at both himself and Cleopatra for their retreat from the first naval battle at Actium, this misunderstanding occasions some of the most potent invective in the play (4.12.9-49). Once again, even as Shakespeare dramatizes a human flaw in Antony, he makes his audience stand in awe of the triumvir because of his manner of expression: as evidenced in the metaphorical density, the fresh mix of generalized and particularized details, the varied syntax, the strikingly unusual use of words (e.g., "spanieled," "discandy," "becked forth"), and the richly suggestive imagery with which he expresses himself in the following passage:

O sun, thy uprise shall I see no more.

Fortune and Antony part here; even here

Do we shake hands. All come to this? The hearts

That spanieled me at heels, to whom I gave

Their wishes, do discandy, melt their sweets

On blossoming Caesar; and this pine is barked

That overtopped them all. Betrayed I am.

$\mathrm{O}$, this false soul of Egypt! This grave charm,

Whose eye becked forth my wars and called them home,

Whose bosom was my crownet, my chief end,

Like a right gipsy hath at fast and loose

Beguiled me to the very heart of loss.

(4.12.18-29)

This passage is just one example of Antony's unceasing magniloquence.

In the next brief scene (4.13), Cleopatra, seized with fear, makes a fatal mistake. In contrast to the earlier scene in which Charmian tries to instruct her mistress in the proper way to respond as a lover to Antony and Cleopatra rebuffs her (1.3.6-12), here, the Queen listens to Charmian's thoughtless moralizing and follows her dangerous advice, to send word to Antony that she has died. Cleopatra's flight at Actium and the present situation attest that her fears can be all-powerful and can have devastating consequences. They can also produce such erratic behavior as her attempt to draw the dying Antony up to her secure place in her monument rather than coming down to him. To Antony's request at the foot of the monument for some final kisses, she replies, "I dare not, dear-/ Dear my lord, pardon-I dare not, / Lest I be taken" (4.15.21-3). Then, utterly contradicting what she has just said, she expresses her first thoughts of suicide, proclaiming them defiantly and, presumably, in a loud, voice, "Not 
th'imperious show / Of the full-fortuned Caesar ever shall / Be brooched with me" (4.15.23-25). Assuming that there is no textual corruption here and that Antony has not heard Cleopatra's earlier intention to "draw him hither" (4.15.14), we can posit that the Queen's mix of fear, sorrow, and eager desire to take action are responsible for her contradictoriness and confusion. Although the characterization at this point is not completely comprehensible, we are, as usual, invited to try to understand it in psychological rather than moral terms.

Before this death scene, after his initial rage at Cleopatra for her presumed falsity, Antony speaks with philosophical calm, sadness, and utter candor to Eros about mutability, his mortality, and the Queen's betrayal (4.14.1-22). When Mardian enters to tell the triumvir that Cleopatra has died, Antony, immediately overwhelmed with grief, returns to his reflections on mutability and his mortality, speaking wearily with quiet dignity and profound sadness, "Unarm, Eros. The long day's task is done, / And we must sleep" (4.14.35-36). In contrast to the warrior leader's usual hyperbolic manner of speaking, the simple, metaphorical declaration carries a strong emotional charge, making us feel Antony's heartbreak, defeat, and misery all the more because of what it suppresses rather than states outright. As Eros assists in unarming him, Antony feels the full force of his unbearable grief; in his agony, he sadly takes note of the end of his career as a "soldier":

The sevenfold shield of Ajax cannot keep

The battery from my heart. O, cleave, my sides!

Heart, once be stronger than thy continent;

Crack thy frail case! Apace, Eros, apace!

No more a soldier. Bruisèd pieces, go;

You have been nobly borne. ${ }^{1}$

$(4.14 .38-43)$

In a brief stream of imperatives and reflections, Antony gives elevated, even majestic standing to his wrenching sentiments. The formality of the language, the epic frame of reference ("Ajax"), the allusive battle imagery, the personified apostrophes to his "sides," "Heart," and "Bruisèd pieces," and the intensity of his grief-stricken exclamations vividly unite the two most noteworthy achievements of Antony's life-his heroic accomplishments as a military figure and his peerlessness as Cleopatra's loving partner. 
Antony then sends Eros away and soliloquizes, demonstrating, as he often does, that style of expression makes the man even when little else can:

I will o'ertake thee, Cleopatra, and

Weep for my pardon. So it must be, for now

All length is torture; since the torch is out,

Lie down and stray no farther. Now all labour

Mars what it does; yea, very force entangles

Itself with strength. Seal then, and all is done.

Eros!-I come, my queen._Eros!-Stay for me.

Where souls do couch on flowers, we'll hand in hand,

Dido and her Aeneas shall want troops,

And all the haunt be ours.-Come, Eros, Eros!

$(4.14 .44-54)$

Antony begins this speech with a firm commitment to suicide followed by an astonishing reversal, his fervent desire to ask for Cleopatra's "pardon." Even given his customary magnanimity, this latter stated intention is surprising, but it accords with Shakespeare's customary depiction of the omnipotence, depth, and significance of a true bond, the desire for which is, ultimately, a human being's strongest natural impulse. If we try to explain what prompts Antony's drastic proposal, we are left to ask if he has suddenly realized that Cleopatra's death exonerates her from his accusation of betrayal. In his anguished state, does he understand that her death signifies just how deep her love for him has been? The frame of reference of his anger has abruptly been replaced with the more encompassing frame of reference of ultimate reality: mortality. Without Cleopatra, his life holds no meaning.

But, apparently, her death does not preclude a meaningful afterlife, envisioned probably more to buttress his desire for suicide than because he believes in the possibility of an afterlife. In any case, he presents a non-religious fantasy that enhances the renown of both lovers. Specifically, he envisions in Elysium that he and Cleopatra will embody the élan vital that has permeated their most admirable actions in life and be a source of wonder to the "souls" of the other inhabitants who will be happily resting on flowers (a somewhat lighthearted and whimsical notion). Antony fantasizes that, even after death, his and Cleopatra's standard of measure will remain peerless. Shakespeare reinterprets Virgil's tale of the famous classical lovers Dido and Aeneas so that Antony can claim that he and Cleopatra will so 
outstrip their fame that all the spirits of Elysium will be gazing at them in amazement, as presumably the audience of theater goers has been. Clearly, figures of fame require awestruck audiences. Antony has begun the process of myth making that Shakespeare now foregrounds from the moment of the hero's death until the end of the play. In contrasting the renown of the two sets of lovers, Shakespeare is positioning his mutual pair for even greater enduring fame than they have already achieved. Because Virgil's lovers have sustained their renown since the late first century with such evident ease and familiarity, Antony implies that he and Cleopatra, over a slightly longer period, have deservedly surpassed them.

Moreover, if Shakespeare could so drastically refashion Virgil's account of Aeneas and Dido in Elysium, he appears to feel that he has an equally free hand in reworking previous depictions of Antony and Cleopatra. ${ }^{2}$ In addition to turning Virgil's hostile meeting of Dido and Aeneas in Elysium into a scene of happy union, he reverses the epic poet's emphasis on public over private values. That there is so much uncertainty throughout the play, especially the endless ambiguities enveloping the lovers and their actions, may be partially the result of the pre-Shakespearean ambivalences in authorial perspectives toward Dido and Aeneas and the many depictions of them. Shakespeare undoubtedly saw the aesthetic virtues of ambiguity in other accounts before capitalizing on ambiguity as a device for himself. ${ }^{3}$

Just before he tries to convince Eros to plunge a sword into him, Antony ruminates on his achievements as a warrior hero ("I, that with my sword / Quartered the world, and o'er green Neptune's back / With ships made cities" 4.14.57-59) and, implicitly, on his place in the historical record. But since he is speaking only to Eros, whom we know already deeply admires his master, the speech is clearly designed for Shakespeare's audience, not Antony's, another instance in which a major character serves a non-realistic, functional role. The triumvir also makes clear that he and, by extension, Cleopatra, because they act as conquerors of themselves in committing suicide, thereby defeating Caesar (4.14.56-69), are measuring up to their own standard of nobility. Eros's response to Antony's request is also important in further glorifying the heroic leader, especially at this first climactic point in the play. On the one hand, in saying farewell to Antony, the servant's praise is richly suggestive ("worship," "whole world"), once more invoking hyperbole as the normative standard of measure for portraying his leader: "Turn from me then that noble countenance / Wherein the worship of the whole world lies" (4.14.85-86). 
On the other, like Enobarbus, Eros himself gains, as his master says, "A nobleness in record" (4.14.99) in committing suicide rather than witnessing or participating in the suicide of his leader. The commendatory phrase comes generously from the lips of Antony, who reinforces what we already know, that he is particularly conscious of his place in the historical record at this moment. Even before the dying Antony is carried off to Cleopatra, Shakespeare continues to glorify him: seeing that Antony's death is upon him, one guard comments with an expansive cosmological metaphor of grandeur, "The star is fall'n" (4.14.108), and another adds with equal, wide-ranging splendor, "And time is at his period" (4.14.109). With his usual deft employment of ambiguity, Shakespeare makes the connotative, metaphorical significance of these statements clear even if their specific, denotative meaning cannot be taken literally. In light of Antony's serious philosophical contemplation earlier in the scene concerning the dissipating clouds in the heavens and human mutability, the reintroduction of a philosophical context, cosmologically universalized through the suggestiveness of the fallen star and the end of time, emphatically enhances the importance of Antony at this momentous occasion. The echo in the lines from the Book of Revelation only increases the solemnity and weightiness of Antony's demise. ${ }^{4}$ Still another device used to magnify our wonder at the epic image of Antony and at the worldwide consequences of his loss is the sharp contrast with the non-idealized events portrayed in Antony's botching of his suicide and the self-serving opportunism of Dercetus who steals the sword that Antony has used to kill himself. We are called upon to believe that Antony, in spite of human frailties, has measured up to a standard that qualifies him for residence in the pantheon of enduring fame. The problem for the playwright is that, although he can portray Antony as an extraordinary lover, he has fewer opportunities to demonstrate effectively his protagonist's greatness as a hero or a triumvir, because his major accomplishments are largely in the past and because heroic military feats are difficult to depict on a stage, and must therefore be reported rather than presented visually-hence, Shakespeare's many forceful verbal attempts to elevate Antony at his death, as well as before and after.

As Antony is being carried to Cleopatra's monument, the Queen has a heated conversation with Charmian in which she firmly rejects her attendant's advice to "be comforted" (4.15.2) and establishes the standard of measure that she believes must be met in the way one reacts to calamitous events. We know that Cleopatra has had, infallibly, "a prophesying fear" $(4.14 .125)^{5}$ that, upon hearing of her supposed death, Antony would 
kill himself and, agitated and anxious, she now prepares herself for a dire outcome: "All strange and terrible events are welcome, / But comforts we despise. Our size of sorrow, / Proportioned to our cause, must be as great / As that which makes it" (4.15.3-6). Although she does not say so, by this time in the play we know that the "size" of one's response can for Shakespeare be a certain road to fame. At this crucial climactic point the playwright is careful to show that both protagonists are thoroughly selfaware, understanding what it takes to measure up as enduring historical figures. Their fame, although sometimes idealized, is invariably a fictionalized product of the imagination and, as such, devoid of any restrictive boundaries, a principle that Shakespeare clearly demonstrates.

I say "sometimes" because, although the language and syntax Antony and Cleopatra use certainly enhances their splendor and inspires awe, Antony's death scene contains bumptious elements of domestic comedy and a lack of communication between the lovers that call into question how we should perceive the action. Cleopatra's cosmological imagery as she magniloquently addresses Antony creates an awed, aureate tone: "O sun, / Burn the great sphere thou mov'st in; darkling stand / The varying shore o'th'world!" (4.15.10-11). But then, instead of rushing from the monument to greet him below, she immediately busies herself with plans to draw him up to her. Antony seems not to comprehend her intentions, for he pays no attention, but reverts to a topic that we know is heavily on his mind, shouting, "Peace! / Not Caesar's valour hath o'erthrown Antony, / But Antony's hath triumphed on itself" (4.15.14-16). Cleopatra hears the exclamation and agrees; however, when Antony next asks for her kisses, she responds by saying she is afraid to descend because she could be taken captive but then instantly contradicts this expression of fear by promising to commit suicide herself. She next turns to lifting Antony up, and he points out, not without grim irony, that they need to be quick about it before he dies. During the process Cleopatra comments with selfreflective comic irony, "Here's sport indeed!" (4.15.33); and, after wishing that she had the powers of the gods to speed things along, comments with more self-reflective comic irony and the harsh, pragmatic realism of an eminent, universal truth, "Wishers were ever fools" (4.15.38). Having arrived at her level in the monument, Antony accepts his fate but not with grimness; we hear first a bit of lyricism and then a reasonable command, "I am dying, Egypt, dying. / Give me some wine, and let me speak a little" (4.15.43-44). The address to Cleopatra as "Egypt" maintains the elevated tone. But Cleopatra rebuffs his perfectly reasonable request, a 
surprise, given the dire circumstances, contending forcefully, "No, let me speak, and let me rail so high / That the false huswife Fortune break her wheel, / Provoked by my offence" (4.15.45-47). Her irrepressible denial is almost comic in its outrageousness even if the language and content sustain the elevated tone. Antony does not reply, and, apparently unruffled, again shifts abruptly to another topic, advising her that the only person in Caesar's entourage that she can trust is Proculeius. As we soon find out (with more irony), this claim, like the predictions of the underlings about the sea battle at Actium, proves to be wrong. Antony's final speech consists of instructions to Cleopatra on how to configure the legend that he confidently assumes he will become:

... please your thoughts

In feeding them with those my former fortunes,

Wherein I lived the greatest prince o'th'world,

The noblest; and do now not basely die,

Not cowardly put off my helmet to

My countryman-a Roman by a Roman

Valiantly vanquished.

$(4.15 .54-60)$

The phrase "the greatest prince o'th'world, / The noblest" sustains the excessive norm of hyperbole that reminds us of the reason for Antony's fame even as it helps to perpetuate it. Although the exchange between the two lovers in their last scene together lacks continuity in the conversational flow between them, Cleopatra is devastated when Antony dies. Like the two anonymous guards earlier (4.14.105-14), she suggests imaginatively and emotionally that, with the death of Antony, the gold standards of measurement for heroic military achievements and, more generally, for human worthiness have been forever expunged:

\author{
The crown o'th'earth doth melt. My lord! \\ $\mathrm{O}$, withered is the garland of the war; \\ The soldier's pole is fall'n! Young boys and girls \\ Are level now with men; the odds is gone, \\ And there is nothing left remarkable \\ Beneath the visiting moon. \\ $(4.15 .65-70)$
}

The speech sustains the concern with measuring up through its universal and cosmological emphases. In harmonizing previous, similar expres- 
sions, the play evokes in us a purely emotional sense of why Antony's imperishable fame is unimpeachable. The eloquent simplicity and directness of the lines in combination with the intelligence and scope of the tribute also indicate that the speaker is extraordinarily perceptive and loyal, qualities that will soon forever fix themselves as signature traits in Shakespeare's characterization of the Queen's lasting fame.

As soon as she utters these words, Cleopatra faints; upon reviving, she berates herself for not measuring up to her demigod-like status (4.15.78-80). She then asserts that, until Antony died, this world, though separate, was equal to that of the gods (4.15.80-83), but now, "All's but naught" (4.15.83). With absoluteness, this declaration indicates for the second time the reason why she might well commit suicide; but, first, she intends to bury Antony "after the high Roman fashion" (4.15.92). Clearly, in adopting a Roman ritual, her perspective and focus are shifting and, with them, her awareness of values expanding. As Cleopatra's standard of measure shifts, we are reminded of Enobarbus's truism, "I see men's judgements are / A parcel of their fortunes, and things outward / Do draw the inward quality after them / To suffer all alike" (3.13.31-34). Once again this commonplace idea proves true.

Shakespeare could have concluded the play at this point, leading us to believe that Cleopatra would fulfill her purpose as it is stated in the final lines of the scene: "Come, we have no friend / But resolution and the briefest end" (4.15.95-96). But, instead, he continues, giving her the equivalent of an entire act, so that he can dramatically boost the well-established crowning glory of her fame and, more important dramaturgically, intensify the culminating second climax of the play as she actually carries out her suicide. One of his reasons could be because she has become the most interesting character in the play, created so in part by her theatrical personality and unpredictable actions. Another part of his motivation could well be his continuing interest throughout the play in manipulating his audience's perceptions of the often surprising complexities of human behavior, especially as the representatives of these complexities strive to measure up to a final self-image. Up to this point, the play has continually shifted its perspectives on characters and actions, often leaving us stranded in ambivalence and ambiguity. The most imposing contrast takes place when our view of Cleopatra is exalted by Enobarbus's report of her (2.2.200-250) and then three scenes later (2.5) shifts as we experience the displaced anger of the Queen, acting the perfect harridan in her 
treatment of the messenger who brings her the unwelcome news of Antony's marriage. Apart from the contrast between what Enobarbus tells us and what we actually see, complicating our perspectives are the frequent oscillations between perceiving characters realistically and representationally. Whereas Cleopatra's displaced anger in her abusive treatment of the messenger encourages a realistic response, Enobarbus's glorification of the Queen does not. Enobarbus fulfills an artistic function that breaks away from realistic characterization to make her a symbol of uniqueness. ${ }^{6}$ The final act of the play contains both realistic and non-realistic characterizations and events and, yet, even though we are conscious of the artistic means being used to manipulate us, we believe ultimately in the monumentality of the Queen's act of suicide.

Before finally turning his full attention to Cleopatra, Shakespeare provides us with the scene in which Dercetus arrives at Caesar's camp with Antony's sword and reveals that his master is dead. For scholars, the controversy over the scene concerns Octavius's reaction to the news-the degree to which he truly mourns his fellow triumvir and brother-in-law versus the degree to which he disingenuously pretends to feel grief for the benefit of his followers while being more attentive to the politics of the situation than to any true sorrow at Antony's death. Is Octavius genuine or false in his initial reaction to the news? He declares,

\author{
The breaking of so great a thing should make \\ A greater crack. The round world \\ Should have shook lions into civil streets \\ And citizens to their dens. The death of Antony \\ Is not a single doom; in the name lay \\ A moiety of the world.
}

(5.1.14-19)

Does his inflated expression suggest a lack of sincerity, as when, upon Octavia's entry into Rome as a peacemaker, he so ostentatiously greeted her (3.6.43-56)? That, too, was a performance before his political and military followers. Or is he so upset that he truly wishes to honor Antony with his grandiose exclamations and his placing of Antony in a dignified, worldwide context ("The round world" and "A moiety of the world")? It could, conceivably, be a confused combination of the two motives. However we interpret the speech, Dercetus responds to it by illustrating that the legend that Antony insisted should prevail is successfully beginning: 
He is dead, Caesar,

Not by a public minister of justice,

Nor by a hired knife; but that self hand

Which writ his honour in the acts it did

Hath, with the courage which the heart did lend it,

Splitted the heart.

(5.1.19-24)

The simple directness of this statement, abetted by the evidence of a bloody sword, is noticeably effective. Presumably, it causes Caesar either to weep with genuine sorrow or to make a public show of weeping before his audience (5.1.26-28). Agrippa points to the irony of being sad about what they sought with such persistence to make happen (5.1.28-30). Maecenas then expresses a flat truth about Antony, "His taints and honours / Waged equal with him" (5.1.30-31), to which Agrippa counters with "A rarer spirit never / Did steer humanity; but you gods will give us / Some faults to make us men" (5.1.31-33). Agrippa's praise, though so generalized that it covers both of Antony's leadership roles as military commander and triumvir, returns us to the normative hyperbole used to limn Antony at his best. The word "rarer" stresses Antony's uniqueness and the phrase "steer humanity" his imposing function as a supreme role model, not simply in a professional or political way, but primarily as a member of the human race. This is the strongest expression of Antony's greatness in the scene and, noticeably, it is not delivered by Octavius. The remainder of Agrippa's comment clarifies Maecenas's assertion by placing the responsibility for Antony's "faults," but not his greatness, in the hands of the gods. Both Maecenas and Agrippa imply that the gods need to "give" human beings faults to keep them separate and unequal.

Caesar next attempts to justify his hostile pursuit of Antony (5.1.3540) before beginning a speech of soaring declamation. But he stops short when an Egyptian enters, reporting, "But I will tell you at some meeter season. / The business of this man looks out of him; / We'll hear him what he says" (5.1.49-51). Here, we have a perfect illustration of why Caesar is so successful: he never allows anything or anyone to interfere with opportunistic, self-aggrandizing possibilities. The scene continues with the triumvir's hardheaded political maneuvering in his effort to assert control over Cleopatra, and ends with him defensively and egotistically asking his cohorts to go into his tent with him so that he can show, as he defensively states, "How hardly I was drawn into this war, / How calm and gentle I proceeded still / In all my writings" (5.1.74-76). His need to 
justify himself and his absoluteness ("all my writings"), suspiciously disingenuous, only make Antony's "spirit" seem even "rarer." As we have seen, through his assertion of absolute control and his canniness, Caesar succeeds brilliantly, but at the expense of any genuine humanity, a quintessential characteristic that, although Shakespeare's audience is encouraged to value it, Caesar clearly does not. One is reminded of two comments earlier in the play that lead us to a similar understanding of the reasons for Octavius's success: the messenger who reports to Caesar, "Pompey is strong at sea, / And it appears he is beloved of those / That only have feared Caesar" (1.4.36-38) and Pompey's remark that "Caesar gets money where / He loses hearts" (2.1.13-14). As long as the Roman Empire is firmly under his control and his power and fame are increasing, no matter how ruthless he may become, Caesar remains content.

The next scene opens with Cleopatra ruminating on her intention to commit suicide, the same act that she was contemplating when we last saw her. ${ }^{7}$ In a pensive mood, like that of Antony as he was preparing for suicide, she ponders ultimate issues as she attempts to measure up to her new sense of nobility and come to terms with an ultimate system of values; she needs to encourage and brace herself now that she is faced with carrying out her suicide:

My desolation does begin to make A better life. 'Tis paltry to be Caesar;

Not being Fortune, he's but Fortune's knave, A minister of her will. And it is great To do that thing that ends all other deeds, Which shackles accidents and bolts up change, Which sleeps, and never palates more the dung, The beggar's nurse and Caesar's.

$(5.2 .1-7)$

Our perspective on Cleopatra shifts momentarily from viewing her as a person who acts vigorously, decisively and, often, precipitously to a person who carefully reflects and plans according to the thoughtful conclusions she has drawn. She cleverly places Caesar in an indisputably accurate, philosophical context, leveling him with a perception that is eminently satisfying to her: the dungy earth feeds the beggar's nurse and Caesar alike (5.2.8); she echoes Antony's pronouncement earlier that "our dungy earth alike / Feeds beast as man" (1.1.37-38). Both figures clearly perceive the reality behind the fabrication of sociopolitical echelons. 
Proculeius interrupts Cleopatra's ruminations, however, and so the Queen immediately shifts to role-playing in the game of cat and mouse that ensues. His goal is to distract her so that some of Caesar's men can seize her. Cleopatra's insincerity becomes comically ironic, because, when she comments to Proculeius, "If your master / Would have a queen his beggar" (5.2.15-16), we remember the phrase "The beggar's nurse" as an integral part of her expression of contempt for life's vicissitudes and for $\mathrm{Caesar}^{8}$ and, when she commands, "I am his fortune's vassal" (5.2.29), we remember that she has just called Caesar "Fortune's knave." As soon as the Queen is seized and prevented from killing herself with a dagger, Proculeius tries to mollify her, but with unintentional irony only pours salt in the wound when he says, "Cleopatra, / Do not abuse my master's bounty by / Th'undoing of yourself. Let the world see / His nobleness well acted" (5.2.41-44). In addition to the shock that Antony's recommendation to trust Proculeius turns out to be wrong, the latter's use of the words "bounty" and "nobleness" must especially rankle Cleopatra since they have been so often used to characterize Antony's finest qualities. Enraged by Proculeius's deception and her capture, she delivers a potent, inflammatory speech of great imagination and perception, affirming her desire to die:

Sir, I will eat no meat, I'll not drink, sir;

If idle talk will once be necessary

I'll not sleep, neither. This mortal house I'll ruin

Do Caesar what he can. Know, sir, that I

Will not wait pinioned at your master's court,

Nor once be chastised with the sober eye

Of dull Octavia. Shall they hoist me up

And show me to the shouting varletry

Of censuring Rome? Rather a ditch in Egypt

Be gentle grave unto me! Rather on Nilus' mud

Lay me stark nak'd and let the water-flies

Blow me into abhorring! Rather make

My country's high pyramides my gibbet

And hang me up in chains!

$(5.2 .48-61)$

Like Antony when he is furiously angry, Cleopatra expresses herself with wondrous imaginative inventiveness. ${ }^{9}$ Moreover, she characterizes Octavia with a precision that we trust (even smile at) and with traits that are the opposite of Cleopatra's. Her emphatic threefold repetition of "Rather" increases the volume of her rage, so intensifying it that Proculeius 
cannot help but comment on the ugliness of her imagery. This scene admirably demonstrates Shakespeare's ability to create continuity in dialogue through means that are subtle and effective in their emotive potency.

At this point Dolabella appears to relieve Proculeius. The latter maintains his hypocritical stance until Cleopatra pierces his pretense with a brusque message for Caesar: "Say I would die" (5.2.69). Dolabella readily falls under Cleopatra's spell, even if she plays no conscious part in it. His reaction is, of course, a tribute to the magnetic power of her thoroughly seductive charm and foregrounds, in combination with Proculeius's hypocrisy, the contrasting perspectives of Roman political and Egyptian personal interests. After Caesar leaves Cleopatra, Dolabella returns to inform the Queen of the triumvir's intention to have her and her children march before his chariot in his triumphant return to Rome (5.2.196-206); there is no guarantee that Octavius would not then go on to eliminate all of them. Dolabella's bond with Cleopatra offers a momentary bright spot in an otherwise darkening sky. It stresses the play's dominant paradox: that although the fullest personal pleasure derives from human mutuality, the consequences of power politics can easily prevent such pleasure from becoming more than momentary. Cleopatra's suicide can be seen as a valiant attempt to undo the paradox.

Before Dolabella's return to the Queen, Shakespeare orchestrates the much anticipated, first (and only) face-to-face exchange between Octavius and Cleopatra. Both have assumptions about the other that they now suppress in order to continue the game of cat and mouse Cleopatra began with Proculeius. The seething anger of both adversaries is barely below the surface of their statements and a source of semi-comic irony for Shakespeare's audiences. Caesar assures the Queen, "The record of what injuries you did us, / Though written in our flesh, we shall remember / As things but done by chance" (5.2.116-18; my italics). When Caesar announces, "I'll take my leave" (5.2.132), Cleopatra replies with invidious excess, "And may through all the world! 'Tis yours, and we, / Your scutcheons and your signs of conquest, shall / Hang in what place you please" (5.2.133-35). At this point Cleopatra offers Octavius a scroll that supposedly lists all her wealth and calls upon her treasurer, Seleucus, to verify it. Critics are divided on whether Cleopatra has prearranged Seleucus's decision not to verify the inventory or she has in fact kept back enough to purchase what she has made known. ${ }^{10}$ As a consequence, we are left in a fog of ambiguity about her true motives, but an intriguing ambiguity nonetheless. If Cleopatra has cleverly devised this scenario with Seleucus, 
the argument runs, then she is hoping to make Octavius believe that she wishes to live. If not, then this is an instance of Cleopatra attempting to keep her options open, but still a sign to Caesar that she has no inclination to kill herself. Either way, the message to Caesar is clear, but, as the critical controversy attests, the genuineness of Cleopatra's desire to live or die is not. Her explanation to Caesar for holding back her valuables is so patently disingenuous that it is comic (5.2.158-71). In her rage against Seleucus, she uses a telling metaphor: "O slave, of no more trust / Than love that's hired" (5.2.153-54). This expression reminds us that the Romans consistently view her as a whore, but that she sees herself and her love for Antony as something much deeper and finer. The point is made emphatic when she later tells Iras that in Rome "Saucy lictors / Will catch at us like strumpets" (5.2.213-14) and "Some squeaking Cleopatra [will] boy my greatness / I'th'posture of a whore” (5.2.219-20). The play tells us that Cleopatra has had amatory relationships with only three men, Julius Caesar, Pompey, ${ }^{11}$ and Antony, all world leaders. Moreover, she remained loyal throughout the period that Antony was away and married to Octavia. Thus, the consistency of her devotion adumbrates the climactic portrayal of faithful love that concludes the play.

Cleopatra concludes her defense of her treasurer's report by turning to Seleucus with a threat and an insult. Expressing herself with a noticeably clever metaphor and a reminder of the power of her feminine charms, her fresh imagination, and her frequent expressive brilliance, she exclaims emphatically: "Prithee, go hence, / Or I shall show the cinders of my spirits / Through th'ashes of my chance," and adds ruefully: "Wert thou a man, / Thou wouldst have mercy on me" (5.2.171-74). She then shifts to a generalized rationalization to which Caesar does not respond:

Be it known that we, the greatest, are misthought

For things that others do; and when we fall,

We answer others' merits in our name,

Are therefore to be pitied.

$(5.2 .175-78)$

This statement does not apply to the Cleopatra who has just revealed that she herself is responsible for misreporting the treasures that she has withheld. Instead of confronting her with the illogic of her argument, Caesar commends her for her astuteness at deception and with thick hypocrisy promises to be guided by her "counsel," urging her to "Feed and sleep" (5.2.186) — that is, not to kill herself. Promising to remain 
her "friend" (5.2.188), he departs as Cleopatra gushes with full-fledged insincerity and a probable edginess that are comically ironic, "My master, and my lord" (5.2.189). Whereas in this scene Caesar is demanding that Cleopatra measure up to his political standard, she is even more determined to set and follow her own, a standard more personal than political.

Immediately after Caesar departs and without making reference to her treasurer, Cleopatra declares huffily, "He words me, girls, he words me, that I should not / Be noble to myself" (5.2.190-91). The irony in the directness and truth of the statement is made striking by the use of a common noun as a verb and, as such, jolts us back to the reality of the aesthetics of Cleopatra's preparations for suicide. As if to reinforce this perspective, Iras concludes, "Finish, good lady. The bright day is done, / And we are for the dark" (5.2.192-93). We recognize that this sentiment is not a realistic reflection of Iras's psychology so much as an antiphonal response to Antony's statements before his suicide: “The long day's task is done, / and we must sleep" (4.14.35-36) and "for now / All length is torture; since the torch is out, / Lie down and stray no farther" (4.14.45-47). Acting as a functional figure, Iras is being employed to suggest with high regard that, in their mental states before committing suicide, Antony and Cleopatra are completely harmonious and, thus, that the bond between them is admirably secure. Iras's statement dignifies the ambience just as Antony's parallel sentiment did. At this point, Cleopatra sends Charmian off to see about the means for her suicide, and Dolabella returns with information about Caesar's plan for her and her children, a plan that only further confirms her intention to kill herself. She assumes that her children are doomed whatever course of action she takes. ${ }^{12}$ The stage is now set for the final phase of Cleopatra's seemingly circuitous route to suicide.

As if mesmerized by the imagined horror of being paraded as the trophy of the victories of Caesar, Cleopatra turns to Iras and, much as Antony did in attempting to convince Eros to assist in his suicide (4.14.71-77), imagines the following scenario:

Now, Iras, what think's thou?

Thou an Egyptian puppet shall be shown

In Rome as well as I. Mechanic slaves

With greasy aprons, rules, and hammers shall

Uplift us to the view. In their thick breaths,

Rank of gross diet, shall we be enclouded

And forced to drink their vapour.

(5.2.206-12) 
Like Eros, Iras is properly horrified and responds: "The gods forbid!" (5.2.212), but Cleopatra is so absorbed in her imagined scenario that it is almost as if the dialogue is within her head and she is speaking to herself, especially when, in continuing, she says, "Nay, 'tis most certain, Iras," and then confirms the thought with "Nay, that's certain":

Cleopatra: Nay, 'tis most certain, Iras. Saucy lictors

Will catch at us like strumpets, and scald rhymers

Ballad us out o'tune. The quick comedians

Extemporally will stage us and present

Our Alexandrian revels; Antony

Shall be brought drunken forth, and I shall see

Some squeaking Cleopatra boy my greatness

I'th'posture of a whore.

Iras:

O the good gods!

Cleopatra: Nay, that's certain.

$(5.2 .213-21)^{13}$

Here, Cleopatra affirms her "greatness" as an imperial lover and implicitly claims her superiority as an actress skilled in playing before different audiences-whether at court, wandering the streets with Antony, or on the battlefield. She mocks not only Caesar and his intention to humiliate her, but also the impoverished imagination, sensationalized mediocrity, and crassness of the "Saucy lictors," "scald rhymers," "quick comedians," and would-be Roman actors; implicitly, she also scorns the lack of imagination and absence of standards of the Roman populace, the presumed audience of those who pretend to power or creative ability, whom she has earlier characterized as the "shouting varletry"(5.2.55). As she speaks these words to Iras, Cleopatra evidently has a strong sense of how miserably the Romans measure up when imagination is required and how her fame and place in history will be crudely mocked if she is dragged through the streets of Rome as a prized token of Caesar's triumph. Her aesthetic credo and standard of values have never been more defiantly and clearly expressed.

The well-known line in which Cleopatra uses the noun "boy" so strikingly as a verb suddenly shatters our willing suspension of disbelief, breaking our engrossment with the action of the play to bring us into the reality of the early modern playhouse where the audience, watching the play in performance, is made aware of its collective self. ${ }^{14}$ The abrupt and drastic shift of perspective alerts us not only to the effectiveness of such 
a shift but also to the multiplicity of perspectival possibilities within the play, both important bits of knowledge in the dramatist's arsenal of artistic devices. "Squeaking" may be understood as a backhanded compliment to the seventeenth-century youth(s) actually playing the role of Cleopatra. Moreover, in plumping for imaginative excellence, the situation dramatized in the speech establishes a contrast with the superior aesthetic quality of the present drama, thus perhaps revealing a self-congratulatory Shakespeare, a dramatist proud of his work. The speech also tells us something important about the playwright's early modern audiences, indicating that, for them, there are advantages to attending the theater that move beyond the purely recreational. ${ }^{15}$ Even though the theater was criticized in the sixteenth and seventeenth centuries for being a purely recreational venue, it was also a place where political and non-political topics could be freely suggested, considered, and discussed without fear of reprisal for the playgoers. For example, from a sociopolitical vantage point, an audience can readily see that the common people in Julius Caesar and Coriolanus, and the mindless Roman citizenry in Antony and Cleopatra demonstrate how not to behave; we can only speculate about what thoughts of power politics such dramatizations might generate among viewers, but it is certain that within the playhouse playgoers were free to ruminate and even talk about their ideas with fellow playgoers without fearing charges of sedition. In Antony and Cleopatra, Cleopatra imagines that the "shouting varletry" pays no attention to sociopolitical issues; parenthetically, her supposition accurately mirrors Shakespeare's depiction of the Roman masses in Julius Caesar and Coriolanus. By suddenly shifting the frame of reference and making his early modern audiences aware of themselves as an entity listening to subjects relevant to their lives, Shakespeare demonstrates generally that the playhouse is a place useful and liberating in providing issues for discussion among its audience members. If the issues are often sociopolitical in nature, as they are especially in Shakespeare's history plays, the audience may also find a language with which they can discuss such issues. ${ }^{16}$

In the two speeches to Iras, Cleopatra's contempt for "censuring Rome" (5.2.56) appears even more forcefully motivated by aesthetic than sociopolitical interests. Her words are a way of making an early modern audience aware of the crucial role of the imagination in fixing successful aesthetic standards for dramas, beginning with the need for such standards and including the audience's part in fostering and nurturing them. 
Shakespeare implies that, in demanding aesthetically what the Romans do not, his early modern audiences' standard of measure would indubitably be of a high order. If because of Cleopatra's words audiences are able to better understand and appreciate those standards and, thereby, participate in demanding them, they will never have to be subject to "squeaking" youths and a depletion of creative standards. In addition, with regard to the story of Cleopatra's suicide unfolding before the audience, Shakespeare is especially wise in highlighting the possibilities of the imagination at this juncture. In light of their expanded consciousness and fresh appreciation of the imagination, viewers should be better able to enjoy the Queen's creative endeavors in the staging of her suicide. Upon reflection, they may also understand how, in fashioning such an effective death scene, the dramaturgical imagination of the Queen (ultimately Shakespeare's), together with their own imaginative capacity for celebrating her achievement, result in hailing Cleopatra's fame anew and contribute to making it imperishable. ${ }^{17}$

Before we arrive at the climax, we see Cleopatra carefully orchestrating the staging of her final performance, pulling out all the stops to make it stand uncontested as the supreme crowning glory of her famed life: "Show me, my women, like a queen. Go fetch / My best attires. I am again for Cydnus, / To meet Mark Antony" (5.2.226-28); "Bring our crown and all" (5.2.231). Calling for the accoutrements of her regal position as Queen of Egypt and as the most alluring of women, beginning with her "best attires," Cleopatra sets the highest bar possible, matching the exultant spectacle of her death with the equally magnificent spectacle with which she first captivated Antony. At this point, a rustic bumpkin identified as "Clown" enters with a basket containing the fatal asps that she sent for earlier. As he is about to enter, Cleopatra muses to herself with characteristic self-reflective irony, noting "What poor an instrument / May do a noble deed! (5.2.235-36). She continues with an affirmation of her desire for "liberty" through death and her determination to die as a feat of strength, not weakness:

He brings me liberty.

My resolution's placed, and I have nothing

Of woman in me. Now from head to foot I am marble-constant; now the fleeting moon No planet is of mine.

$(5.2 .235-40)$ 
On the one hand, Cleopatra vows to have no more to do with mortality and the afflictions imposed on one through the vicissitudes of flux. On the other, she is once again asserting her ability to transform herself into a demigod, fearlessly measuring up to her most remarkable capabilities, including her "infinite variety."

The Clown is a figure one is accustomed to seeing in Shakespeare's comedies in the decade before he wrote Antony and Cleopatra. Like Dogberry and Verges, he speaks confusedly and with malapropisms. He is good-natured and talkative, oblivious to the manifold ironies his words are creating. In his exchange with Cleopatra, we see how two different perspectives can be brought together to produce comic and serious effects at the same time. We also see a comic rendering of measuring up, as Cleopatra gingerly questions the Clown in an attempt to probe the effectiveness of the asps he has brought her: "Hast thou the pretty worm of Nilus there, / That kills and pains not" (5.2.242-43); "Remember'st thou any that have died on't" (5.2.247); and her final question, "Will it eat me" (5.2.266). The food metaphor, often used by Cleopatra to signify a literal or figurative ingredient of pleasure, assumes a serious ironic cast here underlined by the Clown's exit line, already used earlier when he first attempted to leave: "I wish you joy o'th' worm" (5.2.273).

Having secured the means of accomplishing her suicide, Cleopatra now tends to the last finishing touches before completing the act. With ritualistic solemnity, she issues two short commands to Iras before becoming briefly self-reflective, declaring not only an affirmative determination to die regally but a realistic acknowledgment of what she is leaving behind: "Give me my robe. Put on my crown. I have / Immortal longings in me. Now no more / The juice of Egypt's grape shall moist this lip" (5.2.274-76). Because of its unusual yoking, the witty, perceptive phrase "Immortal longings" lingers in one's memory. It looks forward to her death ("immortal"), her final tribute to the sustained commitment of her bond with Antony ("longings"), and the phrase suggests the erotic intensity, emotional ardor, and deep commitment that have merged to compose her passion for her "man of men." With quick, unsentimental nostalgia the following sentence evokes—with "juice," "grape," "moist," and "lip" - the joyful sensory pleasures that have made her Egyptian life outstanding. Then, paralleling the example of Antony before he committed suicide, she imagines a scenario that impels her to take immediate action: 
Antony call. I see him rouse himself

Methinks I hear

To praise my noble act. I hear him mock

The luck of Caesar, which the gods give men

To excuse their after wrath. Husband, I come!

Now to that name my courage prove my title!

I am fire and air; my other elements

I give to baser life. So, have you done?

Come, then, and take the last warmth of my lips.

Farewell, kind Charmian. Iras, long farewell.

$(5.2 .277-86)$

Cleopatra's words portray a striking and quite splendid multiconsciousness. Shakespeare's imagination, having been stimulated and forcefully quickened by his Pygmalion-like creation, devises a passage in which Cleopatra's myth making becomes an important part of the process of extending and magnifying her fame. Ironically, Shakespeare is unknowingly doing the same for himself: promoting his fame as he promotes hers. Moreover, as Cleopatra goes about myth making, she discovers a way of confidently measuring up to a transcendent standard she may not have known she was capable of but one that cannot help but advance her enduring fame. Cleopatra's final resolution and evident satisfaction present us with an ending to the play that is both uplifting and tragic, leaving us in a final state of mixed responses and some ambiguity.

In her imagined scenario, Cleopatra sees herself motivating Antony to "rouse himself" to praise her noble "act" (5.2.278-79). Her focus on actions once again reminds us of their mutual élan vital, a trait that enables them to excel and produce in their viewers a state of wonderment. That her "act" is "noble" in old-style Roman moral terms adds a new frame of reference, one that idealizes the Queen for fusing through suicide the most contrary and potently opposed cultures of the play. In integrating this opposition, she symbolically finds unity in a contradiction, the action itself a culminating paradox, similar to that which she achieved in making "the holy priests / Bless her when she is riggish" (2.2.249-50). Cleopatra's knowledge of the operations of the gods (5.2.280-81) elevates her status and reminds us that at those times when she best measures up, she can be characterized as a demigod. In calling Antony "Husband," Cleopatra reveals the depth of her bond with him-not without irony, however, since she is not married to him; in surprising us with the appellation, she evokes in us amazement, as she often does, by making the commonplace 
seem extraordinary. We are reminded that she has the capacity to make "defect perfection" (2.2.241) and that "vilest things / Become themselves in her" (2.2.248-49), that her transformative powers make her unique. Cleopatra's following statement ("Now to that name my courage prove my title!") makes us realize that "Husband, I come" is something of a bèot, boasting aloud as further psychological preparation for intensifying her commitment to suicide. Moreover, the statement "Now to that name my courage prove my title!" demonstrates Cleopatra's ability to make use of an authoritatively abstract, moral vocabulary that indelibly and forthrightly proclaims that her newest superior standard of measure has accessed what Antony would recognize as Roman fortitude.

She then asks Iras and Charmian if they have finished dressing her and, as a final farewell gesture, she kisses them. Given Shakespeare's careerlong exaltation of fidelity in human bonding, this extra touch renders Cleopatra particularly admirable at this moment. In another surprise, the kisses are immediately followed by Iras's falling dead at Cleopatra's feet. Iras's astonishing reaction reminds us of the devotion of Enobarbus and Eros to Antony; Charmian's death is about to add one more stunning example. In each case, two devoted followers die for love of their master or mistress. Through the parallel, Shakespeare romantically idealizes such moments, making them stand out in contrast to the stark realpolitik that permeates the world of the play, ever widening the gap between society and the individual, that which is public and that which is private. Cleopatra responds immediately to Charmian's reaction with an ironic self-reflection that, like her earlier line "Here's sport indeed!" (4.15.33), provides some comic irony in the midst of the tragic events: "Have I the aspic in my lips" (5.2.287)? Such remarks indicate her uncanny ability to stand outside the action of which she is a major part for a second or two in order to comment on the irony of the situation. The Queen next indicates her shock at Iras's sudden demise with the question, "Dost fall?" (5.2.287). On the surface, the question seems foolish in its superfluity since Iras has already fallen, but we understand that it is "one of those odd tricks which sorrow shoots / Out of the mind" (4.2.15-16); the question Cleopatra is really asking is, "How dire is the significance of Iras's crumbling to the ground?" She of course already knows the answer, but her emotional reaction has not yet caught up to her thinking reaction. Recovering from her shock at Iras's death and without losing her presence of mind or her unerring, instinctive sense of theatricality, she cleverly exploits the occasion of 
her attendant's death to further her myth making, her chief means of firming up her resolution:

If thou and nature can so gently part,

The stroke of death is as a lover's pinch,

Which hurts, and is desired. Dost thou lie still?

If thus thou vanishest, thou tell'st the world

It is not worth leave-taking.

$(5.2 .288-92)$

Cleopatra's words remind us of the fear she has had to overcome in taking her own life. She then replicates a pre-Christian version (anachronistically?) of the traditional Christian attitude of contemptus mundi, the familiar ritual statement customarily proclaimed at the time of one's death. Charmian interrupts her reverie to remind us antiphonally of Antony's description of deliquescence (4.14.1-14) and, therefore, his presumed compatibility with the motives for Cleopatra's suicide: "Dissolve, thick cloud, and rain, that I may say / The gods themselves do weep!” (5.2.29394). Cleopatra continues myth making, imagining that her supposed envy impels her to measure up: "This proves me base. / If she first meet the curlèd Antony, / He'll make demand of her, and spend that kiss / Which is my heaven to have" (5.2.294-97). With these words, Shakespeare blends the moral and aesthetic perspectives ("base" and "curlèd"), but, in concluding with a focus on the kiss, asserts the value of the latter over the former.

At this point, Cleopatra addresses with anthropomorphic irony one of the asps, "Come, thou mortal wretch" (5.2.297), and, as she applies it to her breast, relays her fatal instructions:

With thy sharp teeth this knot intrinsicate Of life at once untie. Poor venomous fool, Be angry, and dispatch. $\mathrm{O}$, couldst thou speak, That I might hear thee call great Caesar ass Unpolicied!

(5.2.298-302)

Shakespeare here presents three different perspectives in three sentences, clearly demonstrating Cleopatra's "infinite variety." The first addresses the asp with the Queen's ironic awareness that, although it is itself mortal, it governs her mortality. The sentence also contains an unforgettable metaphor of death in the form of the bite of an asp untying the "knot intrinsicate" of life. As so often happens in this play, the fresh, imaginative 
form of expression outstrips the literal meaning, once again causing the audience to respond with awe or wonder, here especially with the suggestive Shakespearean coinage "intrinsicate." Moreover, the word intensifies Cleopatra's imaginative and intellectual abilities and her sense of control. The phrase as a whole suggests the depth of her understanding of mortality. The next sentence, a second perspective-once again tinged with irony-is cajoling and tender in its affectionate imperative, revealing her ability to understand the blind workings of nature's creatures with compassion. The final sentence and third perspective contains a smack of satisfaction that the Queen has so neatly undermined Caesar's conniving machinations. Her mockery encompasses not only the man but also the political plan he has adopted for her and her children; it also reaffirms her contempt for policy, the foundation of Caesar's behavior as Shakespeare portrays it. In effect, Cleopatra sabotages, even if only briefly, Octavius's strongest motivational means to fame as she measures up to her greatest ever, self-styled performance.

Charmian interrupts Cleopatra with an emphatic cosmological image, "O eastern star!" (5.2.302). Her words are meant not only to enhance Cleopatra's act but to show that she herself has been ennobled by it. Her exclamation mirrors the words of the guard at Antony's suicide: "The star is fall'n" (4.14.108). This antiphonal statement suggests ritualistically once again that, in committing suicide, the lovers achieve absolute harmony and perform monumental actions-both in their own eyes and in those of others. Cleopatra responds to Charmian, gently imploring her silence: "Peace, peace! / Dost thou not see my baby at my breast, / That sucks the nurse asleep?" (5.2.302-4). We have been aware that Cleopatra is a mother throughout the play, but we have not seen her motherly tenderness before now. Shakespeare offers one more dimension of her infinite variety, but because of the ironies of the asp as the baby and Cleopatra as the nurse giving suck, he forgoes sentimentality for a richer, deeper emotional response. Once again, Cleopatra makes a commonplace situation seem extraordinary. Also, typically, Cleopatra in her myth making focuses the dramatic situation on a private bonding that assumes primary importance. Viewing the tableau, Charmian becomes emotionally overwrought-so much so that she can only speak softly in fragmented, griefstricken imperatives: “O, break! O, break!” (5.2.304). Already drifting off, Cleopatra then applies a second asp to her breast and with her final words suggests in her serenity, composure, and unwillingness to stay "In this wild world" (5.2.308) that she has successfully measured up to her 
own immediate personal standards. Shakespeare has thereby provided one concluding element in the memorable act that has so securely solidified her enduring fame. Charmian's completion of Cleopatra's thought signifies her harmony with her mistress's psychology, as well as her admiration and devotion. Earlier, in the second scene of Act 1, Charmian fantasized frivolously about imitating Cleopatra; in applying the asp to herself, she at last does so meaningfully, in a final, supreme act of loyalty. We have seen Antony's extraordinary ability to inspire his soldiers; with the deaths of Iras and Charmian, we now see the same characteristic in Cleopatra.

Before killing herself, Charmian pays tribute to Cleopatra's most incomparable act of measuring up:

Now boast thee, Death, in thy possession lies

A lass unparalleled. Downy windows, close;

And golden Phoebus never be beheld

Of eyes again so royal!

$(5.2 .309-12)$

The phrase "lass unparalleled" provides moving praise, combining two common words in an uncommon yoking, and the apostrophe to "Death" made resplendent with the suggestive, aureate mention of "golden Phoebus" in the following sentence. As if to add the ultimate touch of splendor and perfection to Cleopatra's performance, Charmian notices that the Queen's “crown's awry" (5.2.312), vowing, "I'll mend it, and then play" (5.2.313). The ironic euphemism "play" keeps the focus squarely on the aesthetics of pleasure that stand at the center of Egyptian culture.

The guard who enters next asks the dying servant in a sharp, accusatory tone, "What work is here, Charmian? Is this well done?" (5.2.319). Her answer bespeaks her pride in Cleopatra's regal aesthetic triumph, "It is well done, and fitting for a princess / Descended of so many royal kings" (5.2.320-21). Although the question derives from Plutarch's account, the focus here is on stressing how well Cleopatra and Charmian have measured up through their suicides by taking ultimate control over the passage of time-as we know, a concern of utmost importance throughout the play. With the appearance of Caesar, the focus remains on measuring up. The triumvir looks at Cleopatra and comments, "she looks like sleep, / As she would catch another Antony / In her strong toil of grace" (5.2.34042). The phrase "strong toil of grace" is suggestive rather than definitive but limited to amorousness since it pertains only to Cleopatra's ability to entice another Antony. Caesar concludes the play with an ambiguous 
tribute to the lovers and an unambiguous egotistical tribute to himself for meeting his own standards so well in bringing them to this pass.

Shakespeare has not only sustained his strong dramatic focus on measuring up in concluding the final climax of the play but has idealized the standard of measure through his portrayal of the Queen's royal theatrical spectacle. In staging and performing her final act of suicide, Cleopatra has measured up specifically to a new paradoxical combination of the noble Roman wife and the majestic, freewheeling Egyptian queen, a mingling of the ideal best of two conflicting cultures. With a manner suggestive of the godlike control of the playwright himself and an unrestrained exercise of her most exalted imaginative powers, she promotes a famed immortality more real than anything she dreamed of at the beginning of the play. Charmian's comments suggest the royal style with which her mistress conducted herself in carrying out her suicide, and Caesar offers a tribute to her remarkable, enduring ability to enthrall.

It is evident that, for Shakespeare, dramatizing history in Antony and Cleopatra is not primarily a matter of portraying political and military strategies, negotiations, and clashes during peace or war. Instead, history consists of depictions of conflicts of personalities, juxtaposing varying differences in perspective, whether the motivation behind or the origin of a particular stance is clear. The scenes in which Antony returns to Rome (2.2) and the triumvirs' first meeting with Pompey (2.6) exemplify Shakespeare's single-minded, wholly dramaturgical perspective. Clearly, history per se is not as central to Shakespeare's portrayal of this important historical period as his aesthetic appreciation of perspectival variations in human behavior and the possibilities they offer for creating situations of engaging drama.

Ultimately, the final act of the play is a realization of Shakespeare's own artistic standards of measure, especially with regard to the effectiveness of multiple perspectives. Cleopatra's perspectives are never more varied, complex, and triumphantly blended than when she decides to commit suicide. That Shakespeare made the effort to conclude the play with Cleopatra's suicide leads us to believe that he relished the idea of making theater exciting through the variety employed in stimulating an audience's multiconsciousness. The final act of the play suggests that for him such a response may be a dramaturgical rule of thumb and is best created through the portrayal of unexpected and inexplicable changes in human behavior. These changes encompass the ups and downs of variable and clashing perspectives, as well as shifts in considerations of time and fortune, and are 
inevitably linked to dramatizing shifting combinations of standards of measure and the ongoing process of extending imperishable fame.

\section{NOTES}

${ }^{1}$ There is a psychological parallel to be drawn with a scene in Othello: when Othello comes to believe that Desdemona has betrayed him (and is, therefore, dead to him), he also says farewell to his profession (3.3.347-57).

${ }^{2}$ For a discussion of the changes from Horace and Virgil, see Chernaik, Myth of Rome, pp. 135-40, and for discussions of the changes from Virgil and possible influences in the story of Dido and Aeneas from Chaucer and Marlowe, see Adelman, The Common Liar, pp. 68-78. In Chapter 3 ("Errant Eros: Transgressions of Sex, Gender, and Desire in Dido, Queene of Carthage") of Sex, Gender, and Desire in the Plays of Christopher Marlowe (Newark: University of Delaware Press, 1997), pp. 89-124, Sara Munson Deats has also discussed deviations from Virgil in Marlowe's treatment of the story of Dido and Aeneas.

${ }^{3}$ Shakespeare had certainly viewed the success of such ambiguity in Marlowe's dramas. See the discussions of the latter's ambiguities in Sara Munson Deats: "Masquerade or Metamorphosis: The Performance of Gender in Edward II" in Sex, Gender, and Desire, pp. 162-201, and "Marlowe's Interrogative Drama" in Marlowe's Empery: Expanding His Critical Contexts, ed. Sara Munson Deats and Robert A. Logan (Newark: University of Delaware Press, 2002), pp. 107-30 but especially pp. 120-24. See also Logan, "Edward II, Richard II, the Will to Play, and an Aesthetic of Ambiguity" in Shakespeare's Marlowe, pp. 83-116, and "Edward II" in Christopher Marlowe at 450, ed Sara Munson Deats and Robert A. Logan, (Burlington: Ashgate, 2015).

${ }^{4}$ See Bevington, Antony and Cleopatra, p. 235 n. 108, who cites and quotes from the apocalyptic biblical phrases in the Book of Revelation.

${ }^{5}$ Throughout Shakespeare's plays, those who foresee and have intuitions about people and events are always correct. For example, in Richard II, Gaunt's prognostication (2.1.31-39) and Richard's (5.1.55-68); in Romeo and Juliet, the hunches of both Romeo (1.4.106-11) and Juliet (3.5.54-57); in Julius Caesar, the Soothsayer (1.2.14-25); Hamlet's words to the accusations of the Ghost, "O my prophetic soul" (1.5.41); Desdemona's intuitive sense of her impending death (4.4.23-33); and the Soothsayer in Antony and Cleopatra (1.2.6-52 and 2.3.10-29) as well as the "prophesying fear" (4.14.125) of the Queen herself. This involuntary sense is one indication that the playwright believes in the superiority of one's non-rational faculties.

${ }^{6}$ For a fuller treatment of Shakespeare's use of characterizations that change from being realistic, representational, or functional, see Chapter 1 of this study and my essay "'High events as these': Sources, Influences, and the Artistry of Antony and Cleopatra" in Deats, New Critical Essays, pp. 153-74. 
${ }^{7}$ For a lengthy analysis of this scene, which focuses on the opposition of public and private values, see Julian Markels, Pillar of the World, pp. 140-51.

${ }^{8}$ Cleopatra uses the word "beggars" a few lines later (5.2.47) to suggest a group easily susceptible to death:

\section{Where art thou, Death?}

Come hither, come! Come, come, and take a queen

Worth many babes and beggars.

$(5.2 .45-47)$

Thus, the irony continues, but here it is deadly serious.

9 This tendency to speak with dense, vivid metaphors is of course generally true of Shakespeare's characters when they become emotionally wrought up.

${ }^{10}$ Plutarch's account is of little help in clarifying Shakespeare's intentions. In Plutarch, Cleopatra has before this point indicated to Caesar that she wishes to live. Seleucus "by chaunce" (Spevak, $A$ New Variorum, p. 454) happens to be standing by when Cleopatra gives Caesar "a breefe and memoriall of all the readie money \& treasure she had" (p. 454). In order to ingratiate himself with Caesar, he comes forward to disprove Cleopatra; she then flies into a rage and attacks him and Caesar bursts into laughter.

${ }^{11}$ As scholars have noted, Shakespeare has mistaken Pompey the Great, the father of the Pompey who appears in the play, for the latter's older brother. The mistake nevertheless shows Shakespeare's intention to credit Cleopatra with establishing links solely with renowned men. children.

${ }_{12}$ Although, according to history, Octavia took in and raised Cleopatra's

${ }^{13}$ For commentary on how this speech fits into the play as a whole, see Markels, Pillar of the World, pp. 3-8. Markels takes with a validity that I do not accept the Roman characterization of Cleopatra as a "whore."

${ }^{14}$ A similar, though less obvious reminder of the reality of the performance in the playhouse occurs in Richard II when York describes Bolingbroke's entrance into London as king, followed by Richard:

As in a theater the eyes of men,

After a well-graced actor leaves the stage,

Are idly bent on him that enters next,

Thinking his prattle to be tedious,

Even so, or with much more contempt, men's eyes

Did scowl on gentle Richard.

$(5.2 .23-28)$

${ }^{15}$ In making this point, I am indebted to a statement by Jeffrey S. Doty in his essay "Shakespeare's Richard II, 'Popularity,' and the Early Modern Public Sphere," Shakespeare Quarterly 61, no. 2 (2010): 182-205. Doty is expanding a point made by Paul Yachnin: "Yachnin argues that the theater has been long misrecognized by 
contemporaries and scholars as merely a recreational space when in fact it gave its makers and partakers very serious opportunities for self- and collective fashioning" (pp. 187-88).

${ }^{16}$ Doty's article discusses the way in which Richard II raises sociopolitical issues for discussions and provides a language for such discussions. He defines his purpose in the essay, saying, "I argue that Richard II reflects late Elizabethan concerns about an emergent public sphere, of which the theater was an important part" (p. 182).

${ }^{17}$ Shakespeare's lifelong concern with the imagination-its function, uses, and abuses-is of course not new to Antony and Cleopatra. I have already discussed Theseus's speech at the beginning of Act 5 of $A$ Midsummer Night's Dream and the prologues (choruses) to each act of Henry $V$ as two well-known examples that precede Antony and Cleopatra and, as I have discussed in Shakespeare's Marlowe (see especially pp. 214-19), The Tempest continues the preoccupation. 



\title{
Shakespeare’s Imperishable Fame
}

\author{
graves at my command \\ Have waked their sleepers, oped, and let 'em forth \\ By my so potent art.
}

The Tempest 5.1.48-50

By the twentieth century, Shakespeare was ensconced as one of the five most internationally well-known, respected persons of fame of all time. ${ }^{1}$ Also during that century, people who had insufficient knowledge of the texts of the plays and poetry began increasingly to respond to Shakespeare as if he were a celebrity; and, now in the twenty-first century, he reappears in that guise with even greater regularity, again often due to those who have little understanding of the playwright's works and how they constitute the basis for giving true, enduring authenticity to his fame. ${ }^{2}$ The following discussion begins with an explanation of Shakespeare's present renowned status, including its contemporary sources. It continues with a description of the historical origins of his acclaim before taking a brief look at its progress down through the centuries. The chapter concludes with an exploration of the similarities and differences between paradigms of fame as Shakespeare portrays them in Antony and Cleopatra and our current paradigms of fame in venerating Shakespeare. Much of what follows will be familiar information to scholars and students of Shakespeare, but my hope is that, in being directed toward an understanding of the ongoing advancement of Shakespeare's fame, it will serve a purpose that has hitherto been given little attention.

As everyone knows, Shakespeare first became recognized and celebrated because of the staging of his plays. But he became famous because his playtexts were put into print and because, down through the centuries, they were continually transferred onto the stage (often as adaptations), 
read, studied, and written about. It was the publication of his poetry (especially the Sonnets, ${ }^{3}$ Venus and Adonis, and The Rape of Lucrece) that established his initial claim to serious literary merit, as he seems to have intended it should. Today, even though his poetry has not achieved the widespread popularity of his plays, it has certainly added support to his eminence, especially among students and scholars. The texts of both the plays and the poetry became assured of permanent fame when, in the nineteenth century in England and America, they were made a fixed part of school curricula on all levels; concomitantly, they became the subject of increasingly widespread international publications resulting primarily from scholarly investigations and critical interpretations but also from articles in magazines and newspapers. Since that time, schools throughout the world have incorporated the works of the Bard into their educational programs. Exposing students to Shakespeare has supplied support for the rise of the Shakespeare industry in which scholars and critics, many of whom are also teachers, write and hold conferences to discuss the works; directors produce plays, films, and radio and television versions of the dramatic texts, including adaptations, spin-offs, and audio recordings; composers of music, opera, and dance incorporate Shakespeare's output into a variety of configurations; publishers provide us with a constant flow of new editions and commentary on the works; and the internet gives us endless opportunities for information about every aspect of Shakespeare: the man, his works, the productions of his plays, and on both the internet and television an overwhelming number of advertisements for everything from coffee mugs to coloring books to figurines to toothpaste to an unassuming lime-green paint. There are many incalculable reasons why people of all sorts find meaning in interacting in some way with Shakespeare and his works, all based on the monumentality of his fame. We have arrived at the point where in the current popular imagination Shakespeare reigns as a figure of rare eminence simply because he has become renowned as such. A major consequence of the massive interest in the Bard is that it has turned him and his works into moneymaking commodities, commodities that simultaneously reflect and promote Shakespeare's reputation. Apart from the limitless number of tchotchkes somehow linked to Shakespeare and sold in stores, there is an immeasurable assortment of items bearing his name in theater gift shops, a constant flow of opportunities to see stage and film productions of his plays (often with well-known stars), and a seemingly endless supply of books, CDs, DVDs, and audio recordings all having to do with the man and his works. 
Today, stage, movie, and television performances of Shakespeare's plays, as well as viewings on the internet, seldom occur without some modernized form of contrivance to offset the difficulties of the language and, ultimately, to invite the participation of the widest possible range of audience members. New, usually updated settings, additions to the content, severe cuts, and elaborate staging account for many of the changes. Consequently, the audiences for these productions vary from those who understand the original texts in a variety of ways to those who have no knowledge of them at all. The latter instance explains why Shakespeare is often regarded as a celebrity rather than as a writer truly deserving famein effect, a signifier whose reputation begins and ends with his role as a signifier without any clear signification. Even though the many contemporary productions of his plays often appear unsuccessful to critics, the flow of new stage, screen, and television versions is constant. Perhaps a good part of the reason for this is that schools frequently perform the plays, and classes in which Shakespeare is studied more and more integrate a performance component into their courses, thereby preparing and encouraging students to view Shakespeare's plays later in life, even when the connection is rooted in little more than a vague nostalgia; and, to be sure, professional stagings have met with success partly because productions in schools on all levels have planted the seeds. Thus, both professional and non-professional performances of the plays, including academic performances, have only enhanced the reputation of Shakespeare's fame.

Some of Shakespeare's works have achieved an independent fame of their own. A Midsummer Night's Dream, Romeo and Juliet, The Merchant of Venice, Hamlet, and Macbeth are probably the most obvious examples. A Midsummer Night's Dream seems to have achieved considerable popularity as the most accessible play to students being initiated into Shakespeare's works and is widely staged. The basic situation of the teenage lovers in Romeo and Juliet is as familiar as Shylock, Macbeth (and even Lady Macbeth), and Hamlet, the melancholy Dane, whose line, "To be, or not to be-that is the question," is quoted constantly. It almost goes without saying that, even if the reputation of these plays is independent of their author's fame, their constant reappearance implies the greatness of the writer responsible for composing them and, of course, only adds to his prominence.

In addition to the fame of individual works, there are characters in Shakespeare's plays that have achieved a renown that makes them household words. ${ }^{4}$ Some of them had already achieved acclaim or notoriety 
before Shakespeare fastened onto them, because they were prominent historical figures-Antony, Cleopatra, Julius Caesar, and the many personages from English history that Shakespeare portrays are all examples. But characters without historical provenance such as Hamlet, Macbeth, Shylock, Romeo, and Juliet are equally famous. Like the most familiar plays, the renown of these figures, although distinct from Shakespeare's fame, nevertheless signifies and contributes to his even greater stature as their creator.

Without the studious pursuits of students and scholars, Shakespeare's texts would no longer have a direct connection with his iconic status. They best provide a genuine understanding of his greatness as a writer and, consequently, the most readily verifiable reasons for his widespread fame. But they only partly constitute our contemporary exaltation of the man as the world's greatest playwright and poet. Indeed, as I just indicated, only a slight familiarity with such plays as Romeo and Juliet and Hamlet or with the Sonnets can still suggest to most people the glorified reputation of their author. ${ }^{5}$ That is, when the works are not valued for their characters, plots, content, form, or style, their very titles nevertheless can act as signifiers of the celebrity status of their progenitor. They do so because, in the twenty-first century for us universally, Shakespeare's name itself has come to stand for a culture hero of outstanding expressive gifts and, as a result of our myth making, an unparalleled creative genius of exemplary moral principles. In fact, because his stories and sentiments, not to mention his person, have continued to be of transhistorical interest, however they have been represented and misrepresented, his present fame is not only selfsustaining but self-generating, always begetting anew his imperishability.

In his 2004, popular biography of Shakespeare, Will in the World: How Shakespeare Became Shakespeare, Stephen Greenblatt ${ }^{6}$ blends fact and fiction, perpetuating the myth of the writer from Stratford even as he reconfigures it. In effect, Greenblatt transforms Shakespeare into the iconic figure he would like him to have been. This account is not different from what many people have done, beginning in the seventeenth century but especially since the nineteenth century and not only in England and the United States. Nor is it different from what Shakespeare himself does in Antony and Cleopatra as he adds substance to historical accounts with details about the behavior of his protagonists and their subordinates. Because myth making is a common ingredient in the process of creating imperishable fame, we turn Shakespeare into the monumental figure we wish to believe he was: a man for all seasons whose works, for those in 
the know, portray with extraordinary acuteness current psychological behaviors and sociopolitical situations. For those not in the know, he is, nevertheless, a symbol of artistic excellence and, by extension, moral probity. ${ }^{7}$ In sum, he is a figure that both informed and uninformed people are able to make into their own mythographic, high-minded image. When Shakespeare was first reintroduced into the culture of the United States in the nineteenth century, both the upper and lower reaches of society embraced him. But for us in the twenty-first century he has become, for the most part, a highbrow celebrity-even if, paradoxically, dramatizations of his plays and spin-offs have tried to encompass ordinary and even lowbrow tastes.

Ironically, movies have helped to create his highbrow status. I say "ironically" because their intention has been the opposite, to popularize Shakespeare. Shakespeare's plays have been the basis of films since the late nineteenth century, shortly after the beginning of the silent film era. ${ }^{8}$ One of the most significant effects of the films has been to secure for Shakespeare an international reputation of incomparable distinction. Beginning with the first decade of the twentieth century, filmmakers from across Europe, Asia, Africa, and the Americas have helped to ensure that Shakespeare's fame extends to every corner of the planet; this trend was set in motion during the first three decades of the twentieth century when more than four hundred silent films based on Shakespeare's works were produced. Once "talkies" began, the character of Shakespeare films changed; instead of finding visual equivalents for the language, the language became an essential part of the films. However, because Shakespeare's language is the most intimidating element of his works for most people, directors now attempt to find ways to diminish its prominence, beginning with drastic textual cuts.

During the twentieth century, directors became recognized as the primary creators and artistic producers of films. Auteurs all, the six most well-known and influential directors of Shakespeare films are Grigori Kozintsev (1905-73); Laurence Olivier (1907-89); Akira Kurosawa (1910-98); Orson Welles (1915-85); Franco Zeffirelli (b. 1923); and Kenneth Branagh (b. 1960). All except Welles produced versions of Hamlet and all concentrated primarily on tragedies, although Branagh less so than the others. ${ }^{9}$

Laurence Olivier began the parade of well-known Shakespeare films with his versions of three of Shakespeare's plays, Henry V (1944), Hamlet (1948), and Richard III (1955); not only did Olivier act in his own 
Shakespearean films but he acted in those of other directors (As You Like It, Othello, The Merchant of Venice, King Lear) and of course was also wellknown for his many stage versions of Shakespeare's plays. Roughly contemporary with Olivier's film work, Orson Welles endeavored an imaginative recreation of three of Shakespeare's tragedies and a mélange of the plays that focused on Falstaff entitled Chimes at Midnight. Kurasawa was also making his appearance at about this time, internationalizing the taste for Shakespeare by incorporating it into his own Japanese cultural traditions. From another part of the globe, Kozintsev echoed Kurasawa's desire to adapt Shakespeare to the traditions of a non-English speaking culture. Then came Franco Zeffirelli with his Taming of the Shrew (1966), Romeo and Juliet (1968), Hamlet (1990), and Verdi's operatic version of Othello (Otello, 1986). Zeffirelli was responsible for popularizing Shakespeare through films, as no one had yet done, making his versions commercial successes. Currently, Kenneth Branagh has established as strong a reputation as either Olivier or Zeffirelli for transforming Shakespeare's texts into films. Like Olivier, Branagh has, in the first four of his six movies and in The Winter's Tale, a cinematic rendering of a live performance, taken on the double roles of director and actor: Henry V (1989), Much Ado About Nothing (1993), Hamlet (1996), Love's Labour's Lost (2000), As You Like It (2007), and The Winter's Tale (2015); he also acted the role of Iago in a version of Othello (1995) he did not direct. Like Olivier, Branagh has performed in several of Shakespeare's plays on the stage: among them, Richard III, Romeo and Juliet, As You Like It, Henry V, Hamlet, King Lear, and Macbeth. Moreover, like Zeffirelli, he has attempted to popularize the plays. Clearly, Branagh has absorbed the tendencies of his predecessors, undisguisedly making use of his knowledge of other filmmakers, but also employing well-known actors to help popularize his films. In addition, like Olivier, he has taken advantage of his stage experiences with Shakespeare's dramas, ${ }^{10}$ and he has produced more films and established a broader range of plays and, hence, films than any of the directors who preceded him. Moreover, he was a major participant in the explosion of Shakespeare films in the 1990s, the decade of the twentieth century that was the most prolific.

A multitude of other Shakespearean films by various directors has found screen time, beginning with the spate of silent films already mentioned. Also, since the last quarter of the twentieth century, numerous adaptations such as $O(2000)$, based on Othello, and wild cards such as the Baz Luhrmann's Romeo and Juliet (1996), meant to make the play 
accessible to young people familiar with MTV, have contributed to creating Shakespeare's enduring fame even as they cashed in on it. The upshot is that, in abandoning as much as a third of the playwright's text, filmic dramatizations of his plays and movie adaptations have not only attempted to reach a widespread audience but have helped to obscure the most essential reasons for the justness of Shakespeare's fame. Instead, they have provided translations of a sort suggesting that the actual texts are written in a foreign language and therefore relegated to the province of the learned.

Television versions of the plays, as well as televised discussions of the Shakespeare authorship question, have been presented in the United States mostly on the Public Broadcasting System (PBS), thereby underlining the notion of Shakespeare as a highbrow figure. Like the movie versions, television presentations have contributed to both perpetuating and reconfiguring the myth of Shakespeare's greatness. I say, "myth" of greatness, because movies and TV versions, like contemporary staged versions of the plays, frequently indulge in ingenious devices, attention-grabbers that obscure rather than reveal what actually makes Shakespeare's works great. One could argue that, no matter how changed they are in their form, the plays still do survive, and that their adaptability offers one reason why they live on. But, even if we accept this argument, the very fact that producers and directors have felt the need to resort to undisguised contrivance helps to solidify the position of Shakespeare's writings as highbrow fare. At the same time, paradoxically, film and stage productions enhance the widespread popularity of Shakespeare's celebrity status, for they act as signifiers even if what is being signified is amorphous or obscure.

In addition to the ready availability of movies and television, there are always stage productions of Shakespeare's plays to be seen in the United States, whether in schools, colleges, regional theaters, festival theaters, or on Broadway. Other countries, especially the UK, also have a continuous stream of productions. Moreover, his works have always inspired composers of operas, Broadway musicals, and orchestral pieces, as well as choreographers of ballets and modern dance; to this day they continue to do so. Consequently, more than any other literary figure, Shakespeare has been exceptionally well represented in both music and dance. In sum, wherever we turn, it seems, we are reminded of this larger-than-life figure and the high esteem in which he is held even among those who have no idea what he has achieved, let alone why he deserves such acclaim. 
But how did Shakespeare become an incomparable icon? When Shakespeare, as a young playwright, first arrived in London in the 1580s, Christopher Marlowe was the Shakespeare of the day, the most wellknown dramatist in a rapidly expanding commercially profitable form of entertainment. As both dramatists well understood, playgoing was fast becoming an important source of commercialism in London's growing economy, and, as a result, the need for new plays was constant and increasing. As we saw in Chapter 3, it was also the era in which actors first became celebrities and playwrights intensified their efforts to write dramas about figures who had achieved fame during the course of history. From hearing or even reading the Prologues to the two parts of Marlowe's Tamburlaine plays, ${ }^{11}$ Shakespeare must have learned that his fellow comrade-in-arms and role model had initially set out to change the course of English playwriting, to give it stature by combining elements of classical epics and drama. ${ }^{12}$ Although Marlowe died an untimely death at the young age of twenty-nine, he nevertheless achieved his goal-a feat that Shakespeare undoubtedly witnessed and took into account in his own writings. The first Tamburlaine play was so successful that Marlowe followed it up with an equally successful sequel; in fact, it seems that no play written in the sixteenth century had such an impact on other dramatists as the two Tamburlaine plays. ${ }^{13}$

In the early 1590s, Marlowe and Shakespeare worked out of the same theater, the Rose Theatre, for at least a couple of years. Consequently, Shakespeare was able to garner from his fellow poet and playwright many successful dramaturgical and linguistic techniques, ranging from pragmatic to aesthetic elements and including how to compose a play popular enough to require a sequel-as the Henry VI plays and the second part of Henry $I V$ reveal. Specifically, Shakespeare appears to have been influenced by three crucial innovations: Marlowe's verbal dexterity, his flexibility in reconfiguring standard notions of genre, and his use of ambivalence and ambiguity. More generally, Marlowe's imaginative daring and his determination to change the direction of English drama influenced Shakespeare. During the 1590 s, the theater was emerging as a major form of entertainment, an ideal context for someone with an imagination powerful enough to excel and become known for excelling. Moreover, the popularity of dramatic productions was not limited to Londoners, but also extended to those audiences who attended the performances of touring companies in smaller towns throughout the country, especially at those times when the plague was rampant in London. After Marlowe's death, Shakespeare rode 
the crest of a wave, immersing himself in the theater with all its collaborative complexities to combine with unqualified success both aesthetics and commercialism.

The earliest comments on Shakespeare remark on his astonishing ability as a playwright and poet. ${ }^{14}$ Except for one outstanding exception by Robert Greene, all the comments are favorable. We have already acknowledged that unfavorable criticism does not in any way impede one from becoming a celebrity. On the contrary, even notoriety can enhance one's renown or establish one's fame or status as a celebrity. The first extant comment on Shakespeare is an example of this seeming paradox. In 1592, when the playwright was twenty-eight, Robert Greene who, unlike Shakespeare, had university degrees, wrote a pamphlet familiar to Renaissance students and scholars, $A$ Groatsworth of Wit, bought with a million of repentence. In it, he complains:

there is an upstart crow, beautified with our feathers, that with his tiger's heart wrapped in a player's hide supposes he is as well able to bombast out a blank verse as the best of you; and, being an absolute Johannes Factotum [jack-of-all-trades] is in his own conceit the only Shake-scene in a country. ${ }^{15}$

A playwright himself, Greene enviously attacks Shakespeare, first calling him a pretentious "upstart crow"-perhaps because Shakespeare was an actor as well as a dramatist or perhaps because Shakespeare had no university education. Greene then snidely accuses him of cruelty by reworking a line from 3 Henry VI (1.4.137) in which the Duke of York excoriates Queen Margaret, who has defeated his forces in battle, imprisoned him, and mocked him unmercifully: the words a tiger's heart wrapped in a woman's hide, venomous in context, become even more vitriolic and personal when Greene changes "a woman's hide" to "a player's hide." This charge is even more puzzling in its obscurity than "upstart crow." Greene concludes his invective by complaining that Shakespeare is a Johannes Factotum, as a writer and an actor, a jack-of-all-trades, who is arrogant and insufferably egotistical about his overly ambitious achievements. Although the specific accusations of Greene's diatribe are unclear, the denigrating tone certainly is not. Unclear as well are the words of Henry Chettle a few months later who came to Shakespeare's defense in a tract entitled KindHeart's Dream. ${ }^{16}$ At about this same time, another contemporary, Thomas Nashe, in Pierce Peniless his Supplication to the Devil (1592), pays tribute to Shakespeare by praising the first of the playwright's three earliest 
Henry VI plays. ${ }^{17}$ These dramas were being performed at the Rose Theatre, owned by Philip Henslowe, whose scrupulously detailed records in his diary of the day-to-day workings of the productions there present evidence of Shakespeare's earliest successes. ${ }^{18}$ Together, Nashe and Philip Henslowe make clear that the Bard's earliest plays were well received and popular. That eight or nine of Shakespeare's plays were published by 1598 , and not by him, further attests the continuation and heightening of his popularity.

In 1598, Francis Meres in his volume, Palladis Tamia: Wit's Treasury, lavishes praise upon Shakespeare for both his poetry and his plays. ${ }^{19}$ Evaluating England's literary scene at the end of the sixteenth century, Meres compares modern writers with their ancient counterparts and claims that Shakespeare achieves the kind of excellence in both comedy and tragedy that the Latin writers Plautus and Seneca achieved respectively in each of these genres. He also praises Shakespeare as a first-rate poet. Meres's encomium is probably the first clear testimony of Shakespeare's widespread acclaim and a solid indication that the poet/playwright will emerge as something more than a momentary celebrity. Cultural support for this view comes with the increasing tendency of writers of the late sixteenth century and beyond to be identified as the creators of their works and with the elevation of the stature of drama as a creditable form of composition. Ostensibly, Ben Jonson took the boldest step in establishing each of these propensities when he published a collection of his works containing both plays and poetry and called the volume The Works of Benjamin Jonson (1616). The word "Works" was a designation that brought him considerable ridicule and mockery, but it also left an imprint in the sand that never washed away.

With the death of Shakespeare in 1616 and the subsequent publication of his plays in the First Folio Edition of 1623 by his colleagues, the actors John Heminges and Henry Condell, the playwright's continuance as a celebrated figure was assured. The previous publication of several of his plays in pirated editions suggests that he was already well known enough to have something of a reading audience. The Folio publication marks the most essential step in the ongoing process of becoming famous, because it gives permanent, verifiable proof of Shakespeare's achievement. The eulogies and tributes began, however, even before the burst of commendatory verses that prefaced the First Folio Edition and, again, the Second Folio Edition of 1632. Poetic tributes by William Basse and John Taylor, as well as a monument to Shakespeare in Holy Trinity Church in Stratford, 
all supply evidence of the Bard's spreading fame before the First Folio appeared. ${ }^{20}$ The First Folio Edition contains the most well-known tribute to Shakespeare in a poem by Ben Jonson, who as a playwright and poet was not always as laudatory and uncritical of his older contemporary. ${ }^{21}$ In his poem, "To the Memory of My Beloved the Author, Mr. William Shakespeare, and What He Hath Left Us," Jonson echoes Meres, for he generously compares Shakespeare with the best of Greek and Roman dramatists, claiming that Shakespeare can hold his own, because "He was not of an age, but for all time." In addition to other tributes, the First Folio also contains commendatory poems by Hugh Holland, Leonard Digges, and I. M. (James Mabbe?). The Second Folio includes these eulogies and adds others to them.

Meanwhile, more tributes begin to emerge: in Michael Drayton's 1627 elegy, Battaile of Agincourt, in poems and in dramatizations of Shakespeare's plays by Sir William Davenant, poems and epigrams by Thomas Bancroft, and in the anonymous Wits Recreations (1640). In the 1640 edition of Shakespeare's Poems, still more new eulogies appear. In his online article, "Shakespeare's Eulogies," David Kathman, has neatly summarized the tributes to Shakespeare from his death until the publication of the 1640 edition of his Poems:

Four years after Shakespeare's death, he was included in a printed tribute to England's greatest deceased poets; sometime in the first seven years after his death, a monument was erected to him in Stratford, and another poem, widely circulated in manuscript, suggested that he should have been buried in Westminster Abbey; seven years after his death, a massive edition of his plays was published along with four eulogies, the longest and most affectionate of them written by England's poet laureate [Ben Jonson]; around the same time (and possibly earlier) another manuscript eulogy was circulating; and over the next twenty years a dozen new eulogies appeared in print, including three in the second edition of his plays and three in an edition of his poems. ${ }^{22}$

By our contemporary standards, this summary probably seems meager. But in seventeenth-century England, it would have been considered remarkable. As a result of restrictions imposed by the ingrained class system, the only eulogies to appear in print normally were those paying homage to the nobility. Moreover, plays were just beginning to be considered important enough to be categorized as literature. The publication of the First Folio not only gave impetus to the creation of Shakespeare's permanent fame 
but also legitimacy to Jonson's claim, implicit in using "Works" in the title of his collection, that he was a serious writer and that his plays were serious literature.

John Milton, the next especially noteworthy literary champion of Shakespeare's works, prefixed to the Second Folio (1632) "An Epitaph on the Admirable Dramatic Poet, W. Shakespeare" (1630) in which he writes: "Thou in our wonder and astonishment / Hast built thyself a livelong Monument" (1l. 7-8). ${ }^{23}$ These lines pinpoint familiar, essential ingredients in the process of achieving and sustaining fame: "wonder and astonishment." We have already seen Shakespeare's similarly high regard for these elements in Antony and Cleopatra. In referring to the texts of Shakespeare's dramas, such responses also support Jonson's pronouncement that his fellow playwright is "not of an age, but for all time!" Later in the century, during the Restoration, John Dryden, himself celebrated as a prolific writer of prose, poetry, and drama, gave another strong boost to Shakespeare's growing reputation. And, again, like Jonson, he both criticized and commended the playwright, although the praise far outstrips the strictures. ${ }^{24}$ Moreover, he reworked three of Shakespeare's plays: The Tempest, Troilus and Cressida, and Antony and Cleopatra, the last of which, All For Love, is his most renowned adaptation; all three indicate that the tradition of Shakespearean influence through adaptations was well under way. Dryden's impressive pronouncements about Shakespeare, both in poetry and prose, are quoted often enough to be familiar. For example, in An Essay of Dramatic Poesy, he states that Shakespeare "was the man who of all modern, and perhaps ancient poets, had the largest and most comprehensive soul." ${ }^{25}$ In comparing Jonson with Shakespeare, Dryden concludes, "I admire him [Jonson], but I love Shakespeare." 26 This declaration plainly identifies the emotional connection with Shakespeare's dramas that continues to this day among students, teachers, scholars, critics, directors, actors, and those captivated audience members who do not belong to any of these categories.

Also during the Restoration, a division between the audiences of printed editions of Shakespeare's plays and performances of them becomes apparent. Part of the reason why the texts and the productions catered to markets independent of one another is that there were more adaptations than traditional performances of the texts. For instance, between 1660 and 1682, at least 72 percent of the Shakespeare plays performed were adaptations. ${ }^{27}$ This tendency marks the potency of the division between 
those who appreciated Shakespeare because of their reading knowledge of the texts and those who appreciated him because of the adaptations that he inspired.

However, not all the commentary on Shakespeare can be called encomiastic, and the negative remarks can be as forceful as the praise. For example, in 1693, Thomas Rymer roundly criticized Othello in what has remained a source of discontent among those who feel the handkerchief too flimsy an excuse for Othello's jealousy. In 1731, Voltaire expresses a similar disenchantment with the machinations of Shakespeare's plots and voices harsh criticism of Julius Caesar and Hamlet. ${ }^{28}$ Both Rymer and Voltaire show once again that fame is not solely dependent upon laudatory hyperbole. Voltaire's criticism of Shakespeare also suggests, unsurprisingly, that the latter's fame was spreading globally.

During the eighteenth century, the number of editions of Shakespeare's plays burgeoned as the number of readers of Shakespeare's works increased. Between the years of 1709 and 1821, eleven major editions of Shakespeare's plays were published-an astonishing number. In the middle of the century, translations of Shakespeare's works also began to appear with some frequency in Europe. In 1709, Nicholas Rowe, the first of the eighteenth-century editors, published his edition of Shakespeare's plays. Other editions soon followed. They include those of Lewis Theobald (1733), Thomas Hanmer (1744), who bears the unmeritorious distinction of having produced the worst edition of the plays, William Warburton (1747), and Edmond Malone (1790). Two leading literary figures, Alexander Pope (1725) and Samuel Johnson (1765), also edited the plays, both bestowing great impetus to the spreading fame of the playwright through their critical insights as well as through their editions. Although both writers criticized Shakespeare, it is their affirmations of the playwright's genius that are most conspicuous. Pope boldly announced in the Preface to his edition, for example, "If ever any Author deserved the name of an Original, it was Shakespear.... The Poetry of Shakespear was Inspiration indeed: he is not so much an Imitator, as an Instrument, of Nature; and 'tis not so just to say that he speaks from her, as that she speaks thro' him." ${ }^{29}$ Before discussing Shakespeare's faults, Pope cautions, "To judge ... of Shakespear by Aristotle's rules, is like trying a man by laws of one country, who acted under those of another." ${ }^{30}$ Johnson's well-known "Preface to Shakespeare" contains such memorable psychomoral statements as 
Nothing can please many, and please long, but just representations of general nature. ... Shakespeare is, above all writers, at least above all modern writers, the poet of nature, the poet that holds up to his readers a faithful mirror of manners and of life. ... This therefore is the praise of Shakespeare, that his drama is the mirror of life. ${ }^{31}$

Both Pope and Johnson offer criticisms of Shakespeare's artistry but both speak enthusiastically about the naturalness of his writings. Furthermore, both writers use the authoritative language of absolutes to characterize Shakespeare's fame. He could be described in such a manner because, evidently, in spite of the defects mentioned by his eighteenth-century editors and critics, he was already well accepted as England's premier playwright.

As the eighteenth-century interest in Shakespeare flourished, more and more editors began to annotate, emend, and even rewrite parts of Shakespeare's texts. Moreover, it was during this same century that the playwright and his works become the objects of intense, widespread critical scrutiny, including that of such outspoken continental figures as Augustus Wilhelm von Schlegel. ${ }^{32}$ Whereas in the nineteenth century scholars and critics of Shakespeare dwell on the psychology of composition and focus more on his individual characterizations than on the editing of texts and the elements of style and form in the plays, just the opposite appears to have been true in the eighteenth century. Both periods, however, show an interest in the focus of the plays, although they do not always agree on just what that focus is. Significantly, in both centuries, however, Shakespeare's fame was being heralded not only by the theatergoers flocking to his plays but by an ever-increasing reading public eager to discover what the clamor was about.

Every century tends to remake Shakespeare in its own image or images; the same is true for periods within centuries. As Russ McDonald observes, "What we call 'Shakespeare' is an artistic phenomenon resulting from an interaction between an early modern playwright's words and the environment in which they are heard or read." ${ }^{33}$ But perhaps the most striking shift in attitude toward Shakespeare's enduring fame occurs as we move into the nineteenth century. Simply put, during this century he becomes enshrined; the idolatry of Shakespeare becomes an unquestioned phenomenon. That is not to say that he and his works were above criticism during this period. But the severity of the criticism diminishes as the Bard is exalted. Samuel Taylor Coleridge, for example, expresses his attitude and that of many others toward the poet and playwright in a letter when 
he speaks of the "divinity of Shakespeare." In moving from the predominance of sociopolitical concerns in the eighteenth century to the behavior of the individual in the nineteenth, forcefully abetted by the advent of psychology, the attributes of Shakespeare the creative genius come more into focus. For example, in a well-publicized letter to his brothers George and Thomas, John Keats sets forth his idea of negative capability, using Shakespeare as his prime example. He is talking about

what quality went to form a Man of Achievement especially in Literature \& which Shakespeare posessed [sic] so enormously-I mean Negative Capability, that is when man is capable of being in uncertainties, Mysteries, doubts, without any irritable reaching after fact $\&$ reason. ${ }^{34}$

A psychological characteristic that can be applied to anyone, negative capability characterizes a trait essential to successful creative writers and to Shakespeare in particular. It delineates an imaginative projection in which the writer is so deeply engaged emotionally with characters in specific situations that he or she blocks out interference and distractions from his or her rational faculties. Keats's description illuminates a chief element in the psychology of composition and is intended to explain Shakespeare's success in creating the characters of his plays. In addition to such written analyses and tributes, nineteenth-century theater continues to pay tribute to Shakespeare's plays and manages to attract those who are knowledgeable about Shakespeare as well as those who are not, thereby ever widening the circle of admirers. Finally and most essentially, during the latter part of this century, the study of Shakespeare's works becomes a standard part of school curricula on all levels, both in Britain and the United States. It does so because English literature is established as a discipline, displacing the previous emphasis on the classical literature of the Greeks and Romans. This phenomenon alone guarantees that the genuine reasons for Shakespeare's status as a person of fame will remain permanently inscribed and open to view. The study of Shakespeare and his works in schools continues to serve the same function today and has been expanded to many countries where English is not the primary language. Without a doubt, more people are studying Shakespeare today than at any other time in the last four centuries.

During the first half of the nineteenth century, Shakespeare's fame spread more widely across Europe and beyond than it had earlier. It also reached the United States where, after having been firmly rejected by the 
earliest English Puritan settlers, it received an enthusiastic welcome. The chief reason is that Shakespeare's works were as popular as lowbrow entertainment as they were in highbrow circles. They were especially popular in the West, the plays even being performed in frontier saloons. Moreover, in one instance, Shakespeare was indirectly responsible for a highly newsworthy incident of tragic violence. On May 10, 1849, the English actor William Charles Macready performed his signature role in Macbeth in New York City and provoked a riot that brought out the National Guard and resulted ultimately in thirty-one deaths and in many more injuries. Apparently, the origins of this riot lay in the political-cultural tensions between America and Britain and in the rivalry between Macready and Edwin Forrest, his American challenger to Shakespearean acting supremacy. This event indicates how quickly and deeply embedded in American culture the status of Shakespeare had become.

As we follow the development of Shakespeare's fame into the twentieth century, we see that his celebrity status is widespread enough to be used in common television advertisements. Two powerful trends that bear on the process of achieving imperishable fame clearly emerge during this century. First, the aforementioned bourgeoning Shakespeare industry; among scholars, critics, and students of Shakespeare, the Bard was never more popular-learned journals were exclusively devoted to his works, innumerable critical books and articles flooded the libraries of academe and still do. National and international Shakespeare conferences take place on a regular basis. In England, largely thanks to an American, Sam Wanamaker, Shakespeare's Globe theater was reproduced and continues to this day to attract people from all over the world to see Shakespeare's plays. In 2014, on the grounds of the Globe, the Sam Wanamaker Playhouse, recreating an indoor Jacobean theater, opened its doors; this venue allows the staff of Shakespeare's Globe to present plays throughout the year. Secondly, because of the imaginative ways in which his plays are presented on stage and screen, the distance from the Bard's texts increases even as the real reasons for his fame fade. At the end of the twentieth century, Linda Charnes wrote that

the nature of what has been attached to Shakespeare's name has changed. ... 'Shakespeare' has come to function in contemporary culture more as vehicle than as author ... The nature of Bardolatry in postmodern culture is different from that of Bardolatry in the last century ... Bardolatry now is more widespread and less informed, 
consisting not of knowledge of the plays but of awareness of their presence in the cultural 'background' as universal arbiters: removed but vigilant trustees of Western culture's enduring ideological provenance. ${ }^{35}$

The trend that Charnes pinpoints has only increased in the twenty-first century, as has the popularity of designating all manner of people as celebrities. The staging of the plays and what we might call the staging of the playwright's reputation have come to be the result of collaboration and confusion, neither of which is new. In the case of the staging of the plays, the confusion stems chiefly from the attempts to escape from the language of Shakespeare, which sounds increasingly arcane to our ears, and, in the case of his reputation, from the lack of knowledge about the details of his biography and his works. Even so, we are faced with a patent irony, for as the legitimate reasons for his fame become increasingly obscure, his fame becomes more deeply infused and more widespread-for many, a useful cultural commodity.

In Antony and Cleopatra, Shakespeare's dramatization of the components of imperishable fame takes into account a number of interrelated elements. To begin with, the two protagonists were renowned as historical persons long before their appearance in the play, originally because of their sociopolitical powers as figureheads in the highest echelon of society. Thus, they were individually celebrated largely, though not exclusively, for their public, professional achievements. Once they became lovers, their relationship generated greater, more widespread interest than their professional lives among writers and their audiences. Therefore, Shakespeare knew that, in dramatizing the relationship, he was building on a solid foundation. In his telling of the story, he chose to focus on the couple's personal actions and attitudes during the compressed, last ten years of their lives and the depth of their bond-probably in part because he was naturally drawn to creating situations that enabled him to portray the imagined vagaries of human behavior, especially those of famed lovers. Secondly, we know that, over the course of his career, Shakespeare appears to have become increasingly disenchanted with both the invasiveness of sociopolitical demands, which can result in the loss of one's creative independence and individuality, and with the obstacles that must be overcome in establishing and sustaining the wellbeing of the political state. 
As a result, he willingly departs from historical accuracy to dramatize this conflict, revealing, as we have seen, some of his own seasoned biases in the process.

The play keeps reminding us that Antony's reputation has been created largely in the past and is based on his feats as a heroic warrior and military leader rather than as a political figure. Even at his most deserving, Antony is not portrayed as someone who has performed invaluable service to the state but as someone who has achieved personal glory instinctively and spontaneously. In establishing a major focus in his characterization of Antony, Shakespeare accentuates the hero's uncanny ability to inspire devotion-in his followers, as well as in women-but especially in Cleopatra, whose constancy is all the more remarkable given her imperial position, changeable personality, and extensive resources. We emerge from the play with a stronger felt experience of Antony's greatness in inspiring loyalty than with his greatness in his accomplishments as either a military commander or a triumvir. This trait and Antony's magnanimity are Shakespeare's chief additions to the development of his protagonist's famed greatness and help implicitly to bind his past accomplishments to the present.

In characterizing Cleopatra, we have seen throughout the play that Shakespeare chooses to maintain a focus exclusively on her private life. Historically, we know that Cleopatra's fame derived initially from events in her life related to her position as a Ptolemy and as a queen and had nothing to do with Antony. Shakespeare's concentration so exclusively on Cleopatra's relationship with Antony rules out the possibility of portraying the causes of her fame as an admirable world leader. Had he stressed her actual political achievements, her keen intelligence (including her knowledge of nine languages), and her shrewd abilities as a negotiator, his task might have been easier. But, clearly, he is interested in her ability to transcend herself as a human being, albeit a royal personage, rather than as a political figure. In this choice, he is likely playing to the tastes of his audiences, based on the centuries-old fascination with the amatory relationship between the two protagonists. Thus, audiences of theatergoers and readers are asked to focus on the two lovers' ability to transform themselves momentarily into extraordinary human beings even if their misconceptions about themselves and others and the force of external circumstances all too often prevent them from achieving such transformations with consistency. When, having extricated themselves from the self-destructive elements in their personalities and from the conditions 
inflicted on them by their sociopolitical environment they display their autonomy, we admire them unconditionally and wish to acknowledge and support their fame. The play asks us to marvel at them, especially at their deaths, when they transcend all that is ordinary and debilitating in themselves and subvert the humdrum meanderings and unjust excrescences of "this wild world" (5.2.308).

In putting the complicated relationship between Antony and Cleopatra front and center on the stage at a time when theatrical representations of historical figures and the idea of celebrities among actors were firmly in place and gaining momentum, Shakespeare amplified widespread public interest in his protagonists as paragons but, remarkably, without losing sight of the fact that they were also tarnished. Evidently secure in his abilities as a dramatist, he attempted to convince his audiences, in contradistinction to the Romans in the play, not to oversimplify their responses to Antony and Cleopatra. In addition to his trust in his mastery of his craft, the pragmatic businessman in him knew that dramatic productions as a form of entertainment were steadily gaining in popularity and had become, irresistibly, a commercially viable source of income. Overall, the conditions of the theater culture of 1606-8 must have not only given sanction but a boost to his creative independence and confidence in focusing on the personal relationship of the lovers and on heralding their prominence as famed figures.

Shakespeare evokes awe or wonder as a major response to his "peerless" "mutual pair" not only among those in the world of the play but in his theater audiences. Nevertheless, because of the stylized language, audience members remain sufficiently detached, not becoming so emotionally involved that they block out their rational understanding of the lovers' triumphant and not-so-triumphant actions and reactions. Whether we are struck by their mistakes and faulty perceptions or by their ability to transcend their humanity, our curiosity is held captive because we know that something new and personal about these famous "it" figures is being suggested. We may be surprised by Antony's rush to judgment in condemning Cleopatra and his anger at her or by Cleopatra's capacity for self-deception and her self-limiting vision, ${ }^{36}$ but we are also amazed and marvel at each protagonist's ability to exert renewed energy and make time appear to stand still: Cleopatra's ability to display her "infinite variety" and Antony's to achieve "infinite virtue." We know that, in appearing to transcend the constraints of mutability, even if only momentarily, Antony and Cleopatra reveal an essential capacity for transcending ordinariness. 
We willingly suspend our disbelief in their greatness, because Shakespeare has given us enough psychological understanding of the behavior of the couple, especially their failings, so that we are able to feel a common bond with their humanity and trust in their realness. Moreover, we are naturally curious to see the plausible development of a longstanding, sensationalized romantic relationship.

Finally, we need to answer one more question: how specifically are the sources of Antony and Cleopatra's fame parallel to the sources of Shakespeare's fame? Shakespeare and his two protagonists appear to have had freedoms that many people do not enjoy. Although somewhat reigned in by the commercial and dramaturgical demands of his theatrical culture, Shakespeare had greater autonomy in writing his plays than he imagines Antony and Cleopatra had in conducting their lives within their interwoven private and sociopolitical contexts. ${ }^{37}$ Even so, all three experience an unusual freedom that enables them to exercise their talents with freewheeling instinctiveness, thereby easing their pathways to imperishable fame.

In achieving superior feats, we have just seen that Antony and Cleopatra's evocation of awe or wonder is one of Shakespeare's artistic means for glorifying the lovers. As it so happens, our awe or wonder serves a similar function in glorifying Shakespeare. Amazingly enough, he has inadvertently managed to generate this same response for over five centuries. Moreover, whether in creating astonishment because of a conscious attempt to measure up to self-styled standards, Shakespeare and his protagonists at times knowingly or unknowingly project an image of selfglorification. Shakespeare's depictions of Antony, Cleopatra, and Octavius reveal that the playwright was well aware of the effects of self-glorification. In all probability he knew -if in fact he was so self-aware - that as a dramatist, in contrast to his characters, self-glorification could only be transitory. Chapter 1 suggested that when Shakespeare displays his verbal ingenuity with unrestrained enthusiasm, it is a sign that his authorial voice is breaking through the mask of character. This penchant can also be seen as self-glorification-a tendency more blatant at the beginning of his career than later when the integration of language and characterization become more harmonious. But without disputing the degree to which the dramatist also shares in his characters' conscious self-glorification, the effect of awe or wonder it creates in an appreciative audience seems a customary if not necessary ingredient for sustaining the fame of both the playwright and his dramatis personae. 
The uncertainties in the play can perhaps be understood in part as a reflection of the ambivalences created by previous conflicting depictions of the lovers. These depictions, in combination with the aesthetic use of ambiguity in plays by such contemporaries as Christopher Marlowe, may have given Shakespeare a license to envelop with frequent ambiguity the words and actions of the couple. In addition, we have seen that ambiguity is an important means of evoking and sustaining interest in the pair. As it so happens, we also have considerable ambiguity in our response to Shakespeare and his writings. The many uncertainties about Shakespeare's biography and his poetic and dramatic texts have created ambiguities that all levels of respondents have tried to resolve, some through fabricating myths about the $\operatorname{man}^{38}$ and several through scholarly studies intended to determine with exactness the meaning of his works. Ambiguity engages people by inviting them to use their imaginations and to speculate freely. Thus, whether in considering Shakespeare himself or Antony and Cleopatra (not to mention other of his works), ambiguity teases, ultimately tempting us to participate in the process of fame's enhancement and continuance.

Essential to the process of perpetuating a person's fame is the ability of that person to stimulate anew an unrestrained excitement among those who might add their responses to his or her fame. Shakespeare shares with Antony and Cleopatra the capacity to inspire others. Both figures inspire admiration and loyal devotion, Antony more obviously so than Cleopatra. In the Bard's case, the influence is widely spread among writers, directors, actors, students, teachers, scholars, spectators, and readers. His two protagonists have some understanding of their ability to inspire followers, but during his lifetime Shakespeare could not have known how far-reaching and permanent his influence would be. One additional reason for his longstanding fame can be accounted for by the principle that Octavius affirms when he declares, "High events as these / Strike those that make them; and their story is / No less in pity than his glory which / Brought them to be lamented" (5.2.354-57). In devising memorable characters of renown, it is impossible for Shakespeare's audiences not to think of the creator who brought them to life.

A standard practice among scholars, teachers, and students has been to link Cleopatra's instinctive imaginative powers with Shakespeare's until the Queen has become something of a surrogate for the playwright in her aptitude for staging and performing in scenes and in her ingenious use of language. It is, of course, she (and Shakespeare as puppet master), not Antony, who has the ability to "play one scene / Of excellent dissembling" 
(1.3.78-79). In Shakespeare's Late Style, Russ McDonald enumerates several of Cleopatra's extraordinary linguistic characteristics in Act 5,39 concluding that "It is unnecessary to elaborate on such poetic properties: what is important is that they sustain the association of Cleopatra with language and its creative powers" (p. 68). Clearly, this "association" is also Shakespeare's, an aspect of his "infinite variety," and it establishes a telling connection between a source of Cleopatra's fame and his own. In portraying and highlighting Cleopatra's dramaturgical capabilities and their effects and indicating that they redound to her fame, her creator, unknowingly, has served only to buttress his own.

If from Shakespeare's perspective Antony and Cleopatra best measure up when they give the appearance that the greatest of their actions renders the passage of time and its deleterious effects of little or no consequence, then the same standard might be applied to the playwright to explain why his works have transformed him into a person of exceptional fame. In creating characters whose behaviors can often be understood as just as relevant now as they were when he first set pen to paper, he has given longevity to himself as well as to his works. We continue to marvel at the ever-expanding power to defy change that he and his legacy have iconically evolved into. As a practicing playwright, Shakespeare may have understood that one way to ensure that he would measure up, doing his best to engross contemporary audiences in his plays, would be to add his voice in a singular way to the voices of others who had written about figures of permanent fame, transhistorical celebrities such as Antony and Cleopatra. He could not have realized, however, that, with this play specifically, he would outstrip those who, in writing about the renowned pair, came before and after him. With the greatness of Antony and Cleopatra, as well as that of his other plays and his poetry, he has not only managed to outface time and achieve everlasting eminence, but he has dramatized with indelible examples the connections between change and paradigms of fame. By a higher standard than he ever assumed, he has certainly more than measured up. Like Antony and Cleopatra's, Shakespeare's renown has become self-generating to the point where he is now famous for being famous. In exploiting the eternizing power of the written word, he has inadvertently produced a legacy that will exist as long as time remains. As with Antony's death, even though "the star is fallen" (4.14.108), Shakespeare's death marked the beginning of his life as a figure of imperishable fame. 


\section{NOTES}

${ }^{1}$ Quantitative analysts Steven Skiena and Charles B. Ward in their book, Who's Bigger: Where Historical Figures Really Rank (Cambridge: Cambridge University Press, 2014), seek to classify the most significant individuals who have ever lived. In their selection of the most significant individuals who have influenced the course of history and society, Jesus is ranked first, Napoleon second, Muhammad third, and Shakespeare fourth (p. 5). Shakespeare is the only literary or artistic figure to make the list of the top fifty persons. In their ranking of the most influential literary figures who have ever lived, Shakespeare (predictably) is number one (p. 278). The complicated statistical methodology of the authors apart, the rankings indicate the importance and uniqueness of Shakespeare's enduring fame.

${ }^{2}$ An advertisement for a Boston, April-May 2011 production of Antony and Cleopatra contained the following description, which is indicative of the way the notion of the celebrity status of the lovers has found its way into the list of compelling reasons for attending a performance:

Antony and Cleopatra brings us close to great leaders and iconic lovers in the tumult of a changing world. Greatness pervades the play, but when the façade of greatness begins to crack, things spin out of control and our heroes engage in a great human scramble to protect their stature and power. Cleopatra becomes trapped in a cage of celebrity. Antony makes mistakes and cannot recover. This beautiful and tragic play allows us to experience, in one intimate evening, the heights that we want but cannot have, and take us on a personal journey into greatness, celebrity, sacrifice, love and loss.

(http://www.americantowns.com/ma/boston/events/ performance-antony-and-cleopatra-3-2011-05-22; my italics)

The facile attachment of "celebrity" to the play makes clear how easy it is to assign this same status to the playwright.

${ }^{3}$ Mentioned by Francis Meres in 1598 in Palladis Tamia as circulating privately among Shakespeare's friends and published by Thomas Thorpe in 1609, but, as far as we know, not authorized by Shakespeare.

${ }^{4}$ I am reminded as I use the term "household words" that it was first used by Shakespeare in Henry V's well-known Agincourt speech (Henry V 4.3.53), one more indication of just how pervasive his influence has become.

${ }^{5}$ Interestingly, the protagonists of Romeo and Juliet and Hamlet have come to be recognized as celebrities themselves. As we saw in Chapter 3, fictional characters, like actual persons, can be a reflection of the universal psychological need to create larger-than-life exemplary figures.

${ }^{6}$ Stephen Greenblatt, Will in the World: How Shakespeare Became Shakespeare (New York: W. W. Norton, 2004). 
${ }^{7}$ A relatively recent book by a professor of constitutional law at New York University exemplifies Shakespeare's ascension into the ranks of those with superior moral knowledge: Kenji Yoshino, A Thousand Times More Fair: What Shakespeare's Plays Teach Us About Justice (New York: Ecco/HarperCollins Publishers, 2011).

${ }^{8}$ For the factual information here about Shakespeare and silent films, I am indebted to Samuel Crowl, Shakespeare and Film: A Norton Guide (New York: W. W. Norton, 2008), pp. 3-6. According to Crowl, "a four-minute scene from Shakespeare's King John featuring the noted classical actor Sir Herbert Beerbohm Tree" (p. 3) was the first film version based on a Shakespeare play.

${ }^{9}$ Kozintsev: Hamlet (1964) and King Lear (1970); Olivier: Henry V (1944), Hamlet (1948), and Richard III (1955); Kurasawa: Throne of Blood [Macbeth] (1957), The Bad Sleep Well [Hamlet] (1960), and Ran [King Lear] (1985); Welles: Macbeth (1948), Othello (1952), King Lear (1953), and Chimes at Midnight (1966); Zeffirelli: The Taming of the Shrew (1966), Romeo and Juliet (1968), Verdi's Otello (1986), and Hamlet (1990); Branagh: Henry V (1989), Much Ado About Nothing (1993), Hamlet, (1996), Love's Labour's Lost (2000), As You Like It (2007), and The Winter's Tale (2015).

${ }^{10}$ Most recently, in 2013, he assumed the role of Macbeth in a stage production of the play at the Manchester International Festival in England. In May of 2014, he brought the production to New York City. Rumor has it that he intends Macbeth to be his next Shakespearean film.

${ }^{11}$ The Prologue to Part 1 of Tamburlaine (lines 1-8):

From jigging veins of rhyming mother-wits, And such conceits as clownage keeps in pay, We'll lead you to the stately tent of war, Where you shall hear the Scythian Tamburlaine:

Threat'ning the world with high astounding terms And scourging kingdoms with his conquering sword.

View but his picture in this tragic glass, And then applaud his fortunes as you please.

The Prologue to Part 2 of Tamburlaine (lines 1-9):

The general welcomes Tamburlaine received When he arrivèd last upon our stage Hath made our poet pen his second part, Where death cuts off the progress of his pomp And murd'rous Fates throws all his triumphs down.

But what became of fair Zenocrate,

And with how many cities' sacrifice

He celebrated her sad funeral,

Himself in presence shall unfold at large. 
${ }^{12}$ For an extensive treatment of the influence of Marlowe's works on Shakespeare, see Logan, Shakespeare's Marlowe.

${ }^{13}$ For a discussion of the influence of the Tamburlaine plays on contemporary dramatists, see Peter Berek, "Tamburlaine’s Weak Sons: Imitation as Interpretation Before 1593," Renaissance Drama n. s., 13 (1982): 55-82.

${ }^{14}$ For a discussion of contemporary comments on Shakespeare and his works, see Samuel Schoenbaum, William Shakespeare: A Compact Documentary Life (Oxford: Oxford University Press, 1977), pp. 147-58, 189-95, 255-59.

${ }^{15}$ Alexander B. Grosart, ed., The Life and Complete Works in Prose and Verse of Robert Greene, vol. 12 (New York: Russell and Russell, 1881-86), p. 144.

${ }^{16}$ See E. K. Chambers, William Shakespeare, vol. 2 (Oxford: Clarendon Press, 1930) p. 189.

${ }^{17}$ R. B. McKerrow, ed., The Works of Thomas Nashe, vol. 1 (London: A. H. Bullen, 1904-10; revised by F. P. Wilson, Oxford: Basil Blackwell 1966), p. 212.

${ }^{18}$ R. A. Foakes, ed., Henslowe's Diary, 2nd ed. (Cambridge: Cambridge University Press, 2002).

${ }^{19}$ Schoenbaum, William Shakespeare, pp. 189-92.

${ }^{20}$ SeeDavidKathman, “Shakespeare'sEulogies," http://shakespeareauthorship. com/eulogies.html [accessed April 3, 2011] $\$ 2-3$. Kathman quotes the Latin inscription on the front of the monument and the familiar poem that follows it, both praising Shakespeare's extraordinary talent.

21 The evidence for Jonson's criticisms of Shakespeare is to be found in his "Conversations with Drummond" and "Discoveries." See Ben Jonson, ed. C.H. Herford and Percy and Evelyn Simpson, 11 vols. (Oxford: Clarendon Press, 1925-52). For excerpts of these criticisms and commentary, see Logan, Shakespeare's Marlowe, pp. 166-67.

${ }^{22}$ Kathman, “Shakespeare's Eulogies," pp. 11-12.

${ }^{23}$ John Milton: Complete Poems and Major Prose, ed. Merritt Y. Hughes (Indianapolis: Odyssey Press, 1957), p. 63. For a detailed, comprehensive history that begins with the Restoration and describes the evolution of Shakespeare's emergence as a figure of importance whose works are worth serious scrutiny, see Gary Taylor, Reinventing Shakespeare: A Cultural History from the Restoration to the Present (London: Hogarth Press, 1990).

${ }^{24}$ As Arthur M. Eastman points out in A Short History of Shakespearean Criticism (New York: W. W. Norton, 1968), pp. 6-7, Dryden's criticisms had more to do with style than content.

${ }^{25}$ John Dryden, The Selected Works of John Dryden, ed. William Frost (New York: Holt, Rinehart and Winston, 1963), p. 363.

${ }^{26}$ Dryden, Selected Works, p. 366.

${ }^{27}$ Richard Finkelstein, "Review of Marketing the Bard: Shakespeare in Performance and Print 1660-1740 by Don-John Dugas (Columbia, MO and London: University of Missouri Press, 2006)," Shakespeare Quarterly, 58, no. 2 (2007): 255-56. 
${ }^{28}$ For more details about both Rymer and Voltaire, see Eastman, Shakespearean Criticism, pp. 5-6.

${ }^{29}$ The quotations from Alexander Pope are from Poetry and Prose of Alexander Pope, ed. Aubrey Williams (Boston: Houghton Mifflin, 1969). This one appears on p. 460.

${ }^{30}$ Pope, Poetry and Prose, p. 462.

${ }^{31}$ Samuel Johnson on Shakespeare, ed. W. K. Wimsatt, Jr. (New York: Hill and Wang, 1960), pp. 25-27.

${ }^{32}$ For a discussion of Von Schlegel's Shakespearean criticism, see Eastman, Shakespearean Criticism, pp. 35-51.

${ }^{33}$ Russ McDonald, The Bedford Companion to Shakespeare: An Introduction with Documents, 2nd ed. (Boston: Bedford/St Martin's, 2001), p. 2.

${ }^{34}$ John Keats: Selected Poems and Letters, p. 261. This letter was cited in Chapter 2 (see Chapter 2 note 7), but in a different context.

${ }^{35}$ Charnes, Notorious Identity, p. 155.

${ }^{36}$ As I mentioned in Chapter 4, Cleopatra can be compared with Dido in her devaluing of and inattention to the political demands made on her lover.

${ }^{37}$ See the discussion of Shakespeare's autonomy in Chapter 3. If in Antony and Cleopatra Shakespeare could so drastically alter Virgil's account of Aeneas and Dido in Elysium through Antony's description ("Dido and her Aeneas shall want troops, / And all the haunt be ours" 4.14.53-54) and through the play's reversal of Virgil's emphasis on public over private values, his refashioning suggests that he felt he had an equally free hand in reworking previous depictions of Antony and Cleopatra. For a description of the differences between Virgil and Shakespeare, see Adelman, The Common Liar, pp. 68-70. On pp. 70-78, she describes what in the accounts of Virgil, Chaucer's The Legend of Good Women and The House of Fame, and Marlowe's Dido, Queen of Carthage, Shakespeare might have understood from "the significance of the composite story and the issues of value and perspective that the differing versions raised" (p. 69) and how "this composite story shaped Antony and Cleopatra decisively" (p. 69).

${ }^{38}$ Perhaps the most obvious are the attempts of the anti-Stratfordians to persuade us that Shakespeare was not the author of his plays.

${ }^{39}$ Russ McDonald, Shakespeare's Late Style (Cambridge: Cambridge University Press, 2006), p. 68. 


\section{Bibliography and Further Reading}

Adelman, Janet. The Common Liar: An Essay on Antony and Cleopatra. New Haven, CT: Yale University Press, 1973.

Anderson, Emily Hodgson. "Celebrity Shylock." Special Topic: Celebrity, Fame, Notoriety, PMLA 126, no. 4 (2011): 935-49.

Barroll, J. Leeds. "Antony and Pleasure." Journal of English and Germanic Philology 57 (1958): 708-20.

—. Artificial Persons. Columbia: University of South Carolina Press, 1974.

- Shakespearean Tragedy: Genre, Tradition, and Change in Antony and Cleopatra. Cranbury, NJ: Associated University Presses, 1984.

- "The Chronology of Shakespeare's Jacobean Plays and the Dating of Antony and Cleopatra." In Essays on Shakespeare, edited by Gordon Ross Smith, pp. 115-62. University Park: Pennsylvania State University Press, 1965.

Barton, Anne. "Nature's Piece 'gainst Fancy": The Divided Catastrophe in Antony and Cleopatra. London: Bedford College, 1973.

Belsey, Catherine. “Cleopatra's Seduction.” In Alternative Shakespeares, edited by Terence Hawkes, Vol 2. pp. 38-62. London: Routledge, 1996.

- The Subject of Tragedy. London; New York: Methuen, 1985.

Berek, Peter. "Tamburlaine's Weak Sons: Imitation as Interpretation Before 1593." Renaissance Drama n. s., 13 (1982): 55-82.

Bevington, David, ed. Antony and Cleopatra. Cambridge: Cambridge University Press, 2005.

Boone, Joseph and Nancy J. Vickers. "Introduction-Celebrity Rites." Special Topic: Celebrity, Fame, Notoriety, PMLA 126, no. 4 (2011): 897-911.

Bradley, Andrew C. "Shakespeare's Antony and Cleopatra." Lecture 9 in Oxford Lectures on Poetry. London: Macmillan, 1909.

Braudy, Leo. The Frenzy of Renown: Fame \& Its History. Oxford: Oxford University Press, 1986.

Brower, Reuben A. Hero and Saint: Shakespeare and the Greco-Roman Heroic Tradition. Oxford: Oxford University Press, 1971.

Calderwood, James L. Shakespeare and the Denial of Death. Boston: University of Massachusetts Press, 1987. 
Cerasano, S. P. "Edward Alleyn, the New Model Actor, and the Rise of the Celebrity in the 1590s," Medieval and Renaissance Drama in England 18 (2006): 47-60.

- "Theater Entrepreneurs and Theatrical Economics." In The Oxford Handbook of Early Modern Theatre, edited by Richard Dutton, pp. 380-95. Oxford: Oxford University Press, 2009.

Chambers, E. K. William Shakespeare: A Study of Facts and Problems. 2 vols. Oxford: Clarendon Press, 1930.

Charnes, Linda. Notorious Identity: Materializing the Subject in Shakespeare. Cambridge, MA: Harvard University Press, 1993.

Charney, Maurice. Shakespeare's Roman Plays: The Function of Imagery in the Drama. Cambridge, MA: Harvard University Press, 1961.

- Shakespeare on Love and Lust. New York: Columbia University Press, 2000.

—. Wrinkled Deep in Time: Aging in Shakespeare. New York: Columbia University Press, 2009.

Chernaik, Warren. The Myth of Rome in Shakespeare and His Contemporaries. Cambridge: Cambridge University Press, 2011.

Coleridge, Samuel Taylor. Coleridge's Writings on Shakespeare. Edited by Terence Hawkes. New York: G. P. Putnam's Sons, 1959.

Colie, Rosalie L. Shakespeare's Living Art. Princeton: Princeton University Press, 1974.

Cook, Albert. "The Transmutation of Heroic Complexity: Plutarch and Shakespeare." Classical and Modern Literature: A Quarterly 17, no. 1 (1996): 31-43.

Crane, Mary Thomas. "Roman World, Egyptian Earth: Cognitive Difference and Empire in Shakespeare's Antony and Cleopatra." Comparative Drama, 43, no. 1, (2009), 1-17.

Crowl, Samuel. Shakespeare and Film: A Norton Guide. New York: W. W. Norton, 2008.

Danby, John F. “The Shakespearean Dialectic: An Aspect of Antony and Cleopatra." Scrutiny 16, no.3 (1949): 196-213.

Danson, Lawrence. "Continuity and Character in Shakespeare and Marlowe." Studies in English Literature 1500-1900 26, no. 2 (1986): 217-34.

Davies, H. Neville. "Jacobean Antony and Cleopatra." Shakespeare Studies 17 (1985): 123-58.

Deats, Sara Munson, ed. "Antony and Cleopatra”: New Critical Essays. New York: Routledge, 2005.

- Sex, Gender, and Desire in the Plays of Christopher Marlowe. Newark: University of Delaware Press, 1997.

Deats, Sara Munson, and Logan, Robert A, eds. Marlowe's Empery: Expanding His Critical Contexts. Newark: University of Delaware Press, 2002.

Dickey, Franklin M. Not Wisely But Too Well: Shakespeare's Love Tragedies. San Marino: Huntington Library, 1957. 
Doty, Jeffrey S. “Shakespeare's Richard II, 'Popularity, and the Early Modern Public Sphere.” Shakespeare Quarterly 61, no. 2 (2010): 182-205.

Dryden, John. The Selected Works of John Dryden. Edited by William Frost. New York: Holt, Rinehart and Winston, 1963.

Dutton, Richard, ed. The Oxford Handbook of Early Modern Theatre. Oxford: Oxford University Press, 2009.

Eastman, Arthur M. A Short History of Shakespearean Criticism. New York: W. W. Norton, 1968.

Eliot, T. S. Four Quartets, "Burnt Norton," Part I. www.davidgorman. com/4Quartets/1-norton.htm

Esler, Anthony. The Aspiring Mind of the Elizabethan Younger Generation. Durham: Duke University Press, 1966.

Finkelstein, Richard. "Review of Marketing the Bard: Shakespeare in Performance and Print 1660-1740 by Don-John Dugas (Columbia, MO and London: University of Missouri Press, 2006).” Shakespeare Quarterly, 58, no. 2 (2007): 255-56.

Fitz, L. T. "Egyptian Queens and Male Reviewers: Sexist Attitudes in Antony and Cleopatra Criticism.” Shakespeare Quarterly 28 (1977): 297-316.

Foakes, R. A., ed. Henslowe's Diary. 2nd ed. Cambridge: Cambridge University Press, 2002.

Giles, David. Illusions of Immortality: A Psychology of Fame and Celebrity. London: Macmillan, 2000.

Goldsworthy, Adrian. Antony and Cleopatra. New Haven, CT: Yale University Press, 2010.

Greenblatt, Stephen. Shakespeare's Freedom. Chicago: University of Chicago Press, 2010.

- Will in the World: How Shakespeare Became Shakespeare. New York: W. W. Norton, 2004.

Grosart, Alexander B., ed. The Life and Complete Works in Prose and Verse of Robert Greene. 15 vols. New York: Russell and Russell, 1881-86.

Gurr, Andrew. Playgoing in Shakespeare's London. 3rd ed. Cambridge: Cambridge University Press, 2004.

- The Shakespeare Company, 1594-1642. Cambridge: Cambridge University Press, 2004.

- The Shakespearean Stage, 1574-1642. 4th ed. Cambridge: Cambridge University Press, 2009.

Hillman, David. "If it be love indeed': Transference, Love, and Anthony and Cleopatra." Shakespeare Quarterly 64, no. 3 (2013): 301-33.

Hirsh, James. "Rome and Egypt in Antony and Cleopatra and in Criticism of the Play." In "Antony and Cleopatra": New Critical Essays, edited by Sara Munson Deats, pp. 175-91. New York: Routledge, 2005.

Huffman, Clifford Chalmers and John W. Velz, eds. "The Rape of Lucrece," "Titus Andronicus," "Julius Caesar," "Antony and Cleopatra," and "Coriolanus": An 
Annotated Bibliography of Shakespeare Studies 1910-2000. Fairview, NC: Pegasus Press, 2002.

Johnson, Samuel. Samuel Johnson on Shakespeare. Edited by W. K. Wimsatt, Jr. New York: Hill and Wang, 1960.

Jonson, Ben. Ben Jonson. Edited by C. H. Herford and Percy and Evelyn Simpson. 11 vols. Oxford: Clarendon Press, 1925-52.

Jorgensen, Paul A. "Antony and the Protesting Soldiers: A Renaissance Tradition for the Structure of Antony and Cleopatra." In Essays On Shakespeare, edited by Gordon Ross Smith, pp. 165-75. University Park: Pennsylvania State University Press, 1965.

Kathman, David. "How Old Were Shakespeare's Boy Actors?” Shakespeare Survey 58 (2006): 220-45.

—. "Shakespeare's Eulogies." http://shakespeareauthorship.com/eulogies.html

Keats, John. John Keats: Selected Poems and Letters. Edited by Douglas Bush. Boston: Riverside Press, 1959.

Knight, G. Wilson. The Imperial Theme: Further Interpretation of Shakespeare's Tragedies Including the Roman Plays. London: Methuen, 1931.

Knights, Lionel C. Some Shakespearean Themes. London: Chatto and Windus, 1959.

Knutson, Roslyn Lander. Playing Companies and Commerce in Shakespeare's Time. Cambridge: Cambridge University Press, 2001.

—. The Repertory of Shakespeare's Company, 1594-1613. Fayetteville: University of Arkansas Press, 1991.

Levin, Richard. "More Jibes at Shakespeare in 1606, and the Date of Antony and Cleopatra." Notes and Queries 52, no. 2 (2005): 206-8.

Lipscomb, Robert. “Caesar's Same-Sex-Food-Sex Dilemma.” Early English Studies 2 (2009): 1-13.

Logan, Robert A. "Edward II." In Christopher Marlowe at 450, edited by Sara Munson Deats and Robert A. Logan, pp. 125-44. Burlington: Ashgate, 2015.

- "'High events as these': Sources, Influences, and the Artistry of Antony and Cleopatra." In "Antony and Cleopatra": New Critical Essays, edited by Sara Munson Deats, pp. 153-74. New York: Routledge, 2005.

- Shakespeare's Marlowe: The Influence of Christopher Marlowe on Shakespeare's Artistry. Aldershot: Ashgate, 2007.

—. "The Sexual Attitudes of Marlowe and Shakespeare." University of Hartford Studies in Literature 19, no. 2/3 (1987): 1-23.

—. "Violence, Terrorism, and War in Marlowe's Tamburlaine Plays." In War and Words: Horrors and Hallelujahs, edited by Sara Munson Deats, Lagretta Tallent Lenker, and Merry G. Perry, pp. 65-81. Lanham, MA: Rowman and Littlefield, 2004.

MacDonald, Ronald R. "Playing Till Doomsday: Interpreting Antony and Cleopatra." English Literary Renaissance 15 (1985): 78-99.

Mack, Maynard, ed. Antony and Cleopatra. Baltimore: Penguin Books, 1960. 
Madelaine, Richard. "Recent Responses to Antony and Cleopatra." The Shakespearean International Yearbook: Where Are We Now in Shakespearean Studies? 2 (2002): 47-62.

Manley, Lawrence and Sally-Beth MacLean. Lord Strange's Men and Their Plays. New Haven, CT: Yale University Press, 2014.

Markels, Julian. The Pillar of the World: "Antony and Cleopatra" in Shakespeare's Development. Columbus: Ohio State University Press, 1968.

Marlowe, Christopher. Christopher Marlowe: The Complete Plays. Edited by Mark Thornton Burnett. London: M. M. Dent, 1999.

Marshall, Cynthia. "Man of Steel Done Got the Blues: Melancholic Subversion of Presence in Antony and Cleopatra." Shakespeare Quarterly 44, no. 4 (1993): 385-408.

Marshall, P. David. The Celebrity Culture Reader. New York: Routledge, 2006.

Maus, Katherine Eisaman. Inwardness and Theatre in the English Renaissance. Chicago: University of Chicago Press, 1995.

McDonald, Russ. Shakespeare's Late Style. Cambridge: Cambridge University Press, 2006.

- The Bedford Companion to Shakespeare: An Introduction with Documents. 2nd ed. Boston: Bedford/St Martin's, 2001.

McKerrow, R. B., ed. The Works of Thomas Nashe. 5 vols. London: A. H. Bullen, 1904-10. Revised by F. P. Wilson. Oxford: Basil Blackwell, 1966.

Milton, John. John Milton: Complete Poems and Major Prose. Edited by Merritt Y. Hughes. Indianapolis: Odyssey Press, 1957.

Muir, Kenneth. "The imagery of Antony and Cleopatra." Kwartalnik Neofilologiczny 8 (1961): 247-64.

Neill, Michael. Issues of Death: Mortality and Identity in English Renaissance Tragedy. Oxford: Oxford University Press, 1997.

Oates, Joyce Carol. "The Tragedy of Imagination in Antony and Cleopatra." In Living With Shakespeare, edited by Susannah Carson, pp. 418-32. New York: Vintage Books (Random House), 2013.

Orgel, Stephen and A. R. Braunmuller, gen. ed. William Shakespeare: The Complete Works. New York: Penguin Putnam, 2002.

Parolin, Peter A. "Cloyless Sauce': The Pleasurable Politics of Food in Antony and Cleopatra." In "Antony and Cleopatra": New Critical Essays, edited by Sara Munson Deats, pp. 213-229. New York: Routledge, 2005.

Pope, Alexander. Poetry and Prose of Alexander Pope. Edited by Aubrey Williams. Boston: Houghton Mifflin, 1969.

Rabkin, Norman. Shakespeare and the Common Understanding. New York: Free Press, 1967.

- Shakespeare and the Problem of Meaning. Chicago: University of Chicago Press, 1981.

Roach, Joseph. "Celebrity Culture and the Problem of Biography." Shakespeare Quarterly 65, no. 4 (2014): 470-81. 
- It. Ann Arbor: University of Michigan Press, 2007. “The Doubting Thomas Effect." PMLA 126, no. 4 (2011): 1127-30.

Rojek, Chris. Celebrity. London: Reaktion Books, 2001.

Rose, Mark, ed. and intro. Twentieth Century Interpretations of "Antony and Cleopatra": A Collection of Critical Essays. Englewood Cliffs, NJ: PrenticeHall, 1977.

Rosenberg, Marvin (edited and completed by Mary Rosenberg). The Masks of Anthony and Cleopatra. Newark: University of Delaware Press, 2006.

Royster, Francesca T. Becoming Cleopatra: The Shifting Image of an Icon. New York: Palgrave Macmillan, 2003.

Rutter, Tom. "Adult Playing Companies: 1603-1613." In The Oxford Handbook of Early Modern Theatre, edited by Richard Dutton, pp. 72-87. Oxford: Oxford University Press, 2009.

Sandler, Robert, ed. Northrop Frye on Shakespeare. Markham, ON: Fitzhenry \& Whiteside, 1986.

Schalkwyk, David. "Is Love an Emotion? Shakespeare's Twelfth Night and Antony and Cleopatra." symploke 18, no. 1/2 (2010): 99-130.

Schiff, Stacy. Cleopatra: A Life. New York: Little, Brown, 2010.

Schmidt, Alexander. Shakespeare's Lexicon. 3rd ed. Revised and enlarged by Gregor Sarrazin. New York: Benjamin Blom, 1968.

Schoenbaum, Samuel. William Shakespeare: A Compact Documentary Life. Oxford: Oxford University Press, 1977.

Shackford, Martha Hale. Plutarch in Renaissance England with Special Reference to Shakespeare. Wellesley: Wellesley College, 1929.

Shakespeare, William. William Shakespeare: The Complete Works. Edited by Stephen Orgel and A. R. Braunmuller. The New Pelican Text. New York: Penguin Putnam, 2002.

Shapiro, James. The Year of Lear: Shakespeare in 1606. New York: Simon \& Schuster, 2015.

Sidney, Sir Philip. “An Apology For Poetry” (1595). In The Golden Hind. Revised edition by Roy Lamson and Hallett Smith, p. 285. New York: W. W. Norton, 1956.

Siemon, James R. Shakespearean Iconoclasm. Berkeley: University of California Press, 1985.

- Word Against Word: Shakespearean Utterance. Amherst and Boston: University of Massachusetts Press, 2002.

Simmons, J. L. Shakespeare's Pagan World: The Roman Tragedies. Charlottesville: University of Virginia Press, 1973.

Skiena, Steven and Charles B. Ward. Who's Bigger: Where Historical Figures Really Rank. Cambridge: Cambridge University Press, 2014.

Spencer, Theodore. Death and Elizabethan Tragedy. New York: Pageant Books, 1960. 
Spenser, Edmund. The Complete Poetical Works of Spenser. Edited by R. E. Neil Dodge. Boston: Houghton Mifflin, Riverside Press, 1908.

Spevack, Martin. A New Variorum Edition of Shakespeare: "Antony and Cleopatra." New York: Modern Association of America, 1990.

Syme, Holger Schott. "The Meaning of Success: Stories of 1594 and Its Aftermath.” Shakespeare Quarterly 61, no. 4 (2010): 490-525.

Taylor, Gary. Reinventing Shakespeare: A Cultural History from the Restoration to the Present. London: The Hogarth Press, 1990.

Waith, Eugene M. Ideas of Greatness: Heroic Drama in England. London: Routledge \& Kegan Paul, 1971.

- The Herculean Hero in Marlowe, Chapman, Shakespeare and Dryden. New York: Columbia University Press, 1962.

Wilson, John Dover, ed. The Works of Shakespeare: "Antony and Cleopatra." Cambridge Shakespeare edition. Cambridge: Cambridge University Press, 1950.

Wofford, Susanne L. "Antony's Egyptian Bacchanals: Heroic and Divine Impersonation in Shakespeare's Plutarch and Antony and Cleopatra." Poetica: An International Journal of Linguistic-Literary Studies 48 (1997): 33-67.

Worthen, W. B. "The Weight of Antony: Staging 'Character' in Antony and Cleopatra." Studies in English Literature 1500-1900 26, no. 2 (1986): 295-308.

Yoshino, Kenji. A Thousand Times More Fair: What Shakespeare's Plays Teach Us About Justice. New York: Ecco/HarperCollins, 2011. 



\section{Index}

All play characters in the index are from Antony and Cleopatra, except where indicated. For example, Lepidus, and Lepidus $(J C)$; the former is from Antony and Cleopatra, while the latter is from Julius Caesar.

Actium, battle, 34, 57, 93, 104, 112 actors

audiences, relationship, 35

celebrity status, 34-35

Adelman, Janet, 97-98

Aeneas and Dido, 128-29, 151n2, 180 n 37

aesthetics and the imagination, 142-43

Agrippa, 22, 135

Alexandria, 46

Alexas, 46

Alleyn, Edward, celebrity status, 35, $48 \mathrm{n} 14$

ambiguities

in Antony and Cleopatra, 4, 5, 12, 56, 57, 65, 68, 75, 87, 97, 105, $109,112,114,129$

dramatic purposes of, 175

and the imagination, 175

in Marlowe's works, 151n3, 162, 175

of Soothsayer's presence, 7-8

Antony, 12

afterlife, contemplation of,

128-29

bountiful nature, 113

death, 26, 74 contemplation of, 127

Dercetus on, 134-35

Octavius on, 134

devotion, inspirer of, 172, 175

Enobarbus on, 94, 99, 110

Eros, speech to, 129

euphoria, 115-16

fame, 38-40, 57-58, 59, 78, 85,

119

fate, acceptance of, 131

impulsiveness, 54

Maecenas on, 135

measuring up, 54, 55, 57-58, 66,

$67,71,76,78$

failure in, 81

misjudgments, 96

moralistic criticism of, 66

oratory, 126

Philo on, 66-69, 73

values, 102, 107-8

Antony and Cleopatra

afterlife references, 19

ambiguities in, 4, 5, 12, 56, 57, 65, $68,75,87,97,105,109,112$,

$114,129,175$

approaches to, 5

autonomy, 45-46

characterizations, 11-12 
Coleridge on, 114

composition date, 17

criticism of, 1

expansiveness, 65

external challenges, 53

fame, 1, 36-37, 38-40, 171

first performance date, $17-18$

inner challenges, 53

linguistic inventiveness, 26, 79-80, $114,117,119,126$

love versus duty trope, 22, 34, $48 \mathrm{n} 11$

measuring up, 54-55

perceptual contrasts, 101

Roman values in, 23

sources and influences, 21

in Stationers' Register, 17

transcendence of time, 33-34

Antony and Cleopatra

autonomy, 173, 174

as celebrities, $40,62,177 \mathrm{n} 2$

culture clash, 54

denunciatory perspective, $31,47 \mathrm{n} 1$

fame, 34, 36, 41, 46, 47, 96, 109, 174

gender roles, flexibility, 115

legend of, 40

measuring up, 70-71, 96, 129, 176

Octavius on, 108

Shakespeare's precursors, 31, 47n2

Spenser on, 66

transcendence of ordinariness, 173

"apprehending," and "comprehending,

states of mind, 5-6, 96-97

Armin, Robert, 25, 49n16

audience participation, Shakespearean, 16 n 19

audiences, actors, relationship, 35

autonomy

Antony and Cleopatra, 45-46

Antony and Cleopatra's, 173, 174

Shakespeare's, 44-45, 174, 180n37
Bancroft, Thomas, 165

"Bardolatry," 170-71

Barnes, Barnabe, The Devil's Charter, 17

Basse, William, 164

Blount, Edward, 17

Bottom (MND), 44

Branagh, Kenneth, 159, 160

Braudy, Leo, The Frenzy of Renown:

Fame \& Its History, 40-41

Burbage, Richard, 35

Burton, Richard, 40

Calderwood, James, 26

Capulet, Lady (Rom.), 10

Capulet, Lord (Rom.), 10-11

celebrities

actors as, 34-35

Antony and Cleopatra as, 40, 62, $117 \mathrm{n} 2$

highbrow versus lowbrow, 37-38

See also famous people

celebrity

earliest use of term, 37

fame, distinction, 37-38

Shakespeare as, 155, 159, 170

censorship, 20, 25, 29n5

Cerasano, S.P., 24, 25

on celebrity, 34-35

"Edward Alleyn, the New Model

Actor, and the Rise of the Celeb-

rity in the 1590 s," 34

change

constant, 100-101

and paradigms of fame, 176

and perspective, 101

characters

authorial (metadramatic), 9-10

death, attitude to, 27

functional, 8-9

realistic, 6-7, 134

representational, $7-8,134$

types, 6-10 
Charmian, 77, 130, 146, 148 death, 149

measuring up, 75-76, 149

moralizing, 126

Charnes, Linda, 40, 41, 85

on "Bardolatry," 170-71

Chernaik, Warren, The Myth of

Rome in Shakespeare and His

Contemporaries, 23

Chettle, Henry, 163

Cinna $(J C), 23$

Cleopatra, 9, 12, 22, 45

on Antony's fame, 38-40, 60

Enobarbus' praise of, 63-64, 77

fame, 77, 116, 133, 145, 172

and Shakespeare's, 176

linguistic characteristics, 176

measuring up, 54, 55, 77, 107, 133,

$140,144,145,147,148-49,150$

misjudgments, 96

self-deception, 173

suicide, $27,74,86,106-7,136,137$,

144-45

contemptus mundi, 147

and the imagination, 143

perspectives, 147-48

traits, 110

wealth, 138-39

Clown, 25, 143, 144

Coleridge, Samuel Taylor, on Antony and Cleopatra, 114 praise of Shakespeare, 168-69

Condell, Henry, 164

Coriolanus, 7, 18, 142

Cymbeline, 18, 23

Danby, John, 8-9, 75

Daniel, Samuel, Cleopatra, 17

Davenant, William, Sir, 165

Deats, Sara Munson, Antony and Cleopatra: New Critical Essays, $1-2,4$

Demetrius, 41, 73
Dercetus, on death of Antony, 134-35

Dido. See Aeneas and Dido

Dolabella, 27, 37, 38, 64, 120, 138

Drayton, Michael, Battaile of Agincourt, 165

drinking, Octavius on, 110-11

See also food and drink

Dryden, John, All for Love, 166

An Essay of Dramatic Poesy, 166

Shakespeare

adaptations of, 166

praise of, 166

Eliot, T.S., 42

Enobarbus, 7, 8, 9, 22, 26, 34, 57, 76, 86

on Antony, 94, 99, 110

death, 27, 61, 74, 120

measuring up, 55, 61

praise of Cleopatra, 63, 64, 77

Eros, Antony's speech to, 129

Esler, Anthony, 86

The aspiring mind of the Elizabethan younger generation, 82

Falstaff (1H4), 86, 103

fame,

acquisition of, 41, 85

in Antony and Cleopatra, 1, 36-37, 38-40, 171

Antony and Cleopatra's, 34, 36, 41, 46, 47, 96, 109, 174

Antony's, 38-40, 57-58, 59, 78, 85, 119

Cleopatra on, 38-40, 60 search for, 57-58

celebrity, distinction, 37-38

and cheating death, 32-33

Cleopatra's, 77, 116, 133, 145, 172

criterion for, 40

and honor, 86

and the imagination, 131 
fame (cont.):

and legend, 40

literary studies of, 2

and loyalty, 59-60

meaning, 36, 59

and measuring up, 55-56

and myth making, 158-59

Octavius's, 108-9

paradigms of, and change, 176

as process, 38

promotion of, and elevated language, 69-70

in Shakespeare, 36, 47

Shakespeare's, 164-65, 169-70,

171,174

and Cleopatra's, linked, 176

famous people,

devotion to, 42-43,

responses to, 41-42

as role models, 41-42

See also celebrities

Fate, role of, 118

film, Shakespeare's works on, 159-60, 178n 8

directors, 159-60

First Folio Edition (1623), 164, 165

See also Second Folio Edition

food, metaphor, 144

See also drinking; food and drink

food and drink, 109-13

metaphors, 111

and psychological states, 112

Forrest, Edwin, 170

Fortune, wheel of, 132

Fulvia, 7, 59, 71, 76

gender roles, Antony and Cleopatra, flexibility, 115

Giles, David 37, 38

Glendower (1H4), 20-21

Globe Theatre, 170

Greenblatt, Stephen, 44-45, 46
Will in the World: How Shakespeare Became Shakespeare, 158

Greene, Robert, criticism of

Shakespeare, 163

Greville, Fulke, Antony and Cleopatra, 21

Hamlet, 44, 157, 167

Hamlet (Ham.), 26, 40, 42

Hanmer, Thomas, 167

Hemings, John, 164

Henry IV, Part 1, 20

Henry IV, Part 2, 22

Henslowe, Philip, 164

Hercules, 113

Hester and Ahasuerus, 22

Hippolyta (MND), 9, 10

honor,

in Antony and Cleopatra, 82-83

and fame, 86

Hotspur's (1H4), 86

as measure of greatness, $83-84$

notion of, 82

Pompey on, 84

and power politics, $84-85$

Hotspur (1H4), honor, 86

idealizations, 114

identity, establishing, 63

imagination, and aesthetics, 142-43

and ambiguities, 175

and Cleopatra's suicide, 143

and fame, 131

and realism, 64

Roman lack of, 141

and self-deception, 97

Shakespeare's concern with, $153 \mathrm{n} 17$

Iras, 45, 46, 140-41

death, 146

Johnson, Samuel, praise of

Shakespeare, 167-68 
Jonson, Ben, praise of Shakespeare, 165, 166

The Works of Benjamin Jonson, 164

Jorgenson, Paul, 21

Julius Caesar, 18, 23, 31, 142, 167

Julius Caesar, 27, 135-36, 138, 139

measuring up, 149-50

Kathman, William, 165

Keats, John, on Shakespeare's Negative Capability," 21, 169

Kempe, Will, 25, 49n16

King Lear, 8, 114

King's Men, 24

Kozintsev, Grigori, 159, 160

Kurasawa, Akira, 159, 160

Lady Elizabeth's Men, 24

legend, of Antony and Cleopatra, 40 definition, 40

Lepidus, 22, 79

Lepidus (JC), 23

Lord Admiral's Men, 35

love versus duty trope, 22, 34, 48n 11

loyalty, and fame, 59-60

Macbeth, 157

MacDonald, Ronald R., 56-57

McDonald, Russ, 168 Shakespeare's Late Style, 176

Macready, William Charles, 170

Maecenas, 9, 22 on Antony, 135

Malone, Edmond, 167

Mardian, 22

Markels, Julian, 55, 69

Marlowe, Christopher, 119 ambiguities in works, $15 \ln 3,162$, 175 influence on Shakespeare, 105, 162 innovations, 162 Tamburlaine, 162, 178n11 masques, 25

measuring up,

Antony, 54, 55, 57-8, 66, 67, 71, 76,78

Antony and Cleopatra, 70-71, 96, 129, 176

Antony and Cleopatra's love, 71-72

Charmian, 75-76, 149

Cleopatra, 54, 55, 77, 107, 133, $140,144,145,147,148-49$, 150

comic rendering of, 144

Enobarbus, 55

and fame, 55-56

humorous treatment of, 75

Julius Caesar, 149-50

Measure for Measure, 87

minor characters, 62

Octavius, 55

Pompey, 55, 94

psychological perspective, 88

references to, 87

Shakespeare, 176

standards, 56, 63, 64-65, 79, 86,

$115,132,143$

The Merchant of Venice, 157

Meres, Francis, 164, 165

A Midsummer Night's Dream, 5, 9, 43, 44, 96

accessibility, 157

Milton, John, praise of Shakespeare, 166

mind-body split, Cartesian, $121 \mathrm{n} 1$

Modena, battle, 110

Much Ado About Nothing, 8

myth, of Shakespeare, 161

myth making, and fame, 158-59

Nashe, Thomas, 163

"negative capability" (Keats)

meaning, 169

Shakespeare's, 21, 169

nouns, as verbs, $36,140,141$ 
Octavia, 8, 9, 11, 22, 55

Octavius, 8, 9, 12, 23, 26, 46, 78-79, 121

on Antony and Cleopatra, 108

on death of Antony, 134

fame, 108-9

measuring up, 55

moralizing, 79, 80, 103

Olivier, Laurence, 159-60

Ovid, 105

patronage system, 24, 25

Peele, George, The Turkish Mahomet and Hiren the Fair Greek, 22

Pericles, Prince of Tyre, 17

perspectives

aesthetic versus moral, 101-2, 103, 106, 107

changes in, 93-94, 94-95, 97-98, 99-101, 141-42

Cleopatra's suicide, 147-48

dramaturgical, 150

moral versus psychological, 101, 102, 103-6, 127

Shakespeare's perspective on, 98-101, 122n3

Peter Quince (MND), 44

Philo, 41, 59, 71 on Antony, 66-69, 73

Plutarch, 105, 152n 10

Polonius (Ham.), 44

Pompey

on honor, 84

measuring up, 55, 94

Pompey $(J C), 23$

Pope, Alexander, 167

Prince Henry's Men, 24

Proculeius, 9, 137, 137-38

Prospero (Tmp.), 44

public-private conflict, 61-62, 78, 146

Puck (MND), 44

Queen's Men, 24
The Rape of Lucrece, 18, 27, 156

realism, and imagination, 64

Richard II, 7, 31

Roach, Joseph, on celebrities, 32

Romans, lack of imagination, 141

Rome

Egypt cultural perspectives, 93, 119, $120,12 \ln 1$

value differences, 6-7, 90n25, $101,108,119,120$

Renaissance attitude to, 23

Shakespeare's attitude to, 23-24

Romeo and Juliet, 60, 157

Rose, Mark, 55

Rose Theatre, 35, 162, 164

Rosenberg, Marvin, The Masks of Anthony and Cleopatra, 1

Rowe, Nicholas, 167

Rutter, Tom, "Adult Playing Companies: 1603-1613," 24

Rymer, Thomas, 167

Sam Wanamaker Playhouse, 170

Scarus, 118-19

Schlegel, Auguste Wilhelm von, 168

Second Folio Edition (1632), 164, 165, 166

See also First Folio Edition (1623)

Seleucus, 138, 139

self-deception, and the imagination, 97

Shakespeare Quarterly, 4

Shakespeare, William adaptations of, 166-67

aesthetic autonomy, 44-45, 174, 180n37

ambiguities, use of, 129, 130

attitude to

death, 27-28

fame, 36, 47

history, 18

moralizing, 20, 29n4, 123n 12 
religion, 19

Rome, 23-24

as celebrity, 155, 159, 170

criticisms of, 167

devotion, inspirer of, 175

Dryden's adaptations, 166

editions of plays, 167

eulogies on, 164-66

fame of, 164-65, 169-70, 171,

174

and Cleopatra's, 176

films, 159-60, 178n8

directors, 159-60

Greene's criticism, 163

imagination, concern with, 153n 17

Marlowe's influence, 105

measuring up, 176

myth of, 161

"negative capability" (Keats), 21, 169

perspective on perspective, 98-101

popularity, 155-58

praise of,

Coleridge's, 168-69

contemporary, 163, 163-64

Dryden's, 166

Johnson's, 167-68

Jonson's, 165, 166

Milton's, 166

Roman writings, 18

self-glorification, 174

on television, 161

Sidney, Philip, Sir, "An Apology For Poetry," 32

Soothsayer, 54, 78, 113, 118, 120

ambiguities of presence, 7-8

Spenser, Edmund, on Antony and

Cleopatra, 66
Taylor, Elizabeth, 40

Taylor, John, 164

television, Shakespeare's works on, 161

The Tempest, 44, 166

theatre

companies, 24

early modern, economic stability, 24

repertories, 24-25

as safe place for political topics, 142

Theobald, Lewis, 167

Theseus (MND), 9-10, 10, 44, 96

Thidias, 23, 59, 64

time, transcendence of, $117,118,120$, 121

in Antony and Cleopatra, 33-34

Titus Andronicus, 18, 23, 31

Troilus and Cressida, 166

values,

Antony's, 102, 107-8

As You Like It, 102-3

King Lear, 103

Othello, 103

public versus private, $129,180 \mathrm{n} 37$

Roman, 23, 58, 107, 108

Roman versus Egyptian, 6-7,

90n25, 101, 108, 119, 120

Venus and Adonis, 21, 27, 156

verbs, nouns as, 36, 140, 141

Voltaire, 167

Wanamaker, Sam, 170

Warburton, William, 167

Welles, Orson, 159, 160

Zeffirelli, Franco, 159, 160 